UNIVERSIDADE DE SÃO PAULO

ESCOLA POLITÉCNICA

DEPARTAMENTO DE ENGENHARIA QUÍMICA

HELENA PLETSCH

Seleção e isolamento de bactérias fixadoras de $\mathrm{CO}_{2}$ para a purificação de gases de combustão e de gás natural

São Paulo 


\section{HELENA PLETSCH}

Seleção e isolamento de bactérias fixadoras de $\mathrm{CO}_{2}$ para purificação de gases de combustão e de gás natural

\section{Versão Corrigida}

Dissertação apresentada à Escola Politécnica da Universidade de São Paulo para obtenção do título de Mestre em Ciências.

Área de concentração: Engenharia Química

Orientador: Prof. Dr. Cláudio Augusto Oller do Nascimento

Co-orientador: Dr. Enrique E Rozas

São Paulo 
Autorizo a reprodução e divulgação total ou parcial deste trabalho, por qualquer meio convencional ou eletrônico, para fins de estudo e pesquisa, desde que citada a fonte.

Este exemplar foi revisado e corrigido em relação à versão original, sobresponsabilidade única do autor e com a anuência de seu orientador.

Assinatura

Aelena Pletech

Assinatura do orientador:

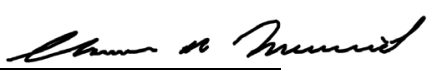

\section{Catalogação-na-publicação}

Pletsch, Helena

Seleção e isolamento de bactérias fixadoras de CO2 para a purificação de gases de combustão e de gás natural / H. Pletsch -- versão corr. -- São Paulo, 2021.

$122 \mathrm{p}$.

Dissertação (Mestrado) - Escola Politécnica da Universidade de São Paulo. Departamento de Engenharia Química.

1.Captura de carbono 2.Biofixação de $\mathrm{CO} 2$ 3.Gás natural e gases de exaustão 4.Bactérias quimioautotróficas 5.CO2 I.Universidade de São Paulo. Escola Politécnica. Departamento de Engenharia Química II.t. 
PLETSCH, H. Seleção e isolamento de bactérias fixadoras de $\mathrm{CO}_{2}$ para a purificação de gases de combustão e de gás natural. 2021. Dissertação (Mestrado em Engenharia Química) - Escola Politécnica, Universidade de São Paulo, São Paulo, 2021.

Aprovado em:

Banca Examinadora

Prof.(a) Dr.(a)

Instituição:

Julgamento:

Prof.(a) Dr.(a)

Instituição:

Julgamento:

Prof.(a) Dr.(a)

Instituição:

Julgamento: 
A minha família

e a todos os pesquisadores brasileiros. 


\section{AGRADECIMENTOS}

À minha família, por seu amor e apoio incondicional;

Ao meu orientador, Prof. Dr. Cláudio A. Oller do Nascimento, pela oportunidade e pela confiança a mim creditada;

Ao meu co-orientador, Dr. Enrique Rozas, que pacientemente contribuiu para o meu crescimento científico e intelectual.

À Dra. Maria Anita Mendes e à Dra. Meriellen Dias, por sempre estarem dispostas a me auxiliar;

Ao Prof. Dr. Arthur Ayres Neto (LAGEMAR-UFF), por gentilmente fornecer as amostras de sedimento antártico utilizadas no presente trabalho;

Aos colegas de laboratório, pela cumplicidade e pela ajuda;

Ao Departamento de Engenharia Química da Escola Politécnica da USP, pela oportunidade de realizar o curso de mestrado;

Ao Conselho Nacional de Desenvolvimento Científico e Tecnológico (CNPq) pelo apoio financeiro concedido. 
"Nothing in life is to be feared, it is only to be understood [...]."

(Marie Curie) 


\section{RESUMO}

\section{PLETSCH, H. Seleção e isolamento de bactérias fixadoras de $\mathrm{CO}_{2}$ para a purificação de}

gases de combustão e de gás natural. 2021. Dissertação (Mestrado em Engenharia Química) - Escola Politécnica, Universidade de São Paulo, São Paulo, 2021.

A crescente preocupação com o aquecimento global impulsionou o desenvolvimento de novas tecnologias para a captura e utilização de carbono (CCU). Esforços para combater as mudanças climáticas são especialmente necessários nas indústrias, que atualmente respondem por um terço das emissões mundiais de $\mathrm{CO}_{2}$. Neste contexto, os tradicionais processos industriais de captura de carbono vêm cedendo espaço para estratégias mais sustentáveis, tais como a fixação microbiológica de $\mathrm{CO}_{2}$. Apesar de promissoras, estas estratégias ainda exibem consideráveis problemas operacionais e maiores avanços na área são precisos. Assim, o presente trabalho visou investigar bactérias quimioautotróficas capazes de assimilar $\mathrm{CO}_{2}$ em condições semelhantes às encontradas industrialmente (e.g., gases de exaustão e gás natural). Como resultado, 7 cepas bacterianas capazes de crescer autotroficamente sob $20 \% \mathrm{CO}_{2}$ foram isoladas a partir de sedimentos marinhos antárticos. Uma das cepas isoladas, M1B-S, apresentou elevada capacidade de capturar carbono sob atmosferas contendo de 5 a $20 \% \mathrm{CO}_{2}$ e sob temperaturas de 30 a $50{ }^{\circ} \mathrm{C}$. A máxima taxa de fixação de $\mathrm{CO}_{2}$ por M1B-S foi observada em cultivos mantidos a $5 \% \mathrm{CO}_{2}$ e $30^{\circ} \mathrm{C}\left(308 \mathrm{mg}\right.$ de $\left.\mathrm{CO}_{2} / \mathrm{L} / \mathrm{d}\right)$. Esta bactéria foi identificada como membro do gênero Alcanivorax e mostrou ser capaz de obter energia a partir da oxidação de $\mathrm{S}_{2} \mathrm{O}_{3}{ }^{-2}$. Além disso, M1B-S também exibiu capacidade de reduzir íons $\mathrm{NO}_{3}{ }^{-}$e pode ser potencialmente utilizada para remover $\mathrm{CO}_{2}$ e $\mathrm{NO}_{\mathrm{x}}$ de gases de combustão e de gás natural. Até o presente momento, este trabalho é um dos primeiros a isolar, a partir de sedimentos marinhos antárticos, bactérias quimioautotróficas capazes de fixar $\mathrm{CO}_{2}$ em concentrações acima de 5\%. Ainda, é o primeiro a reportar crescimento autotrófico em uma espécie do gênero Alcanivorax.

Palavras-chave: $\mathrm{CO}_{2}$. Gases de combustão. Gás natural. Biofixação de carbono. Captura de carbono. Bactérias quimioautotróficas. Alcanivorax. 


\begin{abstract}
PLETSCH, H. Isolation and selection of $\mathbf{C O}_{2}$-fixing bacteria for the purification of flue gases and natural gas. 2021. Dissertação (Mestrado em Engenharia Química) - Escola Politécnica, Universidade de São Paulo, São Paulo, 2021.
\end{abstract}

Growing concerns about the global warming have stimulated the development of new technologies for carbon capture and utilization (CCU). Efforts to fight climate change are especially vital for industries, which currently contribute to over $30 \%$ of world's $\mathrm{CO}_{2}$ emissions. In this scenario, the traditional carbon capture processes are giving room to sustainable alternatives such as the microbiological fixation of $\mathrm{CO}_{2}$. Despite promising, these alternatives need further enhancements in order to be suitable for wide industrial application. Thus, this project aimed to study chemoautotrophic bacteria capable of assimilating $\mathrm{CO}_{2}$ under industry-relevant conditions, i.e., under the temperatures and $\mathrm{CO}_{2}$ concentrations of flue gases and natural gas. As a result, seven bacterial strains able to grow under $20 \% \mathrm{CO}_{2}$ were isolated from Antarctic marine sediments. One of the isolated strains, M1B-S, exhibited high carbon fixation capacities under concentration of 5 to $20 \% \mathrm{CO}_{2}$ and temperatures of 30 to $50^{\circ} \mathrm{C}$. Maxima $\mathrm{CO}_{2}$ fixation rates were observed in cultivations of $\mathrm{M} 1 \mathrm{~B}-\mathrm{S}$ at $30^{\circ} \mathrm{C}$ and $5 \% \mathrm{CO}_{2}(308$ $\mathrm{mg}$ of $\left.\mathrm{CO}_{2} / \mathrm{L} / \mathrm{d}\right)$. Moreover, the results indicated that M1B-S belongs to the genus Alcanivorax and that it consumes $\mathrm{S}_{2} \mathrm{O}_{3}{ }^{-2}$ as an energy source. Yet, this strain is also capable of reducing $\mathrm{NO}_{3}{ }^{-}$and could be potentially used to remove both $\mathrm{CO}_{2}$ and $\mathrm{NO}_{\mathrm{x}}$ from flue gas and natural gas. Until now, this work is one of the first to isolate, from Antarctic marine sediments, chemoautotrophic bacteria capable of fixing carbon under high $\mathrm{CO}_{2}$ concentrations $(>5 \%)$. I is also the first to report chemoautotrophic growth of an Alcanivorax species.

Keywords: $\mathrm{CO}_{2}$. Flue gas. Natural gas. Carbon biofixation. Carbon capture. Chemoautotrophic bacteria. Temperature. Alcanivorax. 


\section{LISTA DE FIGURAS}

Figura 1- Séries temporais da variação na temperatura média do planeta (vermelho) e da emissão total de GEEs (preto) entre os anos de 1850 e 2018.

Figura 2 - Ranking dos 10 países com maiores emissões de $\mathrm{CO}_{2}$ em 2017. Não foram

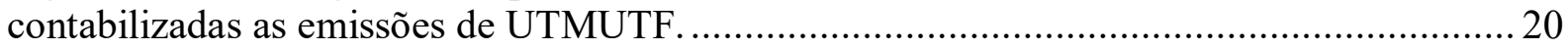

Figura 3 - Cenário brasileiro de emissões de GEEs por setor para o ano de 2018 ................. 21

Figura 4 - Fluxograma de um processo de oxi-combustão............................................... 27

Figura 5 - Fluxograma de um processo de pré-combustão................................................ 28

Figura 6 - Fluxograma de processo de absorção de $\mathrm{CO}_{2}$. ..................................................29

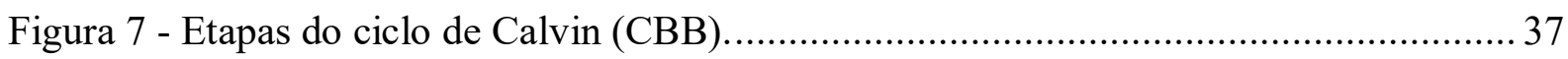

Figura 8 - Etapas do ciclo redutivo do ácido tricarboxílico (rTCA)..................................... 38

Figura 9 - Etapas da rota Wood-Ljungdahl ou rota redutiva do acetil-CoA. ......................... 39

Figura 10 - Ciclo do 3-hydroxypropionato/4-hidroxibutirato (3HP-4HB) ......................... 40

Figura 11 - Ciclo do dicarboxilato/4-hidroxibutirato........................................................ 41

Figura 12 - Bi-ciclo do 3-hidroxipropionato................................................................ 42

Figura 13 - Fluxograma resumindo a metodologia desenvolvida no presente trabalho.......... 46

Figura 14 - Ponto de coleta do sedimento utilizado para o isolamento bacteriano................ 47

Figura 15 - Etapas do enriquecimento seletivo primário de bactérias resistentes a elevadas

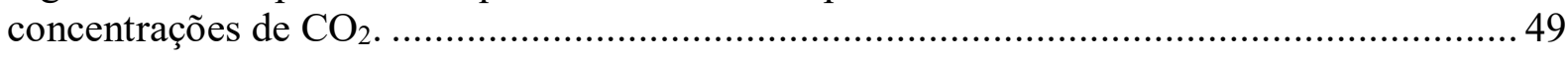

Figura 16 - Etapas do processo de seleção e cultivo de bactérias quimioautotróficas a partir das cepas isoladas no processo de enriquecimento de bactérias resistentes ao $\mathrm{CO}_{2 .} \ldots \ldots \ldots \ldots \ldots \ldots . . .52$

Figura 17 - Cepas com morfologias distintas, espalhadas em placas de BHI. ..................... 63

Figura 18 - Espectros de massa e perfis eletroforéticos das proteínas extraídas das bactérias do

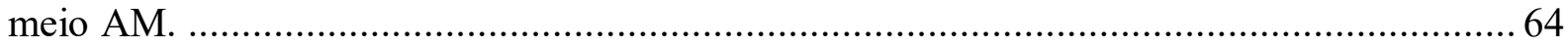

Figura 19 - Curvas de crescimento das colônias quimioautotróficas selecionadas.. .............. 68

Figura 20 -Crescimento da cepa AS3A sob atmosfera de ar e $\mathrm{CO}_{2}(20 \%)$.........................69

Figura 21 - Dendograma filogenético gerado com a ferramenta BLAST e baseado na sequência parcial do gene 16S rRNA (16S rDNA) da cepa M1B-S................................................... 72

Figura 22 - Curvas de crescimento da cepa M1B-S quando cultivada sob diferentes

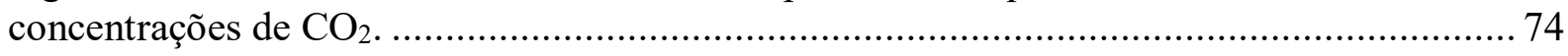

Figura 23 - Comparação da quantidade de $\mathrm{CO}_{2}$ fixada pela cepa M1B-S quando cultivada em bateladas submetidas a atmosferas com diferentes concentrações de $\mathrm{CO}_{2}\left(1 \mathrm{~atm}, 30^{\circ} \mathrm{C}\right) \ldots \ldots .75$

Figura 24 - Comparação entre o a) máximo rendimento em biomassa $\left(\mathrm{X}_{\text {máx }}\right)$ e b) máxima fixação de carbono inorgânico $\left(\mathrm{F}_{\mathrm{CO} 2 \text {,máx }}\right)$ para os cultivos da cepa M1B-S sob diferentes concentrações de $\mathrm{CO}_{2}$. 
Figura 25 -a) produtividade em biomassa $\left(\mathrm{P}_{\mathrm{b}}\right)$ e b) taxa de fixação de $\mathrm{CO}_{2}\left(\mathrm{~T}_{\mathrm{CO} 2}\right)$ da cepa M1B$\mathrm{S}$ quando cultivada em batelada e sob diferentes concentrações de $\mathrm{CO}_{2}\left(5 \%, 10 \%\right.$ e $20 \% \mathrm{CO}_{2}$ $\left.\mathrm{v} / \mathrm{v}, 1 \mathrm{~atm}, 30^{\circ} \mathrm{C}\right)$.

Figura 26 - a) produtividade máxima em biomassa $\left(\mathrm{P}_{\mathrm{b} \text {,máx }}\right)$ e b) taxa máxima de fixação de $\mathrm{CO}_{2}$ $\left(\mathrm{T}_{\mathrm{CO} 2, \text { máx }}\right)$ da cepa M1B-S quando cultivada em batelada e sob diferentes concentrações de $\mathrm{CO}_{2}$ (1 atm, $\left.30^{\circ} \mathrm{C}\right)$.

Figura 27 - Curvas de crescimento da cepa M1B-S a $30^{\circ} \mathrm{C}, 40^{\circ} \mathrm{C}$ e $50^{\circ} \mathrm{C}\left(\mathrm{p}_{\mathrm{CO} 2}=0,1 \mathrm{~atm}\right)$. Crescimento em termos de a) densidade ótica $\left(\mathrm{DO}_{600 \mathrm{~nm}}\right)$ e de b) biomassa $(\mathrm{X}, \mathrm{g} / \mathrm{L})$. .

Figura 28 - Quantidade de $\mathrm{CO}_{2}$ fixada em biomassa pela cepa M1B-S a diferentes temperaturas $\left(30^{\circ} \mathrm{C}, 40^{\circ} \mathrm{C}\right.$ e $\left.50^{\circ} \mathrm{C}\right)$.

Figura 29 - Etapas da formação de biofilme em cultivos quimioautotróficos da cepa M1B-S a $50^{\circ} \mathrm{C}$ e $\mathrm{p}_{\mathrm{CO} 2}=0,1 \mathrm{~atm}$.

Figura $30-$ a) rendimento máximo em biomassa e b) quantidade máxima de $\mathrm{CO}_{2}$ fixada pela cepa M1B-S quando cultivada sob diferentes temperaturas.

Figura 31 - a) produtividades em biomassa $\left(\mathrm{P}_{\mathrm{b}}, \mathrm{mg} / \mathrm{L} / \mathrm{d}\right)$ e b) taxas de fixação de $\mathrm{CO}_{2}$ em biomassa $\left(\mathrm{T}_{\mathrm{CO} 2}, \mathrm{mg} / \mathrm{L} / \mathrm{d}\right)$ obtidos durante 10 dias de cultivo de $\mathrm{M} 1 \mathrm{~B}-\mathrm{S}$ a $30^{\circ} \mathrm{C}, 40^{\circ} \mathrm{C}$ e $50^{\circ} \mathrm{C}(10$ $\left.\% \mathrm{CO}_{2}, 1 \mathrm{~atm}\right)$.

Figura 32 - a) produtividades máximas em biomassa $\left(\mathrm{P}_{\mathrm{b} \text { máx, }} \mathrm{g} / \mathrm{L} / \mathrm{d}\right)$ e b) taxas máximas de fixação de $\mathrm{CO}_{2}$ em biomassa $\left(\mathrm{T}_{\mathrm{CO} 2 \text {,máx }}, \mathrm{mg} / \mathrm{L} / \mathrm{d}\right.$ ) obtidos nos cultivos de $\mathrm{M} 1 \mathrm{~B}-\mathrm{S}$ a $30^{\circ} \mathrm{C}, 40^{\circ} \mathrm{C}$ e $50^{\circ} \mathrm{C}\left(10 \% \mathrm{CO}_{2}, 1 \mathrm{~atm}\right)$.

Figura 33 - Concentração de íons tiossulfato $\left(\mathrm{S}_{2} \mathrm{O}_{3}{ }^{-2}\right)$ e sulfato $\left(\mathrm{SO}_{4}^{-2}\right)$ durante o crescimento da cepa M1B-S sob $20 \% \mathrm{CO}_{2}$.

Figura 34 - Regressão linear da curva de massa seca (X, g/L) em função da densidade ótica (DO) para a cepa M1B-S. 106

Figura 35 - Espectros de massa e perfis eletroforéticos das proteínas extraídas das bactérias do meio ASM..

Figura 36 - Comparação entre as listas de picos obtidos para os espectros das cepas AS3C (verde), AS3B (laranja), AS3A (roxo), AS3D (azul) e ASA1B (vermelho).. 108

Figura 37 - Comparação entre as listas de picos obtidos para os espectros das cepas AM2A, $\mathrm{AM} 2 \mathrm{~B}$ e $\mathrm{AM} 2 \mathrm{C}$.

Figura 38 - Espectros peptídicos normalizados e perfis eletroforéticos das quatro cepas isoladas a partir do meio SM.

Figura 39 - Comparação entre as listas de picos obtidos para os espectros das cepas SM1A, SM1B, SM1C e SM2A.

Figura 40 - Espectros de massa normalizados e perfis eletroforéticos das proteínas extraídas a partir das três cepas isoladas do meio de cultura MM.

Figura 41 - Comparação entre as listas de picos obtidos para os espectros das cepas M1A, M1B e M1C.

Figura 42 - Espectros peptídicos normalizados e perfis eletroforéticos das cepas isoladas a partir do cultivo de M1A-S.

Figura 44 - Curvas de crescimento a diferentes concentrações de $\mathrm{CO}_{2}$ (1 atm) ajustadas pelos modelos Gompertz Modificado, Logístico Modificado, Potência Modificado e linear. 
Figura 45 - Curvas de crescimento a diferentes temperaturas ajustadas pelos modelos Gompertz Modificado, Logístico Modificado, Potência Modificado e linear.

Figura 46 - Velocidades máximas de crescimento ( $\mu_{\text {máx }}$ ) obtidas para a cepa M1B-S quando cultivada sob diferentes concentrações de $\mathrm{CO}_{2}\left(5 \%, 10 \%\right.$ e $\left.20 \% \mathrm{CO}_{2}\right)$.

Figura 47 - Velocidades máximas de crescimento ( $\left.\mu_{\text {máx }}\right)$ obtidas para a cepa M1B-S quando cultivada a $10 \% \mathrm{CO}_{2}(1 \mathrm{~atm})$ e sob diferentes temperaturas $\left(30^{\circ} \mathrm{C}, 40^{\circ} \mathrm{C}\right.$ e $\left.50^{\circ} \mathrm{C}\right) \ldots \ldots \ldots \ldots . . .117$

Figura 48 - a) Variação no $\mathrm{pH}$ do meio de cultura durante o crescimento da cepa M1B-S sob $10 \% \mathrm{CO}_{2}$

Figura 49 - Resultados dos testes colorimétricos para a detecção de íons $\mathrm{NO}_{3}{ }^{-}$e $\mathrm{NO}_{2}{ }^{-}$no meio de cultua da bactéria M1B-S. 


\section{LISTA DE TABELAS}

Tabela 1- Teor de carbono e contaminantes presentes nos gases de exaustão provenientes da

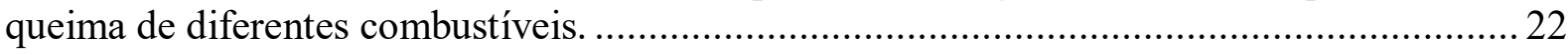

Tabela 2 - Principais fontes de emissões de $\mathrm{CO}_{2}$ em uma refinaria de petróleo.....................2 23

Tabela 3 - Mecanismos de fixação de $\mathrm{CO}_{2}$ em bactérias quimioautotróficas e as principais enzimas e precursores envolvidos em cada um destes caminhos.

Tabela 4 - Composição e fontes de energia dos quatro meios de cultura utilizados para o enriquecimento seletivo de bactérias tolerantes a elevadas concentrações de $\mathrm{CO}_{2} \ldots \ldots \ldots \ldots \ldots \ldots . \ldots 0$

Tabela 5 - Composição dos meios utilizados na seleção de cepas quimioautotróficas........... 53

Tabela 6 - Genes amplificados e primes utilizados no presente estudo. ..............................55

Tabela 7 - Modelos utilizados para descrever a curva de crescimento e obter o parâmetro de velocidade máxima de crescimento $\left(\mu_{\text {máx }}\right)$.

Tabela 8 - Resultados do isolamento bacteriano realizado a partir de sedimento marinho antártico.

Tabela 9 -Cepas quimioautotróficas selecionadas após 7 dias de cultivo no escuro, em meio mineral e sob $20 \% \mathrm{CO}_{2}$.

Tabela 10 - Parâmetros cinéticos de crescimento e características das cepas quimioautotróficas cultivadas sob $20 \% \mathrm{CO}_{2}$ e em diferentes meios de cultura minerais.

Tabela 11 - Similaridades da sequência de 16S rDNA parcial entre a cepa M1B-S e bactérias de referência.

Tabela 12 -Parâmetro $\mu_{\text {máx }}$ (intervalo de confiança assimétrico de 95\%) obtido em diferentes concentrações de $\mathrm{CO}_{2}$

Tabela 13 - Velocidades máximas de crescimento $\left(\mu_{\text {máx }}\right)$, máxima biomassa $\left(\mathrm{X}_{\text {máx }}\right)$, quantidade máxima de $\mathrm{CO}_{2}$ fixado $\left(\mathrm{F}_{\mathrm{CO} 2 \text {,máx }}\right)$, máxima produtividade de biomassa $\left(\mathrm{P}_{\mathrm{b} \text {,máx }}\right)$ e máxima taxa de fixação de $\mathrm{CO}_{2}\left(\mathrm{~T}_{\mathrm{CO} 2 \text {,máx }}\right)$ obtidas nos cultivos de M1B-S sob diferentes concentrações de $\mathrm{CO}_{2}$ (médias $\pm \mathrm{SD}$ ).

Tabela 14 - Parâmetros $\mu_{\text {máx }}$ (intervalo de confiança assimétrico de 95\%) obtidos a diferentes temperaturas de cultivo.

Tabela 15 - Velocidades máximas de crescimento $\left(\mu_{\text {máx }}\right)$, máxima biomassa $\left(\mathrm{X}_{\text {máx }}\right)$, quantidade máxima de $\mathrm{CO}_{2}$ fixado $\left(\mathrm{F}_{\mathrm{CO} 2 \text {,máx }}\right)$, máxima produtividade de biomassa $\left(\mathrm{P}_{\mathrm{b} \text {,máx }}\right)$ e máxima taxa de fixação de $\mathrm{CO}_{2}\left(\mathrm{~T}_{\mathrm{CO} 2 \text {,máx }}\right)$ obtidas nos cultivos de M1B-S sob diferentes temperaturas (médias $\pm \mathrm{SD}$ )

Tabela 16 - Resultados da análise de carbono orgânico total (TOC) do meio de cultura (TOC $\left.\mathrm{mc}_{\mathrm{mc}}\right)$ e das suspensões bacterianas $\left(\mathrm{TOC}_{\mathrm{sb}}\right)$.

Tabela 17 - Teste de comparação múltipla Games-Howell entre as velocidades específicas máximas de crescimento ( $\left.\mu_{\text {máx }}\right)$ a diferentes concentrações de $\mathrm{CO}_{2}$

Tabela 18 - Teste de comparação múltipla Games-Howell entre as velocidades específicas máximas de crescimento $\left(\mu_{\text {máx }}\right)$ a diferentes temperaturas. 


\section{SUMÁRIO}

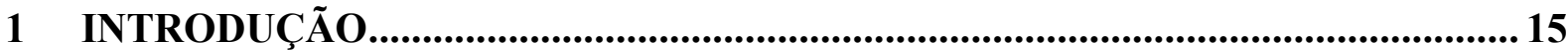

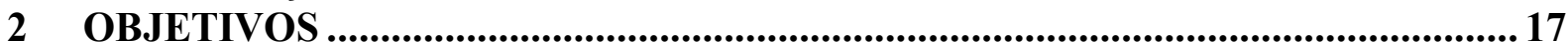

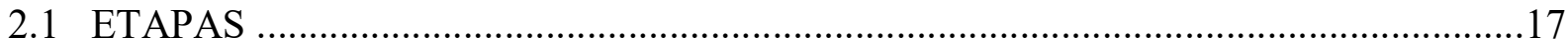

3 REVISÃO DA LITERATURA.......................................................................... 18

3.1 EMISSÕES DE $\mathrm{CO}_{2}$ E O AQUECIMENTO GLOBAL .............................................. 18

3.1.1 Principais fontes de emissão de $\mathrm{CO}_{2}$ e o cenário mundial ........................................ 19

3.1.2 Uso industrial de combustíveis fósseis e a produção de gases de exaustão ...............21

3.1.3 Emissões de $\mathrm{CO}_{2}$ na indústria de petróleo e gás.................................................22

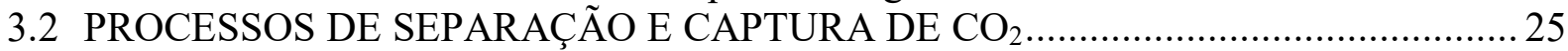

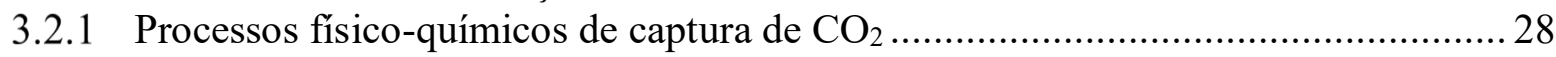

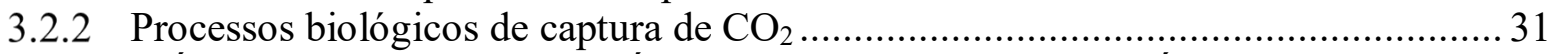

3.3 BACTÉRIAS QUIMIOAUTOTRÓFICAS E A FIXAÇÃO BIOLÓGICA DE $\mathrm{CO}_{2} \ldots . . .34$

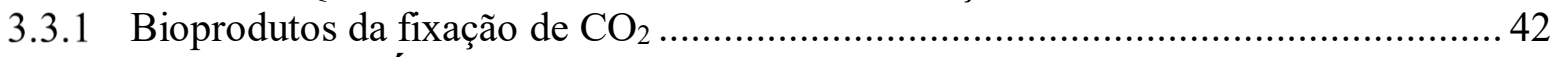

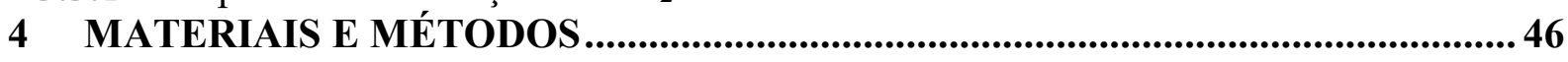

4.1 AMOSTRAS PARA O ISOLAMENTO BACTERIANO.............................................4 47

4.2 ENRIQUECIMENTO, ISOLAMENTO, SELEÇÃO E CULTIVO DE BACTÉRIAS

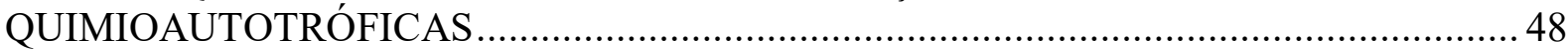

4.2.1 Etapa 1: Enriquecimento e isolamento de bactérias aclimatadas a altas concentrações

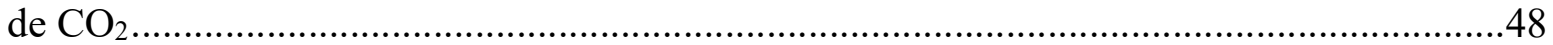

4.2.2 Etapa 2: Seleção e cultivo de bactérias quimioautotróficas .....................................52

4.2.3 Etapa 3: Avaliação de parâmetros cinéticos de crescimento e seleção de cepa para

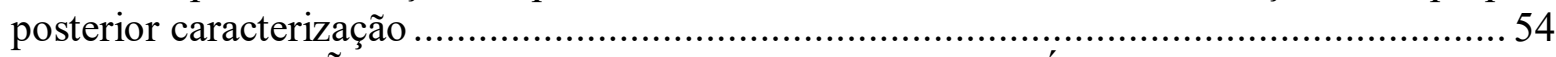

4.3 IDENTIFICAÇÃO DA CEPA SELECIONADA ATRAVÉS DE SEQUENCIAMENTO

DE 16S rDNA...............................................................................................

4.4 CARACTERIZAÇÃO DA CEPA QUIMIOAUTOTRÓFICA SELECIONADA ...........56

4.4.1 Crescimento bacteriano em diferentes concentrações de $\mathrm{CO}_{2}$ e temperatura fixa ....56

4.4.2 Crescimento bacteriano em diferentes temperaturas e concentração de $\mathrm{CO}_{2}$ fixa ....57

4.4.3 Curvas de crescimento em biomassa e medida de massa seca.................................57

4.4.4 Parâmetros cinéticos de crescimento ……………...............................................58

4.4.5 Fixação de $\mathrm{CO}_{2}$ e produtividade em biomassa ................................................59

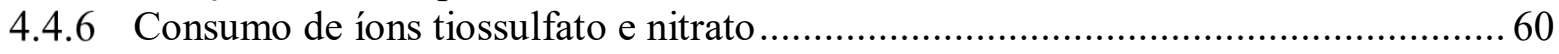

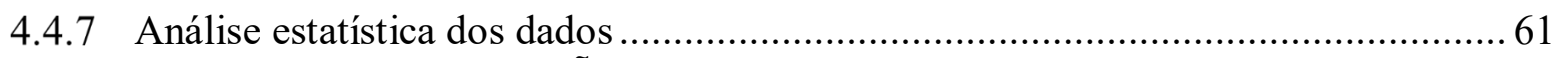

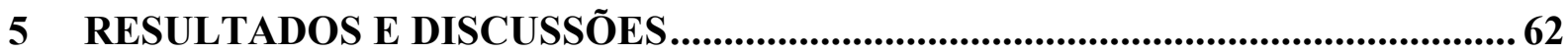

5.1 ENRIQUECIMENTO E ISOLAMENTO DE BACTÉRIAS ACLIMATADAS A CO 2.62

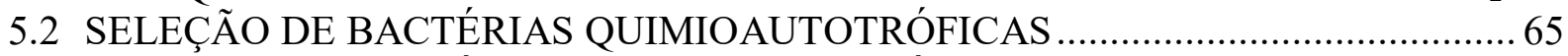

5.3 CULTIVO DE BACTÉRIAS QUIMIOAUTOTRÓFICAS EM BATELADA.................66

5.4 IDENTIFICAÇÃO DA CEPA SELECIONADA VIA SEQUENCIAMENTO DE $16 \mathrm{~s}$ rDNA.

5.5 CARACTERIZAÇÃO DA CEPA QUIMIOAUTOTRÓFICA SELECIONADA ……....73

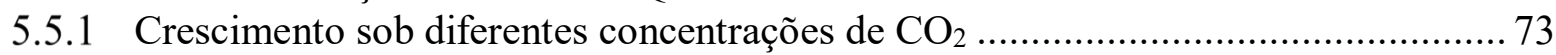

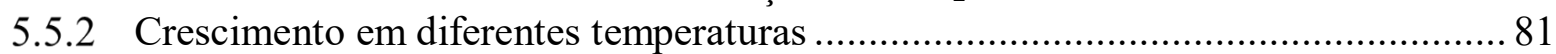

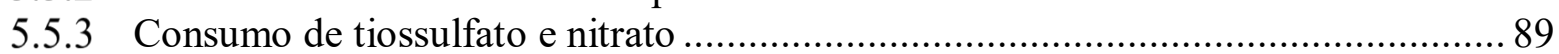

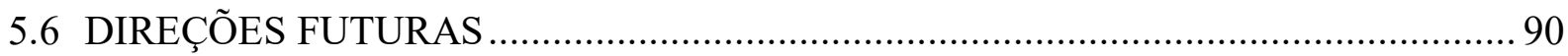

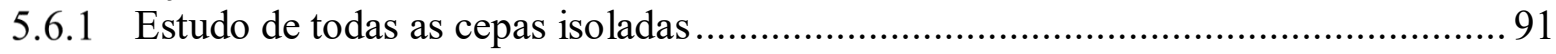

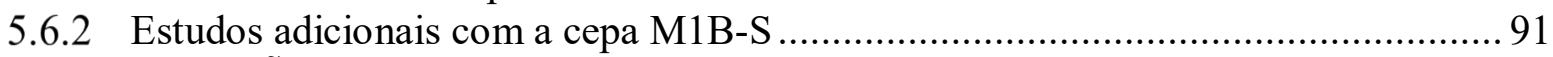

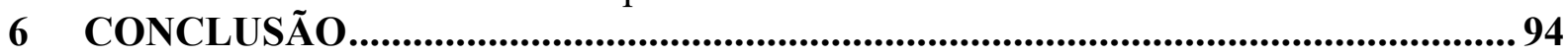




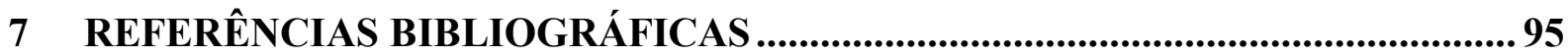

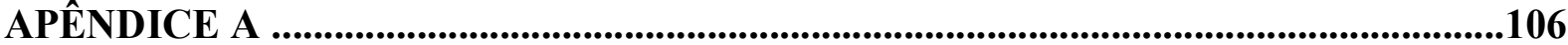

APÊNDICE B ......................................................................................................................... 107

APÊNDICE C...............................................................................................................................115

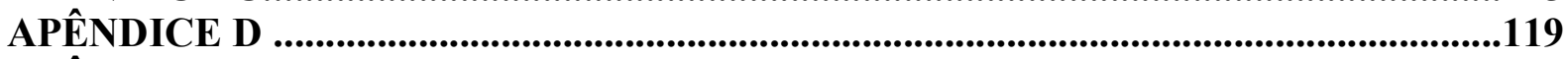

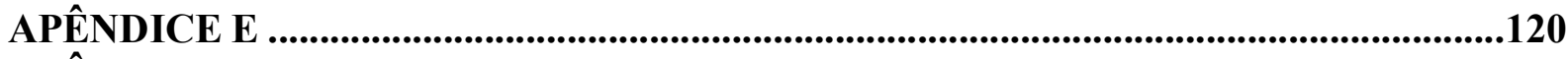

APÊNDICE F........................................................................................................................121 


\section{INTRODUÇÃO}

Os crescentes impactos ambientais decorrentes do aquecimento global têm levado governos e cientistas a desenvolver políticas internacionais e tecnologias capazes de reduzir a emissão de $\mathrm{CO}_{2}$. $\mathrm{O} \mathrm{CO}_{2}$ é reconhecido como o principal gás estufa (GEE) responsável pelo aquecimento do planeta e seus níveis na atmosfera vem crescendo anualmente (RITCHIE; ROSER, 2019; PIK, 2020). Desde o final do período pré-industrial até o ano de 2020, a concentração atmosférica de $\mathrm{CO}_{2}$ so freu um aumento superior a $47 \%$, atingindo a marca de 414 ppm (NOAA/ESRL, 2021). Projeções climáticas preveem, ainda, que caso os atuais padrões mundiais de emissões de GEEs sejam mantidos, a atmosfera terrestre poderá conter acima de $650 \mathrm{ppm}$ de $\mathrm{CO}_{2}$ ao final do século XXI. Em consequência disto, a temperatura do globo aumentará até $3,85^{\circ} \mathrm{C}$ em relação a 1850 , um aquecimento que levará a desastres ambientais e à extinção de muitas espécies (COLLINS et al., 2013; STEWART, HESSAMI, 2005).

Os atuais níveis atmosféricos de $\mathrm{CO}_{2}$ são resultado de diversas atividades antropogênicas, com destaque para a atividade industrial. As emissões do setor industrial respondem por $30 \%$ do total de $\mathrm{CO}_{2}$ liberado mundialmente e decorrem especialmente da produção e da queima de combustíveis fósseis para a geração de energia. Como consequência destas práticas, gases de combustão com teores volumétricos de $\mathrm{CO}_{2}$ entre $3-25 \%$ são produzidos e, em grande parte dos casos, emitidos diretamente na atmosfera, sem tratamento prévio (YEN et al.; 2015). Logo, setores industriais caracterizados pelo grande consumo energético e pela dependência de combustíveis fósseis representam importantes fontes emissoras de $\mathrm{CO}_{2}$ (LEESON et al. 2017).

Dentre os setores com maior pegada de carbono, o ramo de óleo e de gás ocupa papel central, sendo responsável por mais de $6 \%$ das emissões mundiais de $\mathrm{CO}_{2}$ (NYQUIST, RUYS, 2010). Especificamente neste setor, em adição à queima de combustíveis fósseis, a produção e

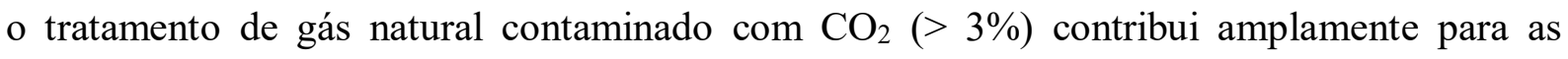
emissões de carbono (NASCIMENTO, 2012; BLANCO, 2016).

Assim, tendo em vista os acordos internacionais para a redução nas emissões de $\mathrm{CO}_{2}$, diversas técnicas físico-químicas de captura de carbono vêm sendo industrialmente implementadas. Particularmente no setor de óleo e gás, a absorção de $\mathrm{CO}_{2}$ com aminas líquidas e a separação de $\mathrm{CO}_{2}$ com membranas têm sido amplamente utilizadas no tratamento gases de combustão e de gás natural bruto. No entanto, os altos custos operacionais e as elevadas 
demandas energéticas associadas a estas tecnologias impulsionaram o desenvolvimento de alternativas baseadas na biofixação de carbono através microrganismos (ANAND, RAGHUVANSHI, GUPTA, 2020).

Microrganismos autotróficos, como microalgas e bactérias quimioautotróficas, representam promissoras estratégias de CCU (captura e utilização de carbono), já que são capazes de consumir $\mathrm{CO}_{2}$ e convertê-lo em bioprodutos com valor agregado (biomassa, biopolímeros, biossurfactantes, dentre outros) (KUMAR et al.,2018; THAKUR et al., 2018). Atualmente, o cultivo de microalgas constitui a rota de biofixação de carbono mais estudada para o tratamento de gases de combustão e de gás natural. Apesar disso, a biomitigação de $\mathrm{CO}_{2}$ através de microalgas exibe empecilhos importantes, incluindo a inibição do crescimento microalgal sob concentrações de $\mathrm{CO}_{2}$ superiores a $5 \%$ e a necessidade de fornecimento de luz artificial/natural (WANG et al., 2008).

Neste contexto, as técnicas biológicas de captura de carbono a partir de bactérias quimioautotróficas, apesar de recentes, são apontadas como potenciais soluções para mitigar as emissões de $\mathrm{CO}_{2}$ de forma sustentável e eficiente (THAKUR et al., 2018).

Desta forma, o presente projeto propõe analisar a biofixação de carbono em bactérias quimioautotróficas expostas a concentrações de $\mathrm{CO}_{2}$ superiores a 5\%. Para tanto, bactérias foram isoladas a partir de sedimentos marinhos antárticos e a sua capacidade de consumir $\mathrm{CO}_{2}$ foi caracterizada visando a sua possível aplicação no tratamento de gases de exaustão e de gás natural bruto. 


\section{OBJETIVOS}

Enriquecer, isolar e selecionar, a partir de sedimentos marinhos antárticos, bactérias capazes de realizar a biofixação de $\mathrm{CO}_{2}$ em concentrações semelhantes às encontradas nos gases de exaustão industriais e no gás natural bruto $\left(\mathrm{p}_{\mathrm{CO} 2}>0,05 \mathrm{~atm}\right.$ ou $\left.\mathrm{CO}_{2}>5 \% \mathrm{v} / \mathrm{v}\right)$.

\subsection{ETAPAS}

A fim de alcançar o objetivo proposto, o trabalho foi organizado nas seguintes etapas:

a) enriquecer e isolar, a partir de sedimentos marinhos antárticos, bactérias capazes de consumir carbono inorgânico $\left(\mathrm{C}_{\mathrm{i}}\right)$ em cultivos quimioautotróficos mantidos sob elevada concentração de $\mathrm{CO}_{2}(>5 \% \mathrm{v} / \mathrm{v})$;

b) identificar/classificar as diferentes espécies de bactérias isoladas;

c) realizar culturas em batelada das diferentes bactérias quimioautotróficas isoladas e acompanhar o seu crescimento quando submetidas a atmosferas com elevadas concentrações de $\mathrm{CO}_{2}(>5 \% \mathrm{v} / \mathrm{v})$;

d) selecionar a cepa bacteriana que apresentar a maior velocidade máxima de crescimento e o maior rendimento em biomassa quando cultivada em sistema fechado e sob condições quimioautotróficas;

e) cultivar a bactéria selecionada em sistema fechado com aporte de diferentes concentrações de $\mathrm{CO}_{2}(0 \%, 5 \%, 10 \%$ e 20\%), avaliando a fixação biológica de carbono inorgânico e a produção de biomassa nestas condições;

f) investigar a influência da temperatura de cultivo no crescimento da cepa selecionada e na sua capacidade de fixar de $\mathrm{CO}_{2}$;

g) determinar as velocidades máximas de crescimento da cepa selecionada via modelos de crescimento bacteriano; 


\section{REVISÃO DA LITERATURA}

As próximas seções deste texto apresentam a literatura e os conceitos pertinentes ao projeto de pesquisa aqui proposto.

\subsection{EMISSÕES DE $\mathrm{CO}_{2}$ E O AQUECIMENTO GLOBAL}

A constante emissão antropogênica de $\mathrm{CO}_{2}$, um dos gases do efeito estufa (GEEs), representa uma das principais causas do aquecimento global e dos danos ambientais decorrentes deste (RITCHIE; ROSER, 2019). Segundo estudos publicados por Morice et al. (2012), a temperatura média do planeta, apesar de oscilar ano a ano, aumentou de maneira abrupta nas últimas décadas. Medições realizadas no ano de 2020 comprovam que, desde o fim do período pré-industrial, em 1850, a superfície terrestre apresentou um aquecimento superior a $1,27^{\circ} \mathrm{C}$ (RHODE, 2021).

Assim como a temperatura do globo, as emissões de $\mathrm{CO}_{2}$ e demais GEEs $\left(\mathrm{CH}_{4}, \mathrm{~N}_{2} \mathrm{O}\right.$ e F-gases ${ }^{1}$ ) também sofreram acréscimos consideráveis nos últimos anos, de modo que, em 2018, 51,8 $\mathrm{GtCO}_{2} \mathrm{e}$ de gases do efeito estufa foram liberados para a atmosfera (OLIVIER; PETERS, 2019). Estes dados ambientais, suportados por modelos matemáticos, fornecem fortes evidências do impacto negativo que emissões de GEEs exercem na temperatura média do planeta (HAUSFATHER et al., 2019; HAUSFATHER, 2017). O gráfico da Figura 1 ilustra o crescimento simultâneo da temperatura do globo e das emissões de $\mathrm{CO}_{2}, \mathrm{CH}_{4}, \mathrm{~N}_{2} \mathrm{O}$ e F-gases.

Embora gases estufa como o $\mathrm{CH}_{4}$ e o $\mathrm{N}_{2} \mathrm{O}$ sejam caracterizados por elevados potenciais de aquecimento global ou GWP, a maior ameaça ao clima e ao meio ambiente é imposta pelos altos níveis de $\mathrm{CO}_{2}$ liberados na atmosfera (RITCHIE; ROSER, 2019; PIK, 2020; NOAA/ESRL, 2021). Dados de 2017, reportados pelo Instituto Potsdam de Pesquisa sobre o Impacto Climático (PIK), mostram que as emissões mundiais de $\mathrm{CO}_{2}$ superaram o valor de 35,5 Gt $\mathrm{CO}_{2} \mathrm{e}$, correspondendo a $75 \%$ do total de GEEs liberados para o ambiente. Já as emissões

\footnotetext{
${ }^{1}$ Conjunto de gases fluorados e sintéticos causadores do efeito estufa e comumente empregados em sistemas de refrigeração. Engloba os gases classificados como hidrofluorcarbonos (HFCs), perfluorcarbonos (PFCs) e hexafluoretos de enxofre $\left(\mathrm{SF}_{6}\right)$ (HEBEDA, 2017)
} 


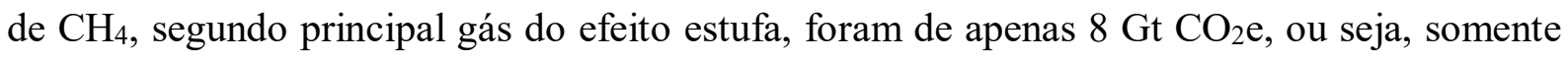
um quarto do $\mathrm{CO}_{2}$ emitido no ano de 2017(GÜTSCHOW et al., 2019). Adicionalmente, cientistas apontam que os níveis de $\mathrm{CO}_{2}$ na atmosfera aumentaram aproximadamente $50 \% \mathrm{em}$ relação ao ano de 1850 e, em 2020, atingiram 414 ppm, o maior valor da história (NOAA/ESRL, 2021).

As estatísticas descritas acima evidenciam que, apesar de acordos internacionais visarem a redução nas emissões de GEEs, grandes volumes de $\mathrm{CO}_{2}$ ainda são liberados para a atmosfera. Estas quantidades expressivas são decorrentes de diferentes atividades humanas e variam entre os países. A seguir, o cenário mundial de emissões de GEEs e as fontes emissoras de $\mathrm{CO}_{2}$ importantes para este projeto serão apresentados.

Figura 1- Séries temporais da variação na temperatura média do planeta (vermelho) e da emissão total de GEEs (preto) entre os anos de 1850 e 2018. Emissões baseadas em atividades produtivas, excluindo o uso da terra, a mudança do uso da terra e florestas (UTMUTF).

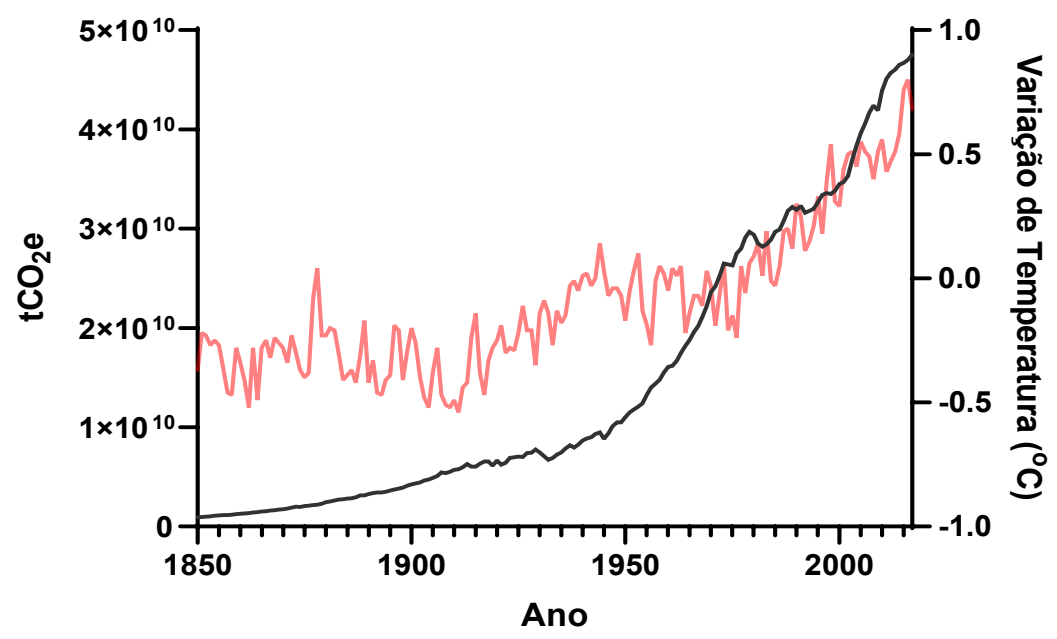

Fonte: Adaptado de Ritchie, Roser (2020)

\subsubsection{Principais fontes de emissão de $\mathrm{CO}_{2}$ e o cenário mundial}

O perfil mundial de emissões de GEEs mostra que o setor de energia, compreendendo atividades relacionadas à produção e à queima de combustíveis fósseis, é responsável por 89\% do $\mathrm{CO}_{2}$ liberado para a atmosfera (CAIT, 2019). De acordo com Ge e Friedrich (2020), as demais emissões mundiais de $\mathrm{CO}_{2}$ são associadas ao uso da terra, mudança do uso da terra e florestas ou UTMUTF (7\%), e ao setor de processos industriais e uso de produtos (4\%). Mundialmente, as atividades industriais, incluindo a queima de combustíveis e os processos 
produtivos, respondem por $30 \%$ das emissões antropogênicas de gás carbônico. Especificamente dentro do setor industrial, as indústrias de petróleo e gás (exploração e refino), de cimento e de ferro e aço são reconhecidas como as maiores emissoras de $\mathrm{CO}_{2}$ (LEESON et al., 2017).

Ainda, segundo relatório publicado pelo PIK (2020) e conforme apresentado na Figura 2, grande parte das emissões de GEEs e $\mathrm{CO}_{2}$ são concentradas em poucos países. O relatório, que não contabiliza emissões referentes ao UTMUTF, demonstra que no ano de 2017, China e EUA foram responsáveis por mais de $30 \%$ do $\mathrm{CO}_{2}$ emitido no mundo. No mesmo ano, o Brasil liberou $510 \mathrm{MtCO}_{2}$ e de gás carbônico, tornando-se o décimo maior emissor de $\mathrm{CO}_{2}(\mathrm{PIK}, 2020$; RITCHIE, ROSER, 2020). Entretanto, quando emissões associadas a UTMUTF são contabilizadas, o Brasil assume o sétimo lugar no ranking mundial.

Figura 2 - Ranking dos 10 países com maiores emissões de $\mathrm{CO}_{2}$ em 2017. Não foram contabilizadas as emissões de UTMUTF.

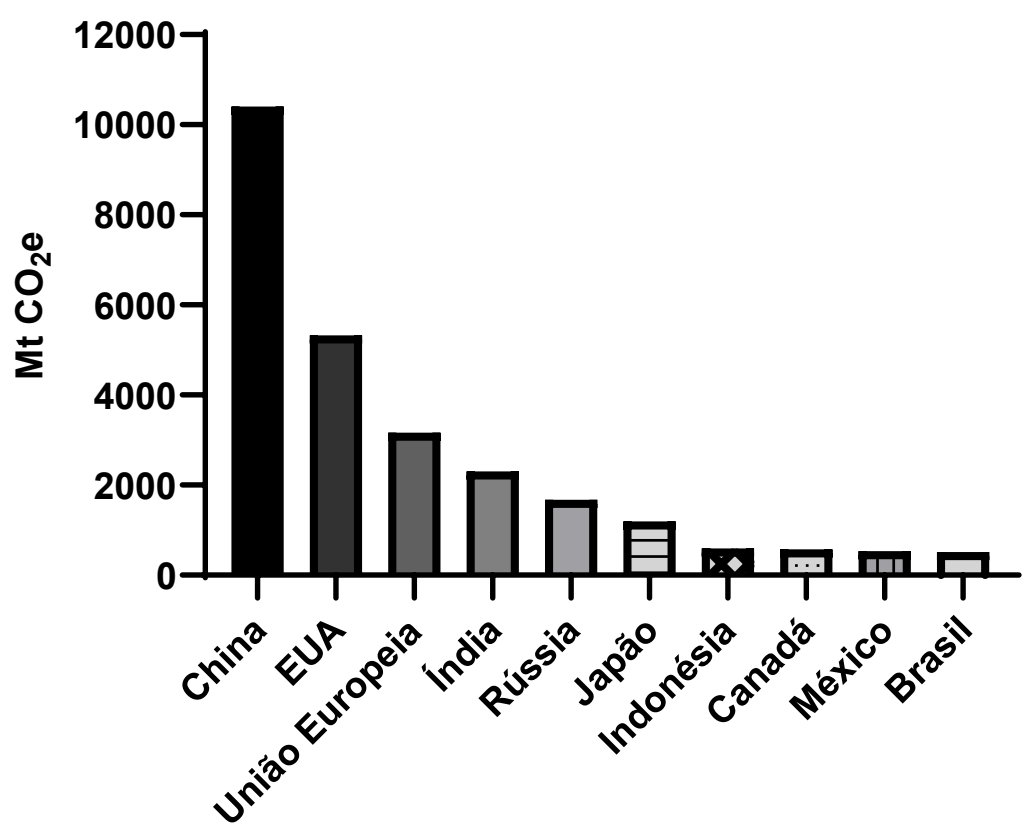

Fonte: Adaptado de PIK (2020) e Ritchie, Roser (2020).

Em 2018, de acordo com o Sistema de Estimativa de Gases do Efeito Estufa ou SEEG (2019), as emissões brasileiras de gás carbônico atingiram o patamar de 1,9 $\mathrm{GtCO}_{2} \mathrm{e}$. Destas, aproximadamente $26 \%$ são consequência da queima de combustíveis fósseis pelo setor de energia e da emissão direta de $\mathrm{CO}_{2}$ por processos industriais. Particularmente, as indústrias 
constituem as maiores fontes estacionárias de $\mathrm{CO}_{2}$ no Brasil, atrás apenas da agropecuária e da mudança de uso da terra (Figura 3).

A citada elevada liberação de carbono pelo setor industrial decorre tanto da queima de combustíveis para a geração de energia, quanto da operação de processos industriais, tais como a calcinação em cimenteiras e a produção de gás natural e derivados do petróleo (SEEG, 2018).

Figura 3 - Cenário brasileiro de emissões de GEEs por setor para o ano de 2018.

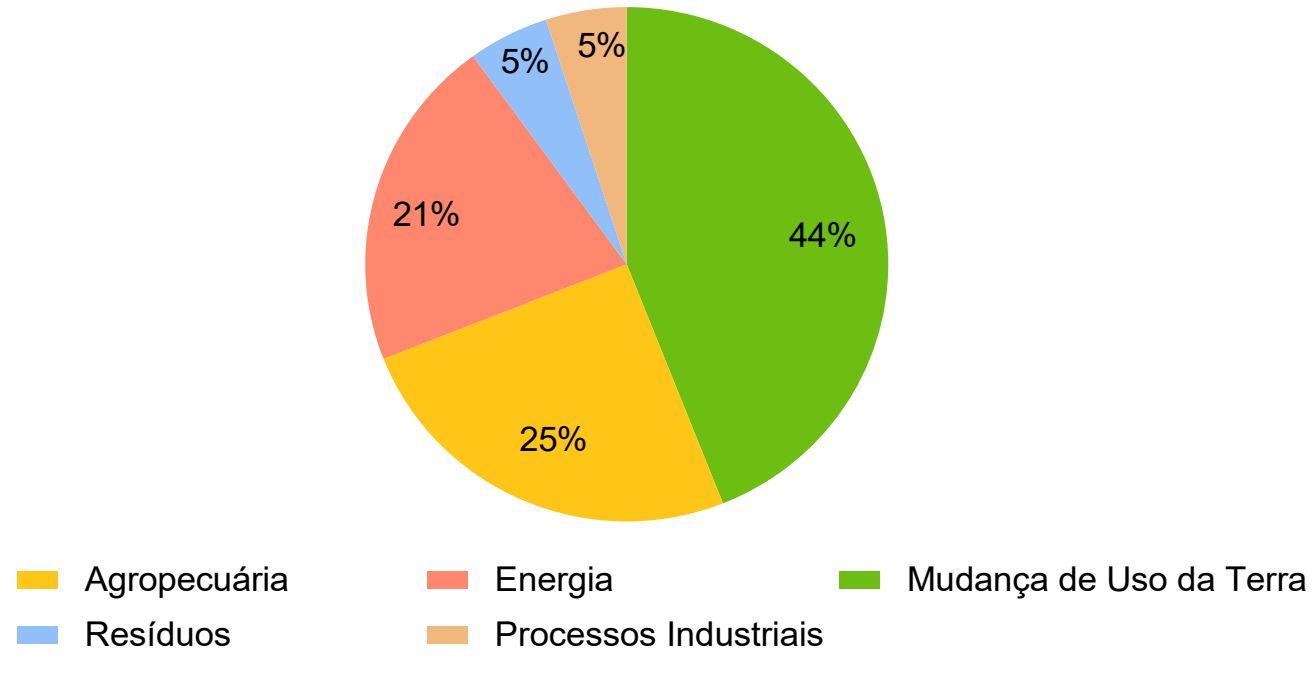

Fonte: Adaptado de SEEG (2019).

Os números acima demonstram o impacto que a produção e o uso industrial de combustíveis exercem nas emissões antropogênicas de gás carbônico. Neste contexto, as próximas seções irão abordar aspectos importantes sobre as emissões de carbono do setor industrial. Especificamente, o texto irá detalhar as fontes de emissão de $\mathrm{CO}_{2}$ existentes nas atividades petrolíferas e de produção de gás natural, ambas essenciais para a economia brasileira

\subsubsection{Uso industrial de combustíveis fósseis e a produção de gases de exaustão}

Segundo Last e Schmick (2011), a maioria das emissões industriais de $\mathrm{CO}_{2}$ resultam da queima de combustíveis fósseis para a geração de energia térmica. De modo geral, esta queima ou combustão é realizada em equipamentos como fornos, secadores e caldeiras, nos quais o combustível fóssil é oxidado na presença de um comburente, tipicamente o oxigênio contido no ar ambiente (MAIA, 2007). 
A reação de oxidação entre o combustível fóssil e o oxigênio presente no ar, além de liberar energia, produz uma mistura gasosa denominada gás de exaustão ou gás de combustão. Os principais componentes do gás de exaustão são $\mathrm{CO}_{2}, \mathrm{H}_{2} \mathrm{O}, \mathrm{N}_{2}$ e $\mathrm{O}_{2}$. No entanto, alguns processos de combustão podem acarretar a formação de contaminantes como $\mathrm{NO}_{\mathrm{x}}, \mathrm{SO}_{\mathrm{x}}, \mathrm{CO}$, $\mathrm{H}_{2} \mathrm{~S}$, mercúrio, dentre outros poluentes (IPCC, 2018).

A composição dos gases de exaustão, em especial o teor de carbono destes, é função, dentre muitos fatores, do combustível e da vazão de ar empregados na combustão. De acordo com Yen et al. (2015), as concentrações médias de $\mathrm{CO}_{2}$ em gases de exaustão industriais encontram-se na faixa de 3 a $25 \%$. Já os teores dos contaminantes $\mathrm{NO}_{\mathrm{x}}$ e $\mathrm{SO}_{\mathrm{x}}$, geralmente oscilam entre 100-300 ppm e 280-320 ppm, respectivamente (CHEAH et al., 2015). A Tabela 1 contém as faixas de concentração de $\mathrm{CO}_{2}$ e os contaminantes presentes nos gases de exaustão produzidos a partir da queima de diferentes combustíveis.

Além da composição, a temperatura do gás de exaustão é um importante parâmetro para o setor industrial. Em média, gases de exaustão gerados a partir da combustão de carvão, por exemplo, apresentam temperaturas entre $65-120^{\circ} \mathrm{C}$. Entretanto, muitas indústrias empregam processos de recuperação de energia, através dos quais os gases de combustão são resfriados a temperaturas maiores ou iguais a $30^{\circ} \mathrm{C}(\mathrm{ZHANG}, 2015)$.

Tabela 1- Teor de carbono e contaminantes presentes nos gases de exaustão provenientes da queima de diferentes combustíveis.

\begin{tabular}{ccc}
\hline Combustível & $\mathbf{C O}_{2}(\mathbf{\%}$ v/v) & Contaminantes \\
\hline Gás natural & $3-6$ & $\mathrm{SO}_{2}, \mathrm{SO}_{3}, \mathrm{NO}_{\mathrm{x}}$ \\
Carvão & $10-15$ & $\mathrm{SO}_{\mathrm{x}}, \mathrm{NO}_{\mathrm{x}}, \mathrm{Ni}, \mathrm{Hg}, \mathrm{V}, \mathrm{H}_{2} \mathrm{~S}$, etc. \\
Óleo & $3-12$ & $\mathrm{SO}_{2}\left(50-600 \mathrm{ppmv}, \mathrm{SO}_{3}, \mathrm{NO}_{\mathrm{x}}\right.$ \\
Biomassa & $3-8$ & $\mathrm{NO}_{\mathrm{x}}, \mathrm{SO}_{\mathrm{x}}$ \\
\hline
\end{tabular}

Fonte: Adaptado de Romano et al. (2013), Yen et al. (2015), Reiter e Lindorfer (2015).

Tendo em vista o alto teor de carbono presentes nos gases de exaustão $(\leq 25 \%)$, as indústrias que apresentam maiores necessidades energéticas e maior dependência de processos de combustão são as principais emissoras estáticas de $\mathrm{CO}_{2}$. Romano et al. (2013) afirmam que, além das termoelétricas, responsáveis por $80 \%$ das emissões estáticas de $\mathrm{CO}_{2}$ no mundo, as indústrias de petróleo e gás também contribuem amplamente para os elevados níveis de $\mathrm{CO}_{2}$ na atmosfera.

\subsubsection{Emissões de $\mathrm{CO}_{2}$ na indústria de petróleo e gás}


A extração, o transporte e o refino de petróleo e de gás natural são responsáveis por aproximadamente $6 \%$ do $\mathrm{CO}_{2}$ liberado no mundo (NYQUIST, RUYS, 2010). Seguindo a tendência mundial, dados do SEEG (2018) relatam que a exploração e o uso de petróleo e derivados no Brasil geraram $296 \mathrm{Mt}$ de $\mathrm{CO}_{2}$ no ano de 2018, correspondendo a $57 \%$ das emissões dos setores nacionais de energia e de processos industriais. Estas estatísticas refletem a importância que o petróleo e o gás natural exercem não só na matriz energética brasileira, mas também nas emissões de carbono do país (SEEG, 2018).

Dentro da indústria petrolífera, a extração do petróleo e do gás natural são caracterizadas pelo uso extensivo de energia, especialmente em processos de compressão, perfuração e separação. A demanda energética destas atividades é suprida através da queima de parte do óleo e do gás retirados de um reservatório, de modo que os processos de combustão resultam em $55 \%$ das emissões de $\mathrm{CO}_{2}$ associadas à produção de petróleo e gás (API, 2009). Além disso, durante a operação de uma plataforma petrolífera, elevadas quantidades de $\mathrm{CO}_{2}$ podem ser liberadas por procedimentos de flaring $^{2}$ e venting ${ }^{3}$ (BLANCO, 2016).

Em adição às atividades de exploração e extração, o transporte do óleo até as refinarias e o seu refino contribuem para os elevados volumes de $\mathrm{CO}_{2}$ liberados ao longo da produção de gás natural e de derivados do petróleo. Segundo Chan et al. (2016), as emissões de $\mathrm{CO}_{2}$ associadas ao refino do petróleo decorrem majoritariamente da queima de combustível para a geração de energia e, em menor escala, do craqueamento catalítico e da produção de $\mathrm{H}_{2}$. A Tabela 2 elenca as principais fontes de gás carbônico em uma indústria de refino de petróleo.

Tabela 2 - Principais fontes de emissões de $\mathrm{CO}_{2}$ em uma refinaria de petróleo.

\begin{tabular}{ccc}
\hline Fonte Emissora & $\begin{array}{c}\text { Fração das emissões em } \\
\text { uma refinaria (\%) }\end{array}$ & $\begin{array}{c}\text { Concentração de CO} \\
\text { no gás de exaustão (\%) }\end{array}$ \\
\hline Fornos e trocadores de calor (combustão) & $30-60$ & $8-10$ \\
Utilidades (combustão) & $20-50$ & 4 \\
Craqueamento Catalítico & $20-50$ & $10-20$ \\
Planta de Hidrogênio & $5-20$ & $20-99$ \\
\hline
\end{tabular}

Fonte: Adaptado de Chan et al. (2016) e IEA/UNIDO (2011).

\footnotetext{
${ }^{2}$ Queima controlada de gás natural ou de resíduos gasosos no incinerador ou flare, com o objetivo de controlar o processo de produção e garantir a segurança operativa (BLANCO, 2016)

${ }^{3}$ Ventilação ou liberação controlada de gases para a atmosfera, sem ocorrer a queima dos mesmos (BLANCO, 2016).
} 
Além de estar ligado ao impacto ambiental decorrente da produção de óleo e gás, o $\mathrm{CO}_{2}$ impõe dificuldades operacionais para parte dos campos de exploração de petróleo, particularmente no Brasil. Muitos poços do pré-sal brasileiro extraem hidrocarbonetos com elevado teor de gás carbônico, o qual deve ser removido para que o petróleo e o gás natural extraídos apresentem qualidade e valor comercial (NASCIMENTO, 2012).

\subsubsection{Exploração de gás natural contaminado com $\mathrm{CO}_{2}$}

O gás natural (GN) é definido como uma mistura de hidrocarbonetos que, em condições ambientes de pressão e temperatura, encontra-se no estado gasoso. O GN é composto essencialmente por metano $(\geq 70 \%$ ), etano, propano e butano (SHIMEKIT, MUKHTAR, 2012). A presença relativa destes e de outros hidrocarbonetos é bastante variável e é função do reservatório geológico do qual o GN é extraído. O local de origem do gás natural determina, também, a existência de impurezas ou contaminantes gasosos, tais como $\mathrm{CO}_{2}$ e $\mathrm{H}_{2} \mathrm{~S}$ (ANP, 2020; MAIA, 2007).

No Brasil, o gás natural produzido é predominantemente de origem offshore ${ }^{4}$ e do tipo associado, sendo caracterizado por coexistir com o petróleo no interior de reservatórios geológicos (ANP, 2020; FARAMAWY, ZAKI, SAKR, 2016). O gás encontrado em algumas regiões do pré-sal brasileiro, ainda, encontra-se contaminado com elevados teores de $\mathrm{CO}_{2}$, fato este que inviabiliza economicamente a sua produção e venda. Assim, grandes quantidades de GN nacional deixam de ser comercializadas e devem ser consumidas internamente nas plataformas de extração ou reinjetadas no subsolo, em campos de óleo esgotados ou em reservatórios ativos (EPE, 2019). Adicionalmente, parte do gás natural contaminado com $\mathrm{CO}_{2}$ é comumente descartado através das práticas de flaring e venting, ambas danosas ao meio ambiente. Desta forma, a exploração de $\mathrm{GN}$ rico em $\mathrm{CO}_{2}$ contribui para o aumento das emissões de carbono na indústria de petróleo, especialmente no Brasil (NASCIMENTO, 2012; BLANCO, 2016).

Conforme normas da Agência Nacional do Petróleo (ANP), o gás natural produzido no Brasil deve apresentar teores de $\mathrm{CO}_{2}$ inferiores a $3 \% \mathrm{v} / \mathrm{v}$ para poder ser comercializado (EPE,

\footnotetext{
${ }^{4}$ Petróleo e gás natural presentes em reservatórios afastados da costa, no mar (MORAIS, J.M. de, 2013).
} 
2019). Todavia, as concentrações de $\mathrm{CO}_{2}$ nos campos do pré-sal brasileiro são consideravelmente superiores ao limite comercial imposto pela ANP. Grande parte dos reservatórios de óleo e gás explorados na costa brasileira contêm de 10 a $45 \%$ (v/v) de $\mathrm{CO}_{2}$ e, consequentemente, as plataformas de exploração são equipadas com unidades de remoção de gás carbônico. Atualmente, o tratamento e a descontaminação offshore do GN brasileiro é realizado através de membranas seletivas, geralmente compostas por materiais poliméricos (EPE, 2019).

As membranas são a atual tecnologia de escolha no pré-sal, pois além de possibilitarem a produção de permeados com purezas de até $95 \%$ de $\mathrm{CO}_{2}$, ocupam um espaço físico reduzido e podem ser instaladas em plataformas offshore sem comprometer a sua estabilidade estrutural (IBP/GEE, 2017; EPE,2019). No entanto, a separação do $\mathrm{CO}_{2}$ por membranas possui sérios problemas relacionados à eficiência, seletividade e aos custos de operação. $O$ uso economicamente viável desta tecnologia restringe-se à purificação de vazões moderadas de gás natural e ao processamento de gases com altas pressões parciais de $\mathrm{CO}_{2}$ (SHIMEKIT, MUKHTAR, 2012). Ademais, o permeado rico em $\mathrm{CO}_{2}$ não pode ser liberado na atmosfera e precisa ser destinado corretamente. Nas plataformas petrolíferas, o $\mathrm{CO}_{2}$ removido por meio de membranas é comumente injetado nos reservatórios sendo explorados, em uma prática conhecida como Enhanced Oil Recovery (EOR). Entretanto, a constante injeção de $\mathrm{CO}_{2} \mathrm{em}$ poços ativos de óleo e gás aumenta o nível de contaminação dos mesmos e inviabiliza a sua exploração a longo prazo (IBP/GEE, 2017; EPE, 2019).

Em suma, a atividade petrolífera, incluindo a produção de gás natural, constitui uma importante fonte de emissões de $\mathrm{CO}_{2}$, especialmente no Brasil. Por conseguinte, a adoção de tecnologias e práticas que reduzam os níveis de carbono liberados pelo setor petrolífero tornase fundamental para que este cumpra seus compromissos ambientais. Dentre estas práticas, as de maior potencial e viabilidade envolvem a captura de $\mathrm{CO}_{2}$ e a seu posterior uso ou conversão em compostos químicos com valor agregado.

\subsection{PROCESSOS DE SEPARAÇÃO E CAPTURA DE $\mathrm{CO}_{2}$}

Frente aos possíveis danos ambientais decorrentes das emissões de GEEs, diversas políticas climáticas e acordos internacionais foram estabelecidos nos últimos anos, a citar o 
Protocolo de Kyoto (1997) e o Acordo de Paris (2016). Dentre as muitas metas contempladas por estes acordos, a de maior destaque é a redução dos níveis de $\mathrm{CO}_{2}$ emitidos para a atmosfera (NASCIMENTO, 2012).

A fim de acatar com o principal objetivo dos tratados citados acima, países e indústrias podem adotar três principais estratégias: 1) substituir os combustíveis fósseis por fontes de energia renováveis, 2) utilizar a energia de maneira mais eficiente e 3) implementar tecnologias para a captura e sequestro de $\mathrm{CO}_{2}(\mathrm{CCS})$ ou captura e utilização de $\mathrm{CO}_{2}(\mathrm{CCU})$ (YANG et al., 2008). As estratégias envolvendo o uso exclusivo de fontes de energia renováveis e de sistemas de energia eficientes constituem soluções a longo prazo, já que ainda dependem de elevados investimentos econômicos e de um amplo progresso técnico-científico. Ademais, tendo em vista que $85 \%$ da demanda energética mundial ainda é suprida pela queima de combustíveis fósseis, a implementação de tecnologias para a captura de carbono (CCS ou CCU) constitui uma resposta imediata para a problemática das emissões de $\mathrm{CO}_{2}$ (KENARSARI et al., 2013).

As tecnologias de captura carbono são definidas como processos voltados para a separação do gás carbônico emitido por fontes pontuais, como indústrias e plataformas petrolíferas. $\mathrm{O}$ foco central de tais tecnologias é isolar ou separar o $\mathrm{CO}_{2}$ de outros compostos gasosos e evitar a sua liberação direta para a atmosfera. Desta forma, em adição ao uso de processos de separação, a não emissão de carbono para o ambiente requer, ainda, a correta destinação do $\mathrm{CO}_{2}$ separado. Para tanto, associados à captura de carbono, diversos métodos de sequestro ou uso de $\mathrm{CO}_{2}$ também devem ser aplicados nas indústrias (YANG et al., 2008).

De acordo com Cuéllar-Franca e Azapagic (2015), um típico processo de captura e sequestro de carbono ou CCS consiste em inicialmente separar o $\mathrm{CO}_{2}$ de uma corrente gasosa para, posteriormente, injetá-lo e armazená-lo em estruturas geológicas subterrâneas, tais como aquíferos salinos, reservatórios de combustíveis fósseis e depósitos oceânicos. Haszeldine (2009) afirma que, apesar de empregado por algumas indústrias termoelétricas e petrolíferas, o sequestro geológico de carbono apresenta sérias desvantagens, principalmente em relação à possibilidade de vazamento, às capacidades limitadas de armazenamento e aos riscos ambientais oferecidos. Além disso, os custos econômicos e energéticos desta estratégia são elevados e frequentemente inviabilizam a sua aplicação comercial.

Diferentemente das práticas de CCS, as tecnologias de captura e utilização de carbono ou CCU exibem menores custos e riscos de implementação, além de fornecerem um destino permanente para o $\mathrm{CO}_{2}$ capturado a partir do gás natural e dos gases de combustão. Através da 
$\mathrm{CCU}$, o $\mathrm{CO}_{2}$ é primeiramente removido de efluentes gasosos industriais e, subsequentemente, é utilizado como matéria-prima para a síntese química ou biológica de produtos com valor comercial, tais como combustíveis, reagentes orgânicos, polímeros e fertilizantes (CUÉLLARFRANCA, AZAPAGIC, 2015; STYRING et al., 2011).

A aplicação de estratégias de CCS ou de CCU para reduzir a pegada de carbono das indústrias necessita, impreterivelmente, de etapas eficientes e viáveis de captura/separação do $\mathrm{CO}_{2}$. Diversas tecnologias de separação do $\mathrm{CO}_{2}$ de correntes gasosas são reportadas na literatura e podem ser utilizadas tanto para o tratamento de gases de exaustão, quanto para a purificação de gás natural (NASCIMENTO, 2012; THAKUR et al., 2018).

No caso específico da captura do carbono proveniente da queima de combustíveis fósseis, um dos focos deste trabalho, três possíveis abordagens podem ser empregadas para promover a recuperação/separação do $\mathrm{CO}_{2}$ contido nos gases de exaustão: a oxi-combustão, a pré-combustão e a pós-combustão (STYRING et al., 2011).

Na oxi-combustão, a queima de combustíveis é realizada na presença de oxigênio puro, de modo a gerar gases de exaustão compostos essencialmente por $\mathrm{CO}_{2}$ e $\mathrm{H}_{2} \mathrm{O}$ e separáveis por condensação (Figura 4). Já na pré-combustão (Figura 5), os combustíveis fósseis são inicialmente convertidos a uma mistura gasosa de $\mathrm{CO}_{2}$ e $\mathrm{H}_{2}$ (gás de síntese) através de métodos como o ciclo combinado com gaseificação integrada (IGCC, do inglês "Integrated Gasification Combined Cycle") e a reforma a vapor de metano. $\mathrm{O} \mathrm{CO}_{2}$ contido na mistura é separado do $\mathrm{H}_{2}$ e este é posteriormente comburido (MAIA, 2007; STYRING et al., 2011; CUÉLLARFRANCA, AZAPAGIC, 2015).

Figura 4 - Fluxograma de um processo de oxi-combustão.

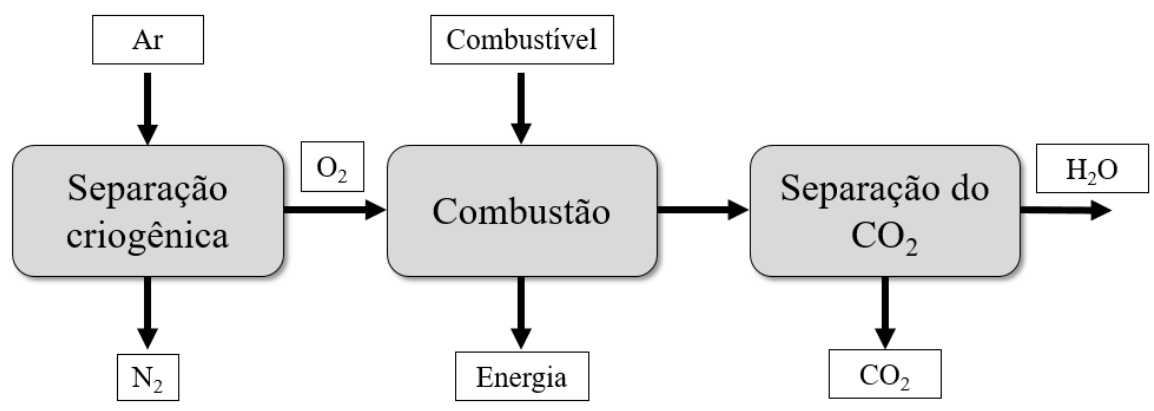


Figura 5 - Fluxograma de um processo de pré-combustão.

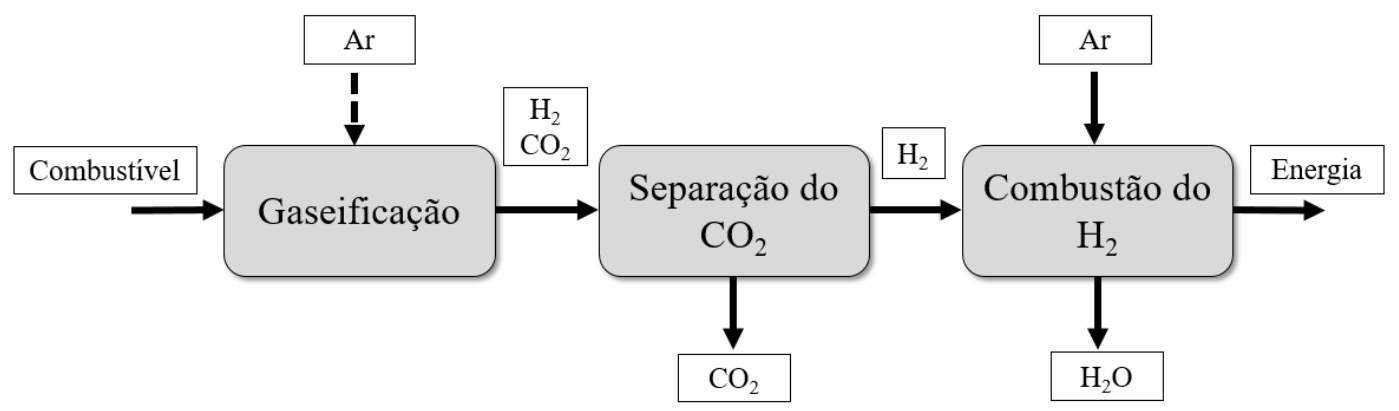

Entretanto, devido aos elevados investimentos capitais e à baixa flexibilidade operacional, a captura de carbono por oxi-combustão ou por pré-combustão é aplicada apenas em algumas termoelétricas. Em oposição a este fato, as técnicas de captura pós-combustão são difundidas em diversos setores industriais, incluindo refinarias e plataformas de produção de gás natural (STYRING et al., 2011). Conforme Songolzadeh et al. (2014), o princípio da captura pós-combustão é a remoção do $\mathrm{CO}_{2}$ de gases de exaustão após o processo de combustão. Para isso, vários métodos físico-químicos e biológicos podem ser utilizados. Ademais, os métodos de separação de carbono pós-combustão também são eficientes para a purificação de gás natural contaminado com $\mathrm{CO}_{2}$ (SHIMEKIT, MUKHTAR, 2012).

Por conseguinte, tendo em vista que o presente trabalho objetivo estudar uma alternativa biológica para mitigar as emissões de carbono associadas a gases de exaustão e à exploração de gás natural, as principais tecnologias de captura de $\mathrm{CO}_{2}$ pós-combustão serão descritas e comparadas a seguir.

\subsubsection{Processos físico-químicos de captura de $\mathrm{CO}_{2}$}

Os processos físico-químicos de captura de carbono correspondem às tecnologias mais maduras para separar o $\mathrm{CO}_{2}$ de gases de combustão e do gás natural. Dentre estes processos, os de maior destaque comercial são a absorção química e física, a adsorção, a destilação criogênica e a separação por membranas (THAKUR et al., 2018; NASCIMENTO, 2012).

a) Absorção química e física de $\mathrm{CO}_{2}$ : 
As tecnologias de captura de carbono por absorção são amplamente empregadas no setor industrial e fundamentam-se na remoção do $\mathrm{CO}_{2}$ através de sua dissolução seletiva em um solvente líquido (KOYTSOUMPA, BERGINS, KAKARAS, 2018). Um típico processo de captura de $\mathrm{CO}_{2}$ por absorção envolve, além da solubilização do $\mathrm{CO}_{2}$ em fase líquida, a regeneração do solvente utilizado. Através da regeneração, o gás carbônico absorvido é termicamente separado do solvente líquido, que pode ser reutilizado (MAIA, 2007; SONGOLZADEH et al., 2014). A Figura 6 resume o fluxograma de um processo de absorção de $\mathrm{CO}_{2}$.

Figura 6 - Fluxograma de processo de absorção de $\mathrm{CO}_{2}$.

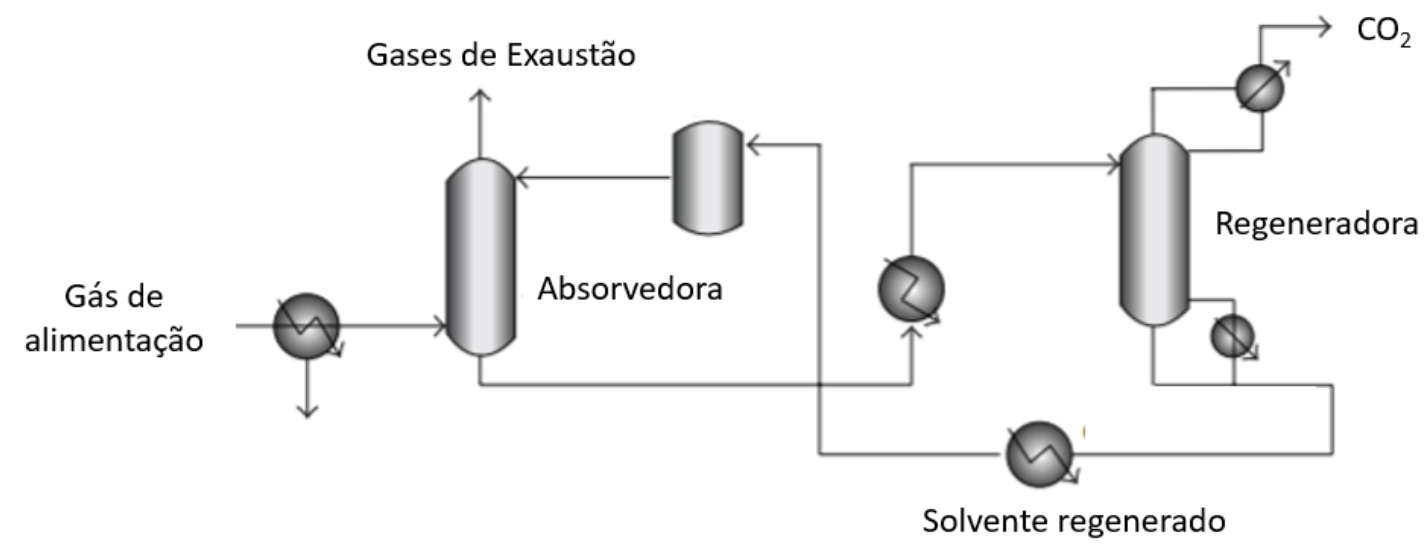

Fonte: Adaptado de Songolzadeh et al. (2014).

Diversos solventes, classificados como físicos ou químicos, estão comercialmente disponíveis para a absorção de $\mathrm{CO}_{2}$. Os solventes físicos, tais como o dimetil-éter de polietileno glicol e o metanol, são substâncias com elevadas estabilidades químicas e nas quais o $\mathrm{CO}_{2}$ apresenta grande solubilidade. Os solventes químicos, por sua vez, são compostos alcalinos capazes de reagir com o $\mathrm{CO}_{2}$ e neutralizá-lo por meio de reações ácido-base. Soluções à base de carbonato de potássio e de alcalonaminas, como a monoetanolamina (MEA) e a metildietanolamina (MDEA), são os solventes químicos mais utilizados na absorção de carbono inorgânico (KOYTSOUMPA, BERGINS, KAKARAS, 2018).

Apesar da ampla comercialização, as tecnologias de absorção de $\mathrm{CO}_{2}$ possuem sérias desvantagens, especialmente em relação à alta corrosividade e degradabilidade de alguns solventes e aos elevados custos energéticos associados à regeneração dos mesmos (MARKEWITZ et al., 2012). Ainda, a capacidade de absorção de muitos dos solventes é limitada, especialmente se o gás tratado contém $\mathrm{SO}_{x}, \mathrm{NO}_{\mathrm{x}}$ e $\mathrm{O}_{2}$ (YU, HUANG, TAN, 2012). 
b) Adsorção de $\mathrm{CO}_{2}$ :

A adsorção de $\mathrm{CO}_{2}$ em sólidos adsorventes constitui uma importante alternativa às técnicas de absorção. Na adsorção, mediante a aplicação de altas pressões, as moléculas de $\mathrm{CO}_{2}$ ligam-se quimicamente ou fisicamente à superfície de um material adsorvente. A regeneração do adsorvente e a consequente liberação do $\mathrm{CO}_{2}$ adsorvido pode ser atingida com a redução na pressão de operação ou o aumento na temperatura do processo. Adsorventes comumente usados para capturar carbono são os óxidos de cálcio e de magnésio, as zeólitas, o carvão ativado, as peneiras moleculares, o zirconato de lítio, redes metalo-orgânicas (MOFs) e os hidretos de cálcio (THAKUR et al., 2018; MAIA, 2007). Em comparação com a absorção, os sistemas de adsorção apresentam menores demandas energéticas, embora possuam reduzidas capacidades de captura na presença de umidade e de baixas pressões parciais de $\mathrm{CO}_{2}$ (YU, HUANG, TAN, 2012).

c) Separação por membranas e destilação criogênica:

Em adição à absorção e à adsorção, a separação por membranas e a destilação criogênica são tecnologias atualmente implementadas na captura de carbono. Em unidades de separação por membranas, conforme descrito nas seções anteriores, o $\mathrm{CO}_{2}$ é seletivamente transportado através da membrana, sendo obtido no permeado. Os maiores obstáculos para a ampla adoção de processos de separação por membranas são as baixas seletividades dos sistemas existentes e a necessidade de elevadas pressões de operação (WANG et al., 2011, THAKUR et al., 2018). $\mathrm{Na}$ destilação criogênica, o $\mathrm{CO}_{2}$ é separado dos gases de combustão ou do gás natural por meio de estágios sucessivos de compressão, resfriamento e expansão. Ao final da destilação, o $\mathrm{CO}_{2}$ é obtido como um condensado de elevada pureza. A principal desvantagem desta tecnologia é a grande demanda energética associada à refrigeração e à compressão dos gases tratados (SONGOLZADEH et al, 2014).

Embora sejam o estado da arte da captura de carbono, as tecnologias físico-químicas de separação de $\mathrm{CO}_{2}$ são caraterizadas por problemas operacionais. Particularmente, todos os processos físico-químicos aqui descritos necessitam de elevados investimentos econômicos e energéticos, além de apresentarem eficiências extremamente variáveis e dependentes das condições dos gases de alimentação (SONGOLZADEH et al, 2014; MAIA, 2007). Ademais, estas técnicas somente realizam a remoção ou captura do carbono, e etapas posteriores de sequestro geológico ou de uso industrial são necessárias para evitar a liberação do $\mathrm{CO}_{2}$ na atmosfera. 


\subsubsection{Processos biológicos de captura de $\mathrm{CO}_{2}$}

Recentemente, a fixação biológica de carbono ganhou destaque como uma técnica sustentável para promover não somente a captura, mas também o uso do $\mathrm{CO}_{2}$ contido em gases de exaustão e no gás natural. Diferentes estratégias biológicas de CCU vêm sendo desenvolvidas em escala laboratorial e piloto, e as mais importantes serão aqui contempladas.

\subsubsection{Captura/ fixação biológica e uso de $\mathrm{CO}_{2}$ por microrganismos autotróficos}

Além de organismos fotossintetizantes como plantas e algas, microrganismos autotróficos (cianobactérias, microalgas, arqueobactérias e bactérias quimioautotróficas) também são estudados como potenciais agentes para a captura ou fixação biológica de $\mathrm{CO}_{2}$ (KUMAR et al., 2017; SALEHIZADEH, YAN, FARNOOD, 2020).

Os microrganismos, assim como os demais seres vivos, necessitam majoritariamente de carbono e energia para o crescimento e manutenção celular (HU et al., 2010; CHEAH et al., 2016). De modo específico, os organismos classificados como autotróficos são capazes de assimilar e utilizar o $\mathrm{CO}_{2}$ (carbono inorgânico) como a única fonte do carbono necessário para a biossíntese celular. A assimilação autotrófica de $\mathrm{CO}_{2}$ e a sua posterior conversão em estruturas celulares complexas demanda energia e elétrons, os quais podem ser obtidos através da luz ou da oxidação de compostos químicos (HÜGLER, SIEVERT, 2011; HU et al., 2010).

\section{a) Microalgas:}

$\mathrm{O}$ cultivo de microalgas representa a estratégia de biofixação de $\mathrm{CO}_{2}$ de maior relevância industrial na atualidade (JAJESNIAK, ALI, WONG, 2014). As microalgas são organismos fotossintetizantes que apresentam a capacidade de fixar carbono inorgânico dissolvido (DIC) e convertê-lo em biomassa e biomoléculas de valor agregado (ZHOU et al., 2017). A energia necessária para a captura de DIC pode ser fornecida pela luz solar natural ou por luz artificial. Em comparação com plantas terrestres, as microalgas possuem maiores taxas 
de crescimento e de fixação de $\mathrm{CO}_{2}$, com eficiências de fotossíntese até 50 vezes superiores (JAJESNIAK, ALI, WONG, 2014).

Além do carbono inorgânico e da luz, o crescimento das microalgas é condicionado ao consumo de nutrientes como nitrogênio $(\mathrm{N})$, fósforo $(\mathrm{P})$, minerais e vitaminas. Uma das principais características das microalgas é a sua habilidade de fixar $\mathrm{CO}_{2}$ tanto em baixas concentrações, como no ar atmosférico $(0,03-0,06 \% \mathrm{v} / \mathrm{v})$, quanto em concentrações relativamente maiores. No entanto, apesar de estudos reportarem espécies de microalgas adaptadas a concentrações de $\mathrm{CO}_{2}$ superiores a $20 \%(\mathrm{v} / \mathrm{v})$, grande parte destes microrganismos não tolera teores de gás carbônico acima de 2-5\% (v/v) e, consequentemente, é incapaz de eficientemente remover o carbono de gases de combustão $\left(10-20 \% \mathrm{CO}_{2} \mathrm{v} / \mathrm{v}\right)(\mathrm{ZHOU}$ et al., 2017; MISTRY et al., 2019). Adicionalmente, temperaturas diferentes de $15-26^{\circ} \mathrm{C}$ e a presença de $\mathrm{SO}_{\mathrm{x}}$ e $\mathrm{NO}_{\mathrm{x}}$ nos gases de exaustão e no gás natural, por exemplo, afetam negativamente o crescimento das principais cepas de microalgas estudadas na biofixação de $\mathrm{CO}_{2}$ (WANG et al., 2008).

De modo geral, as principais desvantagens do uso de microalgas na captura de carbono, além das já citadas limitações de concentração de $\mathrm{CO}_{2}$ e de temperatura, são a necessidade de fornecimento uniforme de luz e de agitação, o consumo elevado de nutrientes e de água, a susceptibilidade à contaminação por bactérias e fungos e a produção de $\mathrm{CO}_{2}$ em períodos de ausência de luz. Consequentemente, a demanda energética e os custos associados a cultivos de microalgas são elevados e dificultam o seu emprego no tratamento de gases de combustão e de gás natural (JAJESNIAK, ALI, WONG, 2014; CHEAH et al., 2016).

b) Bactérias fototróficas e quimioautotróficas:

Assim como as microalgas, bactérias autotróficas também são capazes de capturar carbono inorgânico e convertê-lo em moléculas orgânicas. A energia necessária para que estas bactérias assimilem $\mathrm{CO}_{2}$ pode ser fornecida através da luz, natural ou artificial, ou da oxidação de compostos químicos reduzidos (HÜGLER, SIEVERT, 2011). As bactérias capazes de fixar $\mathrm{CO}_{2}$ mediante a absorção energia luminosa, tais como as cianobactérias, as bactérias púrpuras e verdes e as heliobactérias, são classificadas como fototróficas (KIM, GADD, 2008).

Apesar de exibirem capacidades de fixação de $\mathrm{CO}_{2}$ semelhantes às microalgas, estas bactérias ainda são pouco empregadas em projetos de captura de carbono (CHEAH et al., 2016). 
López et al. (2009) e Moreno et al. (1998), por exemplo, reportam a produção de biomassa pela cianobactéria Anabaena sp. quando cultivada em um fotobiorreator alimentado com gases de combustão industriais $\left.(6 \% \mathrm{v} / \mathrm{v} \mathrm{CO})_{2}\right)$.

Ainda, em comparação a microalgas, os cultivos de bactérias fototróficas geralmente apresentam maiores velocidades de crescimento, menores demandas nutricionais e maior resistência a contaminações por outras espécies (MORENO et al., 1998). Entretanto, estes cultivos também enfrentam empecilhos quanto ao fornecimento de luz e aos elevados custos operacionais (JAJESNIAK, ALI, WONG, 2014).

Outra classe de bactérias autotróficas, as bactérias quimioautotróficas, também vem sendo avaliada em processos de biofixação de carbono inorgânico, especialmente para o tratamento de gases de combustão e de gás natural (BAE et al., 2001; KUMAR et al, 2018; CHEAH et al., 2016). Este grupo de microrganismos usualmente obtém a energia necessária para assimilar o $\mathrm{CO}_{2}$ através da oxidação de substratos inorgânicos reduzidos $\left(\mathrm{H}_{2}, \mathrm{~S}^{-2}, \mathrm{NH}_{4}^{+}\right.$, $\mathrm{S}_{2} \mathrm{O}_{3}{ }^{-2}$, dentre outros), e não necessita de energia luminosa para o seu crescimento. Adicionalmente, algumas espécies fixam $\mathrm{CO}_{2}$ simultaneamente ao consumo de compostos químicos orgânicos (mixotropia) (KIM, GADD, 2008; KELLY, 1981).

O foco em bioprocessos de captura e uso de $\mathrm{CO}_{2}$ por bactérias quimioautotróficas é recente e a literatura disponível restringe-se ao cultivo de poucas espécies (GARCIAGONZALEZ et al.,2014; BAE et al, 2001; BRIGHAM, 2019; YU, 2018). Dentre estas espécies, as bactérias oxidadoras de $\mathrm{H}_{2}$ (Knallgas), como a Cupriavidus necator (Ralstonia eutropha), apresentam grande importância, já que são capazes de capturar carbono sob condições nas quais a biofixação de $\mathrm{CO}_{2}$ por microalgas é inviabilizada ( $>10 \% \mathrm{CO}_{2}$ e no escuro) (ANAND, RAGHUVANSHI, GUPTA, 2020; YU E MUNASINGHE; 2018).

Apesar disso, o crescimento de bactérias Knallgas está condicionado ao suprimento de $\mathrm{H}_{2}$ em altas concentrações, tipicamente entre os limites de explosividade deste gás (4\%-75\% v/v). Assim, a aplicação de tais procariontes como estratégia de CCU exibe elevados riscos de explosão e demanda o fornecimento de $\mathrm{H}_{2}$ (MIYAHARA et al., 2020; HU et al., 2010). Logo, os custos das culturas destes microrganismos tornam-se comparáveis aos de microalgas.

A captura de $\mathrm{CO}_{2}$ por bactérias quimioautotróficas que não empregam o $\mathrm{H}_{2}$ como fonte de energia é raramente explorada. Alguns artigos relatam o cultivo autotrófico da cepa Serratia $s p$. utilizando $\mathrm{Na}_{2} \mathrm{~S}$, um composto tóxico e prejudicial ao meio ambiente, como fonte de energia 
química (IPCS, 2020; KUMAR, GUPTA, THAKUR, 2016; BHARTI, SRIVASTAVA, THAKUR, 2014). Ainda, poucos trabalhos avaliam a remoção de carbono por bactérias quimioautotróficas cultivadas com fontes de energia de baixas toxicidade e inflamabilidade (ANAND, RAGHUVANSHI, GUPTA 2020).

Os cultivos de bactérias quimioautotróficas oferecem possíveis vantagens em relação às culturas de microrganismos fotossintetizantes. O rápido crescimento, a capacidade de adaptação a ambientes com escassez de nutrientes, além da habilidade de assimilar $\mathrm{CO}_{2} \mathrm{em}$ elevadas concentrações ( $>5 \%$ ) e na ausência de luz, podem potencializar o uso industrial de bactérias quimiotróficas para remover o $\mathrm{CO}_{2}$ de gás natural e de gases de exaustão (ANAND, RAGHUVANSHI, GUPTA 2020).

\subsection{BACTÉRIAS QUIMIOAUTOTRÓFICAS E A FIXAÇÃO BIOLÓGICA DE CO}

As bactérias quimioautotróficas são organismos autotróficos e, portanto, capazes de sobreviver em meios minerais e de obter o carbono necessário para o seu crescimento e manutenção através de fontes inorgânicas $\left(\mathrm{CO}_{2} / \mathrm{HCO}_{3}^{-}\right)$. A assimilação e a conversão do $\mathrm{CO}_{2}$ em material biológico são realizadas por uma série de reações metabólicas distintas, cuja ocorrência é condicionada à disponibilidade de energia e elétrons. Nas células bacterianas, a energia e os elétrons utilizados no metabolismo de fixação de carbono são conservados e fornecidos por moléculas de $\mathrm{ATP}^{5}$ e $\mathrm{NAD}(\mathrm{P}) \mathrm{H}^{6}$. Estas biomoléculas, por sua vez, são sintetizadas ou regeneradas através de um conjunto de reações exergônicas de oxidaçãoredução (redox) (HÜGLER, SIEVERT, 2011; GOTTSCHALK, 1979).

Desta forma, a produção de ATP e de NAD(P)H em uma célula envolve a oxidação inicial de doadores de elétrons (fonte de energia) e a redução de aceptores finais de elétrons. Nas bactérias quimioautotróficas, os doadores iniciais de elétrons usualmente são substratos inorgânicos reduzidos $\left(\mathrm{H}_{2}, \mathrm{~S}^{-2}, \mathrm{NH}_{4}{ }^{+}, \mathrm{Fe}^{+2}\right)$, enquanto compostos oxidados, como $\mathrm{O}_{2}, \mathrm{NO}_{3}{ }^{-}$, e

${ }^{5}$ ATP (adenosna-5' - trifosfato) é a principal molécula carreadora de energia biológica utilizável. Todos as reações de biossíntese endergônicas que ocorrem em seres vivos estão associadas à conversão de ATP (alta energia) em ADP (baixa energia) (GOTTSCHALK, 1979).

${ }^{6} \mathrm{NADH}$ e NADPH são as versões reduzidas das coenzimas $\mathrm{NAD}^{+}$e $\mathrm{NADP}^{+}$. As versões oxidadas e reduzidas destas coenzimas participam das reações redox que ocorrem nas células, e exercem a função de carreadores de elétrons/prótons (GOTTSCHALK, 1979; KIM, GADD, 2008). 
$\mathrm{SO}_{4}{ }^{-2}$, são utilizados como aceptores terminais de elétrons (ANAND, RAGHUVANSHI, GUPTA 2020). O tipo de substrato consumido como fonte de energia determina a qual grupo de bactérias quimioautotróficas uma determinada espécie pertence. Logo, as diferentes cepas quimioautotróficas podem ser classificadas em bactérias oxidadoras de $\mathrm{H}_{2}$, bactérias oxidadoras de enxofre (sulfobactérias incolores), bactérias oxidadoras de amônia, bactérias oxidadoras de nitrito e bactérias de ferro (ferrobactérias). Ainda, algumas espécies consomem CO (carboxidobactérias), As (III) e Mn (II) (GOTTSCHALK, 1979).

Alternativamente, espécies de bactérias quimioautotróficas classificadas como quimiolitoautotróficas facultativas podem crescer através de metabolismos mixotróficos ou heterotróficos, baseados no consumo de carbono orgânico (KIM, GADD, 2008; KELLY, 1981).

As sulfobactérias incolores, um dos grupos mais diversos de bactérias quimiossintetizantes, são capazes de oxidar uma grande variedade de compostos inorgânicos de enxofre, incluindo sulfeto $\left(\mathrm{S}^{-2}, \mathrm{HS}^{-}\right)$, sulfito $\left(\mathrm{SO}_{3}{ }^{-}\right)$, tiossulfato $\left(\mathrm{S}_{2} \mathrm{O}_{3}{ }^{-2}\right)$ e enxofre elementar $\left(\mathrm{S}^{0}\right)$. Dentre estes substratos, o $\mathrm{S}_{2} \mathrm{O}_{3}{ }^{-2}$ é um dos mais abundantes na natureza e, devido a isso, a maioria das sulfobactérias autotróficas exibem mecanismos para oxidá-lo (GHOSH, DAM, 2009).

Além de metabolizarem uma grande diversidade de substratos, as bactérias quimioautotróficas possuem diferentes morfologias, mecanismos de fixação de carbono e habitats (KELLY, 1981). Quanto à ocorrência natural, estas bactérias geralmente são encontradas em ecossistemas onde $\mathrm{CO}_{2}$ e compostos inorgânicos reduzidos estão disponíveis. Assim, grande parte das espécies quimioautotróficas conhecidas até o momento foram isoladas de ambientes marinhos ricos em nutrientes inorgânicos, tais como fontes hidrotermais submarinas, águas e sedimentos marinhos ultraprofundos (>200 m) e sedimentos marinhos antárticos. Ademais, ambientes caracterizados por condições extremas de temperatura, pressão, $\mathrm{pH}$ ou salinidade também costumam abrigar uma grande diversidade de espécies quimiotróficas (KELLY, 1981; SAINI, 2011).

Conforme descrito, as bactérias quimioautotróficas apresentam diferentes mecanismos associados à fixação do $\mathrm{CO}_{2}$ em moléculas orgânicas. A principal função destes mecanismos é converter o $\mathrm{CO}_{2}$ em moléculas precursoras ${ }^{7}$ utilizadas nas reações de crescimento e manutenção

\footnotetext{
${ }^{7}$ As células eucarióticas e procarióticas necessitam de 13 moléculas precursoras, a partir das quais todo o material celular pode ser sintetizado. Em organismos heterotróficos, estes precursores são originados a partir da
} 
celular. Atualmente, seis principais caminhos ou rotas de fixação autotrófica de carbono são conhecidas e descritas na literatura: ciclo de Calvin-Benson-Bassham (CBB), ciclo reverso do ácido tricarboxílico (rTCA), rota Wood-Ljungdahl (acetil-CoA redutiva), ciclo do 3hydroxypropionato/4-hidroxibutirato (3HP-4HB), ciclo do dicarboxilato/4-hidroxibutirato (DC-4HB) e bi-ciclo do 3-hidroxipropionato (3-HP).

a) Ciclo de Calvin-Benson-Bassham (CBB):

$\mathrm{O}$ ciclo de Calvin é a rota de fixação de $\mathrm{CO}_{2}$ mais comum em quimioautótrofos aeróbios e em seres fotossintetizantes. Através do ciclo de CBB, 7 precursores distintos, a citar o 3fosfoglicerato (3-PGA), a frutose-6-fosfato (F6P) e a glicose-6-fosfato (G6P), são obtidos ao longo de 13 reações enzimáticas (KIM, GADD, 2008). A primeira destas reações corresponde à assimilação do carbono inorgânico e é catalisada pela enzima ribulose 1,5-bifosfato carboxilase/oxigenase ( $\mathrm{RuBisCO})$. Nesta etapa de carboxilação, $\mathrm{o} \mathrm{CO}_{2}$ é adicionado à molécula ribulose 1,5-bifosfato (RuBP), produzindo duas moléculas de 3-PGA. As 12 etapas subsequentes do ciclo de Calvin são responsáveis por regenerar a RuBP e converter o 3-PGA nos demais precursores citados acima. Dentre as enzimas envolvidas no ciclo de Calvin, três podem ser consideradas únicas e características desta rota: RuBisCO, sedoheptulose bifosfatase (SBPase) e fosforribulocinase (PRK). O ciclo de Calvin encontra-se ilustrado na Figura 7.

Em suma, a rota CBB consome 18 mol de ATP e 12 mol de NAD(P)H para cada 6 mol de $\mathrm{CO}_{2}$ fixadas (KIM, GADD, 2008):

$$
6 \mathrm{CO}_{2}+18 \mathrm{ATP}+12 \mathrm{NAD}(\mathrm{P}) \mathrm{H}+12 \mathrm{H}^{+} \rightarrow \mathrm{G} 6 \mathrm{P}+18 \mathrm{ADP}+18 \mathrm{P}_{\mathrm{i}}+12 \mathrm{NAD}(\mathrm{P})^{+}
$$

a) Ciclo TCA reverso (rTCA):

Segundo Hügler e Sievert (2011) e Kim e Gadd (2008), o ciclo redutivo/reverso do ácido tricarboxílico (rTCA) envolve o conjunto de reações inversas do ciclo TCA oxidativo (ciclo de

oxidação de substratos orgânicos. Em seres autotróficos, estes precursores são gerados a partir da assimilação e redução do $\mathrm{CO}_{2}$ (carbono inorgânico) Exemplos destes precursores são o acetil-CoA, o piruvato, o succinil-CoA e a glicose-6-fosato (KIM, GADD, 2008). 
Krebs), culminando na biossíntese do precursor acetil-CoA. O mecanismo rTCA apresenta duas etapas de carboxilação, ou seja, de fixação de $\mathrm{CO}_{2}$ : a síntese de 2-oxoglutarato a partir de succinil-CoA e a conversão de 2-oxoglutarato em isocitrato. As enzimas envolvidas nestas reações são a 2-oxoglutarato sintase e a isocitrato desidrogenase, respectivamente. Em algumas bactérias, as enzimas 2-oxoglutarato carboxilase e oxalosuccinato redutase podem realizar a função da isocitrato desidrogenase (HÜGLER, SIEVERT, 2011).

Figura 7 - Etapas do ciclo de Calvin (CBB). As enzimas envolvidas são: 1) RuBisCO, 2) 3-fosfoglicerato cinase, 3) gliceraldeido-3-fosfato desidrogenase, 4) triose fosfato isomerase, 5) frutose-1,6-difosfato aldolase, 6) frutose-1,6-difosfatase, 7) glucose-6-fosfato isomerase, 8) glucose-6-fosfatase, 9) transcetolase, 10) sedoheptulose-1,7-difosfato aldolase, 11) ribose-5-fosfato isomerase 12) ribose-5fosfato-3-epimerase, 13) PRK.

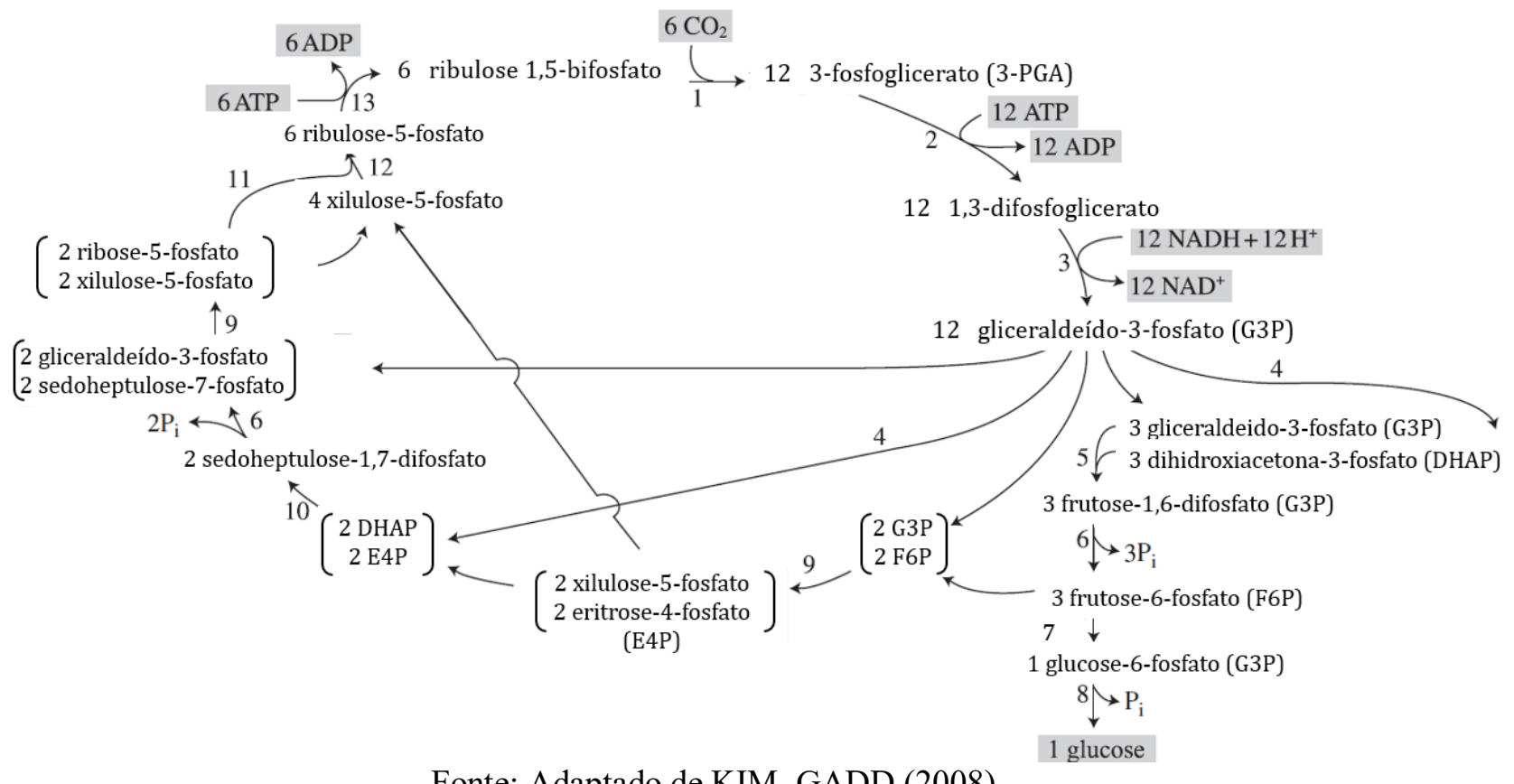

Fonte: Adaptado de KIM, GADD (2008).

Ademais, de acordo com Hügler e Sievert (2011), o ciclo TCA reverso cotém enzimas características que o distinguem da versão oxidativa sendo elas a fumarato redutase, a 2oxoglutarato sintase e a ATP citrato liase (ACL) (ou a citril-CoA sintetase/citril-CoA liase). As etapas do mecanismo rTCA são descritas na Figura 8, enquanto a equação global do ciclo é: 
Figura 8 - Etapas do ciclo redutivo do ácido tricarboxílico (rTCA).

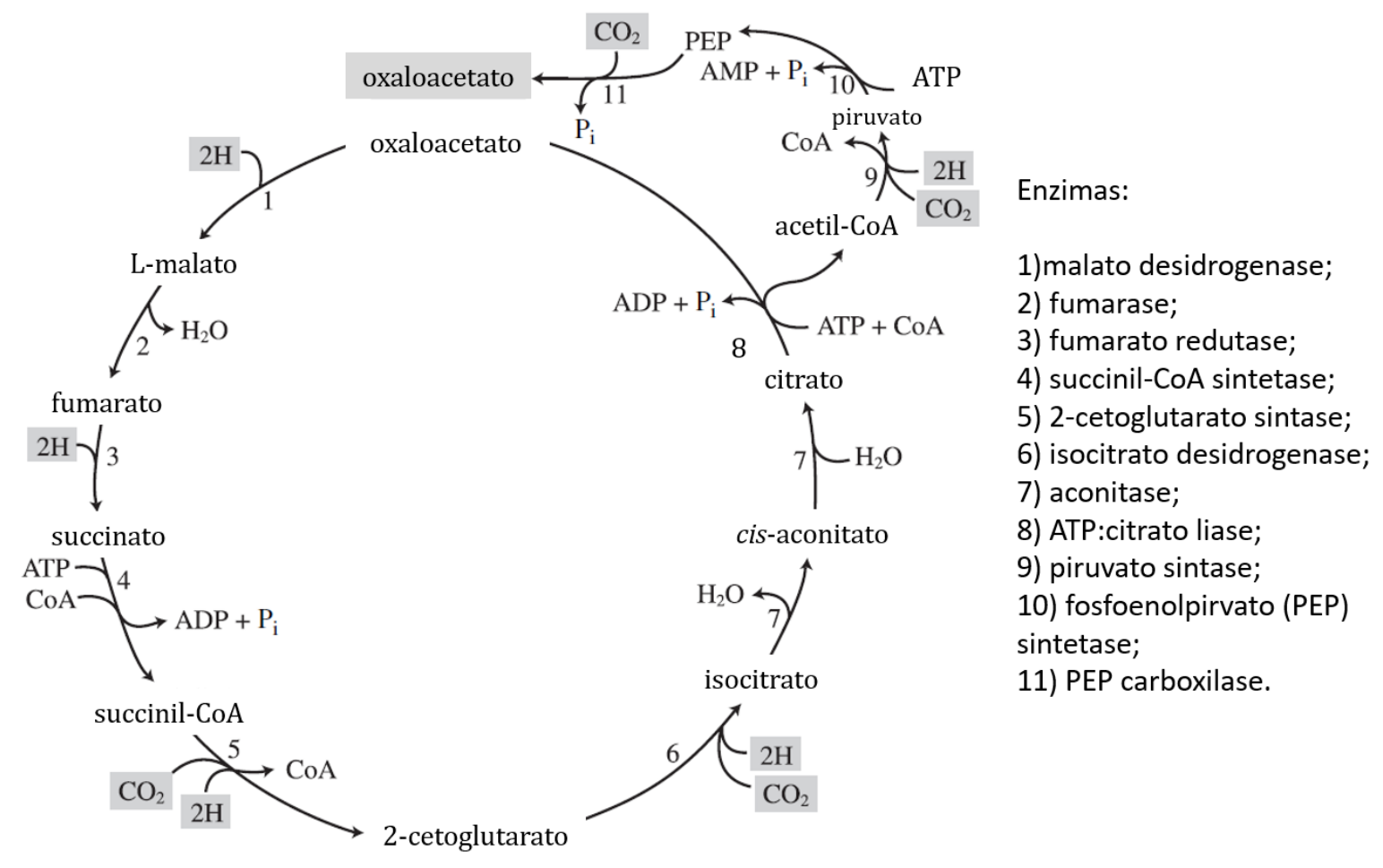

Fonte: Adaptado de KIM, GADD (2008).

Recentemente, pesquisas demonstraram a existência de variantes do ciclo rTCA. Mall et al. (2018), por exemplo, reportam que o crescimento autotrófico da bactéria Desulfurella acetivorans é possibilitado pela reversibilidade da enzima citrato sintase (CS), até então conhecida por catalisar somente a versão oxidativa do ciclo do ácido cítrico. Nesta variante do rTCA, denominada pelos autores de roTCA, a CS substitui a enzima ACL e atua na clivagem do citrato em oxaloacetato e acetil-CoA. De modo semelhante, Nunoura et al. (2018) também descreveram a atividade reversa da enzima $\mathrm{CS}$ na fixação autotrófica de $\mathrm{CO}_{2}$ pela cepa Thermosulfidibacter takaii $\mathrm{ABI} 70 \mathrm{~S} 6^{\mathrm{T}}$.

b) Rota Wood-Ljungdahl (acetil-CoA redutiva):

A rota redutiva do acetil-CoA ou rota Wood-Ljungdahl (W-L) é observada em bactérias anaeróbias estritas (KUMAR et al., 2018). Diferentemente dos mecanismos citados acima, a rota W-L não ocorre de maneira cíclica e, portanto, não regenera os aceptores primários do $\mathrm{CO}_{2}$. Não obstante, este caminho resulta na fixação de duas moléculas de $\mathrm{CO}_{2}$ para formar acetil-CoA. As enzimas fundamentais para a rota W-L são a formato desidrogenase, que catalisa 
a redução de $\mathrm{CO}_{2}$ a formato, e a enzima bifuncional $\mathrm{CO}$ desidrogenase/acetil-CoA sintase (CODH/acetil-CoA sintase), responsável pela catálise de duas etapas reacionais: a redução de $\mathrm{CO}_{2}$ a carbonil (CO) e a síntese final do precursor acetil-CoA (KIM, GADD, 2008; MINIC, THONGBAM, 2011). A equação global que representa a rota do acetil-CoA (rota W-L), ilustrado na Figura 9, corresponde à:

$2 \mathrm{CO}_{2}+\mathrm{ATP}+2 \mathrm{NADH}+2 \mathrm{H}^{+}+\mathrm{CoASH}+2 \mathrm{Fd} \cdot \mathrm{H}_{2} \rightarrow$ acetilCoA $+\mathrm{ADP}+\mathrm{P}_{\mathrm{i}}+3 \mathrm{H}_{2} \mathrm{O}+2 \mathrm{NAD}^{+}+2 \mathrm{Fd}$

Figura 9 - Etapas da rota Wood-Ljungdahl ou rota redutiva do acetil-CoA.

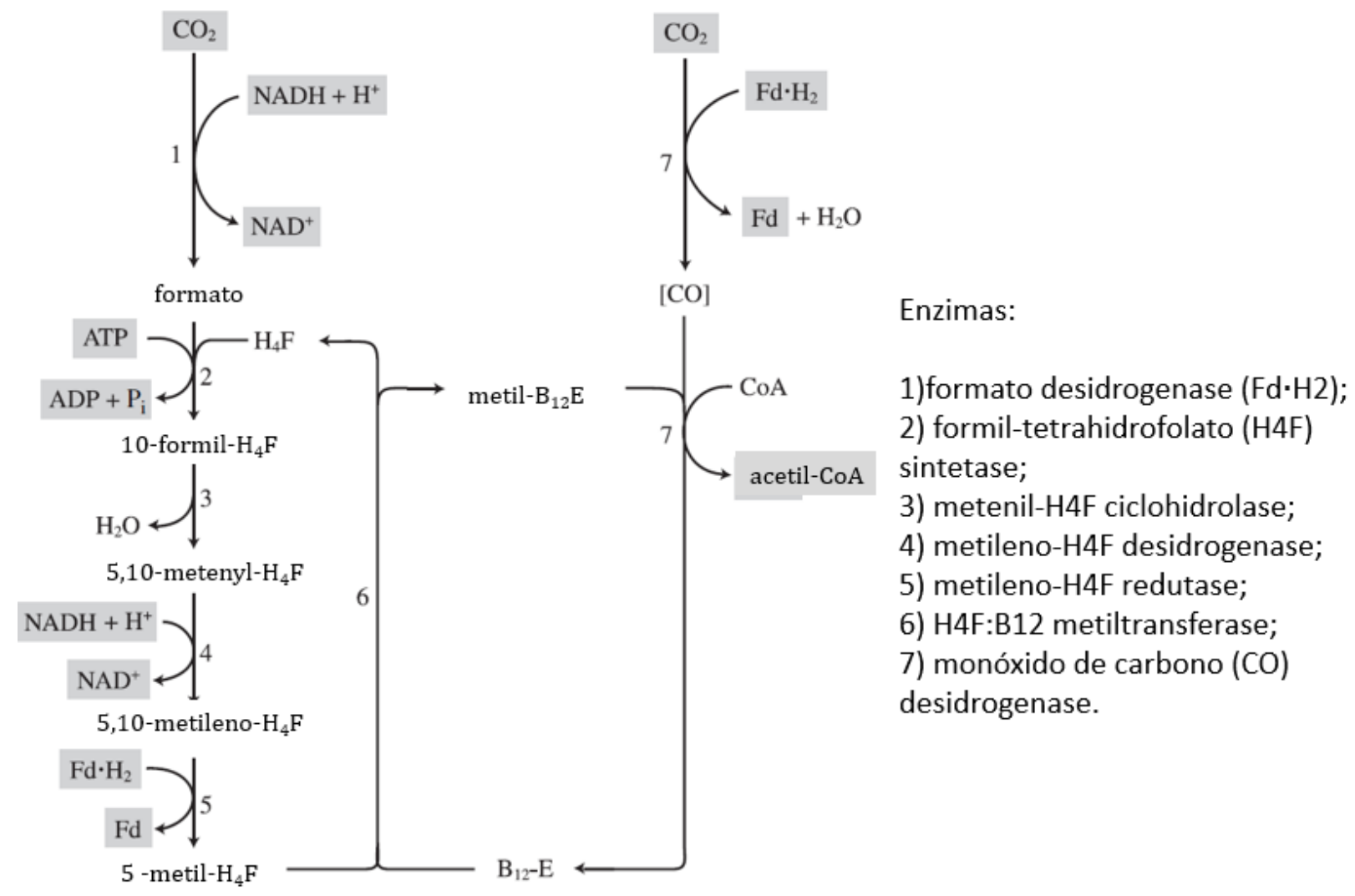

Fonte: Adaptado de KIM, GADD (2008).

c) Ciclo do 3-hydroxypropionato/4-hidroxibutirato (3HP-4HB)

O ciclo 3HP-4HB é desempenhado por algumas bactérias autotróficas termoacidofilicas e resulta na produção do precursor acetil-CoA mediante a fixação de duas moléculas de 
bicarbonato $\left(\mathrm{HCO}_{3}{ }^{-}\right)$. As principais enzimas características da rota $3 \mathrm{HP}-4 \mathrm{HB}$ são a 4hidroxibutiril-CoA desidratase, malonil-CoA redutase e as carboxilases acetil-CoA e propionilCoA (HÜGLER, SIEVERT, 2011). As reações enzimáticas envolvidas no ciclo 3HP-4HB são apresentadas na Figura 1010.

Figura 10 - Ciclo do 3-hydroxypropionato/4-hidroxibutirato (3HP-4HB).

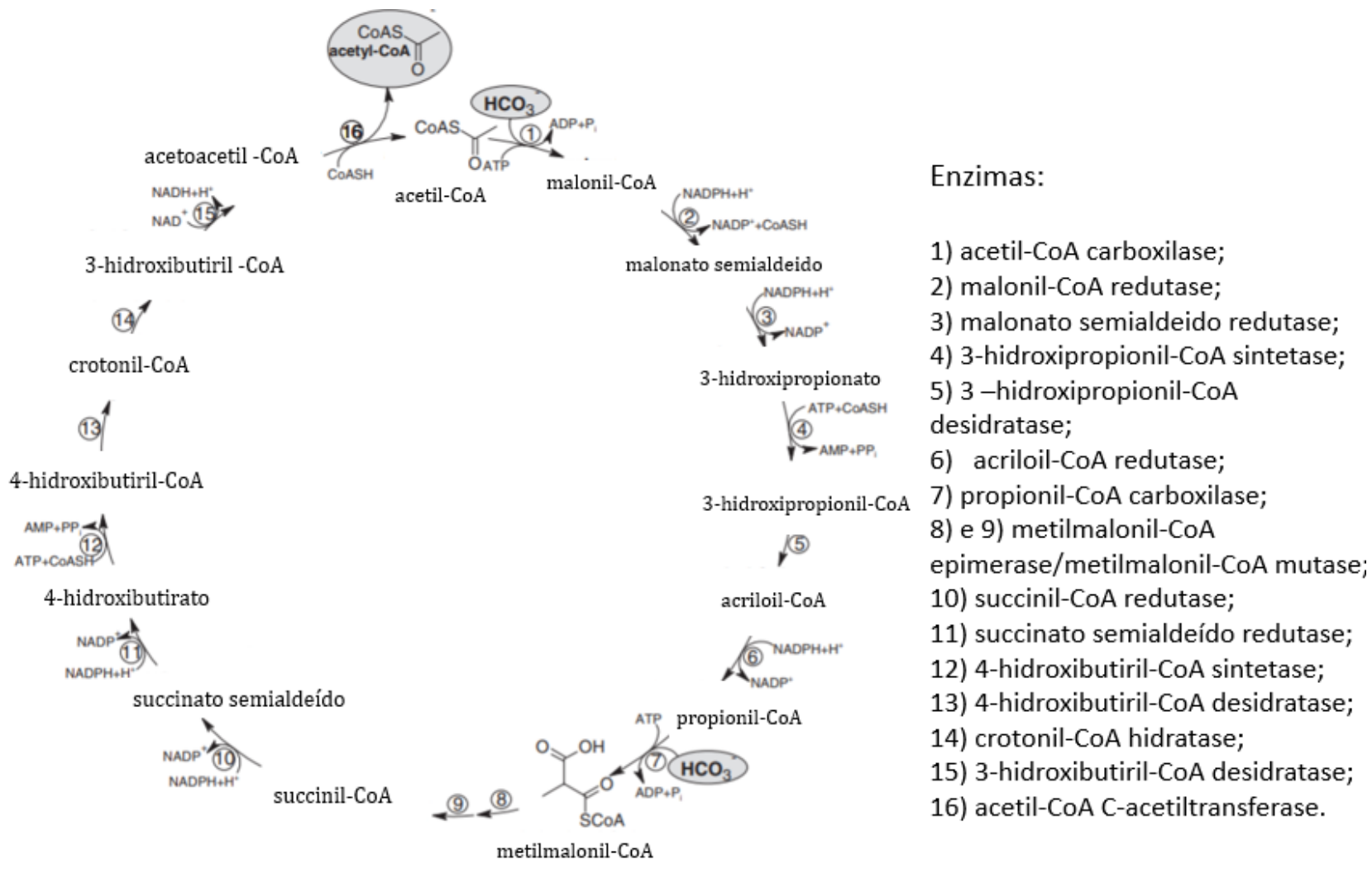

Fonte: Adaptado de BERG et al. (2007).

d) Ciclo do dicarboxilato/4-hidroxibutirato (DC-4HB)

$\mathrm{O}$ ciclo do dicarboxilato/4-hidroxibutirato, assim como a rota $3 \mathrm{HP}-\mathrm{HB}$, converte carbono inorgânico em moléculas de acetil-CoA. Todavia, o mecanismo DC-4HB assimila $\mathrm{CO}_{2}$ e $\mathrm{HCO}_{3}{ }^{-}$, além de formar succinil-CoA através de um conjunto de reações que envolve intermediários como o piruvato e o oxaloacetato e a catálise por enzimas características do ciclo rTCA (MINIC, THONGBAM, 2011). O ciclo DC-4HB não apresenta nenhuma enzima exclusiva que o caracterize. Entretanto, a presença conjunta de 4-hidroxibutiril-CoA desidratase, piruvato sintase, fosfoenolpiruvato sintetase (PEP sintetase) e PEP carboxilase pode indicar que o ciclo DC-4HB é o mecanismo de fixação de carbono ativo em uma 
determinada espécie bacteriana (HÜGLER, SIEVERT, 2011). As etapas completas deste ciclo são ilustradas na Figura 11.

Figura 11 - Ciclo do dicarboxilato/4-hidroxibutirato.

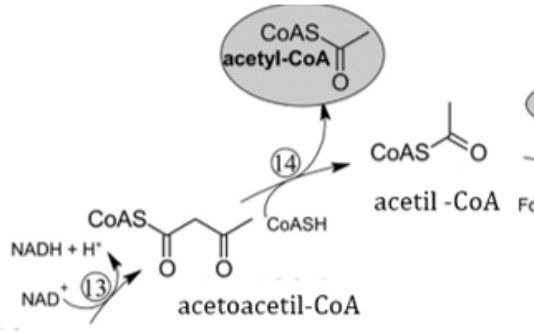

3-hidroxibutiril-CoA

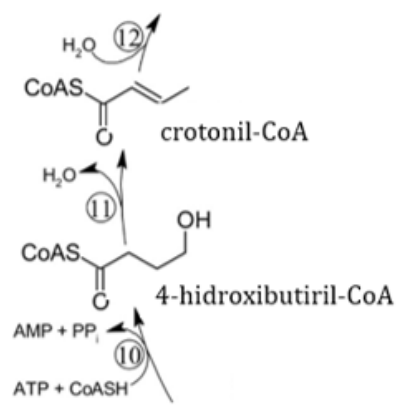

4-hidroxibutirato

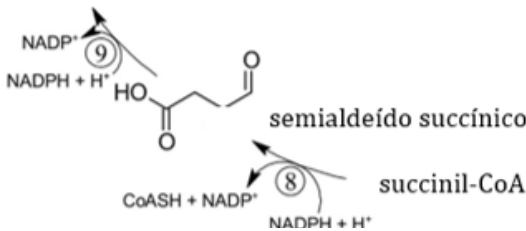

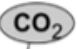

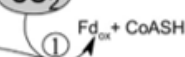

piruvato

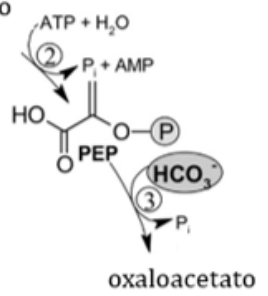

Fonte: Adaptado de HÜGLER, SIEVERT (2011).
Enzimas:

1)piruvato sintetase;

2) piruvato: água dicinase;

3) PEP carboxilase;

4) malato desidrogenase;

5) fumarato hidratase;

6) fumarato redutase;

7) succinil-CoA sintetase;

8) succinil-CoA redutase;

9) succinato semialdeído

$-\mathrm{NADH}+\mathrm{H}^{*}$ redutase;

(4) 10) 4-hidroxibutiril-CoA sintetase;

11) 4-hidroxibutiril-CoA

malato desidratase;

12) crotonil-CoA hidratase;

13) 3-hidroxibutiril-CoA

desidrogenase;

fumarato

14) acetil-CoA C-acetiltransferase.

a) Bi-ciclo do 3-hidroxipropionato (3-HP).

O bi-ciclo ou mecanismo do 3-hidroxipropionato (3-HP) é constituído por dois ciclos distintos que, juntos, fixam três moléculas de bicarbonato $\left(\mathrm{HCO}_{3}{ }^{-}\right)$e sintetizam uma molécula de piruvato, que pode ser empregado no metabolismo de carboidratos (KIM, GADD, 2008; HANSON ALBERT, TABITA, 2012). As enzimas chave do bi-ciclo 3-HP, resumido na Figura 12, são a acetil-CoA carboxilase, a propionil-CoA carboxilase, malonil-CoA redutase, propionil-CoA sintase e a malil-CoA/ $\beta$-metilmalil-CoA/citramalil-CoA (MMC) liase (HÜGLER, SIEVERT, 2011). 
Figura 12 - Bi-ciclo do 3-hidroxipropionato. As enzimas envolvidas nas duas etapas desta rota são: 1) acetil-CoA carboxilase; 2) malonil-CoA redutase; 3) propionil-CoA sintase; 4) propionil-CoA carboxilase; 5) metilmalonil-CoA epimerase; 6) metilmalonil-CoA mutase; 7) succinato desidrogenase/fumarato hidratase; 8) succinil-CoA:L-malato CoA transferase; 9) L-malil-CoA liase; 10) eritro-3-metilmalil-CoA liase; 11) 3-metilmalil-CoA desidratase; 12) mesaconil-CoA hidratase; 13) succinil-CoA:L-citramalato-CoA transferase; 14) citramalil-CoA liase.

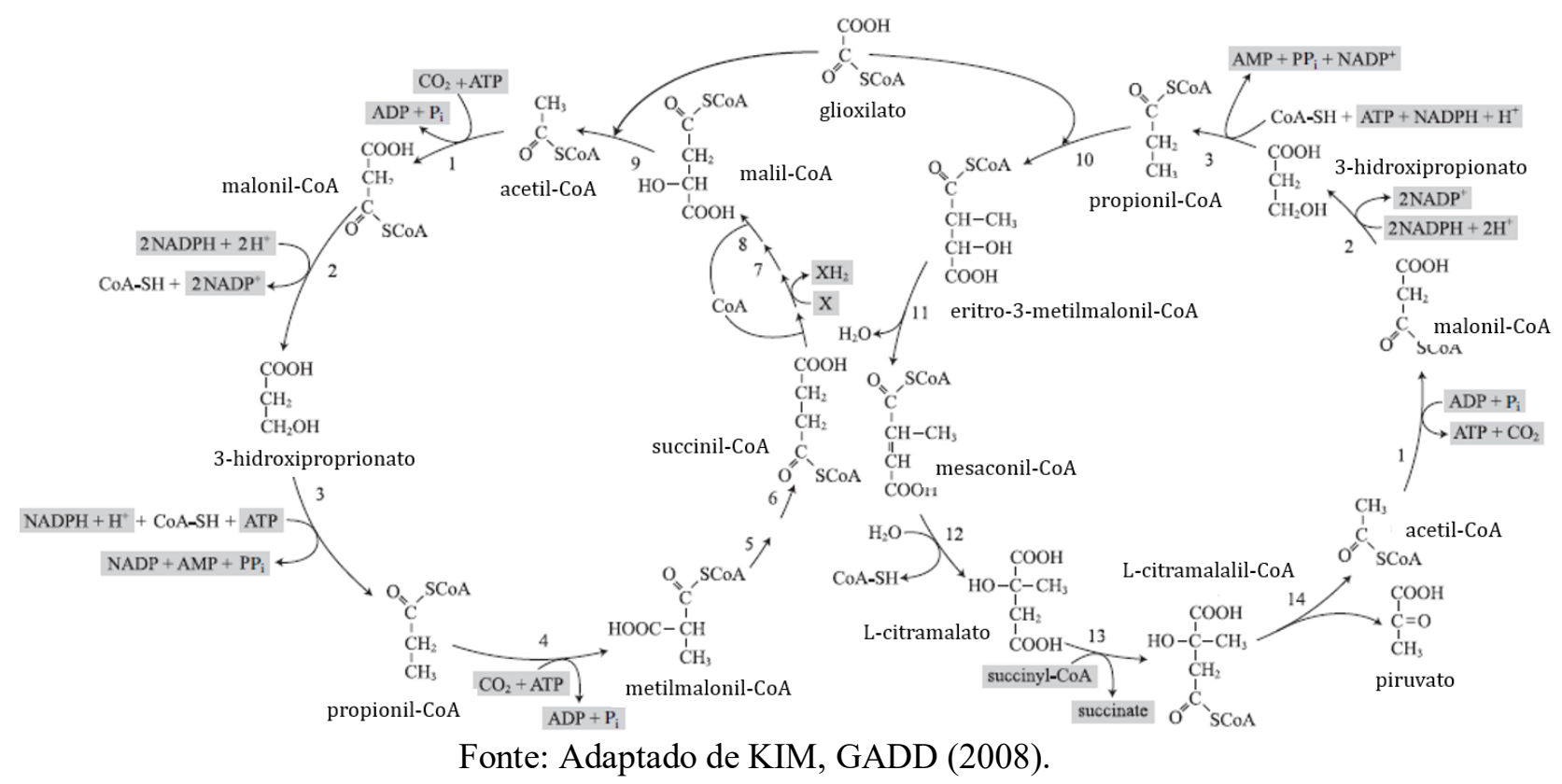

A Tabela 3 apresenta os diferentes mecanismos de assimilação de $\mathrm{CO}_{2}$ em bactérias e as enzimas associadas a fixação de $\mathrm{CO}_{2} / \mathrm{HCO}_{3}{ }^{-}$em cada um dos mecanismos. Ademais, os principais precursores formados em cada uma das rotas também são descritos. Cada um destes precursores é utilizado pela célula bacteriana na síntese de biomassa e demais bioprodutos com valor agregado (KUMAR et al., 2018).

\subsubsection{Bioprodutos da fixação de $\mathrm{CO}_{2}$}

Conforme descrito acima, as bactérias quimioautotróficas, assim como os demais organismos autotróficos, são capazes de assimilar o $\mathrm{CO}_{2}$ e utilizá-lo na síntese de material celular e biomoléculas. Assim, em comparação a tecnologias clássicas como absorção, adsorção e separação por membranas, por exemplo, a fixação biológica de carbono possui a vantagem de resultar não somente na captura de $\mathrm{CO}_{2}$, mas também na produção de produtos com valor comercial (KUMAR et al., 2018). 
Tabela 3 - Mecanismos de fixação de $\mathrm{CO}_{2}$ em bactérias quimioautotróficas e as principais enzimas e precursores envolvidos em cada um destes caminhos.

\begin{tabular}{|c|c|c|}
\hline $\begin{array}{c}\text { Mecanismo } \\
\text { de fixação de } \\
\mathrm{CO}_{2}\end{array}$ & Precursores & $\begin{array}{c}\text { Enzimas } \\
\text { fixadoras de } \mathrm{CO}_{2}\end{array}$ \\
\hline Ciclo de Calvin & $\begin{array}{l}\text { RuBP, sedoheptulose-7-fosfato, } \\
\text { eritrose-4-fosfato, 3-PGA, } \\
\text { gliceraldeído 3-fosfato, F6P, } \\
\text { G6P }\end{array}$ & $\mathrm{RuBisCO}$ \\
\hline Ciclo (rTCA) & Acetil-CoA & $\begin{array}{l}\text { Isocitrato desidrogenase, 2-oxoglutarato } \\
\text { sintase }\end{array}$ \\
\hline Wood-Ljungdahl & Acetil-CoA & $\begin{array}{c}\text { Formato desidrogenase, } \\
\text { CO desidrogenase/acetil-CoA sintase }\end{array}$ \\
\hline Rota 3HP-4HB & Acetil-CoA & $\begin{array}{c}\text { Acetil-CoA carboxilase, propionil-CoA } \\
\text { carboxilase }\end{array}$ \\
\hline Ciclo do DC-4HB & Acetil-CoA & Piruvato sintase, PEP carboxilase \\
\hline Bi-ciclo do 3-HP & Piruvato & $\begin{array}{c}\text { Acetil-CoA carboxilase, propionil-CoA } \\
\text { carboxilase }\end{array}$ \\
\hline
\end{tabular}

Fonte: Adaptado de THAKUR et al. (2018).

Atualmente, diversos materiais e moléculas de uso industrial já tiveram a sua síntese demonstrada em cultivos quimioautotróficos de bactérias. Alguns destes produtos são detalhados a seguir.

a) Biofixação de $\mathrm{CO}_{2}$ e produção de biodiesel:

O biodiesel é um combustível produzido por meio de reações de transesterificação entre triglicerídeos (lipídeos) e álcoois na presença de um ácido ou base como catalisador. Devido ao elevado teor celular de lipídeos, a biomassa de bactérias constitui uma matéria prima ideal para a produção deste biocombustível. De modo geral, os lipídeos, juntamente com os carboidratos e as proteínas, são os principais produtos do metabolismo microbiano de fixação de $\mathrm{CO}_{2}$. Em cepas quimiolitotróficas, por exemplo, os lipídeos podem constituir de $2-60 \%$ da biomassa bacteriana seca, possibilitando grandes produtividades de biodiesel (THAKUR et al., 2018; KUMAR et al., 2018).

b) Biofixação de $\mathrm{CO}_{2}$ e produção de biossurfactantes: 
Muitas espécies de bactérias são capazes de produzir materiais biologicamente ativos ou biossurfactantes. Estes materiais apresentam propriedades emulsificantes, dispersantes e solubilizantes, podendo ser aplicados em indústrias alimentícias, petroquímicas, farmacêuticas, dentre outras. Em relação aos surfactantes sintéticos, os biossurfactantes são superiores devido a características como biodegradabilidade, baixa toxicidade, estabilidade, maiores especificidades e variedades. Ainda, os biossurfactantes produzidos por microrganismos podem ser de quatro naturezas distintas: 1) glicolipídeos, 2) fosfolipídios, 3) lipopeptídeos e 4) substâncias poliméricas. Dentre estas classes de surfactantes, os glicolipídeos e os lipopeptídeos são os mais estudados, já que degradam substâncias hidrofóbicas e exibem atividades antimicrobianas, respectivamente (THAKUR et al., 2018).

c) Biofixação de $\mathrm{CO}_{2}$ e produção de PHB:

Bactérias autotróficas podem fixar $\mathrm{CO}_{2}$ e utilizá-lo para produzir polihidroxialcanoatos (PHAs). PHAs são biopolímeros biodegradáveis, biocompatíveis e termoestáveis, sendo, desta forma, potenciais substitutos dos plásticos derivados de petróleo. Em bactérias e demais microrganismos, os PHAs são armazenados intracelularmente como materiais de reserva energética, sendo sintetizados por células microbianas quando submetidas a condições de escassez de nitrogênio e/ou fósforo, mas com grande disponibilidade de carbono $\left(\mathrm{CO}_{2}\right)$ (THAKUR et al., 2018; KUMAR et al., 2018; CARDOSO, 2017).

d) Biofixação de $\mathrm{CO}_{2}$ e produção de EPS:

Além de biodiesel, biossurfactantes e biopolímeros, algumas espécies de bactérias quimiolitotróficas produzem substâncias poliméricas extracelulares (EPS). Estas substâncias são produtos do metabolismo bacteriano, sendo secretadas pelas células durante a lise celular ou durante a abundância de carbono $\left(\mathrm{HCO}_{3}{ }^{-} / \mathrm{CO}_{2}\right)$ no meio de cultura. Carboidratos (polissacarídeos) e proteínas são os principais componentes das EPS (75-90\%), que também podem ser formadas por ácidos nucleicos, lipídeos, glicoproteínas, lipopeptídeos e lipopolissacarídeos (MORE et al., 2014). Devido à sua composição, as EPS apresentam propriedades como biodegradabilidade, biocompatibilidade, hidrofobicidade/hidrofilicidade e capacidade adsortiva, podendo ser empregadas como biofloculantes, biossurfactantes, detergentes, aditivos alimentares e farmacêuticos, dentre outros (KUMAR et al., 2018; MORE et al., 2014). 
Ainda, algumas cepas quimiotróficas podem ser geneticamente modificadas a fim de produzir compostos de elevado valor agregado. Etanol, butanol, glicerol, ácidos orgânicos, hidrocarbonetos (alcanos e alcenos), açúcares e terpenos são alguns dos produtos que podem ser sintetizados por microrganismos autotróficos mediante modificações genéticas (SALEHIZADEH, YAN, FARNOOD, 2020). 


\section{MATERIAIS E MÉTODOS}

A metodologia adotada para a obtenção e caracterização de bactérias quimioautotróficas a partir de sedimentos marinhos antárticos compreendeu quatro estágios, sendo:

$1^{\circ}$ ) obtenção e pré-tratamento de amostras para o isolamento bacteriano (Seção 4.1);

$2^{\circ}$ ) enriquecimento, isolamento, seleção e cultivo de bactérias quimioautotróficas (Seção 4.2);

$3^{\circ}$ ) identificação da cepa quimioautotrófica de maior crescimento (Seção 4.3);

$4^{\circ}$ ) caracterização do crescimento quimioautotrófico da cepa identificada (Seção 4.4);

O fluxograma da Figura 13 resume a metodologia empregada. As próximas seções irão detalhar os materiais e métodos utilizados em cada um dos estágios elencados acima.

Figura 13 - Fluxograma resumindo a metodologia desenvolvida no presente trabalho.

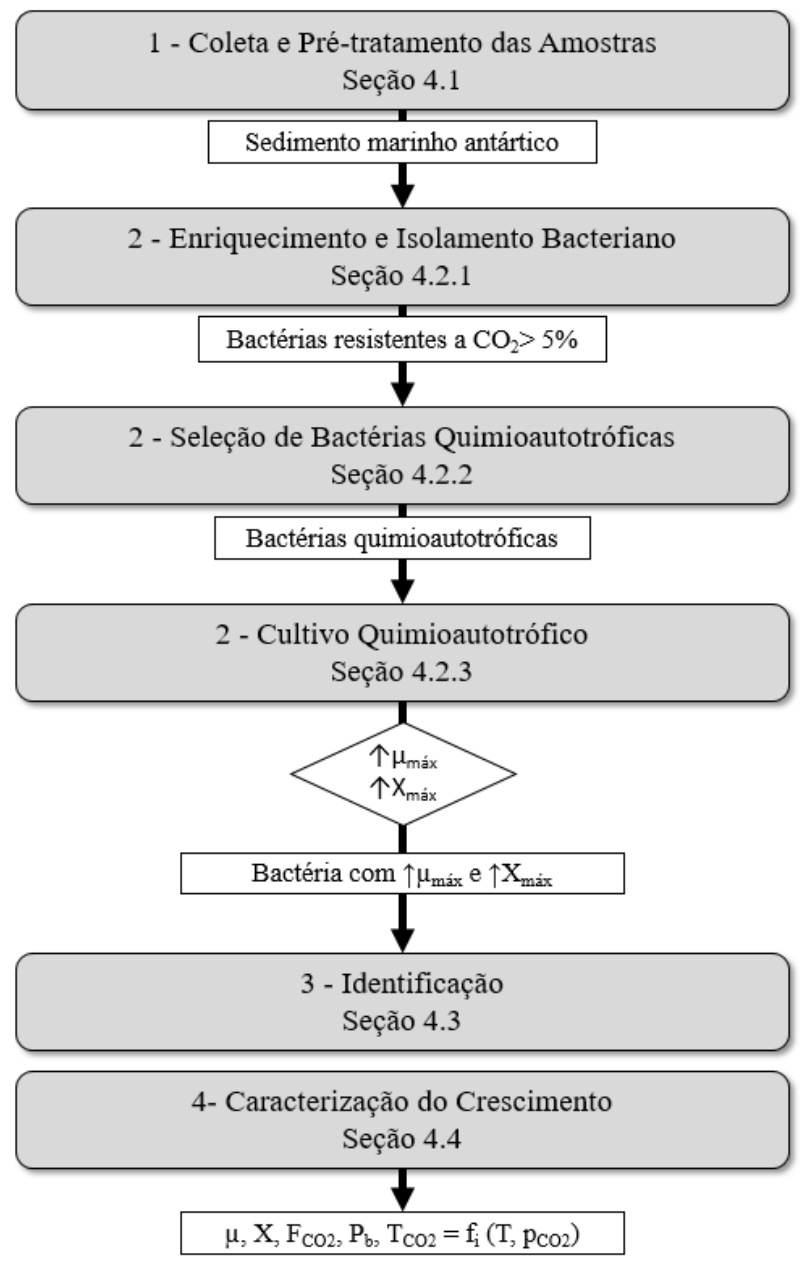




\subsection{AMOSTRAS PARA O ISOLAMENTO BACTERIANO}

O isolamento bacteriano foi realizado a partir de sedimentos marinhos coletados no Estreito de Bransfield, Antártica, e cedidos pelo Laboratório de Geologia Marinha da Universidade Federal Fluminense (LAGEMAR-UFF). O ponto de coleta dos sedimentos,

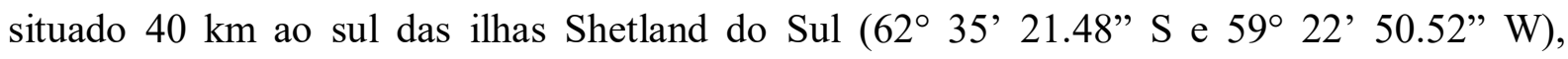
encontrava-se a $550 \mathrm{~m}$ de profundidade (Figura 14). Dados obtidos pelo LAGEMAR indicaram que o local de coleta das amostras é caracterizado pela presença de carbono inorgânico e por uma disponibilidade reduzida de carbono orgânico. Ainda, estudos metaproteômicos e metagenômicos demonstram a presença de bactérias quimioautotróficas em sedimentos marinhos e em águas costais da Antártica (WILKINS et al., 2012; CARR et al, 2013; FRANCO et al, 2018). Tais evidências sugerem que os sedimentos utilizados neste trabalho abrigam microrganismos fixadores de $\mathrm{CO}_{2} / \mathrm{HCO}_{3}{ }^{-}$e justificam o seu emprego no presente estudo.

Figura 14 - Ponto de coleta do sedimento utilizado para o isolamento bacteriano.

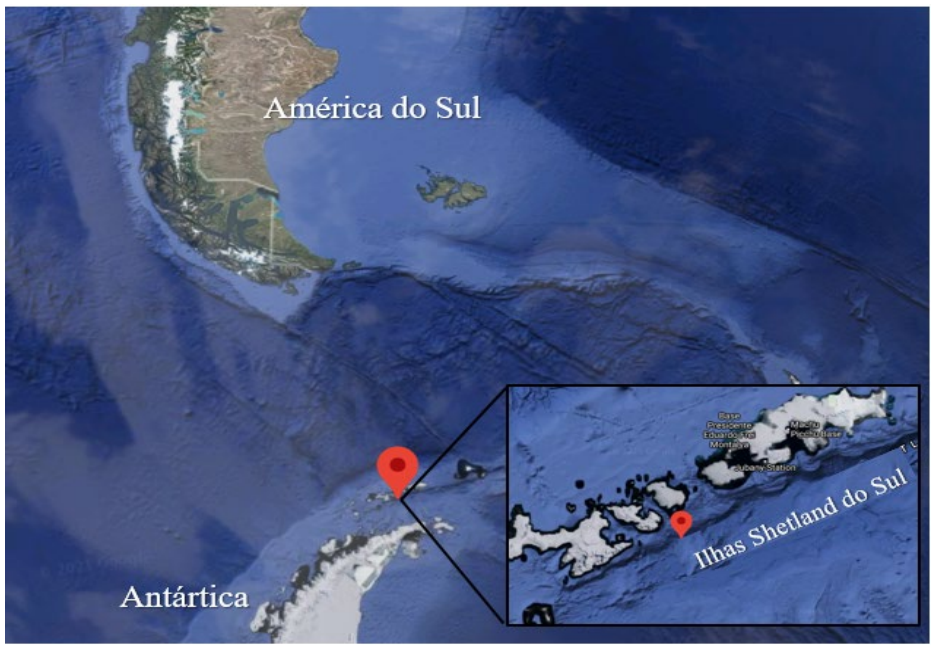

Os sedimentos antárticos foram inicialmente pré-tratados em ambiente estéril. A superfície externa destes foi raspada e removida com o auxílio de espátulas e os sólidos resultantes do processo foram cominuídos, homogeneizados e particionados em amostras com massa média de 0,33 g. As amostras foram pesadas em balança analítica (Shimadzu Corp, AUW220D) e armazenadas em microtubos estéreis. 


\subsection{ENRIQUECIMENTO, ISOLAMENTO, SELEÇÃO E CULTIVO DE BACTÉRIAS QUIMIOAUTOTRÓFICAS}

O estágio de enriquecimento, isolamento e seleção de bactérias quimioautotróficas envolveu três etapas principais, as quais estão descritas nos diagrama da Figura 15 e da Figura 16:

$1^{\text {a) }}$ enriquecimento primário, isolamento e identificação de bactérias aclimatadas a elevadas concentrações de $\mathrm{CO}_{2}(>5 \% \mathrm{v} / \mathrm{v})$;

$2^{a}$ ) seleção e cultivo de espécies quimioautotróficas a partir das cepas isoladas no enriquecimento primário (etapa 1);

$3^{\text {a) }}$ avaliação de parâmetros cinéticos de crescimento das cepas quimioautotróficas obtidas na etapa 2 , e determinação da cepa com maior velocidade de crescimento e maior rendimento em células (crescimento);

\subsubsection{Etapa 1: Enriquecimento e isolamento de bactérias aclimatadas a altas concentrações de $\mathrm{CO}_{2}$}

Bactérias aclimatadas a elevadas concentrações de $\mathrm{CO}_{2}(>5 \% \mathrm{v} / \mathrm{v})$ foram enriquecidas a partir das amostras pré-tratadas de sedimento marinho antártico. As culturas de enriquecimento foram estabelecidas em quatro meios líquidos distintos e mantidas em sistemas de cultivo fechado (batelada). Cada meio de cultura ou meio de enriquecimento foi preparado com uma base de água do mar artificial (ASW) e suplementado com combinações distintas de três possíveis fontes de energia para o metabolismo bacteriano: manitol, tiossulfato de sódio $\left(\mathrm{Na}_{2} \mathrm{~S}_{3} \mathrm{O}_{4}\right)$ e sulfato de amônio $\left(\left(\mathrm{NH}_{4}\right)_{2} \mathrm{SO}_{4}\right)$. A fim de estimular o crescimento de cepas adaptadas à escassez nutricional, nenhum dos quatro meios de enriquecimento foi complementado com vitaminas, fósforo ou quaisquer fontes adicionais de nitrogênio.

Os doadores de elétrons $\mathrm{Na}_{2} \mathrm{~S}_{2} \mathrm{O}_{3}$ e $\left(\mathrm{NH}_{4}\right)_{2} \mathrm{SO}_{4}$ são compostos inorgânicos de baixa toxicidade e foram utilizadas com o objetivo de enriquecer bactérias oxidadoras de enxofre e/ou nitrogênio, comumente encontradas em sedimentos marinhos profundos (HÜGLER, 
SIEVERT, 2011; NCBI, 2020). Ainda, o uso do composto orgânico manitol visou possibilitar o crescimento de cepas quimioautotróficas facultativas, capazes de também utilizar carbono orgânico. Por ocorrer a velocidades superiores, o crescimento alternativo em substratos orgânicos foi desejado a fim de facilitar a rápida obtenção de grandes quantidades de préinóculo. Esta característica é extremamente desejável para aplicações em escala industrial, na qual elevadas vazões de gases de combustão/gás natural precisam ser tratadas.

Figura 15 - Etapas do enriquecimento seletivo primário de bactérias resistentes a elevadas concentrações de $\mathrm{CO}_{2}\left(1^{\mathrm{a}}\right.$ etapa do $2^{\mathrm{o}}$ estágio deste trabalho).

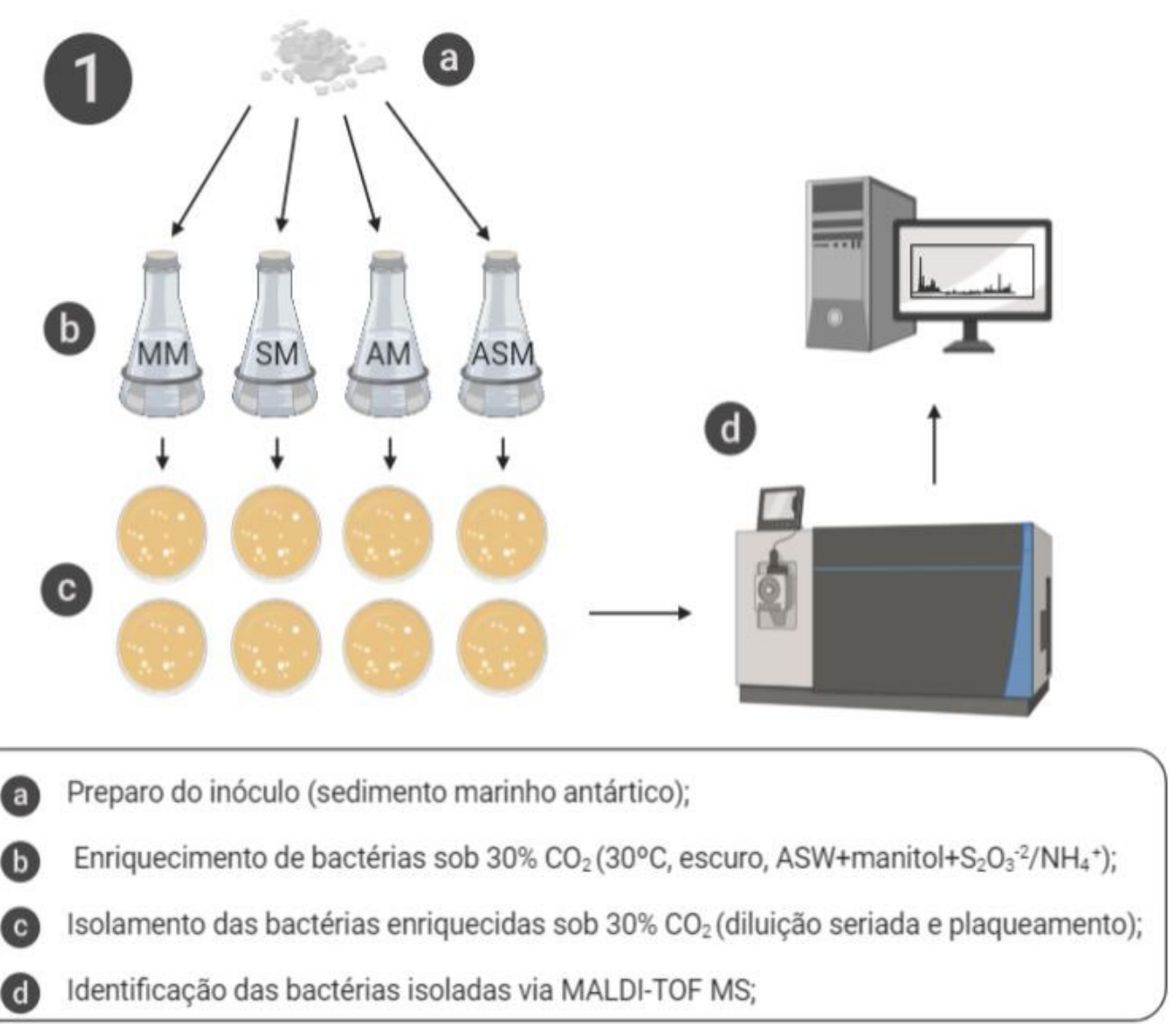

\subsubsection{Meio mineral mínimo (ASW) e meios de enriquecimento}

Conforme descrito, os meios de cultura empregados no enriquecimento primário foram preparados a partir do meio mineral mínimo ASW. Este meio continha, em 11 de água ultrapura (Milli-Q, Merck Milipore), 28,32g de NaCl, 0, $77 \mathrm{~g}$ de $\mathrm{KCl}, 5,48 \mathrm{~g}$ de $\mathrm{MgCl}_{2} \cdot 6 \mathrm{H}_{2} \mathrm{O}, 7,39 \mathrm{~g}$ de $\mathrm{MgSO}_{4} \cdot 7 \mathrm{H}_{2} \mathrm{O}, 1,11 \mathrm{~g}$ de $\mathrm{CaCl}_{2}$ e $2 \mathrm{ml}$ de uma solução de elementos traço. A solução de elementos traço era composta por $\mathrm{FeCl}_{3} \cdot 6 \mathrm{H}_{2} \mathrm{O}, 3,15 \mathrm{~g} / \mathrm{L}$; $\mathrm{Na}_{2} \mathrm{EDTA} \cdot 2 \mathrm{H}{ }_{2} \mathrm{O}, 4,36 \mathrm{~g} / \mathrm{L}$; 
$\mathrm{CuSO}_{4} \cdot 5 \mathrm{H}_{2} \mathrm{O}, 9,8 \mathrm{mg} / \mathrm{L} ; \mathrm{ZnSO}_{4} \cdot 7 \mathrm{H}_{2} \mathrm{O}, 22 \mathrm{mg} / \mathrm{L} ; \mathrm{CoCl}_{2} \cdot 6 \mathrm{H}_{2} \mathrm{O}, 10 \mathrm{mg} / \mathrm{L} ; \mathrm{MnCl}_{2} \cdot 4 \mathrm{H}_{2} \mathrm{O}, 0,18$ $\mathrm{g} / \mathrm{L}$ e $\mathrm{Na}_{2} \mathrm{MoO}_{4} \cdot 2 \mathrm{H}_{2} \mathrm{O}, 6,3 \mathrm{mg} / \mathrm{L}$ (GUILLARD, RYTHER, 1962). Os quatro meios de enriquecimento, nomeados de meio MM, meio AM, meio SM e meio ASM, foram sintetizados segundo as composições da Tabela 4 e esterilizados por filtração à vácuo com membrana de 0,22 $\mu \mathrm{m}$ (MF-Millipore, Merck). Adicionalmente, o $\mathrm{pH}$ inicial dos meios foi ajustado para 6,8.

\subsubsection{Culturas de enriquecimento}

Amostras de 0,33 g de sedimento foram inoculadas em quatro frascos Erlenmeyer de $125 \mathrm{ml}$ (Figura 15a), cada um contendo $30 \mathrm{ml}$ de meio de enriquecimento. Os frascos inoculados foram fechados com rolhas de silicone e os seus volumes foram completos com misturas gasosas de $\operatorname{ar} / \mathrm{CO}_{2}\left(30 \% \mathrm{CO}_{2} \mathrm{v} / \mathrm{v}, 1 \mathrm{~atm}\right)$ (Figura 15b). A injeção de $\mathrm{ar} / \mathrm{CO}_{2}$ nos recipientes de cultura foi realizada utilizando um controlador de fluxo de massa (MKS Instruments) e a uma taxa de $21 /$ min durante $3 \mathrm{~min}$. As culturas de enriquecimento foram incubadas no escuro, a $30^{\circ} \mathrm{C}$, sob atmosfera de $30 \% \mathrm{CO}_{2}$ e agitação de $180 \mathrm{rpm}$ (Infors $\mathrm{HT}$, Multitron). A fase gasosa dos frascos de cultura foi renovada em intervalos de 2 dias.

Tabela 4 - Composição e fontes de energia dos quatro meios de cultura utilizados para o enriquecimento seletivo de bactérias tolerantes a elevadas concentrações de $\mathrm{CO}_{2}$.

\begin{tabular}{ccc}
\hline $\begin{array}{c}\text { Meio de } \\
\text { cultura/enriquecimento }\end{array}$ & Composição & Fontes de energia \\
\hline MM & $\mathrm{ASW}+$ Manitol $(5 \mathrm{~g} / \mathrm{L})$ & Manitol \\
$\mathrm{SM}$ & $\mathrm{ASW}+$ Manitol $(5 \mathrm{~g} / \mathrm{L})+\mathrm{Na}_{2} \mathrm{~S}_{3} \mathrm{O}_{4}(5 \mathrm{~g} / \mathrm{L})$ & Manitol e $\mathrm{Na}_{2} \mathrm{~S}_{3} \mathrm{O}_{4}$ \\
$\mathrm{AM}$ & $\mathrm{ASW}+$ Manitol $(5 \mathrm{~g} / \mathrm{L})+\left(\mathrm{NH}_{4}\right)_{2} \mathrm{SO}_{4}(5 \mathrm{~g} / \mathrm{L})$ & Manitol e $\left(\mathrm{NH}_{4}\right)_{2} \mathrm{SO}_{4}$ \\
& $\mathrm{ASW}+$ Manitol $(5 \mathrm{~g} / \mathrm{L})+\left(\mathrm{NH}_{4}\right)_{2} \mathrm{SO}_{4}(5 \mathrm{~g} / \mathrm{L})$ & Manitol, $\left(\mathrm{NH}_{4}\right)_{2} \mathrm{SO}_{4}$ \\
$\mathrm{ASM}$ & $+\mathrm{Na}_{2} \mathrm{~S}_{3} \mathrm{O}_{4}(5 \mathrm{~g} / \mathrm{L})$ & $\mathrm{Na}_{2} \mathrm{~S}_{3} \mathrm{O}_{4}$ \\
\hline
\end{tabular}

Após 30 dias de incubação e observada turbidez dos meios de cultura, bactérias resistentes a $\mathrm{CO}_{2}$ foram isoladas em meio sólido através do método de diluição seriada (BLAIZE, SUTER, CORBO, 2020).

\subsubsection{Isolamento e cultivo de bactérias em meio sólido}


A fim de obter cepas isoladas, alíquotas de $1 \mathrm{ml}$ de cada um dos meios de cultura foram diluídas consecutivamente em $9 \mathrm{ml}$ de ASW. $100 \mu \mathrm{l}$ das diluições seriadas foram disseminados em meio BHI solidificado com $16 \mathrm{~g} / \mathrm{L}$ de ágar (HiMedia) (Figura 15c). As placas foram incubadas no escuro, a $30^{\circ} \mathrm{C}$ e sob concentração atmosférica de $\mathrm{CO}_{2}(0,04 \%)$. Ao final de $96 \mathrm{~h}$, as diferentes colônias bacterianas estabelecidas no meio sólido foram isoladas e submetidas à identificação por espectrometria de massas.

\subsubsection{Identificação de espécies bacterianas via espectrometria de massas}

Para realizar a identificação das bactérias via espectrometria de massa, amostras das colônias isoladas em meio sólido foram coletadas com auxílio de alças de inoculação estéreis. As amostras foram depositadas em microtubos de $1 \mathrm{ml}$ e inativadas mediante a adição de 300 $\mu \mathrm{l}$ de etanol e $100 \mu \mathrm{l}$ de água deionizada. O conteúdo dos microtubos foi homogeneizado, centrifugado (2 min, $13.400 \mathrm{rpm}$ ) (Eppendorf, MiniSpin), e o sobrenadante descartado. A seguir, $50 \mu \mathrm{l}$ de ácido fórmico (70\%) (AF70) e $50 \mu \mathrm{l}$ de acetonitrila (ACN) foram utilizados para extrair as proteínas contidas nas células bacterianas centrifugadas. A suspensão de AF70, ACN e bactérias foi homogeneizada e centrifugada (13.500 rpm, $2 \mathrm{~min}$ ). 0,6 61 do sobrenadante foram depositados sobre a placa de análise (MTP 384, Bruker Daltonics). Após secagem em temperatura ambiente, o sobrenadante foi coberto por $0,6 \mu 1$ de solução matriz (ácido $\alpha$-ciano4-hidroxicinâmico, HCCA), deixado secar e encaminhado para análise no espectrômetro de massas UltrafleXtreme MALDI-TOF (Bruker Daltonics, Alemanha) (Figura15d).

Os espectros de massa foram adquiridos no modo de operação linear e de íon positivo, sendo posteriormente analisados com o auxílio do banco de dados Biotyper (Bruker Daltonics) e do software aberto mMass (STROHALM, 2020). Com o auxílio do software, os espectros de massa foram convertidos em perfis eletroforéticos correspondentes. Ainda, o tratamento dos espectros através do mMass seguiu a metodologia de Zhu et al. (2016) e a identificação rápida de espécies bacterianas baseou-se na comparação entre os diferentes espectros e os perfis eletroforéticos. Diferentes cepas foram consideradas da mesma espécie ou de espécies similares quando os espectros/perfis eletroforéticos eram idênticos ou semelhantes, segundo comparação realizada no software mMass (KERSTERS et al., 1994). Por fim, os métodos de PCA e análise de clusters foram implementados no software RStudio (v.1.3.1093) e utilizados para confirmar a análise realizada no mMass (ZHU et al., 2016; SAMAD et al., 2020). 


\subsubsection{Etapa 2: Seleção e cultivo de bactérias quimioautotróficas}

As bactérias obtidas no enriquecimento bacteriano foram submetidas a uma etapa de seleção de cepas quimioautotróficas, seguida do seu cultivo em batelada e sob atmosfera de $\mathrm{CO}_{2}$. $\mathrm{Na}$ fase seletiva, as colônias foram cultivadas em meio mineral, no escuro e com $\mathrm{CO}_{2}$ como única fonte de carbono. Posteriormente, as cepas resultantes desta fase foram cultivadas em frascos de maiores volumes. As diferentes etapas de seleção e cultivo de bactérias quimiotróficas são descritas na Figura 16.

Figura 16 - Etapas do processo de seleção e cultivo de bactérias quimioautotróficas a partir das cepas isoladas no processo de enriquecimento de bactérias resistentes ao $\mathrm{CO}_{2}$. A etapa e) corresponde às Seções 4.3 e 4.4 .

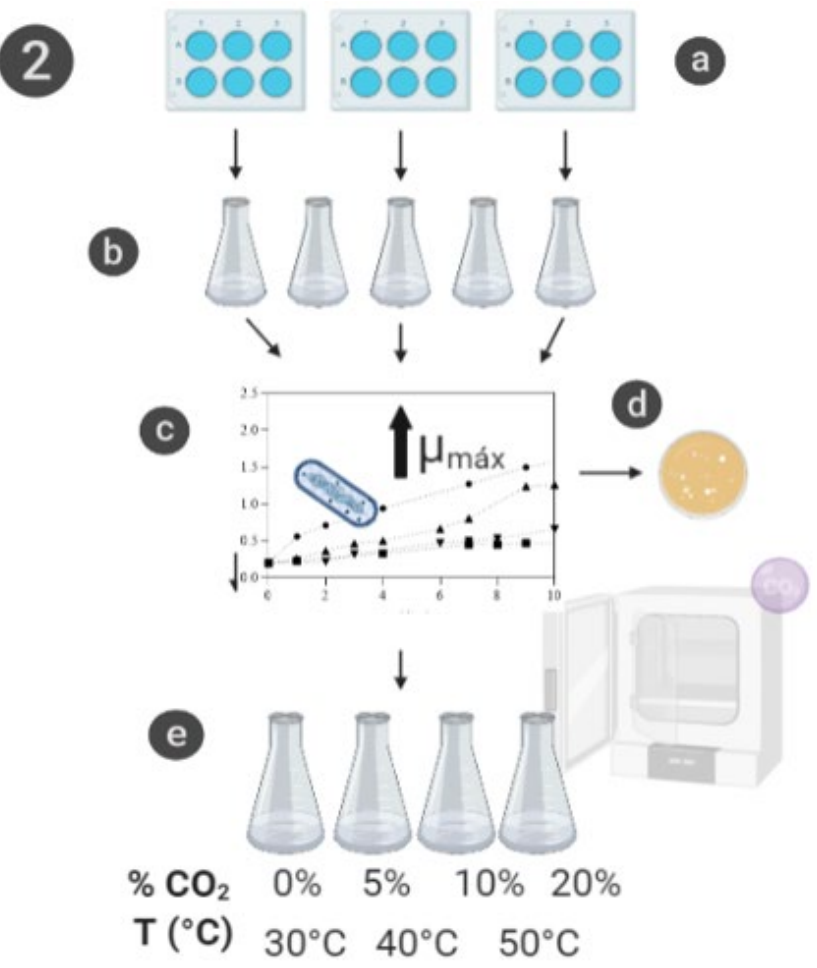

a Seleção de cepas quimioautotróficas $\left(20 \% \mathrm{CO}_{2}, 30^{\circ} \mathrm{C}\right.$, escuro, $3 \mathrm{ml}$ meio mineral);

b Cultivo de bactérias quimioautotróficas em $50 \mathrm{ml}$ meio mineral $\left(20 \% \mathrm{CO}_{2}, 30^{\circ} \mathrm{C}\right.$, escuro);

C Seleção da cepa com maior velocidade de crescimento e concentração celular;

d Verificação da pureza da cultura;

e Identificação e caracterização da cepa selecionada sob diferentes $\% \mathrm{CO}_{2}$ e T $\left({ }^{\circ} \mathrm{C}\right)$;

\subsubsection{Meios de cultura seletivos}


As bactérias enriquecidas foram inoculadas em diferentes meios seletivos, cujas composições dependeram do meio de cultura utilizado no enriquecimento primário de cada cepa. Desta maneira, bactérias isoladas a partir do meio $\mathrm{AM}\left(\mathrm{ASW}+\left(\mathrm{NH}_{4}\right)_{2} \mathrm{SO}_{4}+\right.$ manitol), por exemplo, foram inoculadas em meio composto somente por ASW e $\left(\mathrm{NH}_{4}\right)_{2} \mathrm{SO}_{4}$. Para cada cepa avaliada na fase de seleção, grupos controle foram cultivados em meios de cultura enriquecidos com carbono orgânico (ASW+manitol, $5 \mathrm{~g} / \mathrm{L}$, ou acetato de sódio, $5 \mathrm{~g} / \mathrm{L}$ ). Ainda, os meios que não apresentavam fontes de $\mathrm{N}$ na sua composição inicial foram suplementados com $\mathrm{NaNO}_{3}(1,8$ g/L). A Tabela 5 resume os meios seletivos empregados na seleção de bactérias quimioautotróficas.

Tabela 5 - Composição dos meios utilizados na seleção de cepas quimioautotróficas. Cada meio foi preparado com base nos meios de cultura MM, SM, AM e ASM, originalmente empregados na etapa de enriquecimento de bactérias resistentes a $\mathrm{CO}_{2}$.

\begin{tabular}{ccc}
\hline $\begin{array}{c}\text { Meio seletivo } \\
\text { (sem manitol) }\end{array}$ & $\begin{array}{c}\text { Meio de } \\
\text { enriquecimento }\end{array}$ & Composição do meio seletivo \\
\hline $\mathrm{A}$ & $\mathrm{AM}$ ou M & $\mathrm{ASW}+\left(\mathrm{NH}_{4}\right) \mathrm{SO}_{4}(5 \mathrm{~g} / \mathrm{L})+\mathrm{KH}_{2} \mathrm{PO}_{4}(0,03 \mathrm{~g} / \mathrm{L})$ \\
$\mathrm{S}$ & $\mathrm{SM}$ ou M & $\mathrm{ASW}+\mathrm{Na}_{2} \mathrm{~S}_{3} \mathrm{O}_{4}(5 \mathrm{~g} / \mathrm{L})+\mathrm{KH}_{2} \mathrm{PO}_{4}(0,03 \mathrm{~g} / \mathrm{L})+\mathrm{NaNO}_{3}$ \\
& & $(1,8 \mathrm{~g} / \mathrm{L})$ \\
$\mathrm{AS}$ & $\mathrm{ASM}$ & $\mathrm{ASW}+\left(\mathrm{NH}_{4}\right)_{2} \mathrm{SO}_{4}(5 \mathrm{~g} / \mathrm{L})+\mathrm{Na}_{2} \mathrm{~S}_{3} \mathrm{O}_{4}(5 \mathrm{~g} / \mathrm{L})+\mathrm{KH}_{2} \mathrm{PO}_{4}$ \\
& & $(0,03 \mathrm{~g} / \mathrm{L})$ \\
\end{tabular}

\subsubsection{Preparo dos inóculos em meio líquido}

O preparo dos inóculos utilizados na seleção de bactérias quimioautotróficas foi realizado a partir das cepas isoladas em meio sólido (Figura16c). As colônias crescidas nas placas de BHI foram transferidas para microtubos preenchidos com $500 \mu \mathrm{l}$ de ASW. A suspensão resultante foi homogeneizada e centrifugada a $13.400 \mathrm{rpm}$ por $2 \mathrm{~min}$. O sobrenadante foi descartado e o pellet bacteriano foi ressuspenso em $500 \mu$ de ASW fresca. Esta etapa de lavagem foi repetida outras duas vezes a fim de remover qualquer traço de carbono orgânico aderido ao pellet. Por fim, foram preservados dois microtubos de inóculo para cada cepa bacteriana.

\subsubsection{Seleção das espécies quimioautotróficas}

As culturas de seleção foram realizadas em placas de cultura celular de 6 poços e mantidas em incubadora de $\mathrm{CO}_{2}$ (Panasonic, Incubadora MCO-19AIC UV), no escuro, sem 
agitação, a $30^{\circ} \mathrm{C}$ e a $20 \% \mathrm{CO}_{2}$ (Figura 16a). Cada um dos poços recebeu 2,5 $\mathrm{ml}$ de meio mineral estéril e $500 \mu 1$ do inóculo preparado previamente. Os cultivos e inóculos dos grupos controle foram mantidos sob estas mesmas condições, assim como sob atmosfera ambiente $(0,04 \%$ $\mathrm{CO}_{2}$ ). Após 7 dias, as culturas quimioautotróficas visualmente turvas foram incubadas em frascos de maior volume.

\subsubsection{Cultivo das espécies quimioautotróficas selecionadas}

Alíquotas de $2 \mathrm{ml}$ das culturas crescidas sob condições de quimioautotrofia foram inoculadas em frascos Erlenmeyers de $125 \mathrm{ml}$ (Figura 16b). Meios minerais frescos (48 ml) foram adicionados aos recipientes de cultura conforme a Tabela 5. Os frascos foram fechados com rolhas de algodão permeáveis e incubados por 10-21 dias no escuro, sem agitação, a $30^{\circ} \mathrm{C}$ e a $20 \% \mathrm{CO}_{2}$ (Panasonic, Incubadora MCO-19AIC UV). A pureza das culturas foi verificada através do método de diluição seriada e plaqueamento em meio sólido (Figura 16d). Quando necessário, a identificação via MALDI-TOF MS foi novamente realizada.

O crescimento dos cultivos e concentração celular dos mesmos foi quantificado através da densidade ótica (DO) (STEVENSON et al., 2016). Para tanto, amostras das culturas foram coletadas a cada 2 dias e as suas DOs foram medidas em espectrofotômetro de UV-visível (Shimadzu UV-2600) no comprimento de onda de $600 \mathrm{~nm}$.

\subsubsection{Etapa 3: Avaliação de parâmetros cinéticos de crescimento e seleção de cepa para posterior caracterização}

A partir dos dados estimados de concentração celular, curvas de crescimento de DO em função do tempo foram obtidas para cada um dos cultivos realizados. Os parâmetros cinéticos de velocidade máxima de crescimento $\left(\mu_{\text {máx }}\right)$ e de máxima densidade ótica $\left(\mathrm{DO}_{\text {máx }}\right)$ foram determinados para cada curva e comparados entre si. A cepa que apresentou maiores valores de $\mu_{\text {máx }}$ e $\mathrm{DO}_{\text {máx }}$ foi selecionada para posterior identificação e caracterização (Figura 16e). Adicionalmente, as diferentes bactérias obtidas ao final dos processos de enriquecimento e seleção foram estocadas em glicerol $(50 \%)$ e mantidas sob refrigeração $\left(-20^{\circ} \mathrm{C}\right)$. 


\subsection{IDENTIFICAÇÃO DA CEPA SELECIONADA ATRAVÉS DE SEQUENCIAMENTO DE 16s rDNA}

A cepa quimioautotrófica selecionada nos estágios de enriquecimento, isolamento e seleção foi identificada via sequenciamento de $16 \mathrm{~S}$ rDNA, conduzido em laboratório externo (BPI Biotecnologia). A extração de DNA total das amostras foi realizado com o Kit Fungal/Bacterial DNA MiniPrep ${ }^{\mathrm{TM}}$ (D6005, Zymo Research), seguindo o protocolo descrito pelo fabricante (ZYMO, 2021). Após extração, os fragmentos de DNA das regiões ITS e 16S foram amplificados via PCR, sendo utilizados os primers forward/reverse ITS5/ITS4 e 8F/1492R, respectivamente (Tabela 6).

Tabela 6 - Genes amplificados e primes utilizados no presente estudo.

\begin{tabular}{cccl}
\hline Gene & Primer & Sequência (5'-3') & Direção \\
\hline \multirow{2}{*}{ ITS } & ITS5 & GGAAGTAAAAGTCGTAACAAGG & Forward \\
& ITS4 & TCCTCCGCTTATTGATATGC & Reverse \\
\multirow{2}{*}{$16 \mathrm{~S}$} & $8 \mathrm{~F}$ & AGAGTTTGATCCTGGCTCAG & Forward \\
& $1492 \mathrm{R}$ & GGTTACCTTGTTACGACTT & Reverse \\
\hline
\end{tabular}

Fonte: RAJA et al., 2017; CHEN et al., 2015.

As reações de PCR foram realizadas em um volume final de $20 \mu \mathrm{L}$, contendo $10 \mu \mathrm{L}$ de GoTaq ${ }^{\circledR}$ Colorless Master Mix 2x (Promega, USL), 0.6 $\mu \mathrm{M}$ de oligonucleotideo foward, $0.6 \mu \mathrm{M}$ de oligonucleotideo reverse e 40ng de DNA genômico. O volume final foi completado com a adição de água ultrapura estéril. O programa de amplificação foi conduzido em termociclador Veriti ${ }^{\mathrm{TM}}$ Thermal Cycler (Applied Biosystems) e consistiu em desnaturação inicial a $95^{\circ} \mathrm{C}$ por $5 \mathrm{~min}$, seguida de 30 ciclos de desnaturação a $95^{\circ} \mathrm{C}$ por $30 \mathrm{~s}$, anelamento a $56^{\circ} \mathrm{C}$ por $40 \mathrm{~s}$, extensão a $72^{\circ} \mathrm{C}$ por 1 min e extensão final a $72^{\circ} \mathrm{C}$ por $5 \mathrm{~min}$. A qualidade do DNA amplificado foi avaliada em gel contendo $2 \%(\mathrm{~m} / \mathrm{v})$ de agarose e corados com UniSafe Dye. Posteriormente, as amostras de PCR foram purificadas com Agencourt AMPure XP (Beckman Coulter, Inc.) e quantificadas por fluorescência em aparelho Qubit (ThermoFhischer).

As reações de sequenciamento foram realizadas utilizando o kit BigDye ${ }^{\circledR}$ Terminator v3.1 Cycle Sequencing Kit (Apllied Biosystems) e a precipitação por etanol/EDTA/acetato de 
sódio. O sequenciamento automático das amostras, por sua vez, foi desempenhado através de eletroforese capilar no equipamento ABI3730xl DNA Analyzer (Applied Biosystems). Os eletroferogramas obtidos foram analisados com os softwares Chromas Lite e Geneious 4.8.3 e a sequência resultante foi então comparada com o banco de dados GenBank através da ferramenta BLAST.

\subsection{CARACTERIZAÇÃO DA CEPA QUIMIOAUTOTRÓFICA SELECIONADA}

A caracterização da cepa selecionada envolveu investigar o seu crescimento e a sua capacidade de fixar carbono em condições ( $\mathrm{T}$ e $\mathrm{p}_{\mathrm{CO} 2}$ ) semelhantes às encontradas industrialmente (e.g., gás natural bruto/pré-tratado e gás de combustão). Para tanto, os ensaios foram realizados em batelada e avaliaram as curvas de crescimento da bactéria a $30^{\circ} \mathrm{C}$ e sob atmosferas de $0 \%, 5 \%, 10 \%$ e $20 \% \mathrm{v} / \mathrm{v}$ de $\mathrm{CO}_{2}(1 \mathrm{~atm})$, e a $10 \% \mathrm{v} / \mathrm{v} \mathrm{CO}_{2}$ e temperaturas de $30^{\circ} \mathrm{C}, 40^{\circ} \mathrm{C}$ e $50^{\circ} \mathrm{C}(1 \mathrm{~atm})$. Adicionalmente, investigou-se o consumo de tiossulfato como fonte de energia e o uso de nitrato $\left(\mathrm{NO}_{3}^{-}\right)$como possível aceptor de elétrons. O fornecimento de nutrientes (vitaminas, elementos traço e P) foi restrito.

\subsubsection{Crescimento bacteriano em diferentes concentrações de $\mathrm{CO}_{2}$ e temperatura fixa}

\subsubsection{Pré- inóculo}

Previamente aos ensaios, culturas foram desenvolvidas visando aumentar o número de células viáveis nos inóculos e assim reduzir a duração da fase lag nos cultivos. Inóculos (200 $\mu 1)$ da bactéria selecionada e estocada a $-20^{\circ} \mathrm{C}$ foram espalhados em placas de $\mathrm{BHI}$ e incubados no escuro, a $30^{\circ} \mathrm{C}$ e sem suplemento de $\mathrm{CO}_{2}$. Ao final de $48 \mathrm{~h}$, a bactéria foi removida do meio sólido e transferida para tubos falcon $(50 \mathrm{ml})$ contendo $15 \mathrm{ml}$ de meio seletivo. Os tubos inoculados foram mantidos ventilados em incubadora de $\mathrm{CO}_{2}$, a $30^{\circ} \mathrm{C}$ e nas mesmas concentrações de $\mathrm{CO}_{2}$ utilizadas nos ensaios ( $0 \%, 5 \%, 10 \%$ ou 20\%). Após $24 \mathrm{~h}$ de cultivo, o pré-inóculo foi lavado com ASW e centrifugado por 10 min à $13.500 \mathrm{rpm}$ (Hitachi, CR22N). 
O inóculo utilizado nos ensaios foi produzido a partir da ressuspensão deste pellet em $15 \mathrm{ml}$ de meio seletivo.

\subsubsection{Cultivo em batelada sob diferentes concentrações de $\mathrm{CO}_{2}$}

Os cultivos empregados em cada concentração de $\mathrm{CO}_{2}$ avaliada foram realizados em triplicata. Frascos de cultura $(125 \mathrm{ml})$ contendo $50 \mathrm{ml}$ de meio seletivo $\mathrm{S}$ foram inoculados e suplementados com $0,1 \mathrm{ml}$ da solução de elementos traço. A DO inicial em todos os ensaios foi padronizada $\left(\mathrm{DO}_{0}=0,145\right)$. Os frascos foram fechados com rolhas de algodão e incubados no escuro, sem agitação, a $30^{\circ} \mathrm{C}$ e sob diferentes concentrações de $\mathrm{CO}_{2}: 0 \%, 5 \%, 10 \%$ e $20 \%$ (Panasonic, Incubadora MCO-19AIC UV). O crescimento bacteriano foi acompanhado através de medidas de DO, coletadas diariamente ao longo de 10 dias. As curvas de crescimento em biomassa $(\mathrm{g} / \mathrm{L})$ foram obtidas a partir de curva de calibração entre $\mathrm{DO}$ e peso seco. $\mathrm{O}$ pH inicial dos meios de cultura foi ajustado para 6,8 .

\subsubsection{Crescimento bacteriano em diferentes temperaturas e concentração de $\mathrm{CO}_{2}$ fixa}

O pré-inóculo e os ensaios a diferentes temperaturas foram realizados de modo semelhante ao já descrito para os experimentos sob diferentes concentrações de $\mathrm{CO}_{2}$ (Seção 4.4.1.1 e Seção 4.4.1.2). A influência da temperatura de cultivo no crescimento da cepa M1BS foi avaliada a $30^{\circ} \mathrm{C}, 40^{\circ} \mathrm{C}$ e $50^{\circ} \mathrm{C}$ e sob atmosfera contendo $\mathrm{CO}_{2} 10 \% \mathrm{v} / \mathrm{v}$ (1 atm). Conforme mencionado anteriormente, estas temperaturas foram selecionadas com o objetivo de simular as condições térmicas dos gases de exaustão industriais e do gás natural bruto/pré-processado (SAYARI et al., 2011; NASCIMENTO, 2012). Desta forma, para esta etapa do estudo, a aclimatação dos inóculos foi desenvolvida sob concentração constante de $\mathrm{CO}_{2}\left(10 \% \mathrm{CO}_{2} \mathrm{v} / \mathrm{v}\right)$ e nas temperaturas adotadas em cada um dos respectivos experimentos $\left(30^{\circ} \mathrm{C}, 40^{\circ} \mathrm{C}\right.$ ou $\left.50^{\circ} \mathrm{C}\right)$. Ainda, para cada condição térmica avaliada, curvas de crescimento (DO e biomassa) foram determinadas ao longo de 10 dias de cultivo.

\subsubsection{Curvas de crescimento em biomassa e medida de massa seca}


As curvas de crescimento em biomassa $(\mathrm{g} / \mathrm{L})$ foram construídas a partir das medidas de DO e da curva de correlação/calibração entre peso seco e DO. Os dados de peso seco foram determinados com base na metodologia descrita por Bernardez e Lima (2015). Membranas filtrantes de 0,22 $\mu \mathrm{m}$ (MF-Millipore, Merck) foram previamente secas em micro-ondas (10 min, potência média) e pesadas em balança analítica. As membranas secas foram posicionadas em um sistema de filtração a vácuo, no qual amostras de $10 \mathrm{ml}$ de meios de cultura foram filtradas. As amostras filtradas possuíam diferentes densidades óticas, previamente estimadas. Após o fim da filtração e obtenção de sólidos úmidos sobre a membrana, esta foi novamente seca em micro-ondas (10 min, potência média) e pesada. O peso seco $\left(\mathrm{M}_{\mathrm{s}} \mathrm{g}\right)$ e a concentração celular $(\mathrm{X}, \mathrm{g} / \mathrm{L})$ foram então calculados com os dados de peso inicial e final da membrana $\left(\mathrm{M}_{\mathrm{i}}\right.$ e $\left.\mathrm{M}_{\mathrm{f}}, \mathrm{g}\right)$ e volume filtrado (V, l) (Equação 4). A curva de correlação entre biomassa (X) e DO encontrase no APÊNDICE A.

$$
X=\frac{M_{f}-M_{i}}{V}=\frac{M_{s}}{V}
$$

\subsubsection{Parâmetros cinéticos de crescimento}

As velocidades máximas de crescimento, $\mu_{\text {máx }}$, foram determinadas através do ajuste de modelos sigmoidais às curvas de crescimento. Para tanto, os modelos de crescimento ${ }^{1}$ Gompertz Modificado, Logístico Modificado e tipo Potência foram empregados (ZWIETERING, M.H. et al., 1990; CORRADINI, PELEG, 2005; LONGHI et al., 2017). Ademais, o valor de $\mu_{\text {máx }}$ também foi estimado por meio da regressão linear da fase exponencial do crescimento, compreendida entre os instantes $t_{\text {exp, } i}$ e $t_{\text {exp,f }}$ e representada matematicamente na Equação 5 (DORAN, 1995).

$$
y=\ln \left(\frac{x}{\mathrm{x}_{\text {exp }, i}}\right)=\mu_{\text {máx }}\left(\mathrm{t}-t_{\text {exp }, i}\right)=\mu_{\text {máx }} t+B, \quad t_{\text {exp }, i}<t<t_{\text {exp }, f}
$$

Previamente ao ajuste dos modelos considerados, as curvas de crescimento foram estabelecidas em termos do logaritmo natural da concentração celular normalizada ( $\mathrm{y}=\mathrm{ln}$ $\left(\mathrm{X} / \mathrm{X}_{0}\right)$ ). Ainda, segundo método descrito em Zwietering et al. (1990), o presente trabalho

1 Os modelos de crescimento utilizados descreveram apenas o número de organismos e não incluem o consumo de substrato. Assim, o seu uso parte da hipótese de que a concentração de substratos é suficiente para que o cultivo se desenvolva até atingir uma densidade intolerável de células (ZWIETERING et al., 1990). 
modificou a equação de crescimento tipo Potencia a fim de incorporar o parâmetro $\mu_{\text {máx }}$ diretamente no modelo.

A regressão linear da fase de crescimento exponencial foi desenvolvida no software estatístico Graphpad Prism 8.0.1, enquanto os parâmetros dos modelos de crescimento sigmoidal foram estimados com o método de mínimos quadrados não linear implementado no software Excel. Neste, a ferramenta de otimização Solver, com o método GRG não linear, foi utilizada para minimizar a soma dos erros quadráticos. A qualidade dos ajustes lineares e nãolineares foi avaliada mediante o cálculo da Raiz do Erro Quadrático Médio (RSME), do Critério de Informação de Akaike Corrigido $\left(\mathrm{AIC}_{\mathrm{c}}\right)$ e do Coeficiente de Determinação $\left(\mathrm{R}^{2}\right)$, quando aplicável (WAGENMAKERS, FARRELL, 2004).

A Tabela 7 apresenta os diferentes modelos utilizados no presente trabalho. As equações a serem ajustadas apresentam parâmetros com relevância cinética, incluindo $\mu_{\text {máx }}, \lambda$ (duração da fase lag) e $A$ (valor de $\ln \left(\mathrm{X} / \mathrm{X}_{0}\right)$ quando $\mu$ torna-se nula), e parâmetros empíricos sem significado microbiológico $\left(t_{c}, n\right.$ e $\left.B\right)$.

Tabela 7 - Modelos utilizados para descrever a curva de crescimento e obter o parâmetro de velocidade máxima de crescimento $\left(\mu_{\text {máx }}\right)$.

\begin{tabular}{|c|c|c|}
\hline Modelo de crescimento & Equação* & Parâmetros \\
\hline Logístico Modificado & $y=\ln \left(\frac{\mathrm{X}}{\mathrm{X}_{0}}\right)=\frac{A}{1+\exp \left[\frac{4 \mu_{\text {máx }}}{A}\left(t_{c}-t\right)\right]}-\frac{A}{1+\exp \left(\frac{4 \mu_{\text {máx }} t_{c}}{A}\right)}$ & $\mu_{\text {máx }}, t_{c}, A$ \\
\hline Gompertz Modificado & $y=\ln \left(\frac{\mathrm{X}}{\mathrm{X}_{0}}\right)=A \exp \left\{-\exp \left[\frac{\mu_{\text {máx }} e}{\lambda}(\lambda-t)+1\right]\right\}$ & $\mu_{\text {máx }}, \lambda, A$ \\
\hline $\begin{array}{c}\text { Crescimento tipo } \\
\text { Potência Modificado }\end{array}$ & $y=\ln \left(\frac{\mathrm{X}}{\mathrm{X}_{0}}\right)=\frac{A t^{n}}{\left[\frac{A(n-1)^{\left(\frac{n-1}{n}\right)}(n+1)^{\left(\frac{n+1}{n}\right)}}{4 n \mu_{\text {máx }}}\right]^{n}+t^{n}}$ & $\mu_{\text {máx }}, n, A$ \\
\hline $\begin{array}{l}\text { Regressão Linear }^{* *} \text { (fase } \\
\text { exponencial) }\end{array}$ & $y=\ln \left(\frac{\mathrm{x}}{\mathrm{x}_{\text {exp, }}}\right)=\mu_{\text {máx }} t-B^{* * *}$ & $\mu_{m a ́ x}, B$ \\
\hline
\end{tabular}

$\mathrm{X}(\mathrm{t})$ ou $\mathrm{X}$ representa a concentração de biomassa no instante $\mathrm{t}$ de crescimento e $\mathrm{X}_{0}$ corresponde à concentração de biomassa inicial $(\mathrm{t}=0)$.

** Válida entre os instantes iniciais $\left(t_{\text {exp, }}\right)$ e finais $\left(t_{\text {exp }, f}\right)$ da fase de crescimento exponencial.

${ }^{* * *} \mathrm{X}_{\text {exp,i }}$ corresponde à concentração celular no instante $\mathrm{t}_{\mathrm{exp}, \mathrm{i}}$ (início do crescimento exponencial).

\subsubsection{Fixação de $\mathrm{CO}_{2}$ e produtividade em biomassa}

A quantidade de carbono fixada durante o crescimento sob diferentes condições de cultivo foi estimada com base em medidas de carbono orgânico total (TOC), consoante apresentado em Bae et al. (2001) e Hu et al. (2010). Três alíquotas de $10 \mathrm{ml}$ de bactérias em 
suspensão foram coletadas durante a fase estacionária de crescimento e mantidas em tubos falcon de $15 \mathrm{ml}$. A seguir, o volume coletado foi centrifugado à $13.500 \mathrm{rpm}$ por $10 \mathrm{~min}$ e o meio sobrenadante foi vertido em um novo tubo. As bactérias centrifugadas foram então lavadas com ASW por duas vezes e ressuspensas em $10 \mathrm{ml}$ de água ultrapura, de modo a manter a mesma concentração celular das amostras. Os tubos contendo o sobrenadante e as bactérias ressuspensas foram armazenados a $-20^{\circ} \mathrm{C}$ durante $24 \mathrm{~h}$, a fim promover a inativação das células bacterianas. O TOC da suspensão de bactérias e do meio de cultura foi então analisado em analisador de Carbono Orgânico Total (Shimadzu, TOC 5000A) (APÊNDICE A). A fração mássica ou teor de carbono nas bactérias $\left(\mathrm{C}_{\mathrm{b}}\right)$ foi determinada a partir do TOC $\left(\mathrm{TOC}_{\mathrm{sb}}, \mathrm{g} / \mathrm{L}\right)$ e da concentração celular $\left(\mathrm{X}_{\mathrm{sb}}, \mathrm{g} / \mathrm{L}\right)$ da suspensão bacteriana, conforme a Equação 6.

$$
C_{b}(\%)=\frac{T O C_{s b}}{X_{s b}} \times 100 \%
$$

O teor de carbono na célula bacteriana foi considerado constante ao longo do crescimento das culturas. A quantidade aproximada de $\mathrm{CO}_{2}$ fixada em biomassa, $\mathrm{F}_{\mathrm{CO}_{2}}(\mathrm{~g} / \mathrm{L})$, foi obtida da Equação 7 e utilizando a concentração celular inicial das culturas $\left(\mathrm{X}_{0}, \mathrm{~g} / \mathrm{L}\right)$, a concentração celular em um instante $t$ de incubação $(X(t)$ ou $X, g / L)$, o teor de carbono celular $\left(\mathrm{C}_{\mathrm{b}}, \mathrm{g} / \mathrm{g}\right)$, a massa molecular do $\mathrm{CO}_{2}\left(\mathrm{M}_{\mathrm{CO} 2}, 44 \mathrm{~g} / \mathrm{mol}\right)$ e a massa atômica do carbono $\left(\mathrm{M}_{\mathrm{c}}, 12\right.$ $\mathrm{g} / \mathrm{mol})$. Ainda, a taxa de fixação de $\mathrm{CO}_{2}$ em biomassa, $\mathrm{T}_{\mathrm{CO}_{2}, \mathrm{t}}$ e a produtividade em biomassa, $\mathrm{P}_{\mathrm{bt}}$, foram calculados para um período $\mathrm{t}$ de incubação através da Equação 8 e da Equação 9, respectivamente.

$$
\begin{gathered}
F_{\mathrm{CO}_{2}}=\left(X(t)-X_{0}\right) \frac{M_{\mathrm{CO}_{2}}}{M_{c}} \\
P_{b t}=\frac{\left(X(t)-X_{0}\right)}{t} \\
T_{\mathrm{CO}_{2}, t}=\frac{\left(X(t)-X_{0}\right)}{t} \frac{M_{\mathrm{CO}_{2}}}{M_{c}}=\frac{F_{C O_{2}}}{t}
\end{gathered}
$$

\subsubsection{Consumo de íons tiossulfato e nitrato}


Além das taxas de fixação de carbono, ensaios em batelada e a $20 \% \mathrm{CO}_{2}$ avaliaram a capacidade das cepas selecionadas de oxidar tiossulfato (fonte de energia) a sulfato e utilizar nitrato como aceptor de elétrons. Cultivos controle foram estabelecidos em meios de cultura que não continham nitrato ou tiossulfato. $\mathrm{O}$ consumo bacteriano do nitrato e a eventual redução deste íon a $\mathrm{NO}_{2}{ }^{-}$foram verificados através de kits colorimétricos comerciais (Prodac, Prodactest $\mathrm{NO}_{3}$ 0-50 mg/L e Prodactest $\mathrm{NO}_{2}$ 0-3 mg/L). As concentrações de tiossulfato e de sulfato no meio de cultura foram determinadas através de cromatografia iônica (IC) (Metrohm, Professional IC 850), conforme descrito em Kwon et al (2015).

\subsubsection{Análise estatística dos dados}

A análise estatística dos dados foi realizada através do software GraphPad Prism 8.0.1. Quando houve homogeneidade na variância dos grupos de dados, a técnica $\operatorname{ANOVA}(\alpha=0,05)$, seguida do teste Turkey para comparações múltiplas, foi utilizada para comparar os parâmetros cinéticos obtidos a partir de ensaios distintos. Para comparações entre grupos de dados com variâncias heterogêneas, os testes de Welch e Brown-Forsythe foram empregados em conjunto com o teste de comparações múltiplas Games-Howell $(\alpha=0,05)$. Os diferentes modelos de crescimento bacteriano foram comparados através do Critério de Informação de Akaike Corrigido $\left(\mathrm{AIC}_{\mathrm{c}}\right)$ (WAGENMAKERS, FARRELL, 2004). 


\section{RESULTADOS E DISCUSSÕES}

\subsection{ENRIQUECIMENTO E ISOLAMENTO DE BACTÉRIAS ACLIMATADAS A CO}

Águas marinhas e sedimentos marinhos antárticos são conhecidos por abrigar uma grande diversidade de bactérias autotróficas (fototróficas e quimioautotróficas) capazes de fixar $\mathrm{CO}_{2}$ (HÜGLER, SIEVERT, 2011; WILKINS et al., 2012). Assim, com o intuito de avaliar uma tecnologia sustentável para mitigar as emissões industriais de $\mathrm{CO}_{2}$, este trabalho isolou bactérias quimioautotróficas de sedimentos marinhos antárticos e estudou o comportamento destas sob diferentes condições de cultivo ( $\mathrm{T}$ e p $\mathrm{CO} 2$ ).

$\mathrm{Na}$ primeira etapa do projeto, correspondente ao enriquecimento de bactérias aclimatadas a elevadas concentrações de $\mathrm{CO}_{2}$, quatro cultivos em batelada foram inoculados com sedimentos antárticos e mantidos no escuro sob atmosfera de ar e $\mathrm{CO}_{2}$ (30\%, $\left.1 \mathrm{~atm}\right)$. Após 30 dias de incubação, os quatro cultivos apresentaram turbidez, indicando um possível crescimento bacteriano. Este crescimento foi confirmado mediante disseminação das culturas em meio sólido, obtendo-se 30 colônias bacterianas.

A concentração celular final de cada cultivo de enriquecimento variou conforme o meio de cultura utilizado. Para os cultivos nos meios AM e ASM, a concentração de bactérias viáveis foi igual ou superior a 1.000.000 CFU/ml. Por sua vez, as culturas estabelecidas nos meios SM e MM apresentaram menores concentrações celulares. Uma concentração mínima de 300.000 $\mathrm{CFU} / \mathrm{ml}$ foi atingida no meio SM, enquanto a cultura MM, suplementada apenas com manitol (fonte orgânica de carbono e energia), apresentou a menor quantidade de células bacterianas dentre os quatro meios avaliados $(300 \mathrm{CFU} / \mathrm{ml})$. Estes resultados sugerem que o maior número de células viáveis nos cultivos $\mathrm{AM}$ e $\mathrm{ASM}$ se deve à presença de $\left(\mathrm{NH}_{4}\right)_{2} \mathrm{SO}_{4}$ nos mesmos. $\mathrm{O}$ $\left(\mathrm{NH}_{4}\right)_{2} \mathrm{SO}_{4}$ ou $\mathrm{NH}_{4}{ }^{+}$, além de possível doador de elétrons, é fonte extra de nitrogênio, um nutriente fundamental para o crescimento bacteriano (GOTTSCHAK, 1979). Ainda, o crescimento de bactérias nas culturas SM e MM, ambas deficientes em N, P e vitaminas, pode indicar que as cepas obtidas a partir destes meios são adaptadas a ambientes com restrição de nutrientes.

A comparação morfológica das 30 colônias isoladas (Figura 17), seguida da identificação via espectrometria de massas (MALDI-TOF), resultou em 15 cepas bacterianas 
distintas. Os perfis proteicos gerados para cada uma das colônias não apresentaram correspondência significativa com as espécies contidas no banco de dados Biotyper (Bruker Daltonics). Entretanto, com o auxílio dos softwares mMass e das análises de PCA/clusters, os espectros foram avaliados conforme descrito na seção de materiais e métodos.

Figura 17 - Cepas com morfologias distintas, espalhadas em placas de BHI.

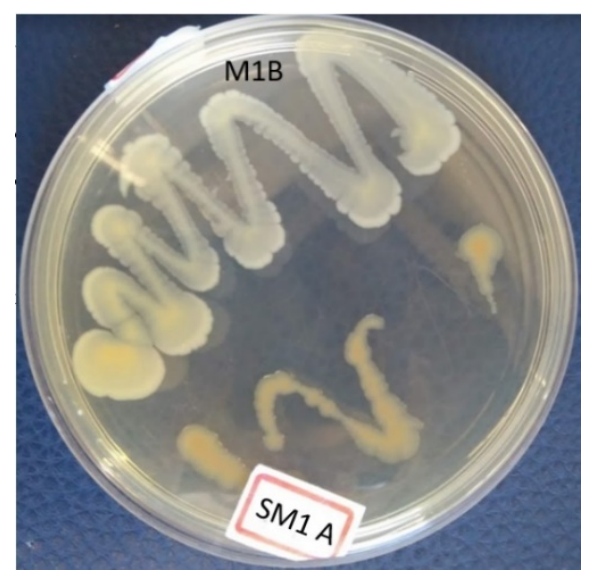

A Figura 18 apresenta a justaposição dos diferentes espectros de massa e perfis eletroforéticos gerados in silico para as 11 colônias isoladas do meio AM. A correspondência entre as intensidades e posições dos picos, assim como das bandas eletroforéticas, foram utilizadas como critério para estabelecer as diferenças entre as cepas (KERSTERS et al, 1994). Desta forma, três cepas do meio AM (AM2A, AM2B e AM2C) foram consideradas distintas, já que apresentaram espectros de massa diferentes (Figura18c, APÊNDICE B). As demais cepas provenientes deste meio exibiram perfis iguais ou semelhantes à AM2A (Figura18a), ou à AM2B (Figura18b).

Ainda, o cultivo no meio ASM recuperou o maior número de espécies do sedimento antártico. Neste meio, 5 cepas foram consideradas diferentes segundo seus espectros de massa. De modo semelhante, 4 cepas foram isoladas a partir do cultivo no meio de cultura SM. No entanto, assim como para o meio AM, o cultivo de enriquecimento no meio $\mathrm{MM}$ resultou em apenas 3 cepas distintas. O APÊNDICE B apresenta os espectros de massa e perfis de eletroforese utilizados para estabelecer as semelhanças entre as bactérias isoladas. A Tabela 8 contém as cepas isoladas e a concentração celular determinada após 30 dias de incubação nos meios de cultura AM, ASM, SM e MM. 
Figura 18 - Espectros de massa e perfis eletroforéticos das proteínas extraídas das bactérias do meio AM. a) as cepas AM1B, AM1C, AM2A, AM3A, AM4A E AM4B apresentam perfis eletroforéticos semelhantes, e foram consideradas de espécies similares. b) as cepas AM1A, AM3B, AM1D e AM2B foram agrupadas em uma mesma espécie ou em espécies semelhantes. c) as cepas $\mathrm{AM} 2 \mathrm{~A}, \mathrm{AM} 2 \mathrm{~B}$ e $\mathrm{AM} 2 \mathrm{C}$ foram consideradas distintas.
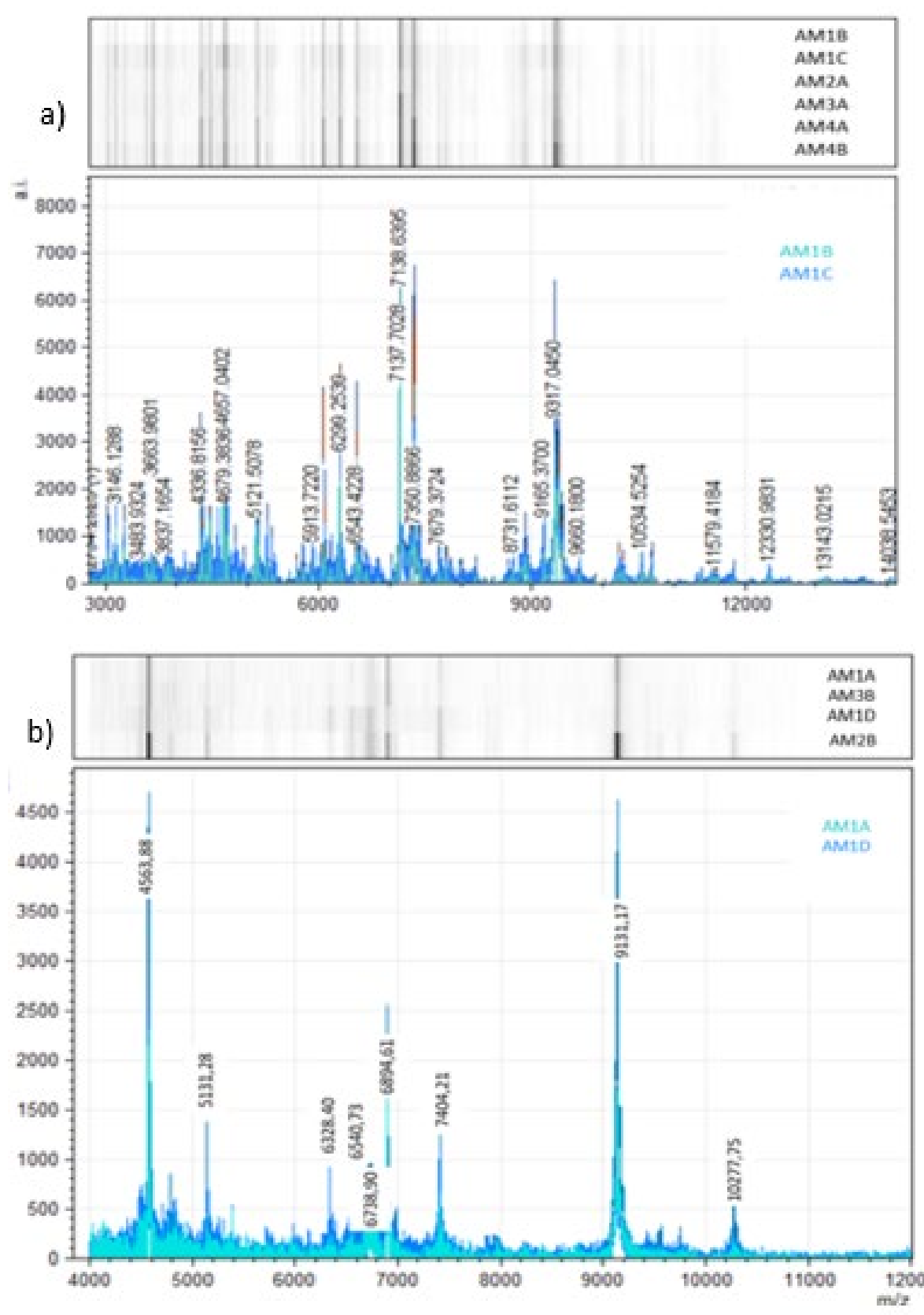

c)

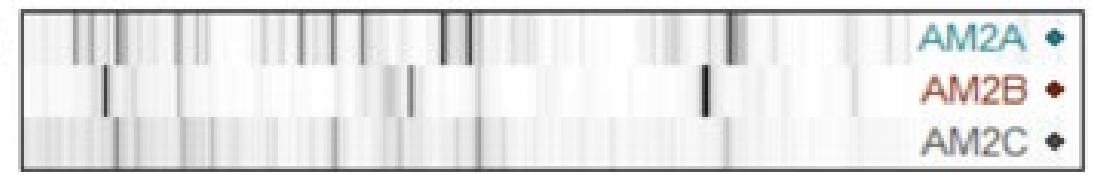


Tabela 8 - Resultados do isolamento bacteriano realizado a partir de sedimento marinho antártico. $\mathrm{O}$ sedimento foi incubado em diferentes meios de cultura e sob atmosfera de $30 \% \mathrm{CO}_{2}$.

\begin{tabular}{cclll}
\hline $\begin{array}{c}\text { Meio de } \\
\text { enriquecimento }\end{array}$ & $\begin{array}{c}\text { No } \text { cepas } \\
\text { isoladas }\end{array}$ & \multicolumn{1}{c}{ Cepas } & $\begin{array}{c}\text { Concentração } \\
\text { celular } \\
\text { (CFU/ml) }\end{array}$ & Fonte de elétrons \\
\hline MM & 3 & M1A, M1B e M1C & $\approx 300$ & Manitol \\
$\mathrm{SM}$ & 4 & SM1A, SM1B, SM1C e SM2A & $\geq 300.000$ & Manitol e $\mathrm{Na}_{2} \mathrm{~S}_{3} \mathrm{O}_{4}$ \\
$\mathrm{AM}$ & 3 & $\begin{array}{l}\text { AM2A, AM2C e AM2B } \\
\text { AS3A, AS3B, AS3C, AS3D, }\end{array}$ & $\geq 1.000 .000$ & $\begin{array}{l}\text { Manitol e }\left(\mathrm{NH}_{4}\right)_{2} \mathrm{SO}_{4} \\
\text { ASM }\end{array}$ \\
\hline
\end{tabular}

As 15 cepas descritas na Tabela 8 foram capazes de sobreviver na ausência de uma fonte de energia luminosa, em meio líquido salino $(2 \% \mathrm{NaCl})$ e sob atmosfera com elevada concentração de $\mathrm{CO}_{2}\left(30 \% \mathrm{CO}_{2}, \mathrm{p}_{\mathrm{CO} 2}=0,3 \mathrm{~atm}\right)$. Diferentemente de alguns microrganismos fotoautotróficos utilizados para biofixar carbono inorgânico, as cepas aqui obtidas crescem na ausência de energia luminosa e não apresentam inibição de crescimento em pressões parciais de $\mathrm{CO}_{2}$ superiores a 0,05 atm (BAE et al., 2001; ANAND, RAGHUVANSHI, GUPTA, 2020). Desta forma, as bactérias isoladas no presente estudo podem ser potencialmente utilizadas no tratamento de gases de exaustão e de gás natural, além de representarem uma alternativa mais energeticamente econômica para a biomitigação de $\mathrm{CO}_{2}$.

\subsection{SELEÇÃO DE BACTÉRIAS QUIMIOAUTOTRÓFICAS}

As bactérias isoladas e identificadas por espectrometria de massa foram posteriormente cultivadas sob condições quimioautotróficas, a $20 \% \mathrm{CO}_{2}$ e com o fornecimento de $\mathrm{P}$ e $\mathrm{N}$. Paralelamente, para cada cepa, quatro cultivos controle foram estabelecidos em meios suplementados com carbono orgânico (manitol ou acetato). Metade dos controles foi mantida sob atmosfera ambiente, e a outra metade atmosfera com $20 \% \mathrm{CO}_{2}$.

Todos os cultivos controle exibiram crescimento após 7 dias de incubação sob $20 \% \mathrm{CO}_{2}$ e sob atmosfera ambiente ( $1 \mathrm{~atm}, 0,04 \% \mathrm{CO}_{2}$ ). Tanto os meios suplementados com manitol, quanto os meios suplementados com acetato, apresentaram turbidez, de modo a sugerir um aumento na densidade celular das culturas. $\mathrm{O}$ crescimento observado na presença de carbono orgânico, no escuro e sem suplemento de $\mathrm{CO}_{2}$ sugere que as 15 cepas isoladas são capazes de 
exibir um metabolismo heterotrófico, consumindo manitol e acetato como fontes de carbono e energia. Ademais, o crescimento sob $20 \% \mathrm{CO}_{2}$ e com o aporte de substratos orgânicos pode indicar, além do comportamento heterotrófico, a possibilidade de mixotropia (consumo de carbono orgânico e inorgânico) (KELLY, 1981).

Considerando os cultivos realizados sob condições de quimioautotrofia, apenas 7 das 15 colônias avaliadas foram capazes de crescer no intervalo de 7 dias e alcançar uma concentração celular maior que $\mathrm{DO}=0,4$. As demais cepas exibiram crescimento relativamente lento, atingindo densidades celulares superiores a 0,4 somente após 9-21 dias de incubação. Dentre as 7 colônias que exibiram maior crescimento em um ambiente contendo $20 \%$ de $\mathrm{CO} 2$, duas foram obtidas quando incubadas em meio suplementado com $\mathrm{NH}_{4}{ }^{+}$(meio $\mathrm{A}$ ), duas em meio suplementado com $\mathrm{S}_{2} \mathrm{O}_{3}{ }^{-2}$ (meio $\mathrm{S}$ ) e três em meio suplementado com $\mathrm{NH}_{4}{ }^{+}$e $_{2} \mathrm{O}_{3}{ }^{-2}$ (meio AS). As 7 cepas quimioautotróficas resultantes do processo de seleção são descritas na Tabela 9.

Tabela 9 -Cepas quimioautotróficas selecionadas após 7 dias de cultivo no escuro, em meio mineral e sob $20 \% \mathrm{CO}_{2}$.

\begin{tabular}{cccc}
\hline $\begin{array}{c}\text { Cepas } \\
\text { quimioautotróficas }\end{array}$ & Meio de seleção & $\begin{array}{c}\text { Meio de enriquecimento } \\
\text { inicial }\end{array}$ & Substrato orgânico consumido \\
\hline M1B-S e M1A-S & S & MM & Manitol $(5 \mathrm{~g} / \mathrm{L})$ e acetato $(5 \mathrm{~g} / \mathrm{L})$ \\
AM2A e AM2B & A & AM & Manitol $(5 \mathrm{~g} / \mathrm{L})$ e acetato $(5 \mathrm{~g} / \mathrm{L})$ \\
AS3A, AS3B e AS3C & AS & ASM & Manitol $(5 \mathrm{~g} / \mathrm{L})$ e acetato $(5 \mathrm{~g} / \mathrm{L})$ \\
\hline
\end{tabular}

\subsection{CULTIVO DE BACTÉRIAS QUIMIOAUTOTRÓFICAS EM BATELADA}

As 7 cepas quimioautotróficas selecionadas (M1B-S, M1A-S, AM2A, AM2B, AS3A, AS3B e AS3C) foram transferidas para frascos fechados $(50 \mathrm{ml})$ e cultivadas sob as mesmas condições adotadas na etapa de seleção $\left(20 \% \mathrm{CO}_{2}, 30^{\circ} \mathrm{C}\right.$, escuro). $\mathrm{O}$ crescimento das culturas foi acompanhado ao longo de 10-14 dias e as curvas de crescimento resultantes são apresentadas na Figura 19 e na Figura 20. A velocidade máxima de crescimento $\left(\mu_{\text {máx }}\right)$, a densidade celular máxima $\left(\mathrm{DO}_{\text {máx }}\right)$ e os tempo de duplicação $\left(\mathrm{t}_{\mathrm{d}}\right)$ de cada uma das culturas são descritos na Erro!

\section{Fonte de referência não encontrada..}

De modo geral, as cepas quimioautotróficas isoladas neste trabalho caracterizaram-se por velocidades máximas de crescimento similares às bactérias quimioautotróficas e aos microrganismos fotoautotróficas utilizados para estudar a biofixação de $\mathrm{CO}_{2}$ (BAE et al., 2001) 
(Tabela 10). Estas cepas também foram capazes de crescer em um ambiente com elevada concentração de $\mathrm{CO}_{2}(20 \%)$ e sem aporte de vitaminas ou de energia luminosa.

Tabela 10 - Parâmetros cinéticos de crescimento e características das cepas quimioautotróficas cultivadas sob $20 \% \mathrm{CO}_{2}$ e em diferentes meios de cultura minerais. As concentrações de nitrogênio ([N]) em cada meio eram distintas.

\begin{tabular}{cccccccc}
\hline Cepas & $\begin{array}{c}\boldsymbol{\mu}_{\text {máx }}{ }^{*} \\
\left(\mathbf{d}^{-1}\right)\end{array}$ & $\begin{array}{c}\mathbf{t}_{\mathbf{d}} \\
(\mathbf{d})\end{array}$ & $\begin{array}{c}\text { Meio de } \\
\text { cultura }\end{array}$ & $\begin{array}{c}\mathbf{[ N ]} \\
(\mathbf{m m o l} / \mathbf{L})\end{array}$ & $\begin{array}{c}\text { DOmáx } \\
(\mathbf{6 0 0 n m})\end{array}$ & $\begin{array}{c}\text { Cultura } \\
\text { isolada }\end{array}$ & $\begin{array}{c}\text { Contaminação } \\
\text { por fungos }\end{array}$ \\
\hline M1A-S & 0,884 & 0,784 & $\mathrm{~S}$ & 21,2 & 1,87 & Não & Sim \\
AS3A & 0,469 & 1,48 & AS & 75,8 & 2,54 & Sim & Sim \\
AS3C & 0,367 & 1,89 & AS & 75,8 & 0,877 & Não & Não \\
AM2B & 0,332 & 2,09 & A & 75,8 & 0,482 & Sim & Sim \\
M1B-S & 0,325 & 2,13 & S & 21,2 & 1,25 & Sim & Não \\
AS3B & 0,159 & 4,36 & AS & 75,8 & 0,838 & Não & Não \\
AM2A & 0,109 & 6,34 & A & 75,8 & 0,470 & Sim & Sim \\
\hline
\end{tabular}

*Média entre as velocidades máximas de crescimento calculadas através da regressão linear da fase de crescimento exponencial e do modelo Logístico Modificado descrito em Corradini e Peleg (2005).

Os dados de crescimento registrados para as diferentes cepas mostraram que, dentre todas as culturas avaliadas, a AM2A e a AM2B resultaram nas menores concentrações celulares, sendo caracterizadas por DOs finais iguais a 0,44 e 0,50 , respectivamente. A fase de crescimento exponencial destas culturas ocorreu entre os primeiros quatro dias de incubação e apresentou velocidades máximas de crescimento iguais a $0,109 \mathrm{~d}^{-1}$, para a cepa AM2A, e 0,332 $\mathrm{d}^{-1}$, para a cepa AM2B (Tabela 10). Adicionalmente, as curvas de crescimento obtidas para AM2A e AM2B não exibiram fase lag detectável e atingiram densidades celulares máximas (DO máx) no $9^{\circ}$ dia de cultivo (Figura 19a e Figura 19b). Após este dia, ambas as culturas entraram em fase de crescimento estacionário e subsequente redução nas concentrações celulares $(\mathrm{p}<0,05)($ DORAN, 1995). Os cultivos AM2A e AM2B mantiveram-se axênicos durante 13 dias de incubação, conforme resultado de análise em meio sólido. Entretanto, no $14^{\circ}$ dia de cultura, já no estado estacionário do crescimento, foi possível observar a proliferação de fungos no meio líquido de ambos os cultivos. Este fato pode indicar que, mediante a depleção de nutrientes e/ou cessação do crescimento, as cepas AM2B e AM2A tornam-se suscetíveis à contaminação por outros microrganismos. Com isso, considerou-se que a eventual aplicação destas cepas em processos industriais de captura de $\mathrm{CO}_{2}$ poderia ser inviabilizada.

As culturas AS3C e AS3B, por sua vez, apresentaram densidades celulares máximas superiores às registradas para os cultivos AM2A e AM2B, atingindo $\mathrm{DO}_{\text {máx }}$ igual a 0,877 e 0,838, respectivamente (Figura19c e Figura 19d). A cepa AS3C permaneceu em fase lag durante 2 dias e exibiu máxima velocidade de crescimento entre o $2^{\circ}$ e o $3^{\circ}$ dia de cultivo $\left(\mu_{\operatorname{máx}}=\right.$ $\left.0,367 \mathrm{~d}^{-1}\right)$. A cultura de AS3B, diferentemente de AS3C, não exibiu fase lag e foi caracterizada 
por uma menor velocidade máxima de crescimento, equivalente a $0,159 \mathrm{~d}^{-1}$. No entanto, o cultivo de AS3C e AS3B em meio sólido indicou que estes isolados não se encontravam puros, e continham, respectivamente, duas e três cepas bacterianas distintas. A identificação destas cepas via espectrometria de massas MALDI-TOF não foi realizada, já que, em todos os ensaios realizados, as colônias obtidas em meio sólido encontravam-se adjacentes ou sobrepostas umas às outras e, assim, não puderam ser fisicamente separadas.

Figura 19 - Curvas de crescimento das colônias quimioautotróficas selecionadas. a) cepa AMA, b) cepa AM2B, b) cepa AS3B, d) cepa AS3C, e) cepa M1A-S e f) cepa M1B-S. Os cultivos foram mantidos no escuro, em meios minerais, a $30^{\circ} \mathrm{C}$ e sob atmosfera de ar e $\mathrm{CO}_{2}(20 \% \mathrm{v} / \mathrm{v})$.

a)

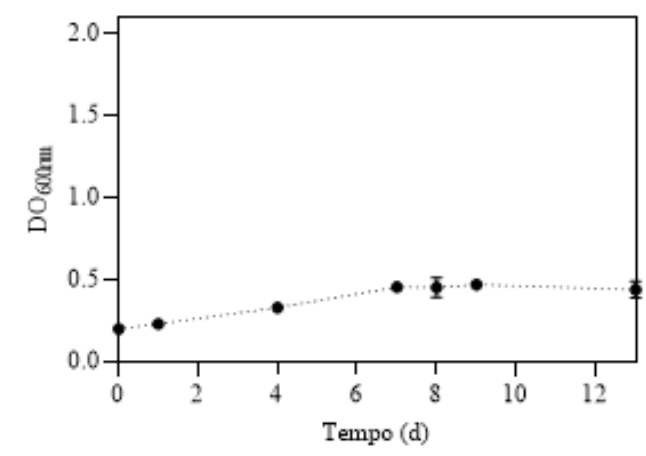

c)

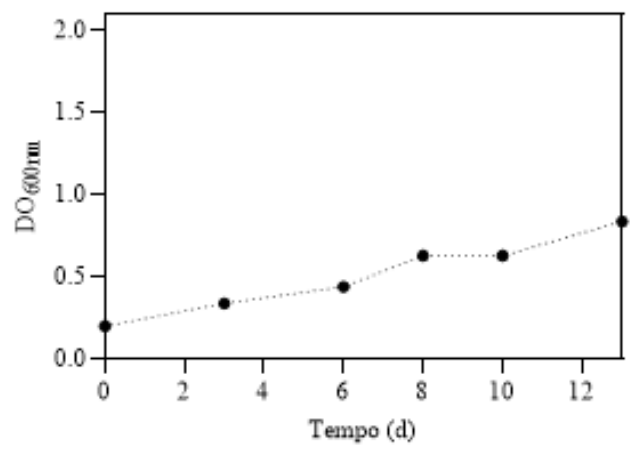

e)

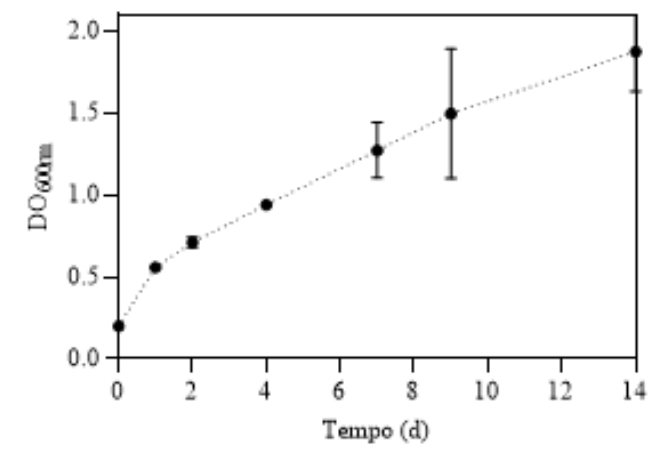

b)

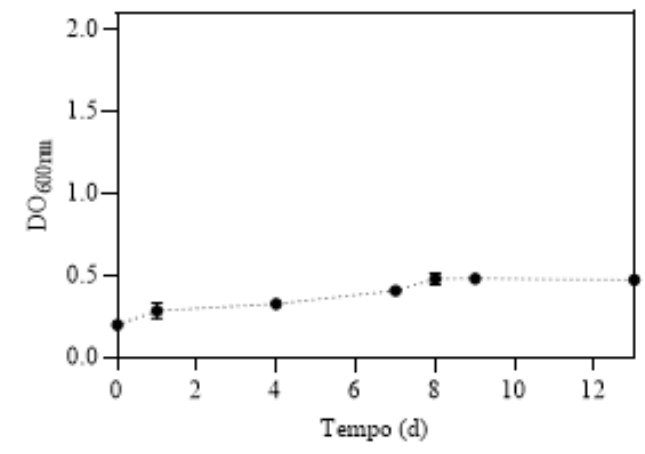

d)

$\mathrm{AS} 3 \mathrm{C}$

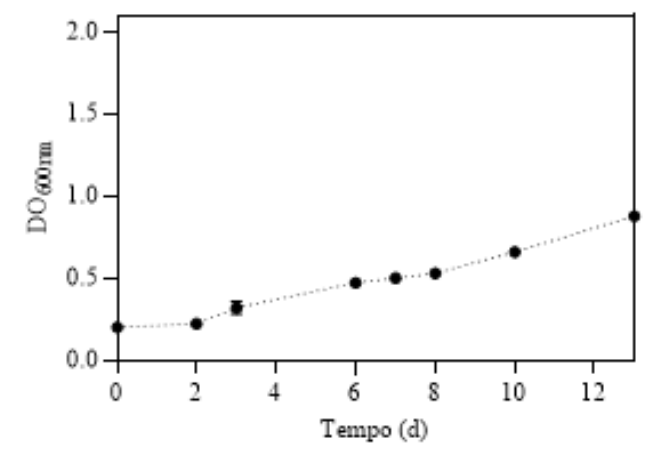

f)

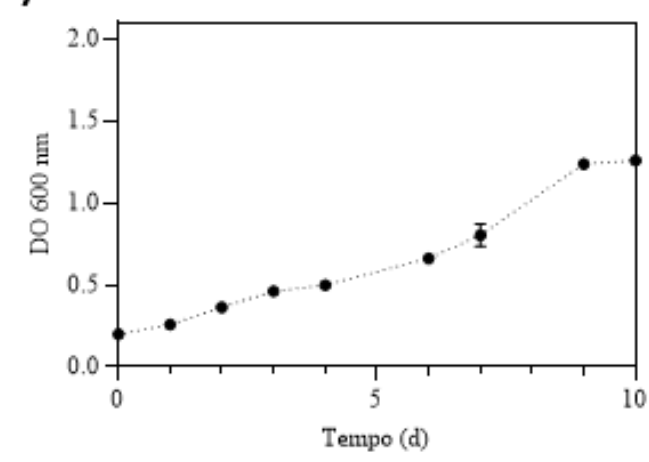

Além disso, a presença de diferentes cepas bacterianas em AS3C e AS3B pode explicar o comportamento exibido pelas curvas de crescimento destes cultivos. Após atingir uma 
concentração celular estável durante dois dias, os cultivos voltaram a apresentar crescimento até o $15^{\circ}$ dia de incubação e não foram afetados por contaminações externas (fungos). Este comportamento diauxico de AS3C e AS3B pode, também, indicar possível consumo tanto de $\mathrm{S}_{2} \mathrm{O}_{3}{ }^{-}$, quanto $\mathrm{NH}_{4}{ }^{+}$como substratos energéticos (VAN DEDEM, YOUNG, 1975).

Assim como AS3B e AS3C, a cultura M1A-S não aparentava estar pura, sendo constituída por duas cepas morfologicamente distintas. Estas bactérias foram isoladas em meio sólido e identificadas via MALDI-TOF MS, resultando em espectros visualmente similares (APÊNDICE B). Segundo análise realizada no software mMass, alguns picos $(<30 \%)$ exibiram intensidades e posições distintas, de modo que as cepas encontradas podem corresponder à mesma espécie ou a espécies semelhantes. Ademais, a cultura M1A-S exibiu a maior velocidade máxima de crescimento dentre os 7 cultivos mantidos sob $20 \% \mathrm{CO}_{2}\left(0,884 \mathrm{~d}^{-1}\right)$ e atingiu $\mathrm{DO}_{\text {máx }}$ de 1,87 (Tabela 10). Não obstante, após 15 dias de incubação a cultura foi contaminada por fungos. A fim de avaliar a suscetibilidade a contaminações, replicatas do cultivo M1A-S foram realizadas e, novamente, exibiram crescimento de fungos após 12-17 dias de incubação.

A maior densidade celular foi observada para o cultivo AS3A. Após 6 dias incubação, esta cultura caracterizou-se por uma $\mathrm{DO}_{\text {máx }}$ de 2,54, a qual manteve-se aproximadamente constante durante 6-9 dias (fase de crescimento estacionário). A bactéria AS3A exibiu, ainda, a segunda maior velocidade máxima de crescimento $\left(0,469 \mathrm{~d}^{-1}\right)$, estabelecida entre o $1^{\circ}$ e o $6^{\circ}$ dia de cultivo (Figura 20). Ao longo de 12-15 dias de incubação, a cultura AS3A permaneceu pura e formou biofilme microbiano no meio líquido e nas paredes dos frascos de cultura. Apesar do promissor comportamento quimioautotrófico da cepa AS3A, cultivos realizados em triplicata mostraram que esta bactéria se torna sensível a contaminações por fungos quando incubada em bateladas de duração média superior a 11 dias.

Figura 20 -Crescimento da cepa AS3A sob atmosfera de ar e $\mathrm{CO}_{2}(20 \%)$.

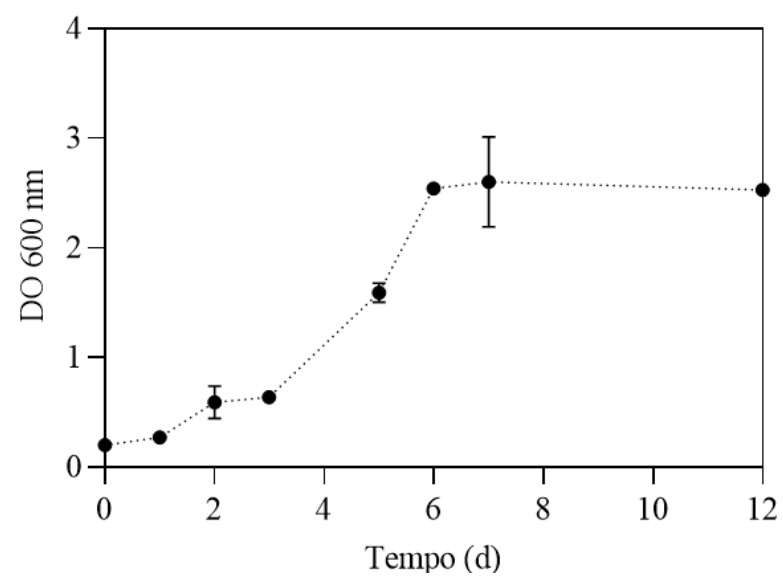


Apenas uma cultura quimioautotrófica, dentre as 7 avaliadas, apresentou um conjunto de características que podem viabilizar a sua aplicação em processos industriais de captura de $\mathrm{CO}_{2}$. As cepas ou cultivos que demonstraram baixas densidades celulares $\left(\mathrm{DO}_{\text {máx }}<0,4\right)$, crescimento lento $\left(\mu_{\text {máx }}<0,2 \mathrm{~d}^{-1}\right)$, possível impureza e/ou suscetibilidade a contaminações foram consideradas pouco vantajosas em relação a microalgas e aos demais microrganismos atualmente estudados para biofixação de carbono. Neste contexto, somente a cepa M1B-S caracterizou-se por combinar crescimento rápido $\left(\mu_{\text {máx }}>0,2 \mathrm{~d}^{-1}\right)$, altos valores de $\mathrm{DO}_{\text {máx }}$ $\left(\mathrm{DO}_{\text {máx }}>0,4\right)$, pureza e aparente resistência a contaminações por fungos (Figura 19f). O crescimento máximo da cepa foi observado após uma fase lag inicial e exibiu $\mu_{\text {máx }}$ de $0,325 \mathrm{~d}^{-}$ ${ }^{1}$ (Tabela 10). Ainda, o cultivo M1B-S atingiu DO máx de 1,25 em 10 dias de incubação e assim manteve-se por mais 7 dias. Após este período, foi possível identificar a formação de biofilme no fundo e nas laterais do frasco de cultura.

Ademais, a observação visual das culturas de M1B-S permitiu identificar a produção de bolhas de gás em todo o volume do meio de cultura. Em média, estas bolhas formavam-se a partir do início do crescimento exponencial ( $1^{\circ}$ ou $2^{\circ}$ dia de incubação) e até a cultura atingir densidade constante $\left(8^{\circ}\right.$ ou $9^{\circ}$ dia). Logo, sugere-se que estes gases sejam produtos do metabolismo e do crescimento da cepa M1B-S. Ainda, a análise da concentração de íons no meio de cultura de M1B-S, realizada durante a fase exponencial de crescimento da bactéria, evidencia o consumo de $\mathrm{NO}_{3}{ }^{-}$e a produção de sua forma reduzida, o $\mathrm{NO}_{2}{ }^{-}$(APÊNDICE E). De modo concomitante, o pH do meio de cultura tornou-se alcalino em comparação ao início do cultivo. Estas evidencias podem indicar que a bactéria M1B-S é desnitrificante, capaz de utilizar $\mathrm{NO}_{3}{ }^{-}$como aceptor de elétrons e reduzi-lo a $\mathrm{NO}_{2}{ }^{-}$(MIYAHARA et al., 2010). As análises de concentração de substratos mostraram, também, que $\mathrm{NO}_{3}^{-}$e $\mathrm{NO}_{2}{ }^{-}$foram completamente consumidos após 10 dias de incubação. Desta forma, é possível que a cepa M1B-S promova a redução completa de $\mathrm{NO}_{3}{ }^{-}$e $\mathrm{NO}_{2}{ }^{-}$a gás nitrogênio $\left(\mathrm{N}_{2}\right)$ ou a óxido nitroso $\left(\mathrm{N}_{2} \mathrm{O}\right)$, fato condizente com a formação de bolhas gasosas no meio de cultivo (FERGUSON, 1994).

O consumo e redução de $\mathrm{NO}_{3}{ }^{-}$, juntamente com o crescimento quimiautotrófico sob $20 \%$ $\mathrm{CO}_{2}$, possibilita a eventual aplicação da bactéria M1B-S tanto no tratamento de efluentes líquidos, quanto na remoção simultânea de $\mathrm{CO}_{2}$ e $\mathrm{NO}_{\mathrm{x}}$ de gases de combustão industriais (ZHENG et al., 2016). Desta forma, visando o seu emprego em processos industriais, a cepa M1B-S foi identificada e o seu comportamento quimiautotrófico foi investigado sob diferentes condições de cultivo. 


\subsection{IDENTIFICAÇÃO DA CEPA SELECIONADA VIA SEQUENCIAMENTO DE 16s rDNA}

Os resultados do sequenciamento de $16 \mathrm{~S}$ rDNA indicaram 100\% de similaridade entre a cepa M1B-S e o gênero Alcanivorax sp. (APÊNDICE F) e uma identidade de 99,8\% com as espécies Alcanivorax xenomutans (NR_133958.1) e Alcanivorax dieselolei (NR_074734.1 e NR_043106.1). A Tabela 11 apresenta as similaridades entre as sequências parciais do fragmento 16S rDNA da cepa M1B-S e dos organismos referenciados no banco de dados GenBank. O dendograma filogenético da cepa M1B-S encontra-se representado na Figura 21.

Tabela 11 - Similaridades da sequência de 16S rDNA parcial entre a cepa M1B-S e bactérias de referência.

\begin{tabular}{cc}
\hline Organismo & Identidade (\%) \\
\hline Alcanivorax xenomutans & 99,80 \\
Alcanivorax dieselolei & 99,80 \\
Alcanivorax balearicus & 99,06 \\
Alcanivorax nanhaiticus & 95,64 \\
Alcanivorax gelatiniphagus & 95,12 \\
Alcanivorax marinus & 95,11 \\
Alcanivorax venustensis & 95,10 \\
\hline
\end{tabular}

O gênero Alcanivorax sp. (classe Gammaproteobacteria) é composto por bactérias marinhas hidrocarbonoclásticas capazes de degradar compostos derivados de petróleo, incluindo n-alcanos, alcanos ramificados, alcenos, hidrocarbonetos aromáticos e hidrocarbonetos policíclicos aromáticos (HPAs) (BRZESZCZ, KASZYCKI, 2018; SILVEIRA, THOMPSON, 2014). Os diversos representantes deste gênero habitam ecossistemas marinhos, sendo particularmente abundantes em áreas de derramamento de óleo e em reservatórios/poços de petróleo e gás (XIAO et al., 2016). Consequentemente, as diferentes espécies de Alcanivorax são adaptadas a ambientes extremos e oligotróficos, onde, além da deficiência de nutrientes (e.g. N, P, elementos traço), substâncias tóxicas como $\mathrm{H}_{2} \mathrm{~S}, \mathrm{SO}_{\mathrm{x}}, \mathrm{NO}_{\mathrm{x}}$ e mercaptanos (tioálcoois) estão presentes (MARRIOT et al., 2015; YAKIMOV, CAPELLO, 2010). Assim, é possível sugerir que a cepa M1B-S será capaz de resistir e crescer em um ambiente contendo gás natural bruto ou gases de exaustão de origem industrial. 
Figura 21 - Dendograma filogenético gerado com a ferramenta BLAST e baseado na sequência parcial do gene 16S rRNA (16S rDNA) da cepa M1B-S. A análise considerou uma máxima diferença de sequências igual a 0,3 .

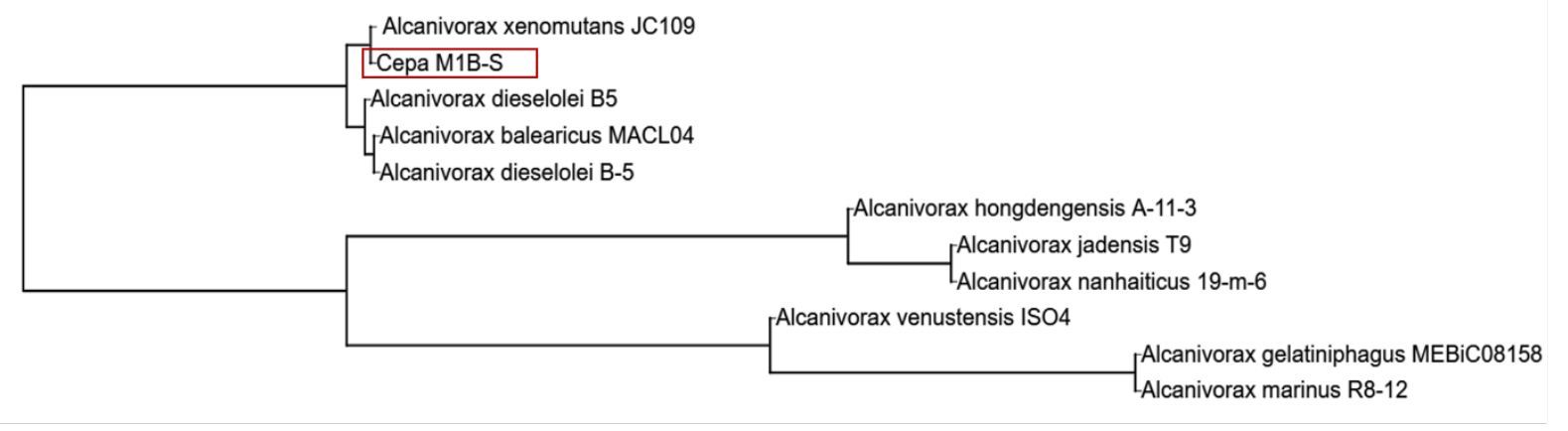

Tree scale: 0.01

Em comparação com as demais espécies do gênero Alcanivorax, os resultados preliminares deste estudo sugerem que M1B-S cresce em temperatura, pHs e salinidade semelhantes às reportadas como ideais para as demais bactérias do grupo. Enquanto M1B-S exibiu crescimento a $30^{\circ} \mathrm{C}, 2,6 \% \mathrm{~m} / \mathrm{v}$ de $\mathrm{NaCl}$ e $\mathrm{pH}$ de $5,6-8,7$, as cepas de Alcanivorax atualmente conhecidas crescem em temperaturas de $4^{\circ} \mathrm{C}-45^{\circ} \mathrm{C}$ (ótimo entre $28^{\circ} \mathrm{C}-40^{\circ} \mathrm{C}$, mesófilas), em concentrações salinas de $0,5 \%$ - $20 \% \mathrm{~m} / \mathrm{v} \mathrm{NaCl}$ (ótimo entre 1,5\%-10\% m/v, halófilas), em pHs de 4-11 (ótimo entre 6-8) e resistem a elevadas pressões (>100 bar) (RAHUL et al., 2014; BRUNS, BERTHE-CORTI, 1999; SCOMA et al., 2016) Não obstante, ensaios adicionais são necessários para avaliar as condições ótimas e extremas (mínima e máxima) para o crescimento de M1B-S.

Adicionalmente, a provável capacidade de M1B-S utilizar íons $\mathrm{NO}_{3}{ }^{-}$como aceptor terminal de elétrons também é observada em outras cepas de Alcanivorax. Apresar de ser um grupo composto por bactérias predominantemente aeróbias, espécies como a A. xenomutans e A. jadensis são anaeróbias facultativas e reduzem $\mathrm{NO}_{3}{ }^{-}$a $\mathrm{NO}_{2}{ }^{-}$e a $\mathrm{N}_{2}$ (RAHUL et al., 2014; BERTHE-CORTI, 1999; OKPALA et al., 2017; MULLA et al., 2018).

Quanto à obtenção de energia e carbono, até o presente, a bactéria M1B-S é a única cepa de Alcanivorax a demonstrar crescimento quimioautotrófico. As espécies deste gênero são reportadas como organoheterotróficas obrigatórias, consumindo principalmente hidrocarbonetos e alguns ácidos orgânicos (SILVEIRA, THOMPSON, 2014; RAHUL et al., 2014; YAKIMOV et al., 1998). No entanto, assim como para M1B-S, o uso de tiossulfato como fonte energética também foi reportado para outras cepas identificadas como Alcanivorax (KEEG, 2020). 
Além das características já citadas, os membros do gênero Alcanivorax são reconhecidos por apresentar crescimento em biofilme e por produzir lipídeos, PHA (polyhydroxyalcanoates), EPS (substâncias poliméricas extracelulares) e biossurfactantes (MANILLA-PÉREZ et al., 2011; SILVEIRA, THOMPSON, 2014; JADJELOVIC et al., 2020). De modo semelhante às espécies do mesmo gênero, os resultados apresentados na seção anterior mostram que M1B-S também possui a capacidade de forma biofilme. Esta característica possibilita, por exemplo, o emprego desta cepa em sistemas de captura de carbono constituídos por equipamentos como biofiltros, reatores de leito móvel com biofilme (MBBR), biorreatores de membrana (MBR) e biorreatores de leito gotejante (TBR) (SHARMA et al., 2016). Ademais, sugere-se que estudos futuros avaliem a produção de lipídios, EPS, bio-óleo e biodiesel originados a partir da fixação de $\mathrm{CO}_{2}$ realizada por M1B-S.

\subsection{CARACTERIZAÇÃO DA CEPA QUIMIOAUTOTRÓFICA SELECIONADA}

O crescimento da cepa M1B-S e a sua capacidade de fixar carbono inorgânico foram avaliadas sob pressões parciais de $\mathrm{CO}_{2}$ e temperaturas semelhantes às encontradas em gases de exaustão e gás natural. Todos estes ensaios de caracterização foram desenvolvidos com fornecimento restrito de alguns nutrientes e empregando o $\mathrm{CO}_{2}$ como a única fonte de carbono.

\subsubsection{Crescimento sob diferentes concentrações de $\mathrm{CO}_{2}$}

Os parâmetros cinéticos de crescimento e de fixação de $\mathrm{CO}_{2}$ da cepa M1B-S foram determinados sob atmosferas contendo ar e $0 \%, 5 \%, 10 \%$ e $20 \% \mathrm{v} / \mathrm{v}$ de $\mathrm{CO}_{2}\left(30^{\circ} \mathrm{C}, \mathrm{P}=1 \mathrm{~atm}\right)$. Os resultados obtidos estão descritos na Tabela 12 e na Tabela 13.

A cultura realizada na ausência de $\mathrm{CO}_{2}\left(\begin{array}{lll}0 \% & \left.\mathrm{CO}_{2}\right) & \text { não apresentou crescimento }\end{array}\right.$ significativo $(\mathrm{p}<0,5, \mathrm{n}=3)$ (Figura 22), de modo que a sua densidade celular se manteve aproximadamente constante ao longo de 10 dias de cultivo. No entanto, a bactéria M1B-S foi capaz de crescer quando cultivada sob concentrações de $\mathrm{CO}_{2}$ acima de $5 \% \mathrm{v} / \mathrm{v}\left(\mathrm{p}_{\mathrm{CO} 2}\right.$ de 0,05 atm, $0,1 \mathrm{~atm}$ e $0,2 \mathrm{~atm})$. 
A cepa M1B-S exibiu o maior crescimento a maior fixação de carbono a 5\% e $10 \% \mathrm{CO}_{2}$ (Figura 22 e Figura 23). A cultura mantida sob $\mathrm{p}_{\mathrm{CO} 2}=0,05$ atm $\left(5 \% \mathrm{CO}_{2}\right)$ apresentou máxima concentração em biomassa e máxima fixação de carbono após 7 dias de incubação $\left(\mathrm{X}_{\text {máx }}=1,85\right.$ $\mathrm{g} / \mathrm{L}$ e $\left.\mathrm{F}_{\mathrm{CO} 2 \text {,máx }}=1,35 \mathrm{~g} / \mathrm{L}\right)$, enquanto o cultivo sob $\mathrm{p}_{\mathrm{CO} 2}=0,1$ atm $\left(10 \% \mathrm{CO}_{2}\right)$ atingiu o máximo crescimento e fixação de carbono entre o $7^{\circ}$ e o $9^{\circ}$ dia de incubação $\left(\mathrm{X}_{\text {máx }}=1,82 \mathrm{~g} / \mathrm{L}\right.$ e $\mathrm{F}_{\mathrm{CO} 2 \text {,máx }}=$ $1,29 \mathrm{~g} / \mathrm{L}$ ). Os valores de $\mathrm{X}_{\text {máx }}$ e $\mathrm{F}_{\mathrm{CO} 2}$, máx atingidos a $5 \%$ e $10 \% \mathrm{CO}_{2}$ não apresentara diferença significativa entre $\mathrm{si}(\mathrm{p}>0,05, \mathrm{p}=0,3399$ e $\mathrm{p}=0,281$, respectivamente). O menor crescimento da cepa M1B-S foi observado a 20\% $\mathrm{CO}_{2}\left(\mathrm{p}_{\mathrm{co} 2}=0,2 \mathrm{~atm}\right)(\mathrm{p}<0,05)$ (Figura 22 e Figura 24). Nestas condições de incubação, obteve-se uma biomassa máxima de 1,67 g/L e uma máxima fixação de $\mathrm{C}_{\mathrm{i}}$ de $1,02 \mathrm{~g} / \mathrm{L}$ (Tabela 13). Em relação aos cultivos mantidos a 5 e $10 \% \mathrm{CO}_{2}$, a cultura desenvolvida a $20 \% \mathrm{CO}_{2}$ apresentou uma redução de $21 \%$ na capacidade de capturar $\mathrm{CO}_{2}$.

Não obstante, os resultados relatados acima sugerem que, mesmo quando submetidas a concentrações relativamente elevadas de gás carbônico (>10\%,1 atm) e a condições de restrição nutricional, as culturas de M1B-S podem atingir altas concentrações celulares e fixar apreciáveis quantidades de $\mathrm{CO}_{2}$. Tal comportamento, ideal para o emprego de microrganismos no tratamento de gases de exaustão industriais (3-25\% $\left.\mathrm{CO}_{2}\right)$, não é exibido por muitas espécies de microalgas e de bactérias autotróficas avaliadas para a captura de carbono (WATANABE, OHMURA, SAIKI, 1992; MOGHIMIFAM et al., 2019). Liu et al. (2019), por exemplo, reportam cultivos em batelada da microalga C. protothecoides nos quais o aumento da concentração de $\mathrm{CO}_{2}$ de $10 \%$ para $20 \%$ provoca uma redução média de $50 \%$ na biomassa final obtida (de 1,08 g/L para 0,55 g/L).

Figura 22 - Curvas de crescimento da cepa M1B-S quando cultivada sob diferentes concentrações de $\mathrm{CO}_{2}$. a) curva de crescimento em DO e b) curva de crescimento em biomassa (X, g/L).
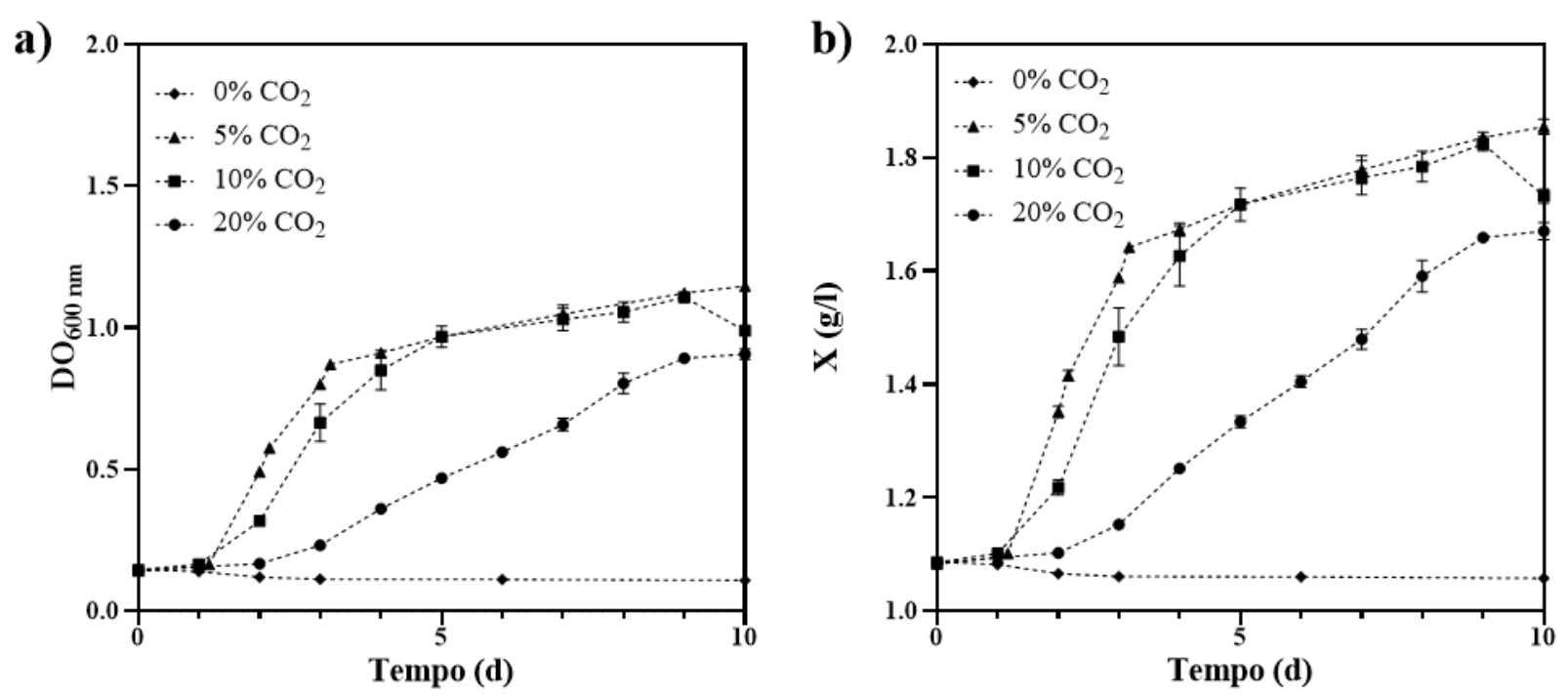
Figura 23 - Comparação da quantidade de $\mathrm{CO}_{2}$ fixada pela cepa M1B-S quando cultivada em bateladas submetidas a atmosferas com diferentes concentrações de $\mathrm{CO}_{2}\left(1 \mathrm{~atm}, 30^{\circ} \mathrm{C}\right)$.

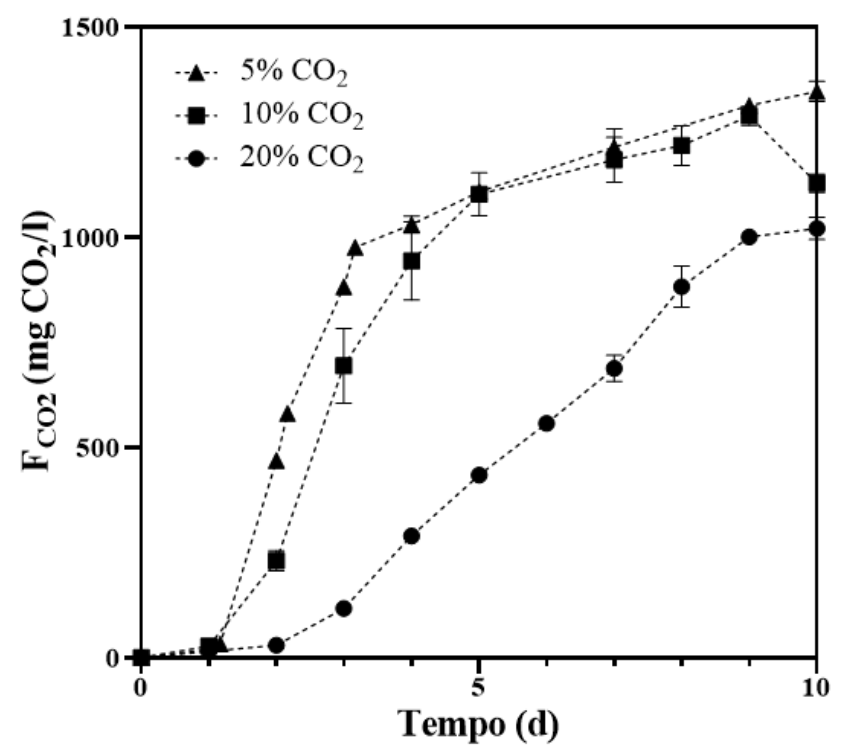

Figura 24 - Comparação do crescimento e fixação de carbono entre as culturas da cepa M1B$\mathrm{S}$ sob diferentes concentrações de $\mathrm{CO}_{2}$ a) máximo rendimento em biomassa $\left(\mathrm{X}_{\text {máx }}\right)$ e b) máxima fixação de carbono inorgânico ( $\left.\mathrm{F}_{\mathrm{CO} 2 \text {,máx }}\right)$.

a)

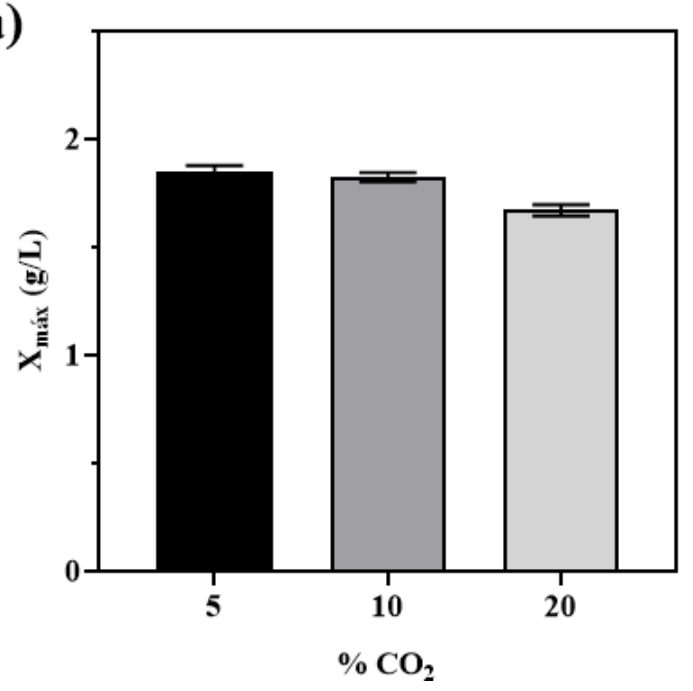

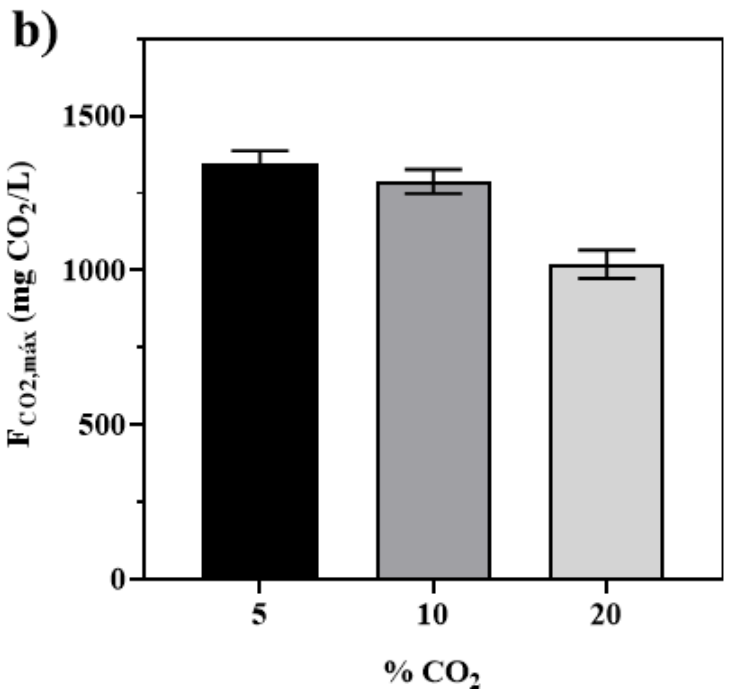

Ademais, além de demonstrar capacidades relativamente elevadas de fixar $\mathrm{CO}_{2}$ e uma vez alcançado o $\mathrm{X}_{\text {máx }}$, todos os ensaios realizados com a cepa M1B-S mantiveram suas concentrações celulares constantes ( $p<0,05)$, não exibindo fases de declínio celular no intervalo de tempo avaliado (10 dias). Consequentemente, cultivos em batelada visando a máxima produção de biomassa e máxima fixação de carbono poderiam ser realizados com durações de

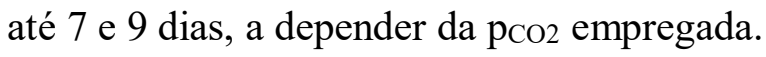


Em adição aos parâmetros já discutidos, o impacto de p $_{\mathrm{CO} 2}$ na velocidade de crescimento de M1B-S também foi investigado em ambientes contendo $5 \%, 10 \%$ e $20 \% \mathrm{v} / \mathrm{v}$ de $\mathrm{CO}_{2}$ (1 atm). Nestes ensaios, diferentes modelos matemáticos de crescimento bacteriano foram empregados

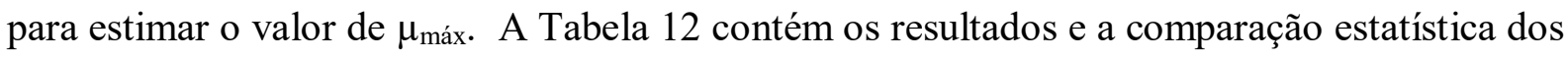
diferentes modelos utilizados.

Tabela 12 -Parâmetro $\mu_{\text {máx }}$ (intervalo de confiança assimétrico de 95\%) obtido em diferentes concentrações de $\mathrm{CO}_{2}$ e computado através dos modelos de crescimento Logístico Modificado, Gompertz Modificado, Linear e tipo Potência Modificado. A qualidade dos ajustes foi determinada através da comparação entre $\mathrm{o} \mathrm{AIC}_{\mathrm{C}}$ de cada modelo. Os valores mais prováveis de $\mu_{\text {máx }}$ encontram-se em negrito.

\begin{tabular}{|c|c|c|c|c|c|}
\hline $\begin{array}{l}\text { Concentração } \\
\text { de } \mathrm{CO}_{2}\left(\mathrm{pco}_{2}\right)\end{array}$ & $\begin{array}{l}\text { Modelo de } \\
\text { crescimento }\end{array}$ & $\begin{array}{c}\mu_{\operatorname{máx}} \\
(95 \% \text { IC) } \\
\left(d^{-1}\right) \\
\end{array}$ & $\mathrm{AIC}_{\mathrm{c}}$ & $\Delta \mathrm{AIC}_{\mathrm{c}}$ & $\begin{array}{c}\text { Probabilidade } \\
\text { de estar } \\
\text { correto }\end{array}$ \\
\hline \multirow{4}{*}{$\begin{array}{c}5 \% \mathrm{v} / \mathrm{v} \\
(0,05 \mathrm{~atm})\end{array}$} & Logístico Modificado & $\begin{array}{c}1,386 \\
(1,167-1,715)\end{array}$ & $-163,5$ & 17,66 & $0,02 \%$ \\
\hline & Gompertz Modificado & $\begin{array}{c}1,294 \\
(1,170-1,445)\end{array}$ & $-181,1$ & 0 & $99,98 \%$ \\
\hline & $\begin{array}{c}\text { Linear } \\
\text { (fase exponencial) }^{*}\end{array}$ & $\begin{array}{c}1,27 \\
(1,19-1,34)\end{array}$ & $-48,24$ & 135,26 & $\sim 0 \%$ \\
\hline & Tipo Potência ${ }^{* *}$ & $\begin{array}{c}1,254 \\
(0,6318-1,876) \\
\end{array}$ & $-76,50$ & 106,9 & $\sim 0 \%$ \\
\hline \multirow{4}{*}{$\begin{array}{l}10 \% \mathrm{v} / \mathrm{v} \\
(0,1 \mathrm{~atm})\end{array}$} & Logístico Modificado & $\begin{array}{c}0,7911 \\
(0,6621-0,96)\end{array}$ & $-134,7$ & 1,7 & $20,4 \%$ \\
\hline & Gompertz Modificado & $\begin{array}{c}0,8189 \\
(0,7026-0,9866)\end{array}$ & $-135,6$ & 0,8 & $32,0 \%$ \\
\hline & $\begin{array}{c}\text { Linear } \\
\text { (fase exponencial) }^{*}\end{array}$ & $\begin{array}{c}0,6905 \\
(0,5806-0,8004)\end{array}$ & $-30,58$ & 105,82 & $\sim 0 \%$ \\
\hline & Tipo Potência** & $\begin{array}{c}0,5354 \\
(0,474-0,6215)\end{array}$ & $-136,4$ & 0 & $47,7 \%$ \\
\hline \multirow{4}{*}{$\begin{array}{l}20 \% \mathrm{v} / \mathrm{v} \\
(0,2 \mathrm{~atm})\end{array}$} & Logístico Modificado & $\begin{array}{c}0,3311 \\
(0,2954-0,3726)\end{array}$ & $-148,8$ & 12,2 & $0,22 \%$ \\
\hline & Gompertz Modificado & $\begin{array}{c}0,3528 \\
(0,3208-0,3881)\end{array}$ & $-161,0$ & 0 & $99,78 \%$ \\
\hline & $\begin{array}{c}\text { Linear } \\
\text { (fase exponencial) }^{*}\end{array}$ & $\begin{array}{c}0,3863 \\
(0,3497-0,4229)\end{array}$ & $-50,34$ & 110,7 & $\sim 0 \%$ \\
\hline & Tipo Potência ${ }^{* *}$ & $\begin{array}{c}0,2843 \\
(0,2017-0,3669)\end{array}$ & $-110,4$ & 50,6 & $\sim 0 \%$ \\
\hline
\end{tabular}

*Regressão linear dos dados da fase exponencial de crescimento.

${ }^{* *} \mathrm{O}$ modelo de crescimento Tipo Potência necessitou tempos de computação superiores aos demais modelos.

Para os cultivos de M1B-S submetidos a atmosferas com $5 \% \mathrm{CO}_{2}$ e $20 \%$ de $\mathrm{CO}_{2}(1$ atm), a análise estatística indicou que o modelo de crescimento Gompertz Modificado fornece o melhor ajuste para os dados experimentais. Já para a curva de crescimento a $10 \% \mathrm{CO}_{2}(1$ atm), os modelos Gompertz Modificado e tipo Potência Modificado apresentaram qualidade semelhante nos ajustes, com $\Delta \mathrm{AIC}_{\mathrm{c}}$ inferior a 1 . Entretanto, como a regressão do modelo tipo 
Potência Modificado demandou um maior número de iterações, o valor de $\mu_{\text {máx }}$ a $10 \% \mathrm{CO}_{2}$ foi determinado a partir da equação de Gompertz Modificado. O ajuste completo das curvas de crescimento encontra-se no APÊNDICE $\mathrm{C}$ e as velocidades de crescimento para cada concentração de $\mathrm{CO}_{2}$ estão resumidas na Tabela 13.

Tabela 13 - Velocidades máximas de crescimento $\left(\mu_{\text {máx }}\right)$, máxima biomassa $\left(\mathrm{X}_{\text {máx }}\right)$, quantidade máxima de $\mathrm{CO}_{2}$ fixado $\left(\mathrm{F}_{\mathrm{CO} 2 \text {,máx }}\right)$, máxima produtividade de biomassa $\left(\mathrm{P}_{\mathrm{b} \text {,máx }}\right)$ e máxima taxa de fixação de $\mathrm{CO}_{2}\left(\mathrm{~T}_{\mathrm{CO} 2 \text {,máx }}\right.$ obtidas nos cultivos de M1B-S sob diferentes concentrações de $\mathrm{CO}_{2}$ (médias $\pm \mathrm{SD}$ ).

\begin{tabular}{cccccc}
\hline$\% \mathbf{C O}_{2}$ & $\boldsymbol{\mu}_{\text {máx }}\left(\mathbf{d}^{-1}\right)$ & $\mathbf{X}_{\text {máx }}(\mathbf{g} / \mathbf{L})$ & $\mathbf{F C O 2 , ~ m a ́ x ~}_{\mathbf{m g} / \mathbf{L})}$ & $\mathbf{P}_{\text {b,máx }}(\mathbf{m g} / \mathbf{L} / \mathbf{d})$ & $\begin{array}{c}\mathbf{T C O}_{\mathbf{c} \text {,máx }} \\
(\mathbf{m g ~ C O} / \mathbf{L} / \mathbf{d})\end{array}$ \\
\hline 5 & $1,29 \pm 0,32$ & $1,85 \pm 0,024$ & $1346,0 \pm 41,2$ & $176,6 \pm 3,544$ & $308,0 \pm 6,18$ \\
10 & $0,81 \pm 0,34$ & $1,82 \pm 0,022$ & $1288 \pm 38,7$ & $135,2 \pm 23,16$ & $236,0 \pm 30,4$ \\
20 & $0,353 \pm 0,086$ & $1,67 \pm 0,025$ & $1021 \pm 45,8$ & $63,72 \pm 0,79$ & $111,0 \pm 1,38$ \\
\hline
\end{tabular}

Apesar dos cultivos desenvolvidos a 5\%,10\% e 20\% $\mathrm{CO}_{2}$ indicarem que as quantidades máximas de biomassa e de carbono fixado não variam de maneira apreciável com o aumento no teor de gás carbônico, os dados coletados mostram que concentrações de $\mathrm{CO}_{2}$ superiores a $5 \%\left(\mathrm{p}_{\mathrm{CO} 2}>0,5 \mathrm{~atm}\right)$ reduzem as velocidades máximas de crescimento da cepa M1B-S (Tabela 13). Consequentemente, as produtividades máximas em biomassa $\left(\mathrm{P}_{\mathrm{b} \text {,máx }}\right)$ e as taxas máximas de fixação de $\mathrm{CO}_{2}\left(\mathrm{~T}_{\mathrm{CO} 2 \text {,máx }}\right)$ também são afetadas por pressões parciais de $\mathrm{CO}_{2}$ acima de 0,05 $\operatorname{atm}(\mathrm{p}<0,05)$ (Figura 25).

Segundo estudos, embora altas $\mathrm{p}_{\mathrm{CO} 2}\left(\% \mathrm{CO}_{2}\right)$ possam acarretar maior disponibilidade de DIC no meio de cultura, também tendem a promover alterações no $\mathrm{pH}$ dos cultivos e no metabolismo de bactérias, microalgas e cianobactérias (BAE et al., 2001; POURJAMSHIDIAN et al., 2019; JIN et al., 2020; ESPARZA et al., 2019). Por exemplo, quando cultivada sob atmosfera de $20 \% \mathrm{v} / \mathrm{v} \mathrm{CO}_{2}$ (1 atm), a bactéria Acidithiobacillus ferrooxidans sofre alterações metabólicas e cresce a uma taxa 2 vezes menor que a observada em cultivos sob $5 \% \mathrm{v} / \mathrm{v} \mathrm{CO}_{2}$ (1 atm) (ESPARZA et al., 2019). Similarmente, a maioria das espécies de microalgas e cianobactérias geralmente têm seu crescimento restrito a cultivos com pressões parciais de $\mathrm{CO}_{2}$ inferiores a 0,05 atm (ANAND, RAGHUVANSHI, GUPTA, 2020). Portanto, assim como observado em outros microrganismos, sugere-se que o metabolismo da cepa M1B-S possa ser inibido sob elevadas concentrações de $\mathrm{CO}_{2}$. 
Figura 25 -a) produtividade em biomassa $\left(\mathrm{P}_{\mathrm{b}}\right)$ e b) taxa de fixação de $\mathrm{CO}_{2}\left(\mathrm{~T}_{\mathrm{CO} 2}\right)$ da cepa M1B$\mathrm{S}$ quando cultivada em batelada e sob diferentes concentrações de $\mathrm{CO}_{2}\left(5 \%, 10 \%\right.$ e $20 \% \mathrm{CO}_{2} \mathrm{v} / \mathrm{v}, 1 \mathrm{~atm}$, $\left.30^{\circ} \mathrm{C}\right)$.

a)

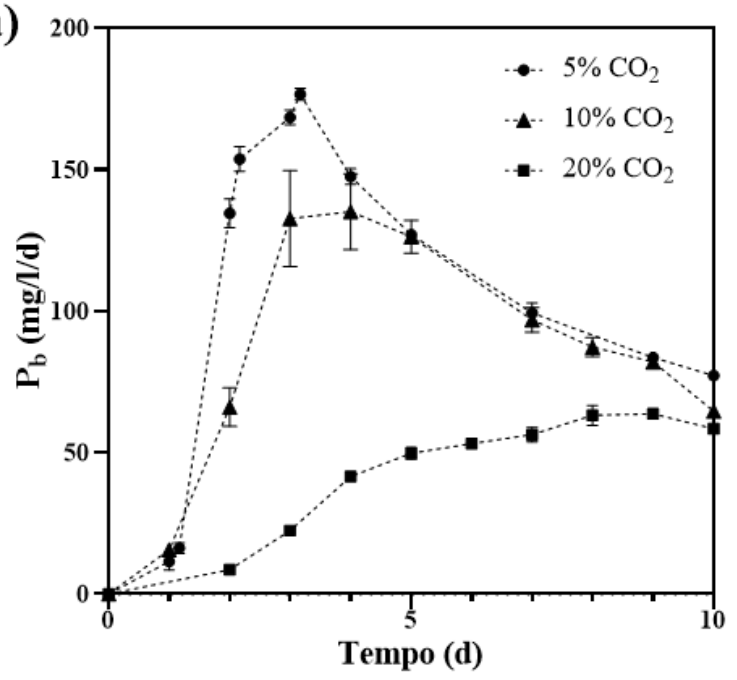

b)

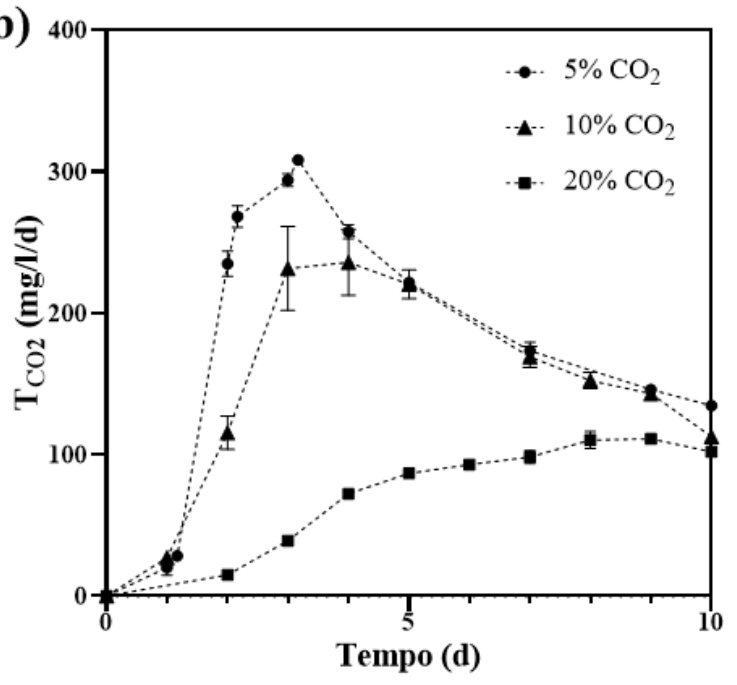

De acordo com o exposto na Tabela 13, a maior velocidade máxima de crescimento, a maior produtividade em biomassa e a maior taxa de fixação de $\mathrm{CO}_{2}$ resultaram da incubação de M1B-S a $5 \% \mathrm{CO}_{2}(\mathrm{p}<0,05)$. Após uma fase lag de aproximadamente 1 dia, as culturas apresentaram crescimento exponencial entre $24-54 \mathrm{~h}$, sendo caracterizadas por $\mu_{\text {máx }}$ de $1,29 \pm$ $0,32 \mathrm{~d}^{-1}$ e por um tempo de duplicação $\left(\mathrm{t}_{\mathrm{d}}\right)$ de $0,54 \pm 0,14 \mathrm{~d}$. Ainda sob estas condições, os valores máximos de $\mathrm{P}_{\mathrm{b}}(176,7 \mathrm{mg} / \mathrm{L} / \mathrm{d})$ e de $\mathrm{T}_{\mathrm{CO} 2}(308 \mathrm{mg} / \mathrm{L} / \mathrm{d})$ foram observados após $76 \mathrm{~h}$ de cultivo (Tabela 13 e Figura 25).

Em comparação ao cultivo mantido sob $5 \% \mathrm{CO}_{2}$, as culturas realizadas a $10 \% \mathrm{CO}_{2}$ exibiram produtividades máximas de biomassa e taxas máximas de fixação de carbono $23 \pm 14 \%$ inferiores $\left(\mathrm{P}_{\mathrm{b} \text {,máx }}=135,2 \mathrm{mg} / \mathrm{L} / \mathrm{d}\right.$ e $\mathrm{T}_{\mathrm{CO} 2}$, máx $\left.=236 \mathrm{mg} / \mathrm{L} / \mathrm{d}\right)(\mathrm{p}<0,0001)$. Estes resultados foram observados entre 72 h e 96 h de incubação (Figura 25). Já os valores de $\mu_{\text {máx }}$ e de $t_{d}$ a $10 \% \mathrm{CO}_{2}$ foram de $0,81 \pm 0,34 \mathrm{~d}^{-1}$ e $0,86 \pm 0,43 \mathrm{~d}$, respectivamente, sendo obtidos entre os dias 1 e 3 de cultivo. Ademais, sob estas mesmas condições, as culturas em batelada de M1B-S também apresentaram fase lag com duração de 1 dia.

A menor velocidade de crescimento máximo da cepa M1B-S foi observada a $20 \% \mathrm{CO}_{2}$ e correspondeu a menos de $1 / 3$ do valor obtido nos ensaios a $5 \% \mathrm{CO}_{2}\left(\mu_{\operatorname{máx}}=0,353 \pm 0,086 \mathrm{~d}^{-1}\right.$ e $\mathrm{t}_{\mathrm{d}}=1,96 \pm 0,5 \mathrm{~d}$ ). A curva de crescimento de M1B-S a $\mathrm{p}_{\mathrm{CO}_{2}}=0,2$ atm exibiu, ainda, uma fase lag de maior duração (2 dias) e uma subsequente fase de crescimento exponencial até o $4^{\circ}$ dia de 
cultivo. O maior tempo de adaptação a $20 \% \mathrm{CO}_{2}$, juntamente com a menor $\mu_{\text {máx }}$, culminaram em reduções na produtividade máxima e na taxa máxima de fixação de carbono de M1B-S

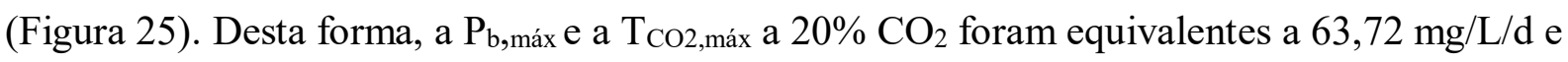
$111,0 \mathrm{mg} / \mathrm{L} / \mathrm{d}$, respectivamente, e foram atingidas após 9 dias de incubação (Figura 25 e Figura 26).

Figura 26 - a) produtividade máxima em biomassa $\left(\mathrm{P}_{\mathrm{b} \text {,máx }}\right)$ e b) taxa máxima de fixação de $\mathrm{CO}_{2}$ $\left(\mathrm{T}_{\mathrm{CO} 2 \text {, máx }}\right)$ da cepa M1B-S quando cultivada em batelada e sob diferentes concentrações de $\mathrm{CO}_{2}(1 \mathrm{~atm}$, $\left.30^{\circ} \mathrm{C}\right)$.

a)

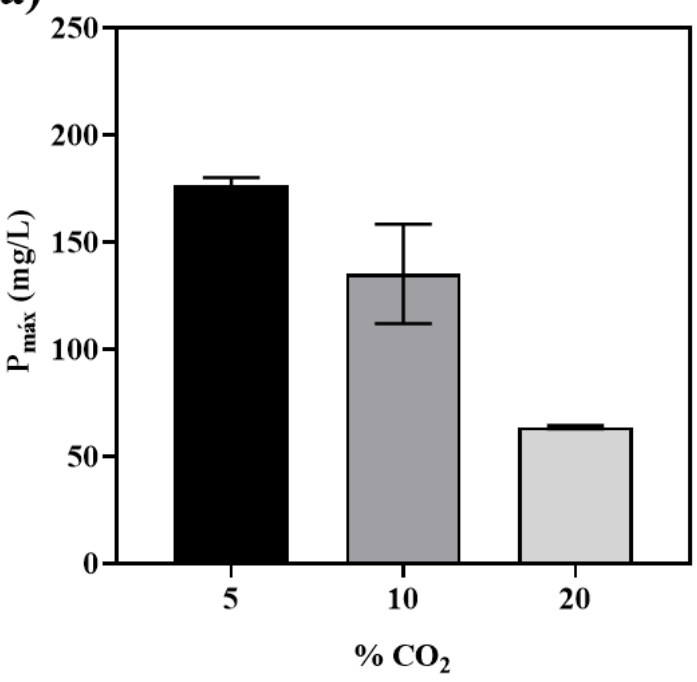

b)

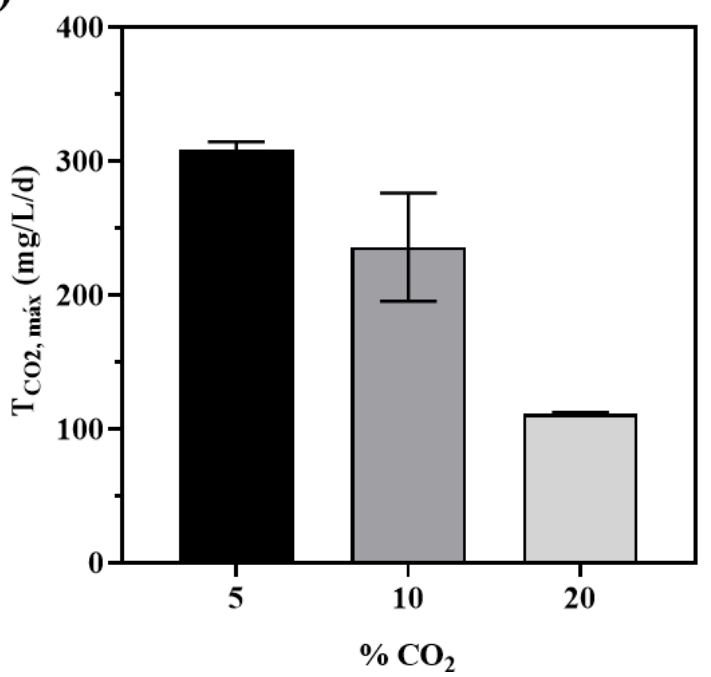

Embora os resultados obtidos demonstrem que pressões parciais de $\mathrm{CO}_{2}$ acima de 0,05 atm $(\mathrm{P}=1 \mathrm{~atm})$ podem retardar o crescimento da cepa M1B-S e reduzir as suas produtividades e taxas de fixação de $\mathrm{CO}_{2}$, os parâmetros do crescimento quimioautotrófico de M1B-S, obtidos a $5 \%, 10 \%$ e $20 \% \mathrm{CO}_{2}$ (1 atm), são, de modo geral, equiparáveis aos encontrados em muitos cultivos de microalgas e bactérias autotróficas (MOGHIMIFAM et al., 2019; BAE et al., 2001; DE MORAIS, COSTA, 2007). A fim de ilustrar esta comparação, os próximos parágrafos irão relacionar o desempenho de M1B-S com o de outros microrganismos utilizados na captura de carbono.

a) comparação de M1B-S com microalgas e cianobactérias:

As velocidades específicas de crescimento de microalgas geralmente são reportadas na faixa de $0,018 \mathrm{~d}^{-1}$ e $2,1 \mathrm{~d}^{-1}$, enquanto as taxas de fixação de $\mathrm{CO}_{2}$ para estes microrganismos variam entre 19,2 e 45,6 mg CO $2 / \mathrm{L} / \mathrm{d}$ (KWON et al., 2015). O trabalho de Moreira et al. (2016), por exemplo, realizou culturas semicontínuas de Spirulina sp. e Chlorella fusca a $10 \% \mathrm{CO}_{2}$ e 
obteve valores de $\mu_{\text {máx }}$ que corresponderam, respectivamente, a $0,092 \mathrm{~d}^{-1}$ e $0,071 \mathrm{~d}^{-1}$ (vs. 0,81 $\mathrm{d}^{-1}$ de M1B-S).

Já Jin et al. (2020) caracterizaram a biofixação de carbono inorgânico em seis diferentes cepas de microalgas dos gêneros Chlorella, Heynigia, Desmodesmus e Scenedesmus, cultivadas a $28{ }^{\circ} \mathrm{C}$, $1 \mathrm{~atm}$ e em fotobiorreatores com capacidade de 2,5 L. Neste estudo, os pesquisadores avaliaram o crescimento das cepas sob $0,03 \%, 5 \%, 10 \%$ e $15 \% \mathrm{CO}_{2}$ e obtiveram velocidades máximas de crescimento entre $0,3 \mathrm{~d}^{-1}$ e $0,95 \mathrm{~d}^{-1}$. Especificamente, as velocidades de todas as microalgas incubadas sob $5 \%$ e $10 \% \mathrm{CO}_{2}$ foram inferiores aos valores de $\mu_{\text {máx }}$ resultantes dos cultivos de M1B-S sob estas mesmas $\mathrm{p}_{\mathrm{CO} 2}$. Adicionalmente, mesmo em volumes de cultura 50 vezes menores e a temperaturas maiores $\left(30^{\circ} \mathrm{C}\right)$, as produtividades máximas observadas para M1B-S a $5 \%$ e $10 \% \mathrm{CO}_{2}$ foram similares aos dados de $\mathrm{P}_{\mathrm{b} \text {,máx }}$ levantados para as cepas de microalgas C. sorokiniana XJ02, Chlorella sp. NM01, D. communis GS05 e S. obliquus NM02(JIN et al., 2020).

b) comparação de M1B-S com bactérias quimioautotróficas e heterotróficas geneticamente modificadas:

O crescimento quimioautotrófico de M1B-S mostrou-se, ainda, comparável ao de bactérias atualmente estudadas na biofixação de carbono inorgânico, e.g. bactérias oxidadoras de hidrogênio (HOB), de ferro ou de enxofre (SOB) e espécies heterotróficas geneticamente modificadas (SALEHIZADEH, YAN, FARNOOD, 2020; BAE et al., 2001; MISHRA et al., 2017b).

Os dados de $\mu_{\text {máx }}$ e $\mathrm{T}_{\mathrm{CO} 2 \text {,máx }}$ exibidos por M1B-S a $20 \% \mathrm{CO}_{2}, 1$ atm e $30^{\circ} \mathrm{C}$, por exemplo, são semelhantes aos reportados para a cepa Pseudomonas aeruginosa SSL-4 (MISHRA et al., 2017a). Em culturas de 8 dias sob $17 \% \mathrm{CO}_{2}\left(1 \mathrm{~atm}, 35^{\circ} \mathrm{C}\right)$ e utilizado Fe (II) como fonte de energia, esta bactéria cresceu a velocidades máximas de $0,34 \mathrm{~d}^{-1}$ (vs. 0,35 $\mathrm{d}^{-1}$ de M1B-S) e assimilou carbono com taxa máxima de $60 \mathrm{mg} / \mathrm{L} / \mathrm{d}$ (vs. 111,0 mg/L/d de M1B-S). Além disso, a quantidade de $\mathrm{CO}_{2}$ fixada por $P$. aeruginosa SSL-4 sob estas condições foi de

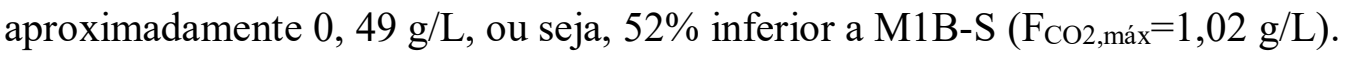

Não obstante, as características autotróficas de M1B-S também são análogas às exibidas por outras bactérias oxidadoras de enxofre (SOB), tais como a cepa $H$. stevensii SSL-5 (MISHRA et al., 2017b; PARK et al., 2020; HU et al., 2010; ESPARZA et al, 2019). Segundo Mishra et al. (2017b), quando cultivada em bateladas a $15 \% \mathrm{CO}_{2}\left(37^{\circ} \mathrm{C}, 1 \mathrm{~atm}\right)$ e com $7,9 \mathrm{~g} / \mathrm{L}$ 
ou 15,8 g/L de $\mathrm{N}_{2} \mathrm{~S}_{2} \mathrm{O}_{3}$ como fonte de elétrons, a bactéria $H$. stevensii SSL-5 foi caracterizada

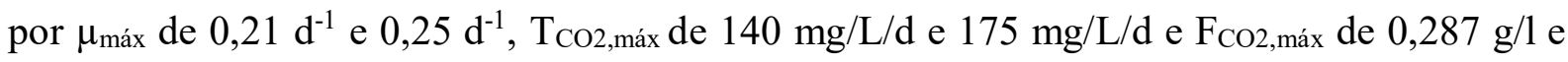
$0,347 \mathrm{~g} / \mathrm{L}$, respectivamente. Adicionalmente, em alguns estudos que empregam biorreatores contínuos e/ou suplementam o meio de cultura com vitaminas e maiores quantidades de nutrientes $\left(\mathrm{N}, \mathrm{P}\right.$, elementos traço, $\mathrm{S}_{2} \mathrm{O}_{3}{ }^{-2}$ ou $\mathrm{Na}_{2} \mathrm{~S}_{\text {e }} \mathrm{S}^{0}$ ), os valores de $\mu_{\text {máx }}$ e $\mathrm{T}_{\mathrm{CO} 2 \text {, máx associados }}$ às SOBs são superiores aos de M1B-S (PARK et al., 2020; KWON et al., 2015). Desta forma, sugere-se que o crescimento e capacidade de M1B-S fixar $\mathrm{CO}_{2}$ possam ser aprimorados através de cultivos contínuos e da otimização do meio de cultura.

Os dados presentes na literatura indicam, ainda, que o comportamento de M1B-S sob elevadas concentrações de $\mathrm{CO}_{2}$ é próximo ao de bactérias oxidadoras de hidrogênio (HOB). HOBs, incluindo espécies metanogênicas e acetogênicas, são o grupo de bactérias mais estudado para a captura de $\mathrm{CO}_{2}$, já que tendem a apresentar elevadas velocidades de crescimento e capacidades de fixar $\mathrm{C}_{\mathrm{i}}\left(\mu_{\text {máx }}>1,0 \mathrm{~d}^{-1}\right.$ e $\left.\mathrm{T}_{\mathrm{CO} 2}>200 \mathrm{mg} / \mathrm{L} / \mathrm{d}\right)$ (HU et al., 2010; SALEHIZADEH, YAN, FARNOOD, 2020; EMERSON et al., 2018; YU, LU, 2019). Como exemplo, em cultivos contínuos a $10 \% \mathrm{CO}_{2}\left(30^{\circ} \mathrm{C}, 2,5 \mathrm{~L}\right)$, a cepa $\mathrm{YN}-1$ isolada por Bae et al. (2001) exibiu uma velocidade máxima de $1,18 \mathrm{~d}^{-1}$, ou seja, um valor $45 \%$ maior que o encontrado para M1B-S sob iguais $\mathrm{p}_{\mathrm{CO} 2} \mathrm{e}$ T. Além disso, esta mesma cepa foi capaz de crescer em bateladas a $10 \% \mathrm{CO}_{2}$ e $40 \% \mathrm{CO}_{2}$ e com taxas tão altas quanto $0,34 \mathrm{~h}^{-1}\left(8,16 \mathrm{~d}^{-1}\right)(\mathrm{BAE}$ et al., 2001).

No entanto, a fixação de $\mathrm{CO}_{2}$ por $\mathrm{HOBs}$ frequentemente ocorre na presença de vitaminas e de carbono orgânico (acetato, succinato, extrato de levedura, etc.), fatores estes que podem encarecer o bioprocesso. Isto, juntamente com a necessidade de se fornecer $\mathrm{H}_{2}$ e com os riscos associados ao uso de grandes quantidades deste gás, fazem com que, apesar de menores $\mu_{\text {máx }} \mathrm{e}$ $\mathrm{T}_{\mathrm{CO} 2 \text {,máx, }}$ M1B-S possa ser considerada uma alternativa competitiva para captura biológica de $\mathrm{CO}_{2}$ (HU et al., 2010).

\subsubsection{Crescimento em diferentes temperaturas}

Além de estudar a influência da p $_{\mathrm{CO} 2}$ na capacidade de M1B-S capturar carbono, o presente trabalho também avaliou o desempenho da cepa em condições térmicas semelhantes às de gases de exaustão e de gás natural bruto. Para tanto, o seu crescimento foi investigado a 
$30^{\circ} \mathrm{C}, 40^{\circ} \mathrm{C}$ e $50^{\circ} \mathrm{C}\left(\mathrm{p}_{\mathrm{CO} 2}=0,1 \mathrm{~atm}\right)$. Os parâmetros de crescimento e de fixação de carbono para cada temperatura avaliada de M1B-S são descritas na Tabela 14 e na Tabela 15.

A análise do comportamento de M1B-S sob diferentes temperaturas demonstrou que, para as condições estudas, a máxima assimilação de $\mathrm{CO}_{2}$ em biomassa ocorre a $30^{\circ} \mathrm{C}\left(\mathrm{p}_{\mathrm{CO} 2}=\right.$ 0,1 atm) $(\mathrm{p}<0,05)$ (Figura 27 e Figura 28). Sob esta temperatura e após 8 dias de incubação, o cultivo de M1B-S resultou em 1,80 g/L de biomassa $\left(\mathrm{X}_{\text {máx }}\right)$ e em $1,25 \mathrm{~g} / \mathrm{L}$ de $\mathrm{CO}_{2}$ fixados $\left(\mathrm{F}_{\mathrm{CO} 2}\right.$, máx). A segunda maior fixação de carbono em biomassa ocorreu nos cultivos de M1B-S a $40^{\circ} \mathrm{C}$. Embora um acréscimo de $10^{\circ} \mathrm{C}$ na temperatura tenha provocado uma redução de $16 \%$ no rendimento em biomassa $\left(\mathrm{X}_{\text {máx }}=1,5 \mathrm{~g} / \mathrm{L}\right.$ a $\left.40^{\circ} \mathrm{C}\right)$, a cepa M1B-S ainda foi capaz de fixar 0,728 $\mathrm{g} / \mathrm{L}$ de $\mathrm{CO}_{2}$ durante 9 dias de cultivo.

Comparativamente, dados na literatura indicam que este comportamento de M1B-S entre $30^{\circ} \mathrm{C}$ e $40^{\circ} \mathrm{C}$ condiz com o gênero Alcanivorax e assemelha-se às demais bactérias quimioautotróficas estudadas na biomitigação de $\mathrm{CO}_{2}$. Por exemplo, a espécie Halomonas stevensii atinge máximos rendimentos em biomassa a $37^{\circ} \mathrm{C}\left(\mathrm{X}_{\text {máx }}=1,21 \pm 0,04 \mathrm{~g} / \mathrm{L}\right)$ e a $30^{\circ} \mathrm{C}$ $\left(\mathrm{X}_{\text {máx }}=0,85 \pm 0,03 \mathrm{~g} / \mathrm{L}\right.$ ) (MISHRA et al., 2017b; SILVEIRA, THOMPSON, 2014). Ainda, os resultados mostram que a cepa M1B-S possui uma maior termoestabilidade em relação a muitos microrganismos fotossintetizantes e, portanto, quando exposta a condições industriais reais, deve exibir uma capacidade de remoção de $\mathrm{CO}_{2}$ superior estes (YUE, CHEN, 2005).

Figura 27 - Curvas de crescimento da cepa M1B-S a $30^{\circ} \mathrm{C}, 40^{\circ} \mathrm{C}$ e $50^{\circ} \mathrm{C}\left(\mathrm{p}_{\mathrm{CO} 2}=0,1 \mathrm{~atm}\right)$. Crescimento em termos de a) densidade ótica $\left(\mathrm{DO}_{600 \mathrm{~nm}}\right)$ e de b) biomassa $(\mathrm{X}, \mathrm{g} / \mathrm{L})$.

a)

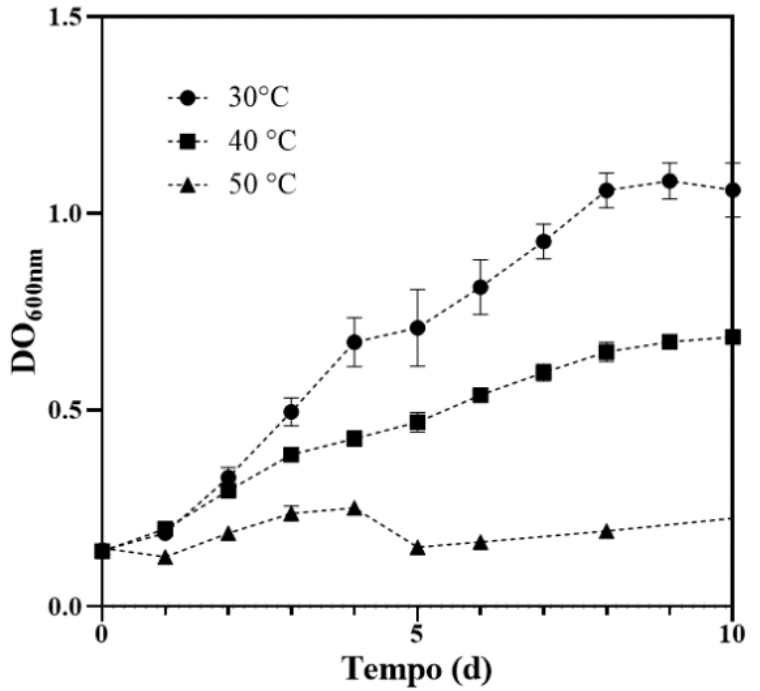

b)

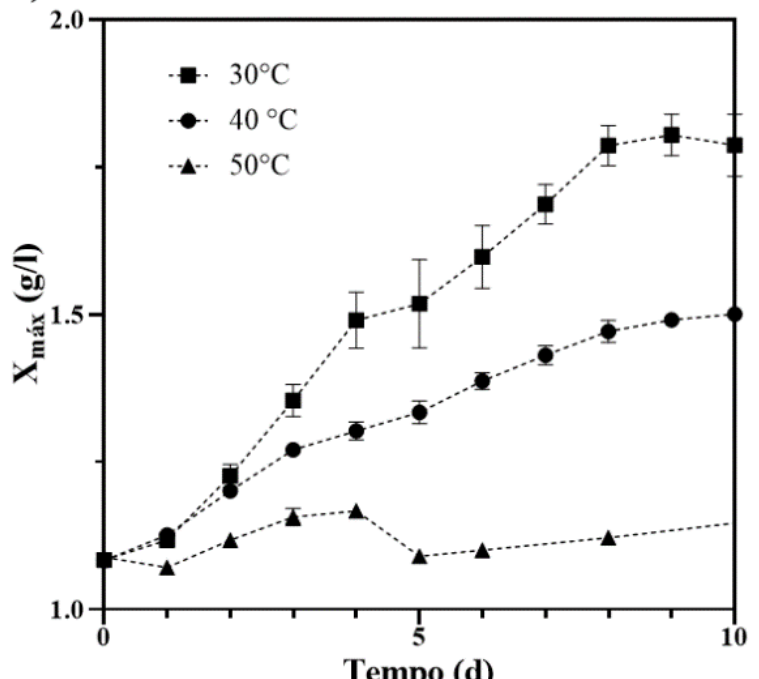


Figura 28 - Quantidade de $\mathrm{CO}_{2}$ fixada em biomassa pela cepa M1B-S a diferentes temperaturas $\left(30^{\circ} \mathrm{C}, 40^{\circ} \mathrm{C}\right.$ e $\left.50^{\circ} \mathrm{C}\right)$.

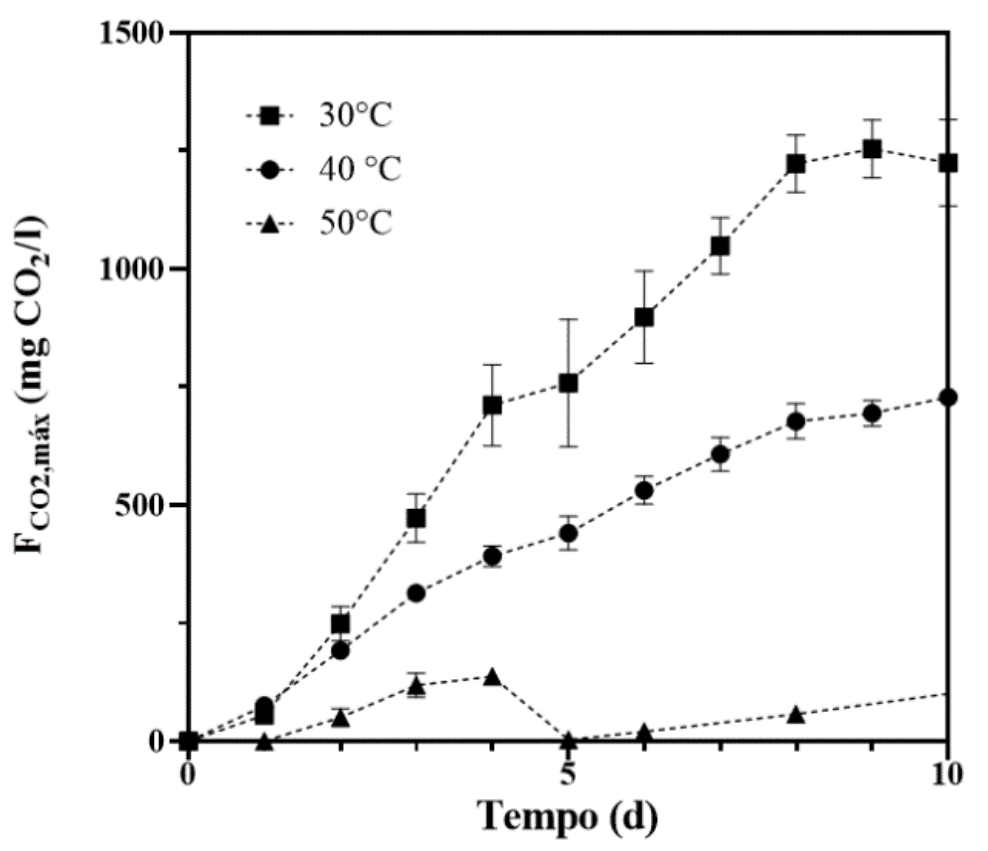

Apesar do comportamento favorável exibido por M1B-S entre $30^{\circ} \mathrm{C}$ e $40^{\circ} \mathrm{C}$, o acréscimo adicional na temperatura dos cultivos afetou significativamente o metabolismo desta cepa. Em todos os cultivos mantidos a $50^{\circ} \mathrm{C}$, o crescimento de M1B-S foi caracterizado por uma redução inicial na densidade ótica, seguida da formação de biofilme bacteriano. Através das medidas de concentração celular (DO) e da visualização, à olho nu, do meio de cultura, foi possível observar que a formação deste biofilme envolveu etapas distintas.

Inicialmente, entre o $1^{\circ}$ e o $4^{\circ}$ dia de incubação a $50^{\circ} \mathrm{C}$, agregados bacterianos de diferentes tamanhos formaram-se em todos os cultivos (Figura 29). A maioria destes agregados permaneceu em suspensão e somente os de maior diâmetro depositaram-se nos frascos de cultura. Simultaneamente, os dados de absorbância indicaram o aumento na concentração das células planctônicas, de modo que, em 4 dias, 1,16 g/L de biomassa foram obtidos em dispersão $\left(\mathrm{F}_{\mathrm{CO} 2}=0,187 \mathrm{~g} / \mathrm{L}\right)$ (Figura 27). Ao final deste intervalo de tempo, entretanto, verificou-se uma drástica redução na DO e a completa deposição de todos os agregados anteriormente suspensos. Assim, uma camada contínua de biofilme foi formada no fundo dos frascos de cultivo.

Entretanto, a concentração de células planctônicas voltou a aumentar lentamente a partir do $5^{\circ}$ dia de incubação. Consequentemente, pode-se inferir que o processo de formação e maturação do biofilme de M1B-S ocorre nos primeiros 5 dias de cultivo a $50^{\circ} \mathrm{C}$. Após este 
período, tem-se início o despendimento celular e as células bacterianas voltam a colonizar o meio de cultivo (Figura 29). Adicionalmente, passados 21 dias de incubação, nenhuma evidência de biofilme foi observada nos frascos de cultura. Com isso, os valores de DO indicaram a obtenção final de $1,28 \mathrm{~g} / \mathrm{L}$ de biomassa e a assimilação de $0,342 \mathrm{~g} / \mathrm{L}$ de $\mathrm{CO}_{2}$ na forma de material celular (Figura 30).

Figura 29 - Etapas da formação de biofilme em cultivos quimioautotróficos da cepa M1B-S a $50^{\circ} \mathrm{C}$ e $\mathrm{p}_{\mathrm{CO} 2}=0,1 \mathrm{~atm}$.
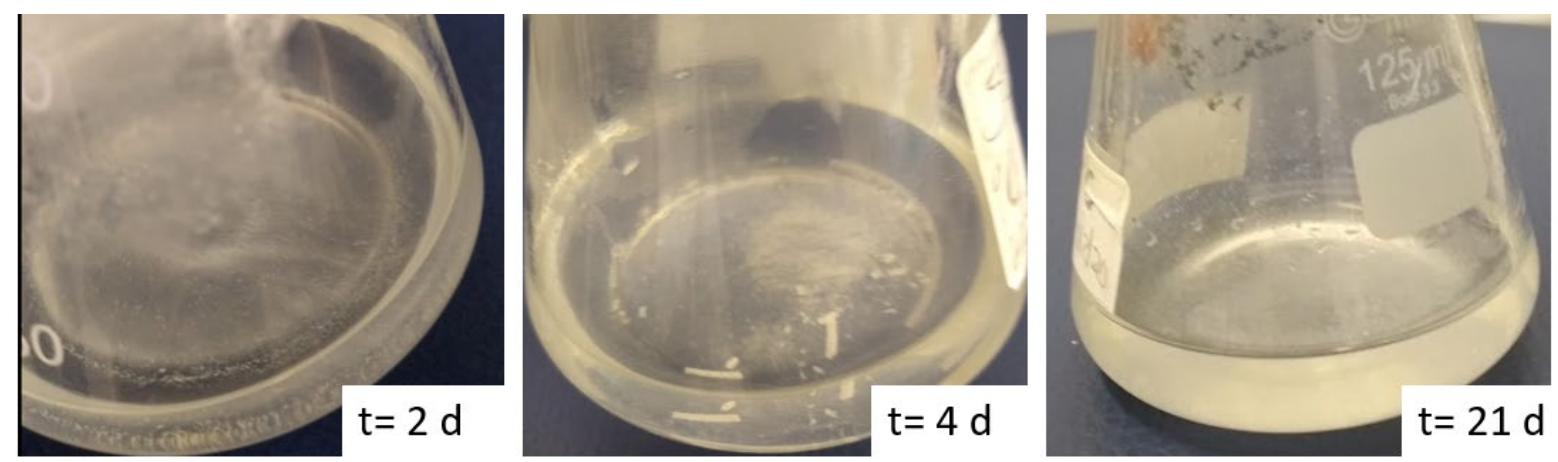

Figura $30-$ a) rendimento máximo em biomassa e b) quantidade máxima de $\mathrm{CO}_{2}$ fixada pela cepa M1B-S quando cultivada sob diferentes temperaturas.

a)

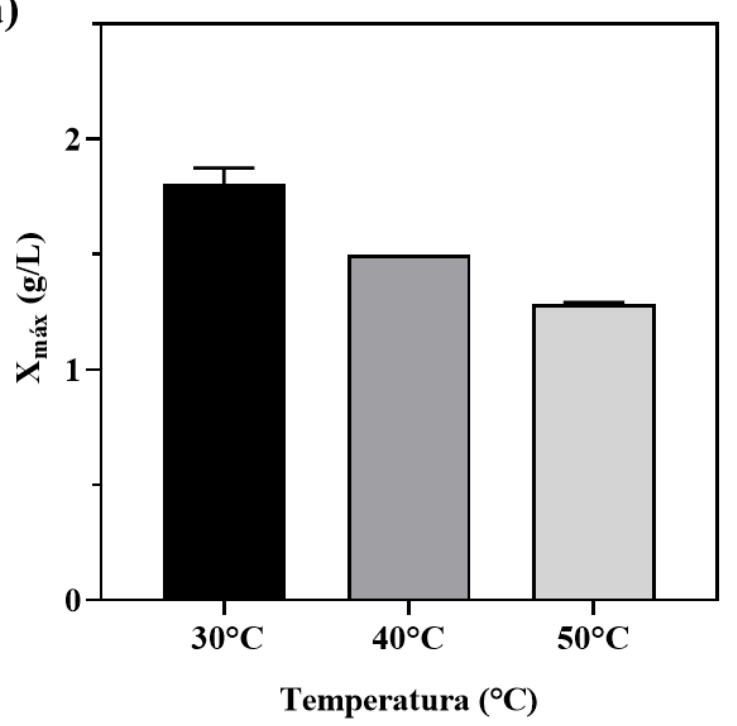

b)

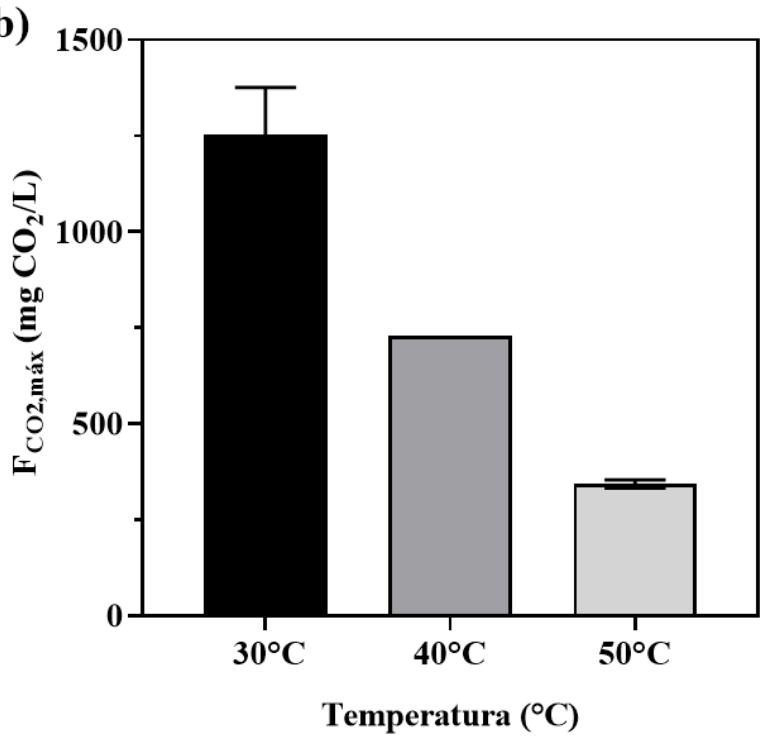

Conforme descrito anteriormente (Seção 5.4), o crescimento em biofilme exibido pela cepa M1B-S é comum aos membros do gênero Alcanivorax (OMAROVA et al., 2019). Em ambientes marinhos, as diferentes espécies de Alcanivorax tipicamente formam biofilmes na interface óleo-água de derramamentos de petróleo. Em tais circunstâncias, este tipo de 
crescimento é estimulado pela baixa disponibilidade relativa de $\mathrm{N}, \mathrm{P}$ e micronutrientes (OMAROVA et al., 2019; SILVEIRA, THOMPSON, 2014). Todavia, além da concentração de nutrientes, condições ambientais como $\mathrm{pH}, \mathrm{T}$, salinidade, pressão e presença de agentes antimicrobianos também são fatores que podem levar à formação de biofilme bacteriano (MUHAMMAD et al., 2020). Em vista disso e dos resultados aqui obtidos, pode-se sugerir que o crescimento em biofilme da bactéria M1B-S não foi induzido por condições nutricionais, mas sim, por estresses térmicos $\left(\mathrm{T} \geq 50^{\circ} \mathrm{C}\right)$.

Ademais, dadas as características do gênero Alcanivorax, sugere-se que a formação de biofilme por M1B-S esteja associada a uma assimilação adicional de $\mathrm{CO}_{2}$ na forma de EPS e biossurfactantes, por exemplo. Logo, a quantidade total de carbono fixada por esta cepa a $50^{\circ} \mathrm{C}$ é provavelmente superior à estimada através de medidas da biomassa. Assim, trabalhos futuros são necessários para determinar o TOC e a composição do meio de cultivo durante o crescimento de M1B-S.

Em relação às velocidades de crescimento, produtividades e taxas de fixação de $\mathrm{CO}_{2}$ em biomassa, os cultivos de M1B-S a $30^{\circ} \mathrm{C}$ também apresentaram melhores resultados $(\mathrm{p}<0,05)$. As velocidades de crescimento foram novamente computadas com o ajuste de modelos matemáticos, e os resultados são apresentados na Tabela 14 e Tabela 15. Para o cálculo de $\mu_{\text {máx }}$ nos ensaios a $50^{\circ} \mathrm{C}$, a curva de crescimento bacteriano foi dividida em duas partes. A primeira parte correspondeu ao crescimento entre os dias 1 e 4 de cultivo, ou seja, durante a formação de biofilme. Já a segunda parte levou em conta a dispersão das células planctônicas entre o $5^{\circ}$ e $21^{\circ}$ dia de incubação.

Similarmente aos experimentos sob diferentes concentrações de $\mathrm{CO}_{2}$, os modelos de Gompertz Modificado e Tipo Potência Modificado resultaram em melhores ajustes para o crescimento de M1B-S a $30{ }^{\circ} \mathrm{C}$ e $40^{\circ} \mathrm{C}$, respectivamente. Contudo, estes modelos não foram adequados para descrever a formação de biomassa (células planctônicas) a $50^{\circ} \mathrm{C}$. Neste caso, os valores de $\mu_{\text {máx }}$ foram estimados por meio da regressão linear da fase de crescimento exponencial.

Nos cultivos realizados a $30^{\circ} \mathrm{C}$, a cepa M1B-S exibiu uma velocidade máxima de crescimento igual a $0,514 \mathrm{~d}^{-1}$, atingindo produtividades máximas em biomassa e taxas máximas de fixação de $\mathrm{CO}_{2}$ entre o $3^{\circ}$ e $5^{\circ}$ dia de incubação $\left(\mathrm{P}_{\mathrm{b} \text {,máx }}=101,9 \mathrm{mg} / \mathrm{L} / \mathrm{d}\right.$ e $\mathrm{T}_{\mathrm{CO} \text {,máx }}=177,9$ $\mathrm{mg} / \mathrm{L} / \mathrm{d}$ ) (Figura 31 e Figura 32). Com a mudança da temperatura de incubação para $40^{\circ} \mathrm{C}, \mathrm{o}$ parâmetro $\mu_{\text {máx }}$ sofreu uma redução aproximada de $35 \%$ em relação ao dado acima reportado 
( $\mathrm{p}<0,05$ ). Consequentemente, a $40^{\circ} \mathrm{C}$ e 0,1 atm de $\mathrm{CO}_{2}$, a taxa de crescimento exponencial de M1B-S correspondeu a $0,33 \mathrm{~d}^{-1}$, assemelhando-se ao resultado observado nos ensaios sob $20 \%$ $\mathrm{CO}_{2}$ e $30^{\circ} \mathrm{C}$ (1 atm) (Tabela 13 e Tabela 15). Ainda, como consequência de uma menor velocidade de crescimento, as produtividades de M1B-S e as suas taxas de fixação de carbono a $40^{\circ} \mathrm{C}$ também foram inferiores às registradas a $30^{\circ} \mathrm{C}\left(\mathrm{P}_{\mathrm{b} \text {,máx }}=59,95 \mathrm{mg} / \mathrm{L} / \mathrm{d} \mathrm{e} \mathrm{T}_{\mathrm{CO} 2 \text {,máx }} 104,70\right.$ $\mathrm{mg} / \mathrm{L} / \mathrm{d})$.

Tabela 14 - Parâmetros $\mu_{\text {máx }}$ (intervalo de confiança assimétrico de 95\%) obtidos a diferentes temperaturas de cultivo e computados através do ajuste dos modelos de crescimento Logístico Modificado, Gompertz Modificado, Linear (fase exponencial) e Crescimento tipo Potência Modificado. A qualidade dos ajustes foi determinada com comparação entre os valores de $\mathrm{AIC}_{\mathrm{C}}$ de cada modelo. Os valores mais prováveis de $\mu_{\text {máx }}$ encontram-se em negrito.

\begin{tabular}{|c|c|c|c|c|c|}
\hline Temperatura & $\begin{array}{l}\text { Modelo de } \\
\text { crescimento }\end{array}$ & $\begin{array}{c}\mu_{\operatorname{máx}}(95 \% \text { IC }) \\
\left(d^{-1}\right)\end{array}$ & $\mathrm{AIC}_{\mathrm{c}}$ & $\Delta \mathrm{AIC}_{\mathrm{c}}$ & Probabilidade \\
\hline \multirow{4}{*}{$30^{\circ} \mathrm{C}$} & Logístico Modificado & $\begin{array}{c}0,4608 \\
(0,4043-0,5679)\end{array}$ & $-184,4$ & 0,6 & $27,02 \%$ \\
\hline & $\begin{array}{c}\text { Gompertz } \\
\text { Modificado }\end{array}$ & $\begin{array}{c}0,5142 \\
(0,4279-0,6285)\end{array}$ & $-185,0$ & 0 & $36,49 \%$ \\
\hline & $\begin{array}{c}\text { Linear } \\
\text { (fase exponencial) }^{* * *}\end{array}$ & $\begin{array}{c}0,4868 \\
(0,3824-0,5913)\end{array}$ & $-61,53$ & 123,5 & $\sim 0 \%$ \\
\hline & Tipo Potência & $\begin{array}{c}0,3868 \\
(0,3338-0,4470)\end{array}$ & $-185,5$ & 0 & $36,49 \%$ \\
\hline \multirow{4}{*}{$40^{\circ} \mathrm{C}$} & Logístico Modificado & $\begin{array}{c}0,3768 \\
(0,1631-0,5906)\end{array}$ & $-184,4$ & 4,1 & $9,95 \%$ \\
\hline & $\begin{array}{c}\text { Gompertz } \\
\text { Modificado }\end{array}$ & $\begin{array}{c}0,3504 \\
(0,2675-0,4333)\end{array}$ & $-184,9$ & 3,6 & $12,77 \%$ \\
\hline & $\begin{array}{c}\text { Linear } \\
\text { (fase exponencial) }^{* * *}\end{array}$ & $\begin{array}{c}0,3404 \\
(0,2938-0,3870)\end{array}$ & $-74,53$ & 114,0 & $\sim 0 \%$ \\
\hline & Tipo Potência & $\begin{array}{c}0,3264 \\
(0,2805-0,3926)\end{array}$ & $-188,5$ & 0 & $77,28 \%$ \\
\hline \multirow{4}{*}{$\begin{array}{c}50^{\circ} \mathrm{C} \\
\text { (durante formação }^{\text {do biofilme) }}{ }^{*}\end{array}$} & Logístico Modificado & $\begin{array}{c}0,6871 \\
(0,000-1,886)^{* *}\end{array}$ & $-49,62$ & 17,75 & $\sim 0 \%$ \\
\hline & $\begin{array}{c}\text { Gompertz } \\
\text { Modificado }\end{array}$ & $\begin{array}{c}0,4516 \\
(0,000-0,9248)^{* *}\end{array}$ & $-44,32$ & 23,05 & $0,02 \%$ \\
\hline & $\begin{array}{c}\text { Linear } \\
\text { (fase exponencial) }^{* * *}\end{array}$ & $\begin{array}{c}0,3147 \\
(\mathbf{0 , 2 3 4 1}-\mathbf{0 , 3 9 5 4 )}\end{array}$ & $-67,37$ & 0 & $99,98 \%$ \\
\hline & Tipo Potência & $\begin{array}{c}0,5730 \\
(0,000-1,489)^{* *}\end{array}$ & $-44,32$ & 23,05 & $\sim 0 \%$ \\
\hline
\end{tabular}

${ }^{*}$ Curva de crescimento das células planctônicas entre o $1^{\circ}$ e $4^{\circ}$ dia de incubação;

** Intervalos de confiança simétricos;

${ }^{* * *}$ Regressão linear somente com os dados da fase exponencial de crescimento; 
Figura 31 - a) produtividades em biomassa $\left(\mathrm{P}_{\mathrm{b}}, \mathrm{mg} / \mathrm{L} / \mathrm{d}\right)$ e b) taxas de fixação de $\mathrm{CO}_{2} \mathrm{em}$ biomassa $\left(\mathrm{T}_{\mathrm{CO} 2}, \mathrm{mg} / \mathrm{L} / \mathrm{d}\right)$ obtidos durante 10 dias de cultivo de M1B-S a $30^{\circ} \mathrm{C}, 40^{\circ} \mathrm{C}$ e $50^{\circ} \mathrm{C}\left(10 \% \mathrm{CO}_{2}\right.$, $1 \mathrm{~atm})$.

a)

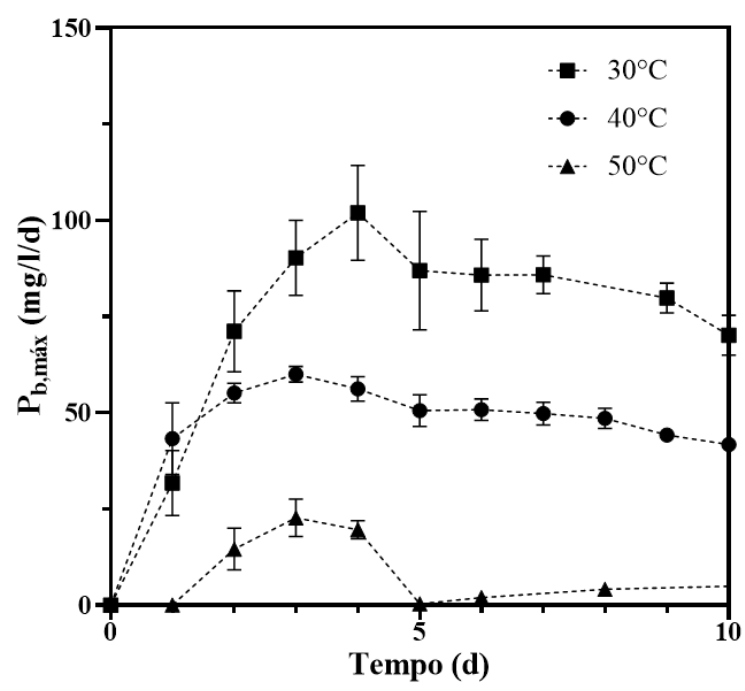

b)

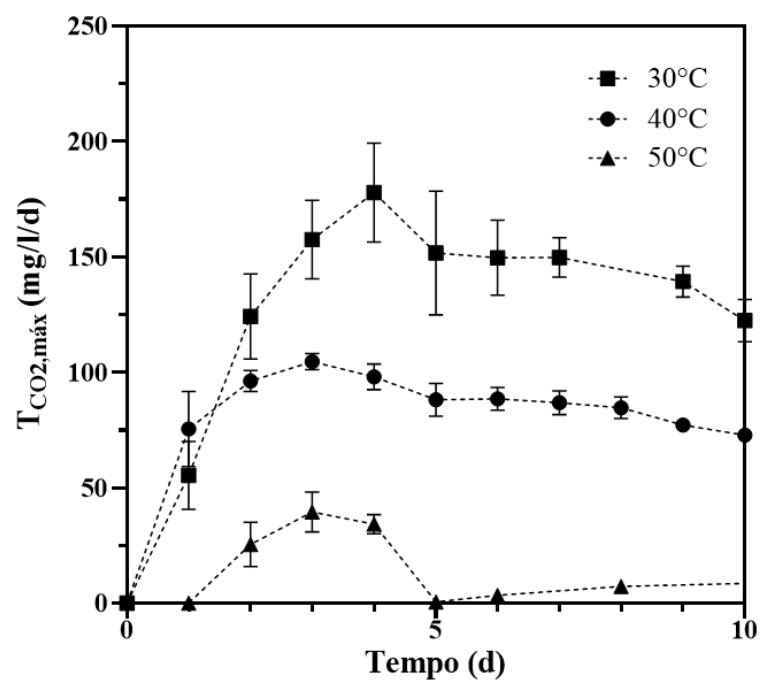

Figura 32 - a) produtividades máximas em biomassa $\left(\mathrm{P}_{\mathrm{b} \text { máx, }} \mathrm{g} / \mathrm{L} / \mathrm{d}\right)$ e b) taxas máximas de fixação de $\mathrm{CO}_{2}$ em biomassa $\left(\mathrm{T}_{\mathrm{CO} \text {,máx }}, \mathrm{mg} / \mathrm{L} / \mathrm{d}\right)$ obtidos nos cultivos de $\mathrm{M} 1 \mathrm{~B}-\mathrm{S}$ a $30^{\circ} \mathrm{C}, 40^{\circ} \mathrm{C}$ e $50^{\circ} \mathrm{C}($ $\left.10 \% \mathrm{CO}_{2}, 1 \mathrm{~atm}\right)$.
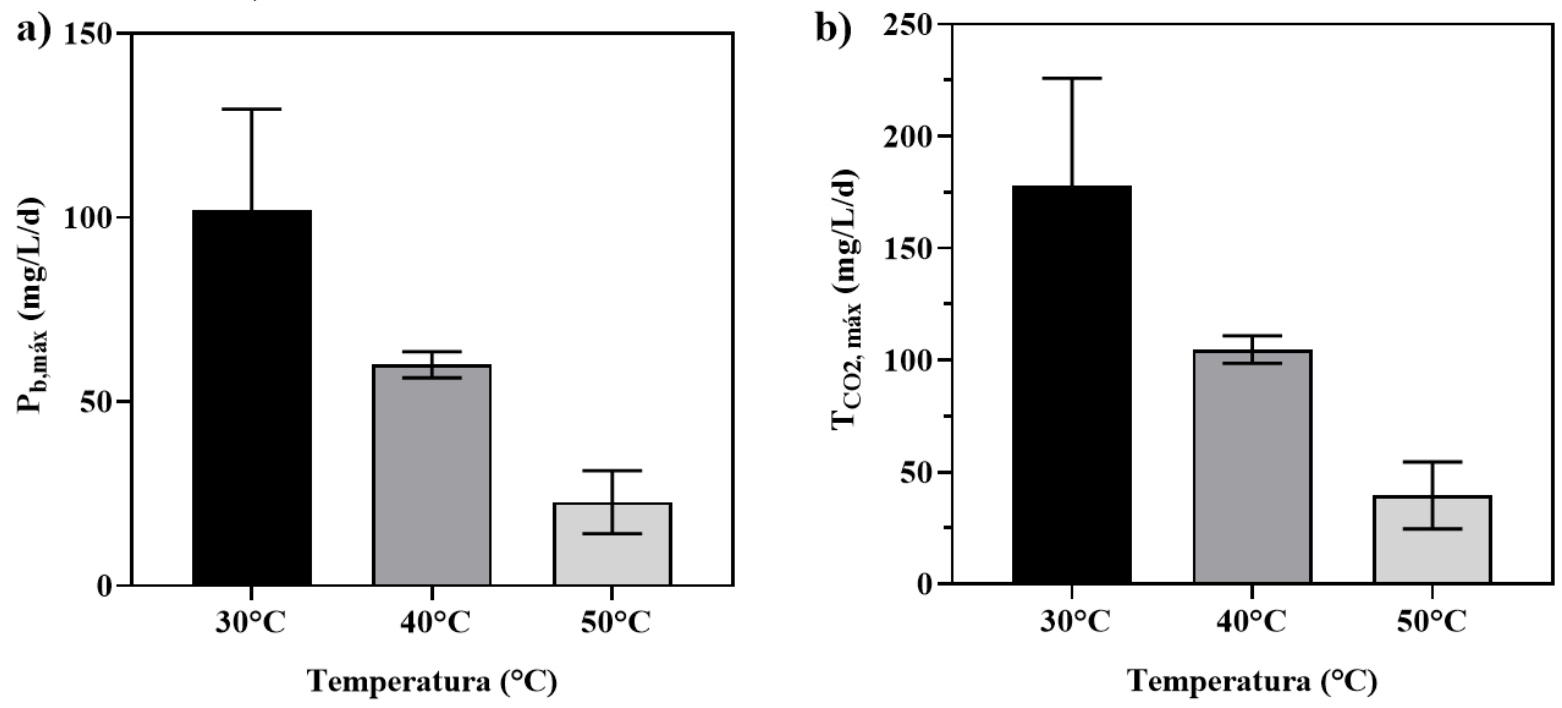

Adicionalmente, a regressão dos modelos de crescimento indicou igualdade estatística ( $\mathrm{p}=0,9636$ ) entre o valor de $\mu_{\text {máx }}$ a $40^{\circ} \mathrm{C}$ e o registrado durante os primeiros dias de incubação a $50^{\circ} \mathrm{C}$ (1-3 dias) (Tabela 15 15). Entretanto, esta estabilização não foi verificada para os parâmetros $\mathrm{P}_{\mathrm{b} \text {,máx }}$ e $\mathrm{T}_{\mathrm{CO} \text {,máx }}$ (Figura 28 e Figura 29 ). A $50^{\circ} \mathrm{C}$, a produtividade máxima em células planctônicas correspondeu a $22,67 \mathrm{mg} / \mathrm{L} / \mathrm{d}$, enquanto a fixação máxima de $\mathrm{CO}_{2}$ associada a estas células foi de apenas $39,56 \mathrm{mg} / \mathrm{L} / \mathrm{d}$. Novamente, considerando a formação de biofilme no meio de cultura e, consequentemente, a assimilação de $\mathrm{C}_{\mathrm{i}}$ em forma de EPS, estima- 
se que os reais valores de $\mathrm{P}_{\mathrm{b} \text {,máx }}$ e $\mathrm{T}_{\mathrm{CO} \text {,máx }}$ a $50^{\circ} \mathrm{C}$ sejam comparáveis aos de cultivos estabelecidos na temperatura $40^{\circ} \mathrm{C}$.

Tabela 15 - Velocidades máximas de crescimento $\left(\mu_{\text {máx }}\right)$, máxima biomassa $\left(\mathrm{X}_{\text {máx }}\right)$, quantidade máxima de $\mathrm{CO}_{2}$ fixado $\left(\mathrm{F}_{\mathrm{CO} 2 \text {,máx }}\right)$, máxima produtividade de biomassa $\left(\mathrm{P}_{\mathrm{b} \text {,máx }}\right)$ e máxima taxa de fixação de $\mathrm{CO}_{2}\left(\mathrm{~T}_{\mathrm{CO} 2 \text {,máx }}\right)$ obtidas nos cultivos de M1B-S sob diferentes temperaturas (médias $\pm \mathrm{SD}$ ).

\begin{tabular}{ccccccc}
\hline $\mathbf{T}\left({ }^{\circ} \mathbf{C}\right)$ & $\begin{array}{c}\boldsymbol{\mu}_{\text {máx }} \\
\left(\mathbf{d}^{-1}\right)\end{array}$ & $\begin{array}{c}\mathbf{t}_{\mathbf{d}} \\
(\mathbf{d})\end{array}$ & $\begin{array}{c}\mathbf{X}_{\text {máx }} \\
(\mathbf{g} / \mathbf{L})\end{array}$ & $\begin{array}{c}\mathbf{F}_{\mathbf{C O 2} \text { máx }} \\
(\mathbf{m g} / \mathbf{L})\end{array}$ & $\begin{array}{c}\mathbf{P}_{\mathbf{b}, \text { máx }} \\
(\mathbf{m g} / \mathbf{L} / \mathbf{d})\end{array}$ & $\begin{array}{c}\mathbf{T}_{\mathbf{C O} 2, \text { máx }} \\
(\mathbf{m g ~ C O} / \mathbf{L} / \mathbf{d})\end{array}$ \\
\hline 30 & $0,51 \pm 0,41$ & $1,36 \pm 0,26$ & $1,80 \pm 0,092$ & $1254 \pm 122$ & $101,9 \pm 27,5$ & $177,9 \pm 6,18$ \\
40 & $0,33 \pm 0,155$ & $2,12 \pm 0,35$ & $1,50 \pm 0,008$ & $728,1 \pm 38,3$ & $59,95 \pm 3,545$ & $104,7,0 \pm 30,4$ \\
50 & $0,31 \pm 0,161$ & $2,23 \pm 0,60$ & $1,28 \pm 0,006^{*}$ & $342,6 \pm 10,5^{*}$ & $22,67 \pm 8,57$ & $39,56 \pm 15,0$ \\
\hline
\end{tabular}

${ }^{*}$ Considerando a biomassa obtida após 21 dias de cultivo;

Os parâmetros acima expostos (Tabela 15) demonstram que, mesmo com menores taxas, a cepa M1B-S é capaz de fixar carbono sob temperaturas tão elevadas quanto $50^{\circ} \mathrm{C}$. Comparativamente, o crescimento de microalgas é frequentemente inibido entre $30^{\circ} \mathrm{C}-35^{\circ} \mathrm{C}$ (RAS, STEYER, BERNARD, 2013; WANG et al., 2008). Por exemplo, as espécies $A$. formosa, Ceratium furca e Chlorella pyrenoidosa crescem somente abaixo de $29,8^{\circ} \mathrm{C}, 32,1^{\circ} \mathrm{C}$ e $45,8^{\circ} \mathrm{C}$, respectivamente (RAS, STEYER, BERNARD, 2013).

Além disso, análises da literatura evidenciam que temperaturas acima das condições ótimas de crescimento tendem a afetar de maneira mais significativa as microalgas do que a cepa M1B-S (WANG et al., 2008; YUE, CHEN, 2005). Em um dos estudos avaliados, Chinnasamy et al. (2009) concluíram que a $50^{\circ} \mathrm{C}$ o valor de $\mu_{\text {máx }}$ da cepa Chlorella vulgaris ARC 1 é $70 \%$ inferior ao registrado a $30^{\circ} \mathrm{C}$. Para esta mesma variação de temperatura, a taxa de crescimento de M1B-S sofreu uma redução de apenas 39\%.

O desempenho de M1B-S sob diferentes condições térmicas também pode ser comparado com o de bactérias autotróficas utilizadas para estudar a fixação de $\mathrm{CO}_{2}$. Em relação a algumas espécies, tais como YN-1, Acidiferrobacter thiooxydan e as cepas de Beggiatoa ssp. isoladas por Nelson et al. (1989), M1B-S demonstra maior resistência a elevadas temperaturas. Apesar dos microrganismos citados apresentarem crescimento a $\mathrm{T}>30^{\circ} \mathrm{C}$, pouca ou nenhuma fixação de $\mathrm{CO}_{2}$ foi verificada em seus cultivos mantidos a $40^{\circ} \mathrm{C}-50^{\circ} \mathrm{C}$ (BAE et al., 2001; HALLBERG, HEDRICH, JOHNSON, 2010; NELSON et al., 1989). Por outro lado, em comparação com Hydrogenophilus thermoluteolus TH-1 ( $\mu_{\operatorname{máx}}=0,68 \mathrm{~h}^{-1}$ a $\left.50^{\circ} \mathrm{C}\right)$ e demais bactérias termófilas, o crescimento de M1B-S a $40-50^{\circ} \mathrm{C}$ é caracterizado por menores 
velocidades de crescimento e menores capacidades de capturar carbono (NGUYEN et al., 2019; MISHRA et al., 2017b; NELSON et al.,1989).

Em suma, além de apresentar crescimento autotrófico na ausência de luz e em concentrações de $\mathrm{CO}_{2}$ iguais ou superiores a $5 \%$, a cepa M1B-S é capaz de capturar $\mathrm{CO}_{2}$ e convertê-lo em biomassa entre $30^{\circ} \mathrm{C}$ a $50^{\circ} \mathrm{C}$. Consequentemente, esta bactéria representa uma potencial alternativa aos atuais processos de CCS e CCU, sejam eles biológicos ou físicoquímicos (KWON, 2015; BAE et al., 2001).

Ademais, as $\mathrm{p}_{\mathrm{CO} 2}$ e temperaturas na qual M1B-S foi capaz de se desenvolver sustentam uma futura aplicação na captura e utilização do $\mathrm{CO}_{2}$ proveniente de gases de combustão e de gás natural bruto. De modo específico, o crescimento de M1B-S em um meio salino pobre como o ASW pode facilitar, ainda, o uso comercial deste microrganismo no tratamento de gases em plataformas petrolíferas offshore. Neste caso, a água do mar poderia ser utilizada como um meio de cultura, reduzindo, assim, os custos de operação do processo.

\subsubsection{Consumo de tiossulfato e nitrato}

Em adição a comprovar a sua capacidade de crescer e fixar $\mathrm{C}_{\mathrm{i}}$ sob diferentes concentrações de $\mathrm{CO}_{2}$ e temperaturas, a caracterização da cepa M1B-S avaliou o consumo de tiossulfato como fonte de energia para o metabolismo quimiautotrófico.

Análises de cromatografia iônica (CI) dos cultivos de M1B-S a 20\% $\mathrm{CO}_{2}\left(30^{\circ} \mathrm{C}\right)$ demonstram uma redução na concentração de $\mathrm{S}_{2} \mathrm{O}_{3}{ }^{-2}$ acompanhada do crescimento bacteriano (DO) $(\mathrm{p}<0,05)$ (Figura 33). De acordo com estas análises, para cada $1 \mathrm{~mol}$ de tiossulfato $\left(\mathrm{S}_{2} \mathrm{O}_{3}{ }^{-}\right.$ ${ }^{2}$ ) consumido, aproximadamente $26,7 \mathrm{~g}$ de biomassa bacteriana (massa seca) foram produzidos. Além disso, em paralelo ao consumo de tiossulfato e ao crescimento de M1B-S, observou-se o acréscimo de $0,25 \mathrm{~g} / \mathrm{L}$ na concentração de íons sulfato $\left(\mathrm{S}_{2} \mathrm{O}_{4}{ }^{-2}\right)$ no meio de cultura (Figura 33). Esta variação na concentração de $\mathrm{SO}_{4}{ }^{-2}$ corresponde à oxidação de apenas $8 \%$ de todo o tiossulfato consumido durante o ensaio $(1,764 \mathrm{~g} / \mathrm{L})$. 
Figura 33 - Concentração de íons tiossulfato $\left(\mathrm{S}_{2} \mathrm{O}_{3}{ }^{-2}\right)$ e sulfato $\left(\mathrm{SO}_{4}^{-2}\right)$ durante o crescimento da cepa M1B-S sob $20 \% \mathrm{CO}_{2}$.

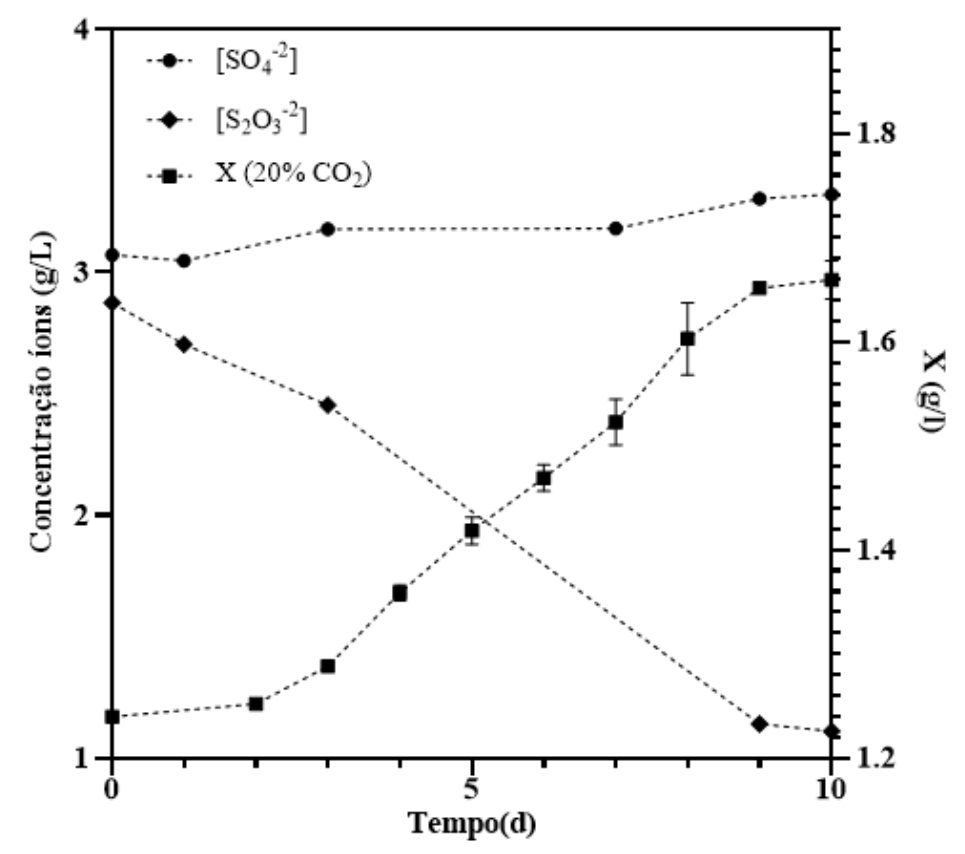

De modo geral, a oxidação bacteriana de tiossulfato resulta majoritariamente em sulfato e tetrationato, podendo também levar à eventual formação de sulfito e outros compostos inorgânicos de enxofre (MASUDA et al., 2010). Desta forma, e sendo o $\mathrm{S}_{2} \mathrm{O}_{3}{ }^{-2}$ a única possível fonte de energia fornecida para a bactéria M1B-S, sugere-se que esta cepa é capaz de exibir metabolismo quimiautotrófico, utilizando tiossulfato como doador de elétrons. Não obstante, a cepa aparenta ser capaz de oxidar tiossulfato a sulfato e a outras substâncias contendo enxofre.

Além da provável oxidação bacteriana de $\mathrm{S}_{2} \mathrm{O}_{3}{ }^{-2}$, a análises de íons no meio de cultura revelaram que todo o $\mathrm{NO}_{3}{ }^{-}$inicialmente adicionado no cultivo de M1B-S havia sido consumido ao final do período de incubação (10 dias). Nestes ensaios, também foi possível identificar a formação de íons $\mathrm{NO}_{2}{ }^{-}$e de bolhas de gás durante a fase de crescimento exponencial da bactéria, o que evidencia o já sugerido comportamento desnitrificante de M1B-S.

\subsection{DIREÇÕES FUTURAS}

Considerando os promissores resultados obtidos no presente trabalho, pode-se afirmar que os objetivos inicialmente propostos foram alcançados. Em especial, os esforços empreendidos culminaram no isolamento de 7 bactérias capazes de fixar $\mathrm{CO}_{2}$ em concentrações 
típicas de gases de exaustão e de gás natural bruto $\left(>5 \% \mathrm{v} / \mathrm{v} \mathrm{CO}_{2}\right)$. Apesar disso, a pesquisa aqui realizada apresenta apenas um caráter inicial, de modo que novos estudos são necessários a fim de se obter uma tecnologia adequada para a indústria.

Assim, visando a continuação deste projeto, alguns dos possíveis ensaios a serem desenvolvidos são elencados a seguir.

\subsubsection{Estudo de todas as cepas isoladas}

Dentre as 7 bactérias isoladas ao final do projeto, apenas uma foi identificada e caracterizada. Consequentemente, sugere-se que estudos futuros investiguem as demais cepas isoladas e avaliem a sua capacidade de capturar carbono. Idealmente, estes estudos devem empregar gases reais (gás de exaustão/natural) ou, então, misturas gasosas que contenham $\mathrm{CO}_{2}$ e compostos como $\mathrm{NO}_{x} \mathrm{SO}_{x}, \mathrm{CH}_{4}$ e $\mathrm{C}_{2} \mathrm{H}_{6}$. Ademais, outras sugestões são: 1) estudar o crescimento de todas as cepas sob diferentes pressões de operação e maiores concentrações de $\mathrm{CO}_{2}$; 2) realizar experimentos em biorreatores e 3) explorar a produção de bioprodutos derivados da biomassa ou secretados pelas células.

\subsubsection{Estudos adicionais com a cepa M1B-S}

Além do crescimento das outras cepas isoladas, trabalhos futuros também podem explorar muitos aspectos tecnológicos de M1B-S, tais como:

a) otimização do meio de cultivo: a velocidade de crescimento de M1B-S e a sua capacidade de fixar $\mathrm{CO}_{2}$ podem ser maximizadas através de modificações no $\mathrm{pH}$ e na composição do meio de cultivo. Para tanto, as concentrações de $\mathrm{NO}_{3}{ }^{-}, \mathrm{S}_{2} \mathrm{O}_{3}{ }^{-2}, \mathrm{~N}, \mathrm{P}, \mathrm{NaCl}$ e de elementos traço podem ser otimizadas e ainda, o meio pode ser suplementado com vitaminas, caso necessário. Em tais ensaios de otimização, o cálculo de $\mathrm{F}_{\mathrm{CO} 2}$ e $\mathrm{T}_{\mathrm{CO} 2}$ deve levar em consideração o teor de carbono da biomassa e das biomoléculas secretadas no meio de cultura. Adicionalmente, sugere-se a realização dos testes em biorreatores agitados (batelada) e com volumes superiores aos aqui empregados. 
b) conversão de $\mathrm{CO}_{2}$ em bioprodutos: a síntese de bioprodutos, seja diretamente pela cepa M1B-S ou a partir da sua biomassa, também pode ser estudada. Inicialmente, pode-se verificar a capacidade de M1B-S sintetizar moléculas e materiais característicos do gênero Alcanivorax. Desta forma, produtos a serem avaliados incluem triacigliceróis, ésteres de cera, bioplásticos (PHA), EPS, biossurfactantes e enzimas (esterases, alcanohidroxilases, etc.) (KALSCHEUER et al., 2007; SILVEIRA, THOMPSON, 2014). A análise quantitativa e qualitativa destes e de outros bioprodutos de M1B-S pode ser realizada através de ferramentas como genoma, proteoma, metaboloma e secretoma. Ainda, em relação à biomassa de M1B-S, esta pode ser avaliada para a produção de biodiesel, bio-óleos e ração animal, por exemplo (MATASSA et al., 2016; KUMAR et al., 2018; YANIK et al., 2013). A escolha do melhor uso para a biomassa deve levar em conta a sua composição em termos de carbono, lipídeos, hidrocarbonetos e proteínas. Desta forma, ensaios futuros devem determinar a fórmula química da cepa M1B-S $\left(\mathrm{C}_{\mathrm{w}} \mathrm{H}_{\mathrm{x}} \mathrm{O}_{\mathrm{y}} \mathrm{N}_{\mathrm{z}}\right)$ e a concentração relativa de macromoléculas em suas células.

c) cultivos de M1B-S sob P >1 atm: pode-se determinar o efeito que a pressão total do sistema (cultivo) exerce no crescimento de M1B-S. Assim, podem ser consideradas pressões superiores a 1 atm e concentrações de $\mathrm{CO}_{2}$ constantes $\left(20 \%, \mathrm{p}_{\mathrm{CO} 2} \geq 0,2 \mathrm{~atm}\right)$. Comparativamente, pode-se investigar também a capacidade de M1B-S capturar carbono a $\mathrm{P}=1 \mathrm{~atm}$, mas sob maiores pressões parciais de $\mathrm{CO}_{2}\left(0,2<\mathrm{p}_{\mathrm{CO} 2}<1 \mathrm{~atm}\right)$.

d) crescimento de M1B-S sob gás de exaustão/gás natural simulado (ou real): o crescimento de M1B-S pode ser estudado em cultivos mantidos sob misturas gasosas que simulem as reais composições de gases de exaustão e gás natural. Portanto, além de $\mathrm{CO}_{2}$ e eventualmente $\mathrm{N}_{2} / \mathrm{O}_{2}$, estas misturas podem conter compostos como $\mathrm{CH}_{4}, \mathrm{C}_{2} \mathrm{H}_{6}$, $\mathrm{NO}_{\mathrm{x}}$ e $\mathrm{SO}_{\mathrm{x}}$. Com tais ensaios será possível prever, com maior acurácia, o comportamento de M1B-S ( $\mu_{\text {máx }}, \mathrm{X}, \mathrm{P}_{\mathrm{b}}, \mathrm{T}_{\mathrm{CO} 2}$ e $\mathrm{F}_{\mathrm{CO} 2}$ ) em cultivos industriais.

e) cultivos de M1B-S em maior escala (biorreatores): visando aplicações industriais, o desempenho e a cinética de crescimento de M1B-S devem ser determinados em cultivos de maior volume ( $>1$ L). Para isso, diferentes tipos de reatores e modos de operação podem ser utilizados, a citar os tanques agitados (batelada, batelada alimentada e/ou CSTR), as colunas de borbulhamento (BCBs) e os reatores gas-liftt (GLBs) (DORAN, 
1995). Além disso, devido a formação de biofilme pela bactéria M1B-S, reatores com células suportadas também podem ser cogitados para os experimentos (e.g. reatores de leito fixo, fluidizado, gotejante, etc.) (DORAN, 1995; PEREIRA, BOM, FERRARA, 2008). Quanto às condições de operação de cada reator, parâmetros como fluxo de alimentação de gás, agitação, temperatura e taxa de diluição podem ser alterados a fim de maximizar $\mathrm{F}_{\mathrm{CO} 2}$ e $\mathrm{T}_{\mathrm{CO} 2}$. Adicionalmente, pode-se realizar a modelagem matemática dos biorreatores.

f) análises "ômicas": metodologias ômicas, como o genoma, transcriptoma, proteoma e metaboloma, podem ser empregadas tanto para estudar o metabolismo de M1B-S sob diferentes condições de cultivos, quanto para elucidar o mecanismo envolvido no crescimento autotrófico desta cepa. Tais metodologias também permitirão uma melhor identificação da cepa M1B-S e dos genes/características que a distinguem dos demais membros do gênero Alcanivorax, até então reportados como heterótrofos obrigatórios. 


\section{CONCLUSÃO}

Ao final deste trabalho, 15 cepas bacterianas foram isoladas a partir de sedimentos marinhos coletados a $550 \mathrm{~m}$ de profundidade no Estreito de Bransfield, Antártica. As cepas isoladas foram capazes de sobreviver no escuro, em água do mar artificial, a $30^{\circ} \mathrm{C}$ e sob atmosfera de ar e $30 \% \mathrm{CO}_{2}$ (1 atm). Dentre as 15 cepas originalmente selecionadas, 7 apresentam crescimento quimiautotrófico a $20 \% \mathrm{CO}_{2}$ (1 atm), utilizando $\mathrm{S}_{2} \mathrm{O}_{3}{ }^{-}$e/ou $\mathrm{NH}_{4}{ }^{+}$como fontes de energia. Estas bactérias, além de consumirem $\mathrm{CO}_{2}$, também demonstraram a capacidade de utilizar carbono orgânico, alternativa e simultaneamente.

Os cultivos quimioautotróficos das 7 cepas selecionadas foram caracterizados por velocidades de crescimento comparáveis a demais microrganismos empregados na fixação biológica de carbono. Assim, conclui-se que as bactérias aqui selecionadas constituem promissoras alternativas para mitigar as emissões industriais de $\mathrm{CO}_{2}$.

Em adição a seleção de bactérias quimioautotróficas, o presente estudo caracterizou o crescimento de uma destas, a cepa M1B-S. Esta cepa, identificada como pertencente ao gênero Alcanivorax, demostrou ser capaz de crescer em condições relevantes para processos industriais, ou seja, em temperaturas de $30^{\circ} \mathrm{C}$ a $50^{\circ} \mathrm{C}$ e em concentrações de $\mathrm{CO}_{2}$ de $5 \% \mathrm{CO}_{2}$ a $20 \% \mathrm{CO}_{2}$. Especificamente, os máximos rendimentos em biomassa e a máxima fixação de carbono por M1B-S foram obtidos a $5 \%$ e $10 \% \mathrm{CO}_{2}\left(30^{\circ} \mathrm{C}\right)$.

O desempenho cinético de M1B-S, por sua vez, demonstrou ser inversamente afetado por temperaturas acima de $30^{\circ} \mathrm{C}$ e concentrações de $\mathrm{CO}_{2}$ superiores a $5 \%$ (1 atm). Logo, culturas mantidas sob $\mathrm{p}_{\mathrm{CO} 2}$ de 0,05 atm e a $30^{\circ} \mathrm{C}$ exibiram as maiores velocidades de crescimento $\left(1,3 \mathrm{~d}^{-1}\right)$ e maiores taxas de fixação de carbono (308 mg/L/d). Não obstante, mesmo quando submetida a condições de cultivo não ideais, esta cepa caracterizou-se por valores de $\mu_{\text {máx }}$ e $\mathrm{T}_{\mathrm{CO} 2}$ comparáveis aos de microalgas e demais bactérias autotróficas.

Adicionalmente, análises realizadas no meio de cultivo de M1B-S indicaram que esta bactéria consome $\mathrm{S}_{2} \mathrm{O}_{3}{ }^{-}$como fonte de energia e reduz $\mathrm{NO}_{3}{ }^{-}$. Desta forma, sugere-se que M1BS possa ser empregada na remoção simultânea de $\mathrm{CO}_{2}$ e $\mathrm{NO}_{x}$ de gases de combustão e de gás natural bruto, especialmente em indústrias petrolíferas.

Em suma, o trabalho aqui desenvolvido cumpriu com os objetivos incialmente propostos e certamente deixa a sua contribuição para as áreas de CCU e de biotecnologia. Ainda, este projeto torna-se um dos primeiros a estudar bactérias marinhas antárticas na captura industrial de $\mathrm{CO}_{2}$ e o primeiro a reportar o crescimento autotrófico de uma cepa do gênero Alcanivorax. 


\section{REFERÊNCIAS BIBLIOGRÁFICAS}

ANAND, A.; RAGHUVANSHI, S.; GUPTA, S. Trends in carbon dioxide $\left(\mathrm{CO}_{2}\right)$ fixation by microbial cultivations. Current Sustainable/Renewable Energy Reports, 2020.

ANP. Estudo sobre o aproveitamento do gás natural no pré-sal. ANP, 2020. Disponível em< http://www.anp.gov.br/arquivos/estudos/aproveitamento-gn-pre-sal.pdf $>$. Acesso em: $11 \mathrm{abr}$. 2020.

API. Compendium of greenhouse gas emissions methodologies for the oil and natural gas industry. American Petroleum Institute - API, p. 1-807, 2009.

$\mathrm{BAE}, \mathrm{S}$. et al. Isolation and characterization of $\mathrm{CO}_{2}$-fixing hydrogen oxidizing marine bacteria. Journal of Bioscience and Bioengineering, v. 91, n. 5, p. 442-448, 2001.

BERG, I.A.; KOCKELKORN, D.; BUCKEL, W.; FUCHS, G. A 3-hydroxypropionate/4hydroxybutyrate autotrophic carbon dioxide assimilation pathway in archaea. Science, v. 318, n. 5857, p. 1782-1786, 2007.

BERNARDEZ, L.A.; LIMA, L.R.P.A. Improved method for enmerating sulfate-reducin bacteria using optical density. MethodsX, v.2, p. 249-255, 2015.

BHARTI, R. K.; SRIVASTAVA, S.; THAKUR, I. S. Production and characterization of biodiesel from carbon dioxide concentrating chemolithotrophic bacteria, Serratia sp. ISTD04. Bioresource Technology, v.153, p. 189-197, 2014.

BLANCO, V.L.A. Diagnóstico de emissões de gases de efeito estufa em plataformas FPSO. 2016. 124 p. Tese (Mestrado em Planejamento de Sistemas Energéticos) - Faculdade de Engenharia Mecânica, Universidade Estadual de Campinas, Campinas, 2016.

BLAIZE, J.F.; SUTER, E.; CORBO, C.P. Serial dilutions and plating: microbial enumeration. JoVE Science Education Database, Cambridge, 2020. Disponível em< https://www.jove.com/science-education/10507/serial-dilutions-and-plating-microbialenumeration>. Acesso em: 21 de abr. 2020.

BRZESZCZ, J.; KASZYCKI, P. Aerobic bacteria degrading both n-alkanes and aromatic hydrocarbons: an undervalued strategy for metabolic diversity and flexibility. Biodegradation, v. 29, p. 359-407, 2018.

BRIGHAM, C. Perspectives for the biotechnological production of biofuels from $\mathrm{CO}_{2}$ and $\mathrm{H}_{2}$ using Ralstonia eutropha and other 'Knallgas' bacteria. Applied Microbiology and Biotechnology, 2019.

BRUNS, A.; BERTHE-CORTI, L. Fundibacter jadensis gen. nov., sp. nov., a new slightly halophilic bacterium, isolated from intertidal sediment. International Journal of Systematic Bacteriology, v. 49, n. 2, p. 441-448, 1999. doi:10.1099/00207713-49-2-441

CAIT. CAIT Climate Data Explorer: Country greenhouse gas emissions. World Resources Institute, 2019. Disponível em<http://cait.wri.org>. Acesso em: 03 abr. 2020. 
CARDOSO, L.O.B. Produção de Polihidroxibutirato (PHB) por Bactérias Metilotróficas. 2017.79 p. Dissertação (Mestrado em Engenharia Química) - Escola Politécnica, Universidade de São Paulo, São Paulo, 2017.

CARR, S.A. et al. Bacterial abundance and composition in marine sediments beneath the Ross Ice Shelf, Antarctica. Geobiology, v.11, n.04, p. 377-395, 2013.

CHAN, W.N. et al. Assessment of $\mathrm{CO}_{2}$ emission mitigation for a Brazilian oil refinery. Brazilian Journal of Chemical Engineering, v. 33, n. 04, p. 835-850, 2016.

$\mathrm{CHEAH}, \mathrm{W}$. Y. et al. Biosequestration of atmospheric $\mathrm{CO}_{2}$ and flue gas-containing $\mathrm{CO}_{2}$ by microalgae. Bioresource Technology, v. 184, p.190-201, 2015.

CHEAH, W.Y. et al. Biorefineries of carbon dioxide: from carbon capture \& storage (CCS) to bioenergies production. Bioresource Technology, v. 215, p. 346-356, 2016.

CHEN, Y-.L. et al. Obtaining long 16S rDNA sequences using multiple primers and its application on dioxin-containing samples. BMC Bioinformatics, v. 16, s.18, S13, 2015. doi:10.1186/1471-2105-16-S18-S13

CHINNASAMY, S. et al. Biomass production potential of a wastewater alga Chlorella vulgaris $A R C 1$ under elevated levels of $\mathrm{CO}_{2}$ and temperature. International Journal of Molecular Sciences, v.10, p. 518-532, 2009.

COLLINS, M. et al. Long-term Climate Change: Projections, Commitments and Irreversibility. In: _. STOCKER, T.F.; QIN, D.; PLATTNER, G.-K.; TIGNOR, M.; ALLEN, S.K.; BOSCHUNG, J.; NAUELS, A.; XIA, Y.; BEX; V.; MIDGLEY, P.M (eds.) Climate Change 2013: The Physical Science Basis. Contribution of Working Group I to the Fifth Assessment Report of the Intergovernmental Panel on Climate Change. Cambridge, United Kingdom and New York: Cambridge University Press, 2013.

CORRADINI, M.G.; PELEG, M. Estimating non-isothermal bacterial growth in foods from isothermal experimental data. Journal of Applied Microbiology, v.99, p. 187-200, 2005.

CUÉLLAR-FRANCA, R.M; AZAPAGIC, A. Carbon capture, storage and utilisation technologies: a critical analysisand comparison of their life cycle environmental impacts. Journal of $\mathrm{CO}_{2}$ Utilization, v. 9, p. 82-102, 2015.

CURIE, M. AZquotes. Disponível em<https://www.azquotes.com/author/3506-Marie_Curie>. Acesso em: 25 de abril de 2021.

DE MORAIS, M.G; COSTA, J.A.V. Isolation and selection of microalgae from coal fired thermoelectric power plant for biofixation of carbon dioxide. Energy Conversion and Management, v.48, p. 2169-2173, 2007.

DORAN, P.M. Bioprocess engineering principles. 1. ed., London: Academic Press Limited, 1995.

EMERSON, D.F. et al. Enhancing $\mathrm{H}_{2}$-dependent growth of and $\mathrm{CO}_{2}$ fixation by Clostridium ljungdahlii through nitrate supplementation. Biotechnology and Bioengineering, v. 111, n.2, p. 294-306, 2019. 
EPE. Estudo sobre o aproveitamento do gás natural do pré-sal. ANP/EPE, 2020. Disponível em< http://www.anp.gov.br/arquivos/estudos/aproveitamento-gn-pre-sal.pdf $>$. Acesso em: 07 de abr. 2020.

ESPARZA, M. et al. Effect of $\mathrm{CO}_{2}$ concentration on uptake and assimilation of inorganic carbon in the extreme acidophile Acidithiobacillus ferrooxidans. Frontiers in Microbiology, v. 10 , n. 603,2019 . doi:10.3389/fmicb.2019.00603

FARAMAWY, S.; ZAKI, T., SAKR, A.A.-E. Natural gas origin, composition and processing: a review. Journal of Natural Gas Science and Engineering, v. 34, p. 34-54, 2016.

FERGUSON, S. J. Denitrification and its control. Antonie van Leeuwenhoek, v. 66, p. 89$110,1994$.

FRANCO, D.C. Metagenomics reveals potential for dark carbon fixation at Hook Ridge, Bransfield Strait. ISME17 Leipzig, 2017. DOI: 10.13140/RG.2.2.25879.42405

GARCIA-GONZALEZ, L. et al. Sustainable autotrophic production of polyhydroxybutyrate (PHB) from $\mathrm{CO}_{2}$ using a two-stage cultivation system. Catalysis Today, 2014.

GE, M.; FRIEDRICH, J. 4 charts explain greenhouse gas emissions by countries and sectors. WRI, 2020. Disponível em<https://www.wri.org/blog/2020/02/greenhouse-gas-emissions-bycountry-sector>. Acesso em: 03 abr. 2020.

GHOSH, W.; DAM, B. Biochemistry and molecular biology of lithotrophic sulfur oxidation by taxonomically and ecologically diverse bacteria and archaea. FEMS Microbiology Reviews, v. 33, p. 999-1043, 2009.

GOTTSCHALK, G. Bacterial metabolism (Springer series in microbiology). New York: Springer-Verlag, 1979.

GUILLARD, R.R.; RYTHER, J.H. Studies of marine planktonic diatoms. I. Cyclotella nana Hustedt, and Detonula confervacea (cleve) Gran. Canadian Journal of Microbiology, v.8., p. 229-239, 1962.

GÜTSCHOW, J. et al. The PRIMAP-hist national historical emissions time series v2.1 (18502017). GFZ Data Services, 2019.

HALLBERG, K.B; HEDRICH, S.; JOHNSON, D.B. Acidiferrobacter thiooxydans, gen. nov. sp. nov.; an acidophilic, thermo-tolerant, facultatively anaerobic iron- and sulfur-oxidizer of the family Ectothiorhodospiraceae. Extremophiles, v.15, p.271-279, 2011.

HANSON T.E.; ALBER, B.E.; TABITA, F.R. Phototrophic $\mathrm{CO}_{2}$ fixation: recent insights into ancient metabolisms. In: BURNAP, R.; VERMAAS, W. Functional genomics and evolution of photosynthetic systems. New York: Springer, 2012, cap. 9, p. 239-241.

HASZELDINE, R.S. Carbon capture and storage: how green can black be? Science, v. 325, n. 5948, p. 1647-1652, 2009.

HAUSFATHER, Z. Analysis: Why scientists think $100 \%$ of global warming is due to humans. Carbon Brief, 13 dez. 2017. Disponível em: <https://www.carbonbrief.org/analysis-whyscientists-think-100-of-global-warming-is-due-to-humans>. Acesso em: 03 abr. 2020. 
HAUSFATHER, Z.; DRAKE, H. F.; ABBOTT, T.; SCHMIDT, G. A. Evaluating the performance of past climate model projections. Geophysical Research Letters, v. 47, n. 1, p. $1-10,2019$.

HEBEDA, O. Emissões de gases fluorados causadores de efeito estufa: desenvolvimento e análise de cenários para o Brasil até 2050. 2017. 171 p. Tese (Mestrado em Planejamento Energético) - COPPE, Universidade Federal do Rio de Janeiro, Rio de Janeiro, 2017.

$\mathrm{HU}$, J.-J. et al. Optimization of electron donors to improve $\mathrm{CO}_{2}$ fixation efficiency by a nonphotosynthetic microbial community under aerobic condition using statistical experimental design. Bioresource Technology, v.101, p.7062-7067, 2010.

HÜGLER, M.; SIEVERT, S.M. Beyond the Calvin Cycle: autotrophic carbon fixation in the ocean. Annual Review of Marine Science, v. 3, p. 261-269, 2011.

IBP/GEE. Gás do pré-sal: oportunidades, desafios e perspectivas. IBP/GEE UFRJ, 2017. Disponível em <https://www.ibp.org.br/personalizado/uploads/2017/04/2017 TD_Gas do_Pre_Sal_Oportunidades_Desafios_e_Perspectivas-1.pdf>. Acesso em: 07 abr. 2020.

IEA/UNIDO. Technology Roadmap: Carbon Capture and Storage in Industrial Applications. OECD/International Energy Agency and United Nations Industrial Development Organization, 2011. Disponível em $<$ https://webstore.iea.org/download/direct/574>. Acesso em: 04 abr. 2020.

IPCC. Capture of $\mathrm{CO}_{2}$. In: __. IPCC Special Report on Carbon dioxide Capture and Storage, IPCC, 2018, cap. 3, p. 106-178.

IPCS. INCHEM: Sodium sulfide ICSC: 1047. IPCS/INCHEM, 2020. Disponível em< http://www.inchem.org/documents/icsc/icsc/eics1047.htm>. Acesso em: 11 abr. 2020.

JADJELOVIC, V. et al. Beyond oil degradation: enzymatic potential of Alcanivorax to degrade natural and synthetic polyesters. Environmental Microbiology, v.22, n. 4, p. 1356-1369, 2020.

JAJESNIAK, P.; ALI, H.E.M.O.; WONG, T.S. Carbon dioxide capture and utilization using biological systems: opportunities and challenges. Journal of Bioprocessing \& Biotechniques, v. 4, n. 3, p. 1-15, 2014.

JIN, X. et al. Potential microalgal strains for converting flue gas $\mathrm{CO}_{2}$ into biomass. Journal of Applied Phycology, 2020. DOI: 10.1007/s10811-020-02147-8

KALSCHEUER, R. et al. Analysis of storage lipid accumulation in Alcanivorax borkumensis: evidence for alternative triacylglycerol biosynthesis routes in bacteria. Journal of Bacteriology v.189, n. 3, p. 918-928, 2007.

KEGG. Sulfur metabolism - Alcanivorax borkumensis. KEGG, Kanehisa Laboratories. 2020. Disponível em<https://www.genome.jp/kegg-bin/show pathway?abo00920>. Acesso em: 03 de março de 2021.

KELLY D.P. Introduction to the Chemolithotrophic Bacteria. In: STARR M.P., STOLP H., TRÜPER H.G., BALOWS A., SCHLEGEL H.G. (eds) The Prokaryotes. Berlin, Heidelberg: Springer, 1981, cap. 79, p. 997-1004. 
KERSTERS, K. et al. Identification and typing of bacteria by protein electrophoresis. In: PRIEST et al., (eds). Bacterial Diversity and Systematics, New York: Plenum Press, 1994, p.51-66.

KIM, B.H.; GADD, G.M. Bacterial Physiology and Metabolism. New York, Cambridge University Press, 2008.

KOYTSOUMPA, E. I.; BERGINS, C.; KAKARAS, E. The $\mathrm{CO}_{2}$ economy: review of $\mathrm{CO}_{2}$ capture and reuse technologies. The Journal of Supercritical Fluids, v. 132, p. 3-16, 2018.

KUMAR, M.; GUPTA, A.; THAKUR, I.S. Carbon dioxide sequestration by chemolithotrophic oleaginous bacteria for production and optimization of polyhydroxyalkanoate. Bioresource Technology, v. 213, p. 249-256, 2016.

KUMAR, M. et al. Characterization of carbon dioxide concentrating chemolithotrophic bacterium Serratia sp. ISTD04 for production of biodiesel. Bioresource Technology, v. 243, p. 893-897, 2017.

KUMAR, M. et al. Carbon dioxide capture, storage and production of biofuel and biomaterials by bacteria: a review. Bioresource Technology, v. 247, p. 1059-1068, 2018.

KWON, H.-S. et al. Biofixation of high-concentration carbon dioxide using a deep-sea bacterium: Sulfurovum lithotrophicum 42BKTT. RSC Advances, v.5, p.7151-7159, 2015.

LAST, G.V.; SCHMICK, M.T. Identification and Selection of Major Carbon Dioxide Stream Compositions. Pacific Northwest National Laboratory, Richland, 2011.

LEESON, D. et al. A techno-economic analysis and systematic review of carbon capture and storage (CCS) applied to the iron and steel, cement, oil refining and pulp and paper industries, as well as other high purity sources. International Journal of Greenhouse and Gas Control, v.61, p.71-84, 2017.

LIU, S. et al. Growth and nutrient utilization of green algae in batch and semicontinuous autotrophic cultivation under high $\mathrm{CO}_{2}$ concentration. Applied Biochemistry and Biotecnology, 2019. DOI: 10.1007/s12010-018-02940-9.

LONGHI, D.A. et al. Microbial growth models: a general mathematical approach to obtain $\mu_{\max }$ and $\lambda$ parameters from sigmoidal empirical primary models. Brazilian Journal of Chemical Engineering, v.34, n. 2, p. 369-375, 2017.

LÓPEZ, C.V.G. et al. Utilization of the cyanobacteria Anabaena sp. ATCC 33047 in $\mathrm{CO}_{2}$ removal processes. Bioresource Technology, v.100, n.23, p. 5904-5910, 2009.

MAIA, J.L.P. Separação e captura do dióxido de carbono em instalações marítimas de produção de petróleo. 2007. 216 p. Tese (Doutorado em Engenharia Hidráulica e Sanitária) Escola Politécnica da Universidade de São Paulo, São Paulo, 2007.

MALL, A. et al. Reversibility of citrate synthase allows autotrophic growth of a thermophilic bacterium. Science, v. 359, p. 563-567, 2018. 
MANILLA-PÉREZ, E. et al. Neutral lipid production in Alcanivorax borkumensis SK2 and other marine hydrocarbonoclastic bactéria. European Journal of Lipid Science and Technology, v.113, p. 8-17, 2011

MARKEWITZ, P. et al. E. Worldwide innovations in the development of carbon capture technologies and the utilization of $\mathrm{CO}_{2}$. Energy \& Environmental Science, v.5, n. 6, p. 72817305.

MARRIOT, R.A. et al. Hydrogen sulfide formation in oil and gas. Canadian Journal of Chemistry, v.94, n.4, 2016.

MASUDA, S. et al. Thiossulfate-dependent chemolithoautotrophic growth of Bradyrhizobium japonicum. Applied and Environmental Microbiology, v.76, n. 8, p.2402-2409 2010.

MATASSA, S. et al. Autotrophic nitrogen assimilation and carbon capture for microbial protein production by a novel enrichment of hydrogen-oxidizing bacteria. Water Research, v. 101, p.137-146, 2016.

MINIC, Z.; THONGBAM, P.D. The biological deep-sea hydrothermal vent as a model to study carbon dioxide capturing enzymes. Marine Drugs, v.9, p. 719-738 2011

MISHRA, S. et al. $\mathrm{CO}_{2}$ sequestration potential of halo-tolerant bacterium Pseudomonas aeruginosa SSL-4 and its application for recovery of fatty alcohols. Process Safety and Environmental Protection, v. 111, p. 582-591, 2017 a.

MISHRA, S. et al. Application of novel thermo-tolerant haloalkalophilic bacterium Halomonas stevensii for bio mitigation of gaseous phase $\mathrm{CO}_{2}$ : energy assessment and product evaluation studies. Process Biochemistry, v. 55, p.133-145, $2017 \mathrm{~b}$.

MISTRY, A. N. et al. Sequestration of $\mathrm{CO}_{2}$ using microorganisms and evaluation of their potential to synthesize biomolecules. Separation Science and Technology, p. 1-14, 2019.

MIYAHARA, M. et al. Potential of aerobic denitrification by Pseudomonas stutzeri TR2 to reduce nitrous oxide emissions from wastewater treatment plants. Applied and Environmental Microbiology, v. 76, n. 14, p. 4619-4625, 2010.

MIYAHARA, Y.; YAMAMOTO, W.; THORBECKE, R.; MIZUNO, S.; TSUGE, T. Autotrophic biosynthesis of polyhydroxyalkanoate by Ralstonia eutropha from noncombustible gas mixture with low hydrogen content. Biotechnology Letters, 2020.

MOGHIMIFAM, R. et al. The influence of different $\mathrm{CO}_{2}$ concentrations on the biochemical and molecular response of two isolates of Dunaliella sp. (ABRIINW-CH2 and ABRIINWSH33). Journal of Applied Phycology, 2019. DOI: 10.1007/s10811-019-01914-6.

MORAIS, J.M. de. Petróleo em águas profundas: uma história tecnológica da PETROBRÁS na exploração e produção offshore. IPEA: PETROBRÁS, Brasília, 2013.

MOREIRA, J.B. et al. Utilization of $\mathrm{CO}_{2}$ in semi-continuous cultivation of Spirulina sp. And Chlorella fusca and evaluation of biomass composition. Brazilian Journal of Chemical Engineering, v. 33, n. 3, p. 691-698, 2016. 
MORENO, J. et al. Exopolysaccharide production by the cyanobacterium Anabaena sp. ATCC 33047 in batch and continuous culture. Journal of Biotechnology, v. 60, p. 175-182, 1998.

MORICE, C.P.; KENNEDY, J.J.; RAYNER, N.A.; JONES, P.D. Quantifying uncertainties in global and regional temperature change using an ensemble of observational estimates: the HadCRUT4 dataset. Journal of Geophysical Research, v.117, n. D08101, 2012.

MUHAMMAD, M.H. et al. Beyond risk: bacterial biofilms and their regulating approaches. Frontiers in Microbiology, v. 11, n. 928, 2020.

MULA, A. et al. Diversity of culturable nitrate-reducing bacteria from the Arabian Sea oxygen minimum zone. Deep Sea Research Part II: Topical Studies in Oceanography, v.156, p.2733, 2018.

NASCIMENTO, J.T. do. Avaliação técnico-econômica de ultracentrífugas a gás para remoção de $\mathrm{CO}_{2}$ em plataformas do Pré-Sal. 2012. $124 \mathrm{f}$. Tese (Mestrado em Tecnologia de Processos Químicos e Bioquímicos) - Universidade Federal do Rio de Janeiro, Escola de Química, Rio de Janeiro, 2012.

NCBI. PubChem: sodium thiosulfate. NCBI/NLM, 2020. Disponível em $<$ https://pubchemncbi.nlm. nih.gov/compound/24477\#datasheet=LCSS $>$. Acesso em: 05 jun. 2020.

NGUYEN, T.H. et al. Physiological characterization of poly- $\beta$-hydroxybutyrate accumulation in the moderately thermophilic hydrogen-oxidizing bacterium Hydrogenophilus thermoluteolus TH-1. Journal of Bioscience and Bioengineering, v. 127, n.6, p. 686-689, 2019.

NOAA/ESRL. Trends in atmospheric carbon dioxide. US Department of Commerce: National Oceanic \& Atmospheric Administration. 2021. Disponível em< https://www.esrl.noaa.gov/gmd/ccgg/trends/global.html>. Acesso em: 02 mar. 2021

NUNOURA, T. et al. A primordial and reversible TCA cycle in a facultatively chemolithoautotrophic thermophile. Science, v. 359, p. 559-563, 2018.

NYQUIST, S.; RUYS, J. CO2 abatement: Exploring options for oil and natural gas companies. McKinsey \& Company: Oil \& Gas, 2010. Disponível em<>. Acesso em: 04 abr. 2020.

OKPALA, G.N. et al. Effect of Thermophilic Nitrate Reduction on Sulfide Production in High Temperature Oil Reservoir Samples. Frontiers in Microbiology, v.8, n.1573, 2017. doi: 10.3389/fmicb.2017.01573

OLIVIER; J.G.J.; PETERS, J.A.H. Trends in global $\mathrm{CO}_{2}$ and total greenhouse-gas emissions: Summary of the 2019 Report. PBL Netherlands Environmental Assessment Agency, Haia, 04 dez. 2019. Disponível em<https:/www.pbl.nl/sites/default/files/downloads/pbl-2019trends-in-global-co2-and-total-greenhouse-gas-emissions-summary-ot-the-2019report 4004.pdf > . Acesso em: 03 abr. 2020.

OMAROVA M. et al. Biofilm formation by hydrocarbon-degrading marine bacteria and its effects on oil dispersion. ACS Sustainable Chemistry \& Engineering, 2019. doi:10.1021/acssuschemeng.9b01923 
PARK, S. et al. Kinetics of $\mathrm{CO}_{2}$ fixation by Sulfurovum lithotrophicum $42 \mathrm{BKT}^{\mathrm{T}}$ : medium optimization and tolerance of $\mathrm{CO}_{2}$ toxicity. Journal of Environmental Chemical Engineering, v.8, n.6, 2020.

PEREIRA, N.J.; BON, E.P.S.; FERRARA, M.A. Tecnologia em bioprocessos. Rio de Janeiro: Escola de Química/UFRJ, 2008. v.1 (Séries em Biotecnologia).

POURJAMSHIDIAN, R. et al. Carbon dioxide biofixation by Chlorella sp. In a bubble column reactor at different flow rates and $\mathrm{CO}_{2}$ concentrations. Brazilian Journal of Chemical Engineering, v.36, n.2, p.639-645, 2019.

RAHUL, K. et al. Alcanivorax xenomutans sp. nov., a hydrocarbonoclastic bacterium isolated from a shrimp cultivation pond. International Journal of Systematic and Evolutionary Microbiology, v. 64, p. 3553-3558, 2014.

RAJA, H.A. et al. Fungal identification using molecular tools: a primer for the natural products research community. Journal of Natural Products, v. 80, n. 3, p. 756-770, 2017.

RAS. M; STEYER, J-.P.; BERNARD, O. Temperature effect on microalgae: a crucial factor for outdoor production. Reviews in Environmental Science and Bio/Technology, v. 12, p. 153-164, 2013.

REITER, G.; LINDORFER, J. Evaluating CO2 sources for power-to-gas applications - A case study for Austria. Journal of $\mathbf{C O}_{2}$ Utilization, v. 10, p. 40-49, 2015.

RHODE, R. Global temperature report for 2020. Berkeley Earth, 2021. Disponível em< http://berkeleyearth.org/global-temperature-report-for-2020/>. Acesso em: 15 mar. 2021.

RITCHIE, H.; ROSER, M. $\mathrm{CO}_{2}$ and Greenhouse Gas Emissions. OurWorldInData, 2019. Disponível em $<$ https://ourworldindata.org/co2-and-other-greenhouse-gas-emissions $>$. Acesso em: 04 abr. 2020.

ROMANO, M.C et al. Application of advanced technologies for $\mathrm{CO}_{2}$ capture from industrial sources. Energy Procedia, v. 37, p. 7176-7185, 2013.

SAINI, R.; KAPOOR, R.; KUMAR, R.; SIDDIQI, T.O.; KUMAR, A. $\mathrm{CO}_{2}$ utilizing microbes: a comprehensive review. Biotechnology Advances, v.29, p. 949-960, 2011.

SALEHIZADEH, H.; YAN, N.; FARNOOD, R. Recent advances in microbial $\mathrm{CO}_{2}$ fixation and conversion to value-added products. Chemical Engineering Journal, 2020. DOI: https://doi.org/10.1016/j.cej.2020.124584

SAMAD, R.A. et al. The use of principle component analysis and MALDI-TOF MS for the differentiation of mineral forming Virgibacillus and Bacillus species isolated from sabkhas. RSC Advances, v.10, p. 14606-14616, 2020.

SAYARI, A.; BELMABKHOUT, Y.; GUERRERO, R.S-. Flue gas treatment via CO2 adsorption. Chemical Engineering Journal, v. 171, p. 760 - 774, 2011. 
SCOMA, A. et al. Microbial oil-degradation under mild hydrostatic pressure (10MPa): which pathways are impacted in piezosensitive hydrocarbonoclastic bacteria? Scientific Reports, v. 6, n.23526, 2016.

SEEG. Novas estimativas do SEEG Brasil - 2018. SEEG Brasil, 06 nov. 2019. Disponível em< http://plataforma.seeg.eco.br/total_emission\#>. Acesso em: 03 abr. 2020.

SEEG. Emissões dos setores de energia, processos industriais e uso de produtos - Documento de Análise 2018. SEEG Brasil, 2018.

SHARMA, A. et al. Microbial biofilm: an advanced eco-friendly approach for bioremediation. In:__. GUPTA, V. (ed) New and future developments in microbial biotechnology and bioengineering. Elsevier, 1a ed., cap. 15, p. 205-219, 2016.

SHIMEKIT, B.; MUKHTAR, H. Natural gas purification technologies - major advances for $\mathrm{CO}_{2}$ separation and future directions. Advances in Natural Gas Technology, p.235-270, 2012.

SILVEIRA, C.B; THOMPSON, F. The Family Alcanivoraceae. In: ROSENBERG R., DELONG E.F., LORY S., STACKEBRANDT E., THOMPSON F. (eds) The Prokaryotes: Gammaproteobacteria. Berlin, Heidelberg: Springer, 4ª ed., cap. 4, p. 59-6, 2014.

SONGOLZADEH, M.; SOLEIMANI, M.; RAVANCHI, M.T.; SONGOLZADEH, R. Carbon dioxide separation from flue gases: a technological review emphasizing reduction in greenhouse gas emissions. The Scientific World Journal, v. 2014, p. 1-34, 2014.

STEVENSON, K.; MCVEY, A.F.; CLARK, I.B.N.; SWAIN, P.S.; PILIZOTA, T. General calibration of microbial growth in microplate readers. Scientific Report, v.6, n.38828, 2016.

STEWART, C.; HASSAMI, M. A study on methods of carbon dioxide capture and sequestration - the sustainability of a photosynthetic bioreactor approach. Energy Conversion and Management, v. 46, n.3, p. 403-420, 2005.

STROHALM, M. mMass. Disponível em<http://www.mmass.org>. Acesso em: 02 abr. 2020.

STYRING, P. et al. Carbon capture and utilisation in the green economy. The Centre for Low Carbon Futures and CO2Chem Publishing, 2011. Disponível em $<$ http://co2chem.co.uk/wpcontent/uploads/2012/06/CCU\%20in $\% 20$ the $\% 20$ green $\% 20$ economy $\% 20$ report.pdf $>$. Acesso em: 11 abr. 2020.

THAKUR, I.S. et al. Sequestration and utilization of carbon dioxide by chemical and biological methods for biofuels and biomaterials by chemoautotrophs: opportunities and challenges. Bioresource Technology, v. 256, p. 478-490, 2018.

VAN DEDEM, G.; MOO-YOUNG, M. A model for diauxic growth. Biotechnology and Bioengineering, v.17, n. 9, p. 1301-1312, 1975.

XIAO, M. et al. Analysis of bacterial diversity in two oil blocks from two low-permeability reservoirs with high salinities. Scientific reports, v. 6, n. 19600, 2016.

ZHANG, X. Microalgae removal of $\mathbf{C O}_{2}$ from flue gas. London: IEA Clean Coal Centre, 2015. 
ZHOU, W. et al. Bio-mitigation of carbon dioxide using microalgal systems: Advances and perspectives. Renewable and Sustainable Energy Reviews, v. 76, p. 1163-1175, 2017.

ZHU, Y. et al. Sensitive and fast identification of bacteria in blood samples by immunoaffinity mass spectrometry for quick BSI diagnosis. Chemical Science, v.7, p. 2987-2995.

ZWIETERING, M.H. et al. Modeling of the bacterial growth curve. Applied and Environmental Microbiology, v.56, n. 6, p. 1875-1881, 1990.

ZYMO. Instruction manual: Quick-DNA ${ }^{\mathrm{TM}}$ Fungal/Bacterial Miniprep Kit Catalog No. D6005. Zymo Research Corporation. 2021. Disponível em< https://files.zymoresearch.com/protocols/_d6005 quick-dna_fungal-bacterial_miniprep_kit.

pdf $>$ Acesso em: 20 de fevereiro de 2021.

WAGENMAKERS, E-.J.; FARRELL, S. AIC model selection using Akaike weights. Psychonomic Bulletin \& Review, v. 11, n. 1, p. 192-196, 2004.

WANG, B.; LI, Y.; WU, N.; LAN, C. Q. $\mathrm{CO}_{2}$ bio-mitigation using microalgae. Applied Microbiology and Biotechnology, v. 79, n.5, p. 707-718, 2008.

WATANABE, Y.; OHMURA, N.; SAIKI, H. Isolation and determination of cultural characteristics of microalgae, which functions under $\mathrm{CO}_{2}$ enriched atmosphere. Energy Conversion and Management, v. 33, p. 545-552, 1992.

WILKINS, D. Key microbial drivers in Antarctic aquatic environments. FEMS Microbiology Reviews, v.37, p. 303-335, 2013.

YAKIMOV, M.M. et al. Alcanivorax borkumensis gen. nov., sp. nov., a new, hydrocarbondegrading and surfactant- producing marine bacterium. International Journal of Systematic Bacteriology, v. 48, n. 2, p. 339-348, 1998.

YAKIMOV, M.M.; CAPELLO, S. Alcanivorax. In:_TIMMIS, K.N (ed.), Handbook of Hydrocarbon and Lipid Microbiology, Berlin, Heidelberg: Springer-Verlag, cap. 6, p. 59-6, 2010.

YANG, H. et al. Progress in carbon dioxide separation and capture: a review. Journal of Environmental Sciences, v.20, n.1, p.14-27, 2008.

YANIK, J. et al. Pyrolysis of algal biomass. Journal of Analytical and Applied Pyrolysis, v.103, p.134-141, 2013

YEN, H.-W. et al. $\mathrm{CO}_{2}, \mathrm{NO}_{\mathrm{x}}$ and $\mathrm{SO}_{\mathrm{x}}$ removal from flue gas via microalgae cultivation: a critical review. Biotechnology Journal, v. 10, n. 6, p. 829-839, 2015.

YOUNG, J.B.; JUNG, L.; PARK, D.H. Enrichment of $\mathrm{CO}_{2}$-fixing bacteria in cylinder-type electrochemical bioreactor with built-in anode compartment. Journal of Microbiology and Biotechnology, v.21, n.6, p.590-598, 2011.

YU, C-.H; HUANG, C-.H; TAN, C-. S. A review of $\mathrm{CO}_{2}$ capture by absorption and adsorption. Aerosol and Air Quality Research, v. 12, p. 745-769, 2012. 
YU, J. Fixation of carbon dioxide by a hydrogen-oxidizing bacterium for value-added products. World Journal of Microbiology and Biotechnology, v.34, n.89, 2018.

YU, J.; LU, Y. Carbon dioxide fixation by a hydrogen-oxidizing bacterium: Biomass yield, reversal respiratory quotient, stoichiometric equations and bioenergetics. Biochemical Engineering Journal, v.152, n. 107369, 2019.

YU, J.; MUNASINGHE, P. Gas fermentation enhancement for chemolithotrophic growth of Cupriavidus necator on carbon dioxide. Fermentation, v. 4, n. 63, p.1-14, 2018

YUE, L.; CHEN,W. Isolation and determination of cultural characteristics of a new highly $\mathrm{CO}_{2}$ tolerant fresh water microalgae. Energy Conversion and Management, v. 46, p.1868$1876,2005$. 
APÊNDICE A - Curvas de calibração de massa seca e resultados de TOC

Figura 34 - Regressão linear da curva de massa seca (X, g/L) em função da densidade ótica (DO) para a cepa M1B-S.

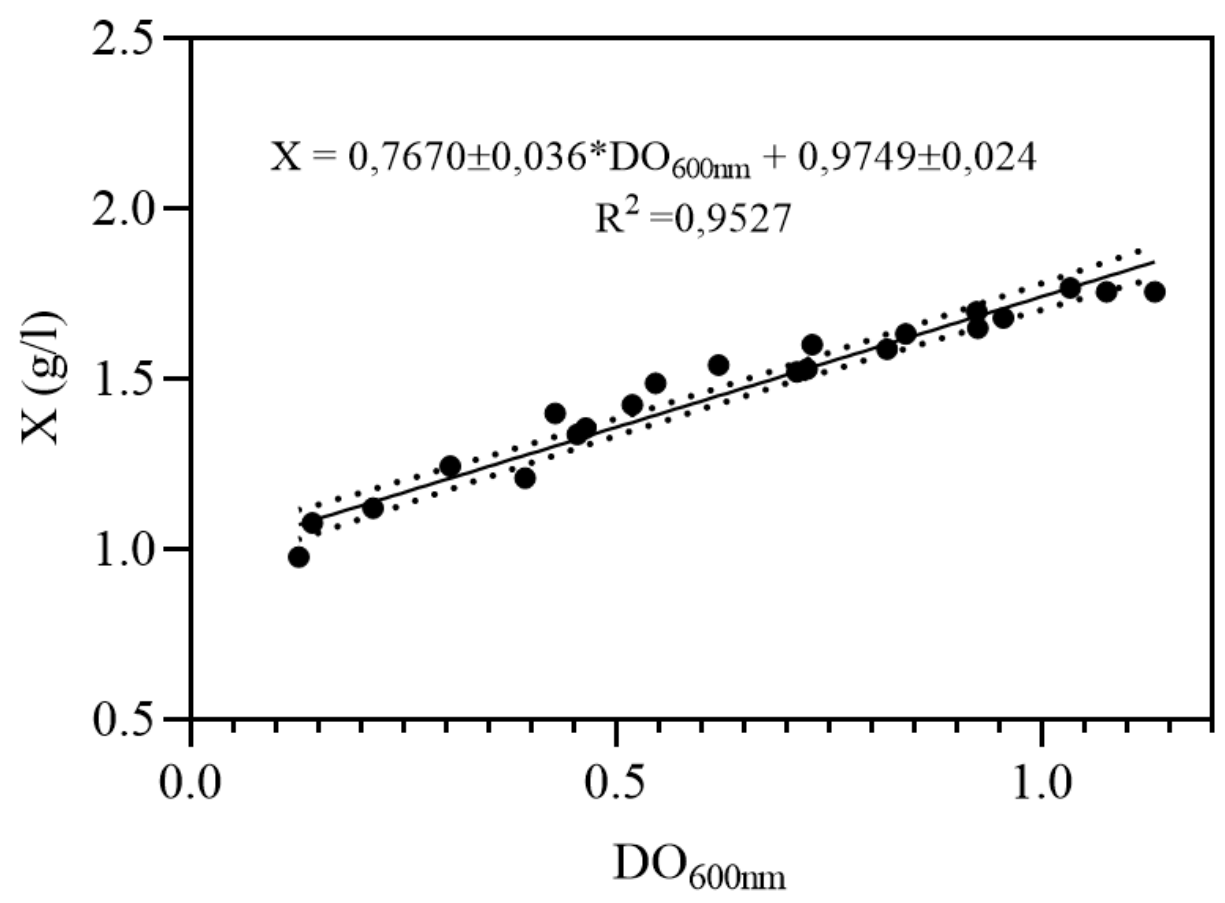

Tabela 16 - Resultados da análise de carbono orgânico total (TOC) do meio de cultura ( $\mathrm{TOC}_{\mathrm{mc}}$ ) e das suspensões bacterianas $\left(\mathrm{TOC}_{\mathrm{sb}}\right)$.

\begin{tabular}{|c|c|c|c|c|}
\hline Amostra & $\mathbf{X}_{\mathbf{s b}}(\mathrm{g} / \mathrm{L})$ & $\begin{array}{c}\text { TOC }_{\text {sb }} \\
\text { (g de C/L) }\end{array}$ & $\begin{array}{c}\text { TOC }_{m c} \\
(\mathrm{~g} \mathrm{de} \mathrm{C/L)}\end{array}$ & $\begin{array}{l}\text { Teor de carbono na biomassa } \\
\left(\mathbf{C}_{\mathrm{sb}}, \%\right)\end{array}$ \\
\hline 1 & 0,08510 & 0,0418 & 0,7269 & $49,12 \%$ \\
\hline 2 & 0,1015 & 0,0495 & 0,7978 & $48,74 \%$ \\
\hline 3 & 0,1282 & 0,05760 & 0,1514 & $44,92 \%$ \\
\hline \multicolumn{3}{|c|}{ Média \pm SD } & $0,7800 \pm 0,04359$ & $47,59 \% \pm 2 \%$ \\
\hline
\end{tabular}


APÊNDICE B - Espectros de massa e perfis eletroforéticos das cepas isoladas a partir dos meios de cultura ASM, SM E MM

Figura 35 - Espectros de massa e perfis eletroforéticos das proteínas extraídas das bactérias do meio ASM. a) as cepas AS3B, ASB2A, ASB2B e ASB4B apresentam perfis eletroforéticos semelhantes, e foram agrupadas em espécies similares ou iguais. b) ASB4A e AS3D foram agrupadas em espécies semelhantes. c) A análise resultou em cinco cepas com espectros distintos: AS3A, AS3B, AS3C, ASA1B e AS3D.

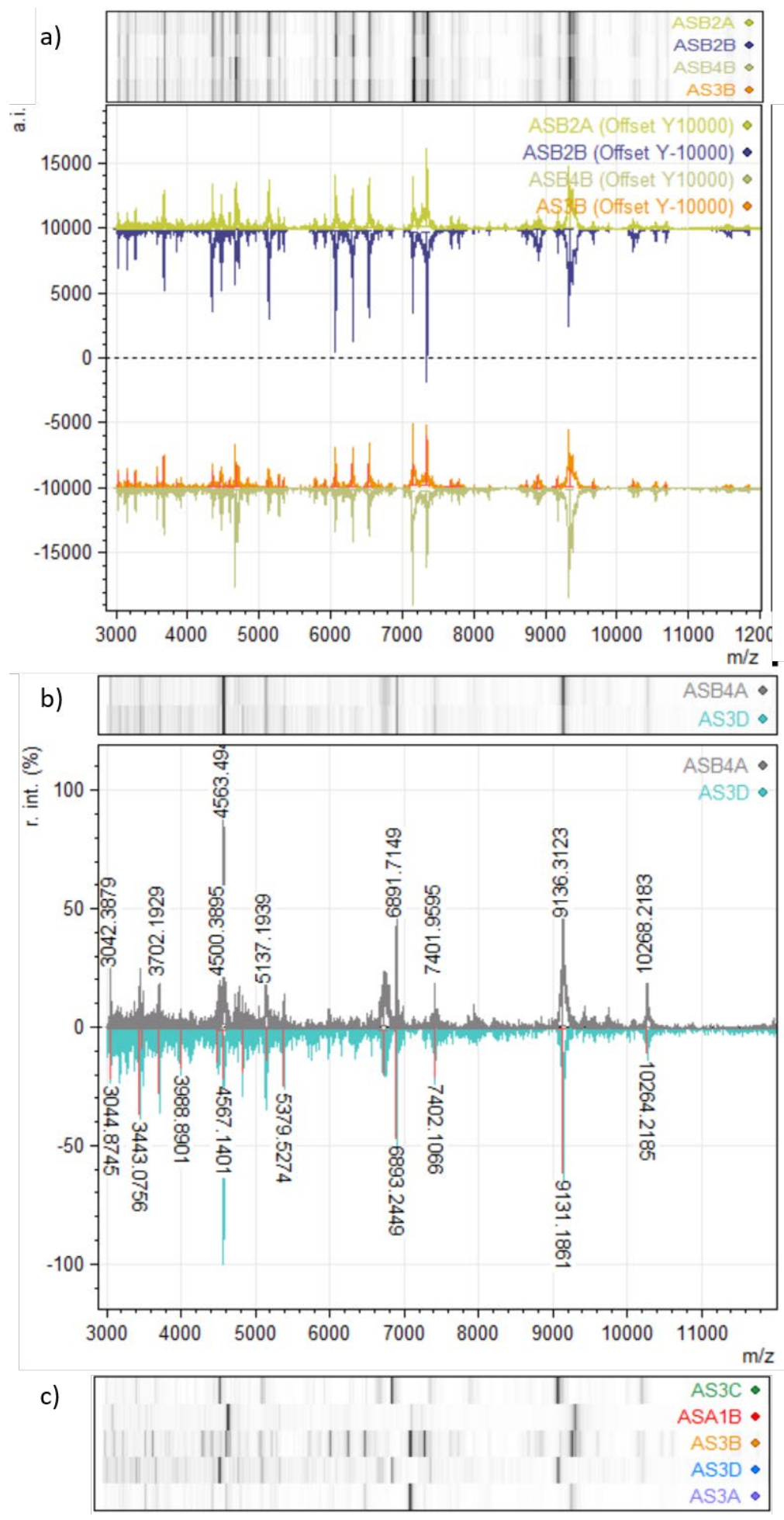


Figura 36 - Comparação entre as listas de picos obtidos para os espectros das cepas AS3C (verde), AS3B (laranja), AS3A (roxo), AS3D (azul) e ASA1B (vermelho). Os picos foram selecionados e comparados através do software mMass. Os quadrados coloridos e sem asterisco representam picos iguais em mais de um espectro. Quadrados coloridos e com asterisco indicam que a lista de picos apresentada corresponde à cepa referente à coloração do quadrado.

\begin{tabular}{|c|c|c|c|c|c|c|c|c|c|c|c|c|c|c|c|c|c|c|c|c|c|c|c|c|c|c|c|c|c|}
\hline \multicolumn{7}{|c|}{ Picos AS3C } & \multicolumn{6}{|c|}{ Picos ASA1B } & \multicolumn{6}{|c|}{ Picos AS3B } & \multicolumn{6}{|c|}{ Picos AS3D } & \multicolumn{5}{|c|}{ Picos AS3A } \\
\hline $\mathrm{m} / \mathrm{z}$ & $\approx$ & $*$ & $*$ & $*$ & 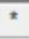 & $\mathrm{m} / \mathrm{z}$ & $*$ & $*$ & $\star$ & $*$ & $*$ & $\mathrm{~m} / \mathrm{z}$ & $=$ & $*$ & $\approx$ & $*$ & $*$ & $\mathrm{~m} / \mathrm{z}$ & $*$ & $\star$ & $*$ & 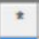 & $*$ & $\mathrm{~m} / \mathrm{z}$ & $=$ & $*$ & \pm & $*$ & $\approx$ \\
\hline 3040.0673 & 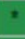 & & & & & 3024.8411 & & $*$ & & & & 3024.7420 & & & $*$ & & & 3044.8745 & & & & $=$ & & 3258.8539 & & & & & $*$ \\
\hline 3444.5747 & * & & & & & 3108.5823 & & * & & & & 3145.1688 & & & $*$ & & & 3443.0756 & & & & $*$ & & 3566.3925 & & & & & $*$ \\
\hline 3701.7275 & * & & & & & 3115.5497 & & * & & & & 3258.3167 & & & * & & & 3483.2863 & & & & $*$ & & 3720.0932 & & & & & $=$ \\
\hline 4563.3148 & $\approx$ & & & & & 3129.1480 & & $*$ & & & & 3566.1529 & & & $*$ & & & 3700.2331 & & & & $=$ & & 4467.5770 & & & & & $\cdot$ \\
\hline 5130.9836 & $\therefore$ & & & & & 3139.0766 & & $*$ & & & & 3663.3135 & & & $*$ & & & 3988.8901 & & & & 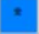 & & 4655.3835 & & & & & $=$ \\
\hline 5161.1213 & 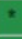 & & & & & 3369.0900 & & $*$ & & & & 3835.9486 & & & $*$ & & & 4490.7577 & & & & $\cdot$ & & 4678.9833 & & & & & $*$ \\
\hline 5978.9642 & $\div$ & & & & & 3573.7486 & & $*$ & & & & 4336.8531 & & & $*$ & & & 4567.1401 & & & & 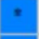 & & 4845.0930 & & & & & $*$ \\
\hline 6546.5822 & 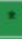 & & & & & 3581.6118 & & $*$ & & & & 4458.5050 & & & $*$ & & & 4816.9808 & & & & $\cdot$ & & 6521.4157 & & & & & $*$ \\
\hline 6890.6431 & \pm & & & & & 3642.8152 & & $*$ & & & & 4579.2010 & & & $*$ & & & 5140.7112 & & & & 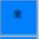 & & 7134.8787 & & & & & $*$ \\
\hline 7401.5678 & 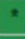 & & & & & 3646.5439 & & $*$ & & & & 4678.7601 & & & $*$ & & & 5379.5274 & & & & 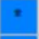 & & 7329.1747 & & & & & $=$ \\
\hline 9122.6383 & \pm & & & & & 4369.5397 & & $*$ & & & & 5114.4174 & & & * & & & 6725.0316 & & & & * & & 9309.6524 & & & & & $=$ \\
\hline 10262.1734 & $*$ & & & & & 4681.9243 & & $*$ & & & & 5264.5679 & & & $*$ & & & 6893.2449 & & & & $=$ & & 9355.3721 & & & & & $*$ \\
\hline & & & & & & 5378.3679 & & $*$ & & & & 5336.7115 & & & * & & & 7402.1066 & & & & 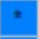 & & & & & & & \\
\hline & & & & & & 6061.1549 & & $*$ & & & & 5778.8639 & & & $*$ & & & 9131.1861 & & & & 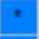 & & & & & & & \\
\hline & & & & & & 7153.3352 & & $*$ & & & & 5911.8214 & & & * & & & 10264.2185 & & & & * & & & & & & & \\
\hline & & & & & & 7296.6445 & & * & & & & 6051.3872 & & & $*$ & & & & & & & & & & & & & & \\
\hline & & & & & & 9362.1389 & & $*$ & & & & 6294.3269 & & & $*$ & & & & & & & & & & & & & & \\
\hline & & & & & & & & & & & & 6527.2878 & & & $*$ & & & & & & & & & & & & & & \\
\hline & & & & & & & & & & & & 7143.7527 & & & $*$ & & & & & & & & & & & & & & \\
\hline & & & & & & & & & & & & 7331.6795 & & & $*$ & & & & & & & $C$ & 8 & & & & & & \\
\hline & & & & & & & & & & & & 7677.9667 & & & $*$ & & & & & & & & 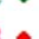 & & & & & & \\
\hline & & & & & & & & & & & & 7780.9494 & & & $*$ & & & & & & & & 8 & & & & & & \\
\hline & & & & & & & & & & & & 8735.1555 & & & $*$ & & & & & & & 3日 & 8 & & & & & & \\
\hline & & & & & & & & & & & & 8892.1234 & & & $*$ & & & & & & AS & 3D & $\bullet$ & & & & & & \\
\hline & & & & & & & & & & & & 9160.4215 & & & $*$ & & & & & & AS & $3 \mathrm{~A}$ & $\bullet$ & & & & & & \\
\hline & & & & & & & & & & & & 9349.1626 & & & $*$ & & & & & & & & & & & & & & \\
\hline & & & & & & & & & & & & 9656.3241 & & & $*$ & & & & & & & & & & & & & & \\
\hline & & & & & & & & & & & & 10214.3763 & & & $*$ & & & & & & & & & & & & & & \\
\hline & & & & & & & & & & & & 10675.5085 & & & $*$ & & & & & & & & & & & & & & \\
\hline
\end{tabular}


Figura 37 - Comparação entre as listas de picos obtidos para os espectros das cepas AM2A, AM2B e AM2C. Os quadrados coloridos e sem asterisco representam picos iguais em mais de um espectro. Quadrados coloridos e com asterisco indicam que a lista de picos apresentada corresponde à cepa referente à coloração do quadrado.

\begin{tabular}{|c|c|c|c|c|c|c|c|c|c|c|c|}
\hline \multicolumn{4}{|c|}{ Picos AM2A } & \multicolumn{4}{|c|}{ Picos AM2C } & \multicolumn{4}{|c|}{ Picos AM2B } \\
\hline $\mathrm{m} / \mathrm{z}$ & $*$ & $*$ & $*$ & $\mathrm{~m} / \mathrm{z}$ & $*$ & $*$ & $*$ & $\mathrm{~m} / \mathrm{z}$ & $*$ & $*$ & * \\
\hline 3025.8937 & $*$ & & & 3092.2099 & & $*$ & & 3075.0596 & & & $*$ \\
\hline 3145.4144 & $*$ & & & 3152.1253 & & $*$ & & 3443.0468 & & & $*$ \\
\hline 3258.6876 & * & & & 3399.7981 & & $*$ & & 3700.6379 & & & $*$ \\
\hline 3566.6927 & $*$ & & & 3701.1836 & & $*$ & & 3920.4172 & & & $*$ \\
\hline 3666.0248 & $*$ & & & 4311.7691 & & $*$ & & 4490.1148 & & & * \\
\hline 4348.6897 & $*$ & & & 4644.7060 & & $*$ & & 4568.2266 & & & z \\
\hline 4460.7492 & $*$ & & & 4819.5110 & & $*$ & & 4774.3841 & & & $*$ \\
\hline 4681.1925 & $*$ & & & 5163.9472 & & $*$ & & 5134.4036 & & & $*$ \\
\hline 5125.3258 & $*$ & & & 5380.5799 & & $*$ & & 6326.3100 & & & $*$ \\
\hline 5266.0095 & $*$ & & & 5872.6875 & & $*$ & & 6545.7034 & & & $*$ \\
\hline 5338.7329 & $*$ & & & 6307.5543 & & $*$ & & 6730.5612 & & & * \\
\hline 6060.6613 & $*$ & & & 6805.7655 & & 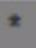 & & 6892.7143 & & & $*$ \\
\hline 6296.1355 & * & & & 7406.1044 & & $\approx$ & & 7410.2675 & & & $*$ \\
\hline 6538.7186 & $*$ & & & 7596.3995 & & $*$ & & 9136.8377 & & & * \\
\hline 7145.8721 & * & & & 9294.5475 & & $*$ & & 10268.5495 & & & * \\
\hline 7338.6955 & $*$ & & & 10318.6231 & & $*$ & & AM2A $\bullet$ & & & \\
\hline 8880.7402 & $*$ & & & 12627.3789 & & $*$ & & $\mathrm{AM} 2 \mathrm{C} \bullet$ & & & \\
\hline 9352.4983 & * & & & & & & & & & & \\
\hline
\end{tabular}


Figura 38 - Espectros peptídicos normalizados e perfis eletroforéticos das quatro cepas isoladas a partir do meio SM. Todas as cepas apresentaram perfis distintos e foram consideradas diferentes.

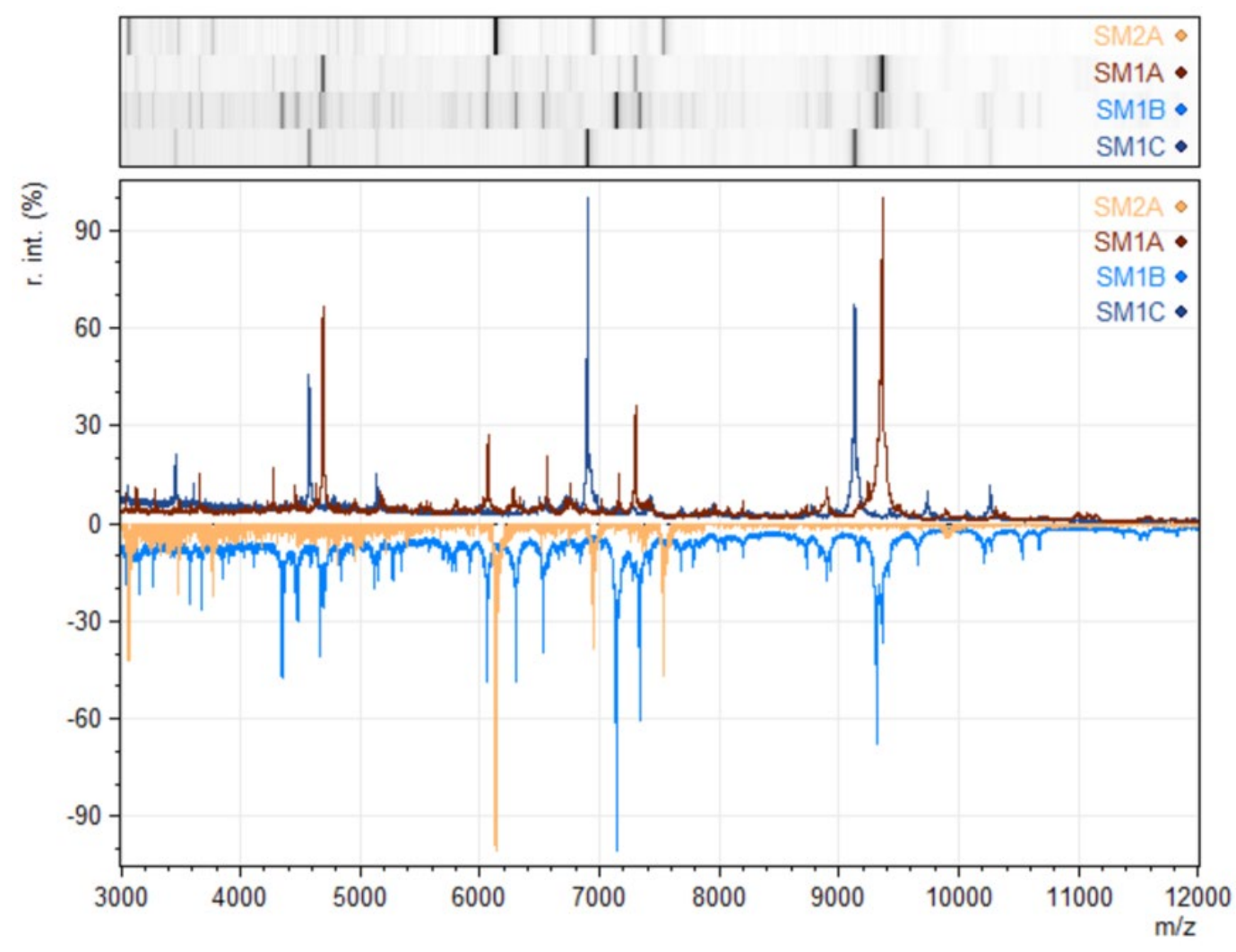


Figura 39 - Comparação entre as listas de picos obtidos para os espectros das cepas SM1A, SM1B, SM1C e SM2A Os quadrados coloridos e sem asterisco representam picos iguais em mais de um espectro. Quadrados coloridos e com asterisco indicam que a lista de picos apresentada corresponde à cepa referente à coloração do quadrado.

\section{Picos SM1A}

Picos SM1B

Picos SM1C

Picos SM2A

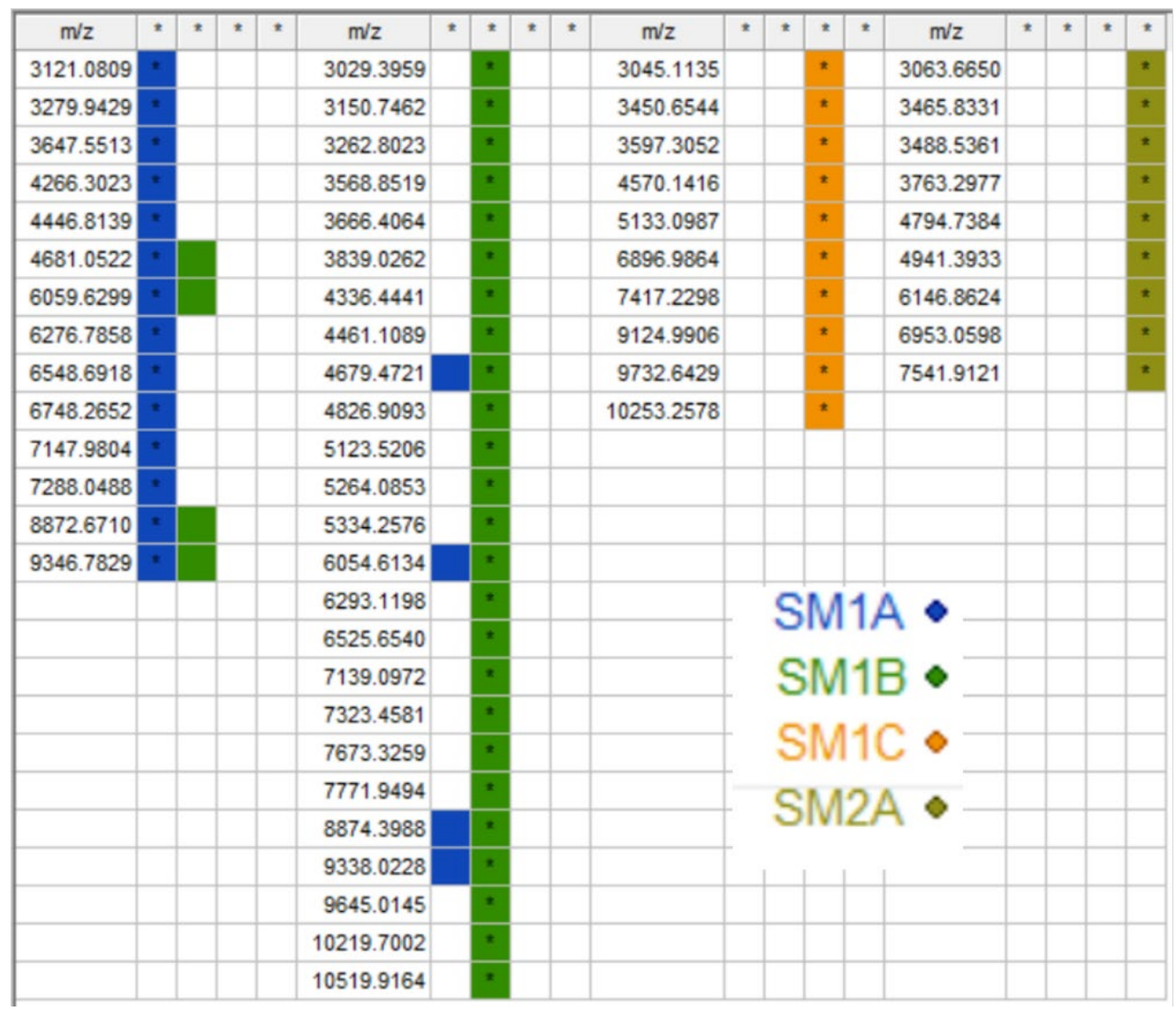


Figura 40 - Espectros de massa normalizados e perfis eletroforéticos das proteínas extraídas a partir das três cepas isoladas do meio de cultura MM. Todas as cepas apresentaram perfis distintos e foram consideradas diferentes.

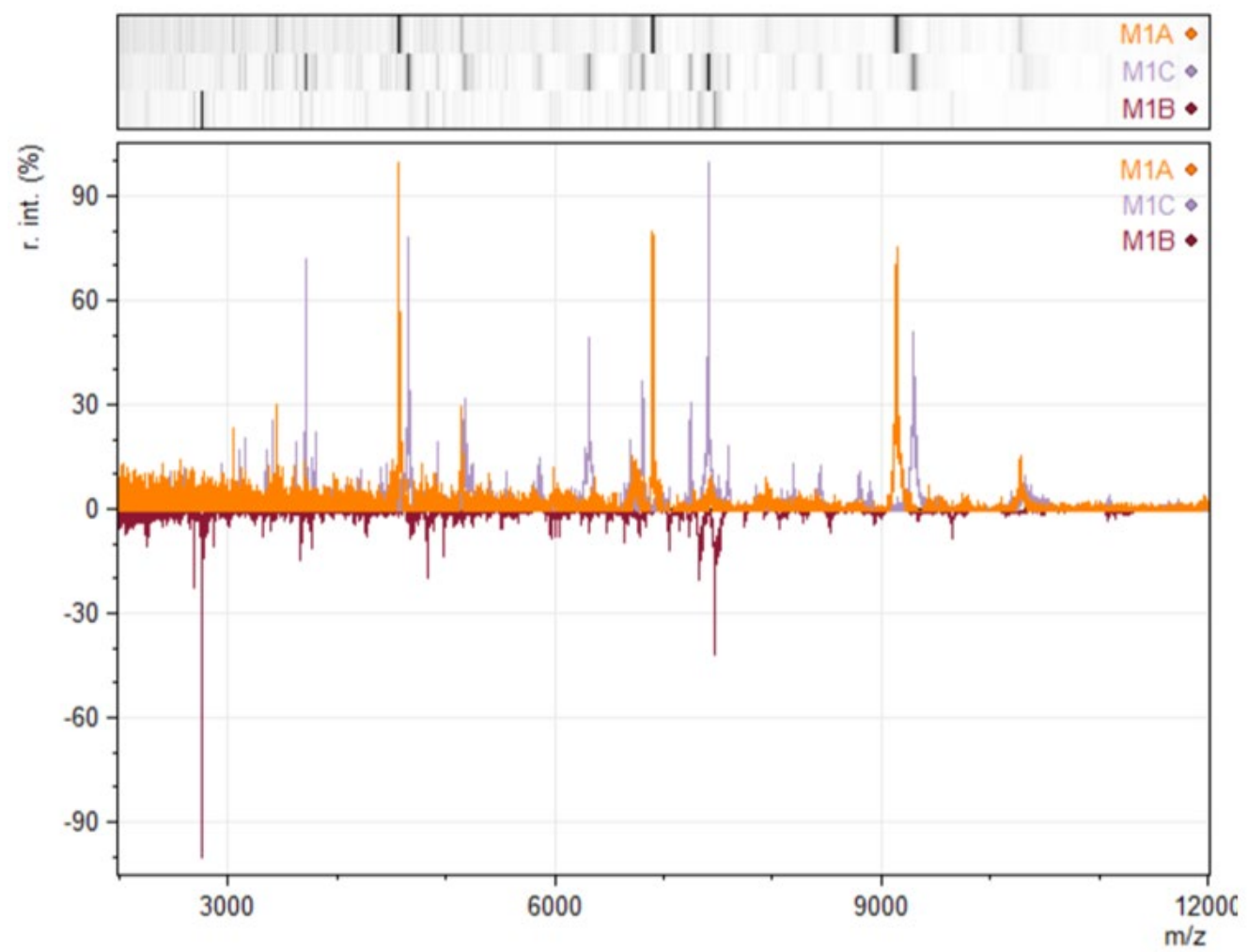


Figura 41 - Comparação entre as listas de picos obtidos para os espectros das cepas M1A, M1B e M1C. Os quadrados coloridos e sem asterisco representam picos iguais em mais de um espectro. Quadrados coloridos e com asterisco indicam que a lista de picos apresentada corresponde à cepa referente à coloração do quadrado.

\section{Picos M1A}

Picos M1B

Picos M1C

\begin{tabular}{|c|c|c|c|c|c|c|c|c|c|c|c|}
\hline $\mathrm{m} / \mathrm{z}$ & * & * & * & $\mathrm{m} / \mathrm{z}$ & * & * & * & $\mathrm{m} / \mathrm{z}$ & * & * & $*$ \\
\hline 2398.2606 & 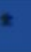 & & & 2255.6096 & & * & & 2937.8964 & & & * \\
\hline 2561.0621 & * & & & 2679.3800 & & $*$ & & 3153.5783 & & & $*$ \\
\hline 3039.9417 & $*$ & & & 2750.5261 & & * & & 3332.0026 & & & * \\
\hline 3372.1645 & * & & & 2861.5182 & & * & & 3403.6503 & & & * \\
\hline 3441.6961 & * & & & 3668.4496 & & * & & 3621.4812 & & & * \\
\hline 3593.9021 & * & & & 4824.0621 & & * & & 3708.6585 & & & * \\
\hline 3698.3921 & * & & & 4976.4247 & & * & & 3797.3762 & & & * \\
\hline 4572.8689 & * & & & 5957.8991 & & * & & 4216.1819 & & & * \\
\hline 4765.9010 & * & & & 6629.8236 & & * & & 4649.9947 & & & * \\
\hline 5139.4557 & $*$ & & & 7049.8399 & & * & & 4911.2825 & & & $*$ \\
\hline 5980.8690 & * & & & 7326.6056 & & * & & 5192.1339 & & & $=$ \\
\hline 6735.3584 & * & & & 7480.0988 & & * & & 5851.6479 & & & * \\
\hline 6899.1073 & F & & & 8523.2175 & & * & & 6303.8039 & & & $*$ \\
\hline 9139.0924 & $x$ & & & 9634.4022 & & $*$ & & 6796.2430 & & & $*$ \\
\hline \multirow[t]{4}{*}{10272.3884} & & & & \multirow{4}{*}{$\begin{array}{l}\text { M1A } \\
\text { M1B } \\
\text { M1C }\end{array}$} & & & & 7231.7864 & & & $*$ \\
\hline & & & & & & & & 7405.0406 & & & $*$ \\
\hline & & & & & & & & 8187.5522 & & & $*$ \\
\hline & & & & & & & & 9293.7849 & & & $*$ \\
\hline
\end{tabular}


Figura 42 - Espectros peptídicos normalizados e perfis eletroforéticos das cepas isoladas a partir do cultivo de M1A-S. O cultivo continha duas cepas distintas, M1AS-1 e M1AS-2.

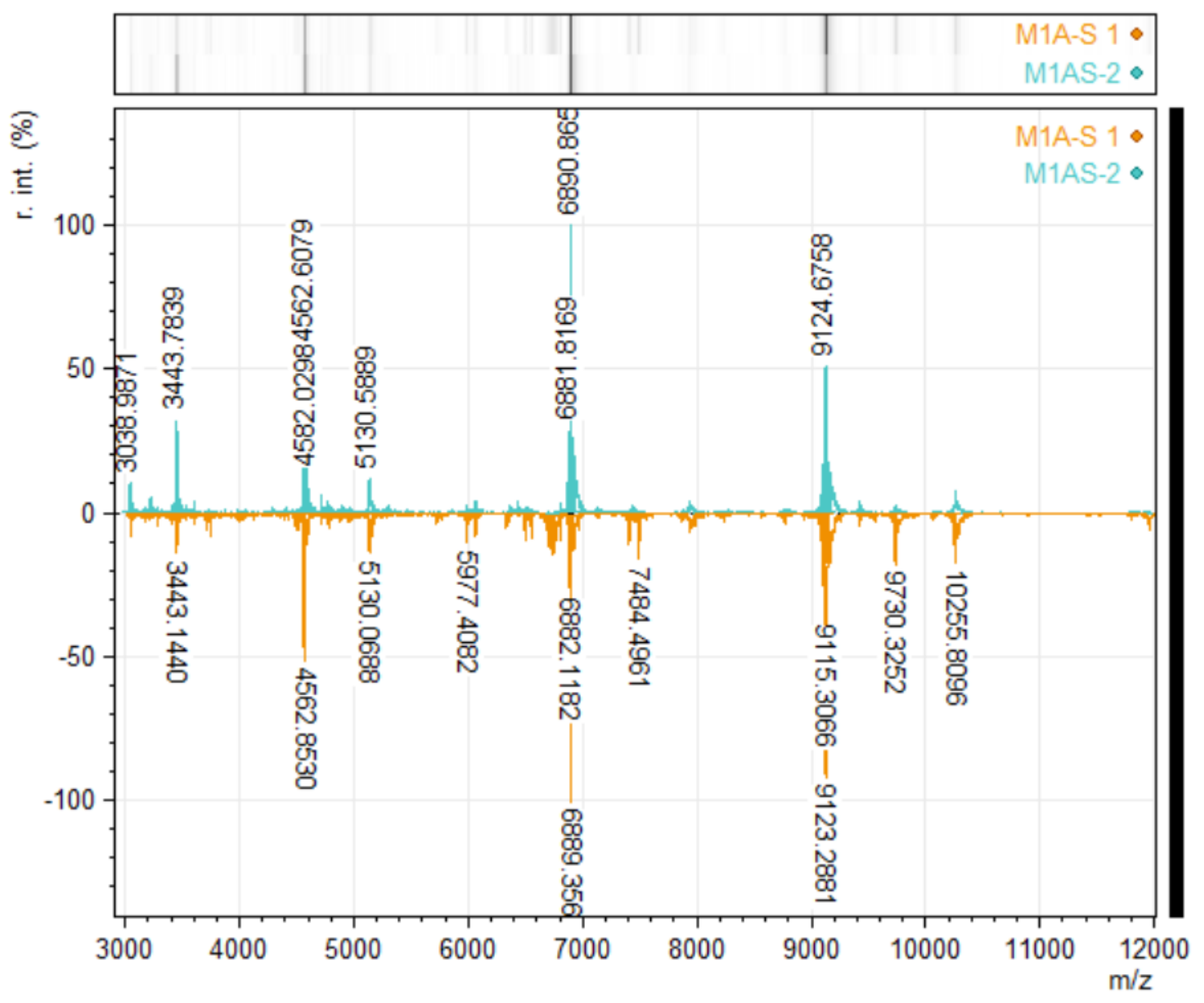


APÊNDICE C - Velocidades máximas de crescimento de M1B-S sob diferentes condições de cultivo

Figura 43 - Curvas de crescimento a diferentes concentrações de $\mathrm{CO}_{2}(1 \mathrm{~atm})$ ajustadas pelos modelos Gompertz Modificado, Logístico Modificado, Potência Modificado e linear.

Regressão linear fase exponencial $\left(20 \% \mathrm{CO}_{2}\right)$

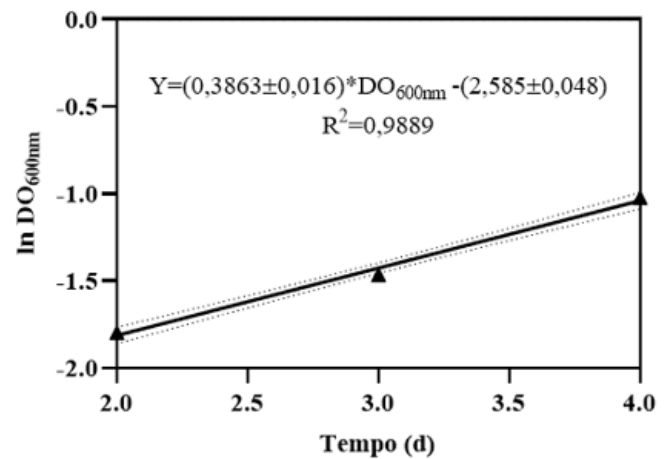

Regressão não-linear $\left(20 \% \mathrm{CO}_{2}\right)$

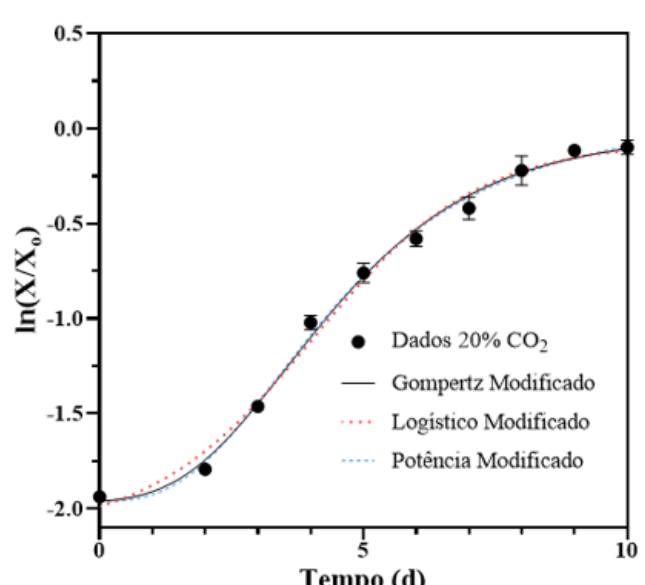

Regressão linear fase exponencial $\left(10 \% \mathrm{CO}_{2}\right)$

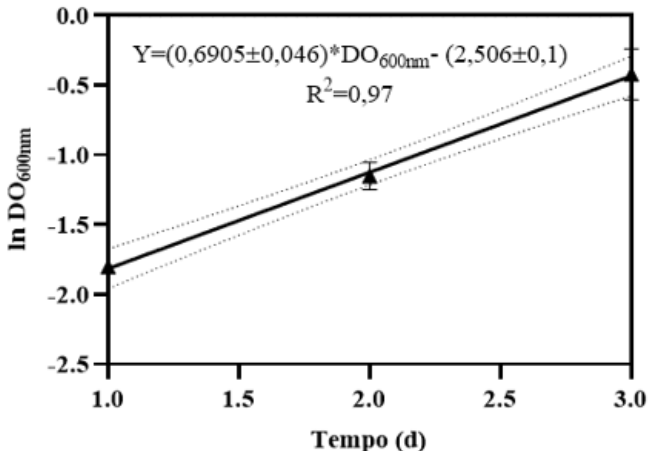

Regressão não-linear $\left(10 \% \mathrm{CO}_{2}\right)$

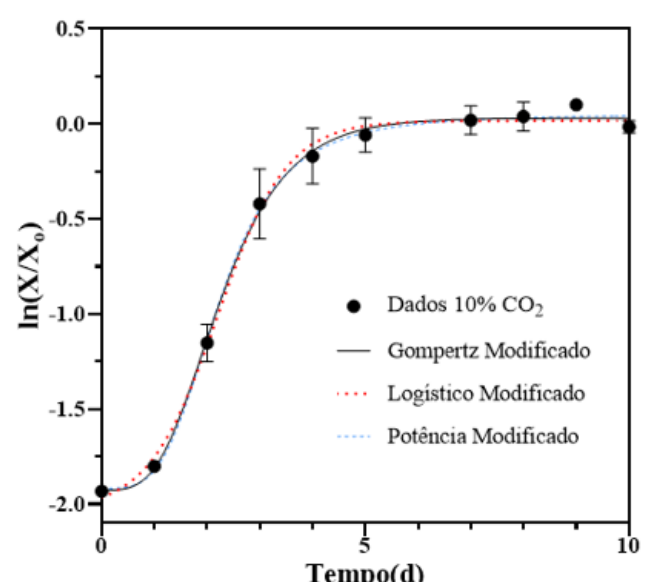

Regressão linear fase exponencial $\left(5 \% \mathrm{CO}_{2}\right)$

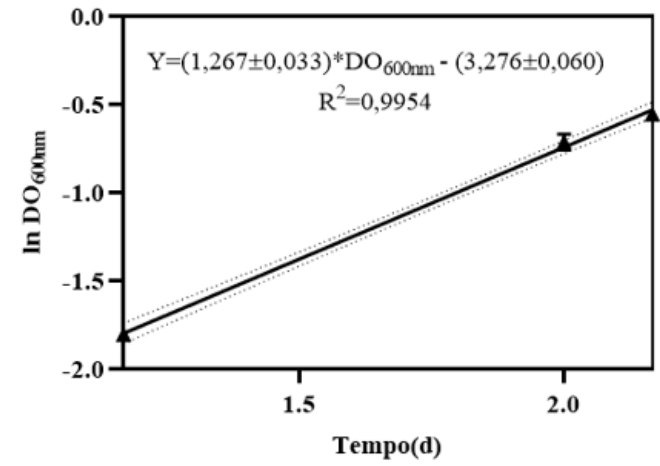

Regressão não-linear ( $\left.5 \% \mathrm{CO}_{2}\right)$

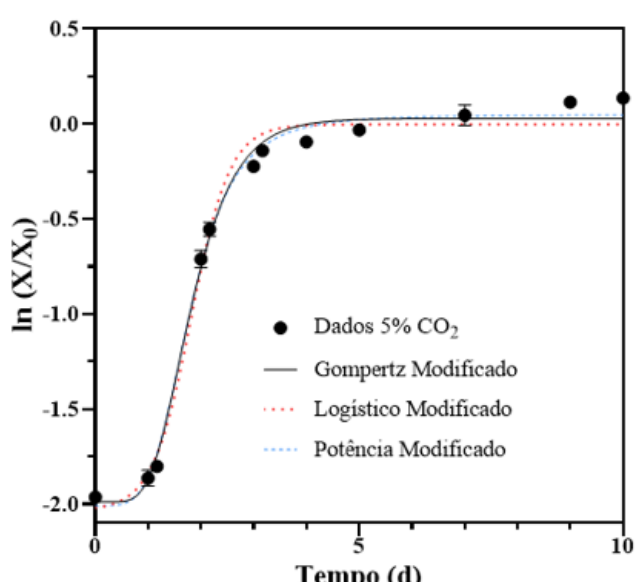


Figura 44 - Curvas de crescimento a diferentes temperaturas ajustadas pelos modelos Gompertz Modificado, Logístico Modificado, Potência Modificado e linear.

Regressão linear fase exponencial $\left(30^{\circ} \mathrm{C}\right)$

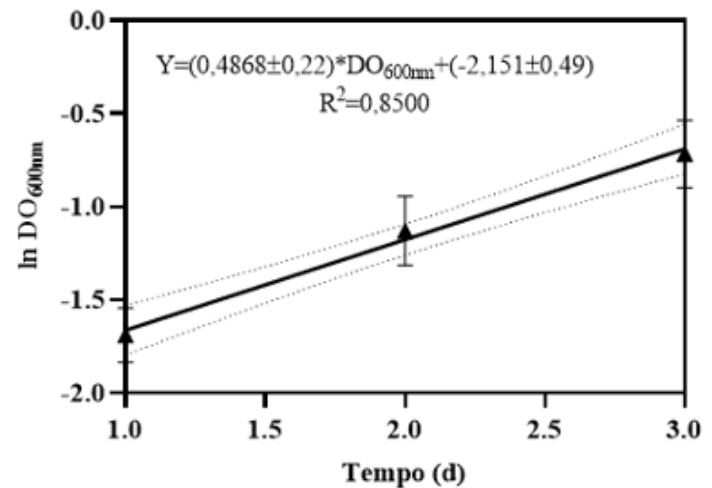

Regressão não-linear $\left(30^{\circ} \mathrm{C}\right)$

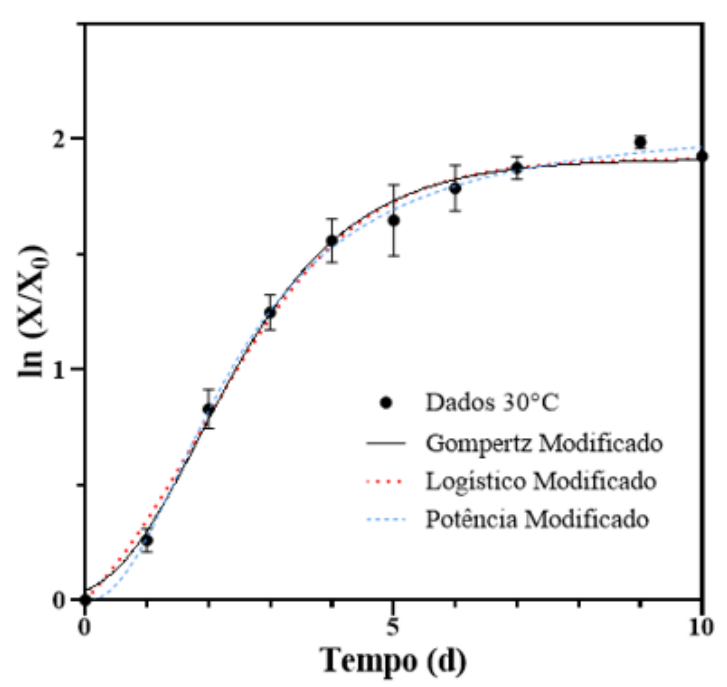

Regressão linear fase exponencial $\left(40^{\circ} \mathrm{C}\right)$

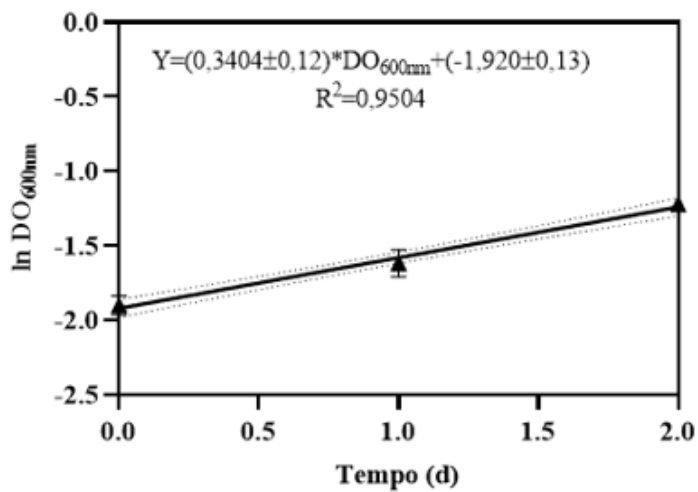

Regressão não-linear $\left(40^{\circ} \mathrm{C}\right)$

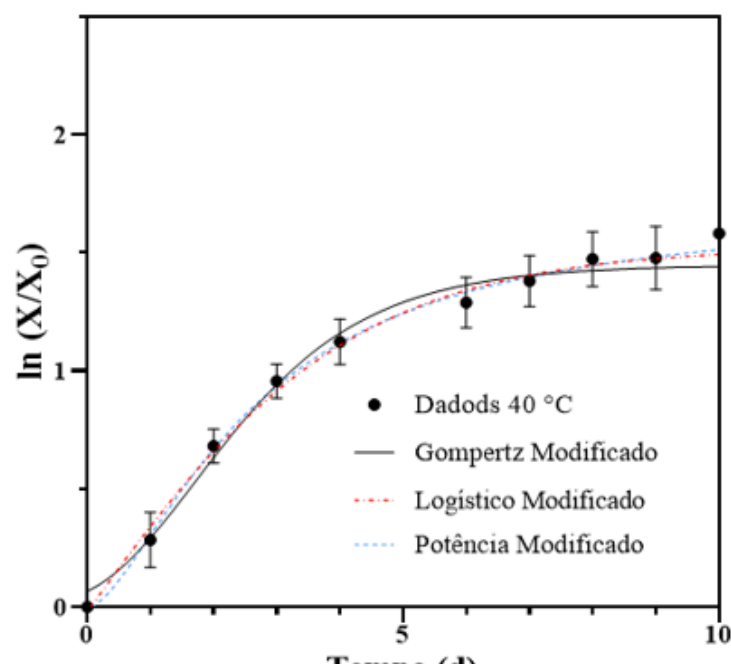

Tempo (d)
Regressão linear fase exponencial $\left(50^{\circ} \mathrm{C}\right)$

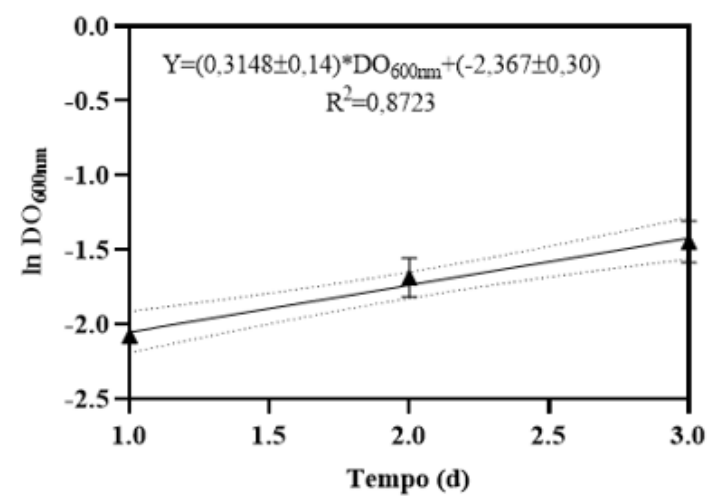

Regressão não-linear $\left(50^{\circ} \mathrm{C}\right)$

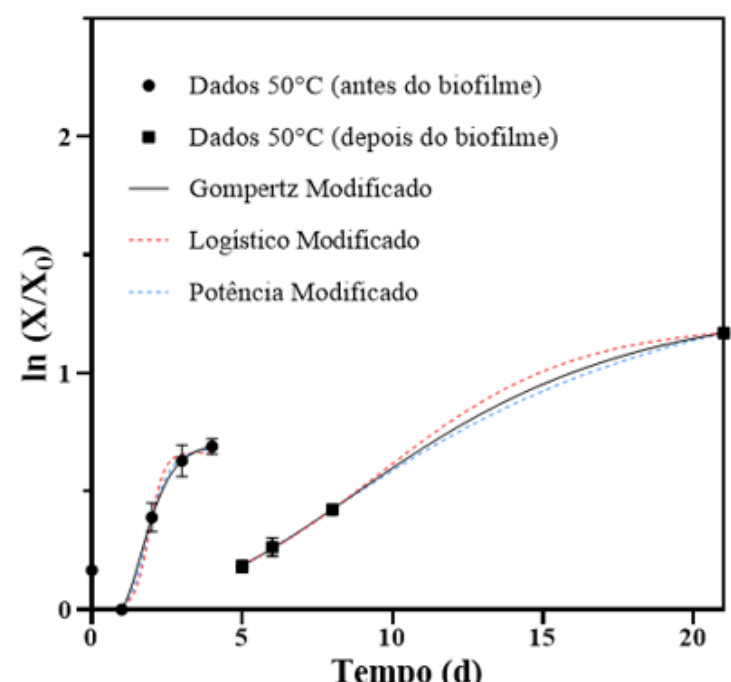


Figura 45 - Velocidades máximas de crescimento $\left(\mu_{\text {máx }}\right)$ obtidas para a cepa M1B-S quando cultivada sob diferentes concentrações de $\mathrm{CO}_{2}\left(5 \%, 10 \%\right.$ e $\left.20 \% \mathrm{CO}_{2}\right)$.

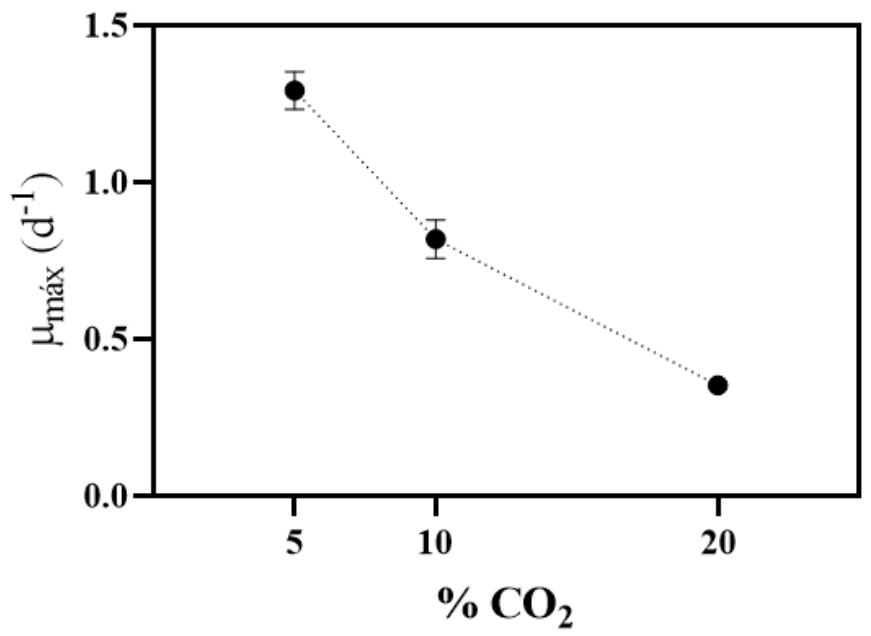

Figura 46 - Velocidades máximas de crescimento $\left(\mu_{\text {máx }}\right)$ obtidas para a cepa M1B-S quando cultivada a $10 \% \mathrm{CO}_{2}(1 \mathrm{~atm})$ e sob diferentes temperaturas $\left(30^{\circ} \mathrm{C}, 40^{\circ} \mathrm{C}\right.$ e $\left.50^{\circ} \mathrm{C}\right)$.

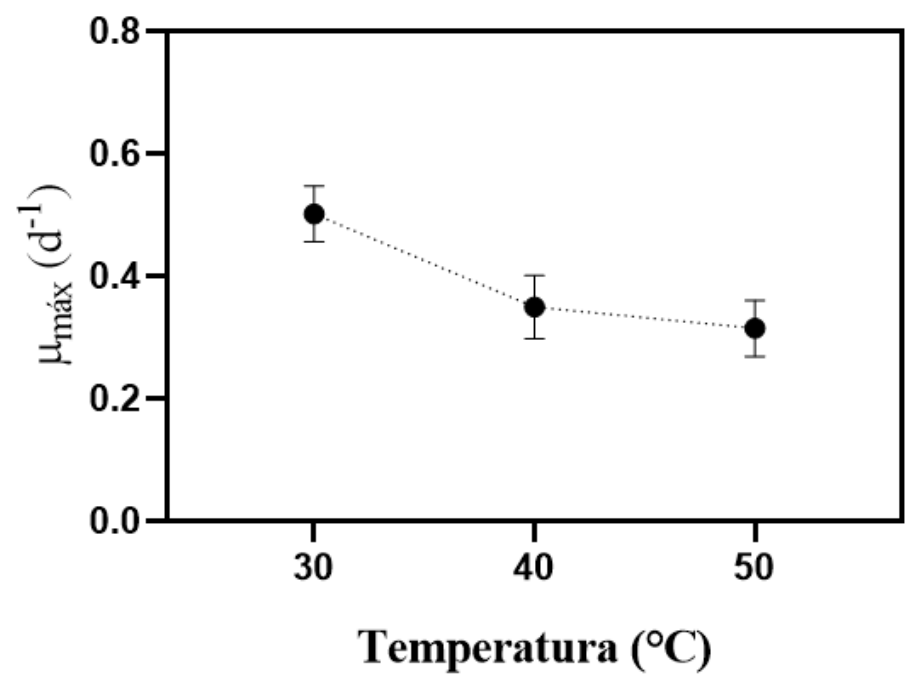


Tabela 17 - Teste de comparação múltipla Games-Howell entre as velocidades específicas máximas de crescimento $\left(\mu_{\text {máx }}\right)$ a diferentes concentrações de $\mathrm{CO}_{2}$.

\begin{tabular}{cccc}
\hline Comparação $\boldsymbol{\mu}_{\text {máx }}$ & $\begin{array}{c}\text { Diferença } \\
\text { média }\end{array}$ & $\begin{array}{c}\text { Intervalo de confiança (95\%) } \\
\text { da diferença }\end{array}$ & Significante $(\mathbf{p}<\mathbf{0 , 0 5})$ \\
\hline $5 \%$ vs. $10 \%$ & 0,4739 & $0,4358-0,5120$ & $\operatorname{Sim}(\mathrm{p}<0,0001)$ \\
$5 \%$ vs. $20 \%$ & 0,9409 & $0,9143-0,9675$ & $\operatorname{Sim}(\mathrm{p}<0,0001)$ \\
$10 \%$ vs. $20 \%$ & 0,4670 & $0,4368-0,4972$ & $\operatorname{Sim}(\mathrm{p}<0,0001)$ \\
\hline
\end{tabular}

Tabela 18 - Teste de comparação múltipla Games-Howell entre as velocidades específicas máximas de crescimento $\left(\mu_{\text {máx }}\right)$ a diferentes temperaturas.

\begin{tabular}{cccc}
\hline Comparação $\boldsymbol{\mu}_{\text {máx }}$ & $\begin{array}{c}\text { Diferença } \\
\text { média }\end{array}$ & $\begin{array}{c}\text { Intervalo de confiança (95\%) } \\
\text { da diferença }\end{array}$ & Significante $(\mathbf{p}<\mathbf{0 , 0 5})$ \\
\hline $30^{\circ} \mathrm{C}$ vs. $40^{\circ} \mathrm{C}$ & 0,1878 & $0,05805-0,3175$ & $\operatorname{Sim}(\mathrm{p}=0,0025)$ \\
$30^{\circ} \mathrm{C}$ vs. $50^{\circ} \mathrm{C}$ & 0,1995 & $0,05139-0,3476$ & $\operatorname{Sim}(\mathrm{p}=0,0055)$ \\
$40^{\circ} \mathrm{C}$ vs. $50^{\circ} \mathrm{C}$ & 0,01171 & $-0,09961-0,1230$ & Não $(\mathrm{p}=0,9636)$ \\
\hline
\end{tabular}


APÊNDICE D - Variação do pH nos cultivos cepa M1B-S

Figura 47 - Variação no pH do meio de cultura durante o crescimento da cepa M1B-S sob $10 \% \mathrm{CO}_{2}$

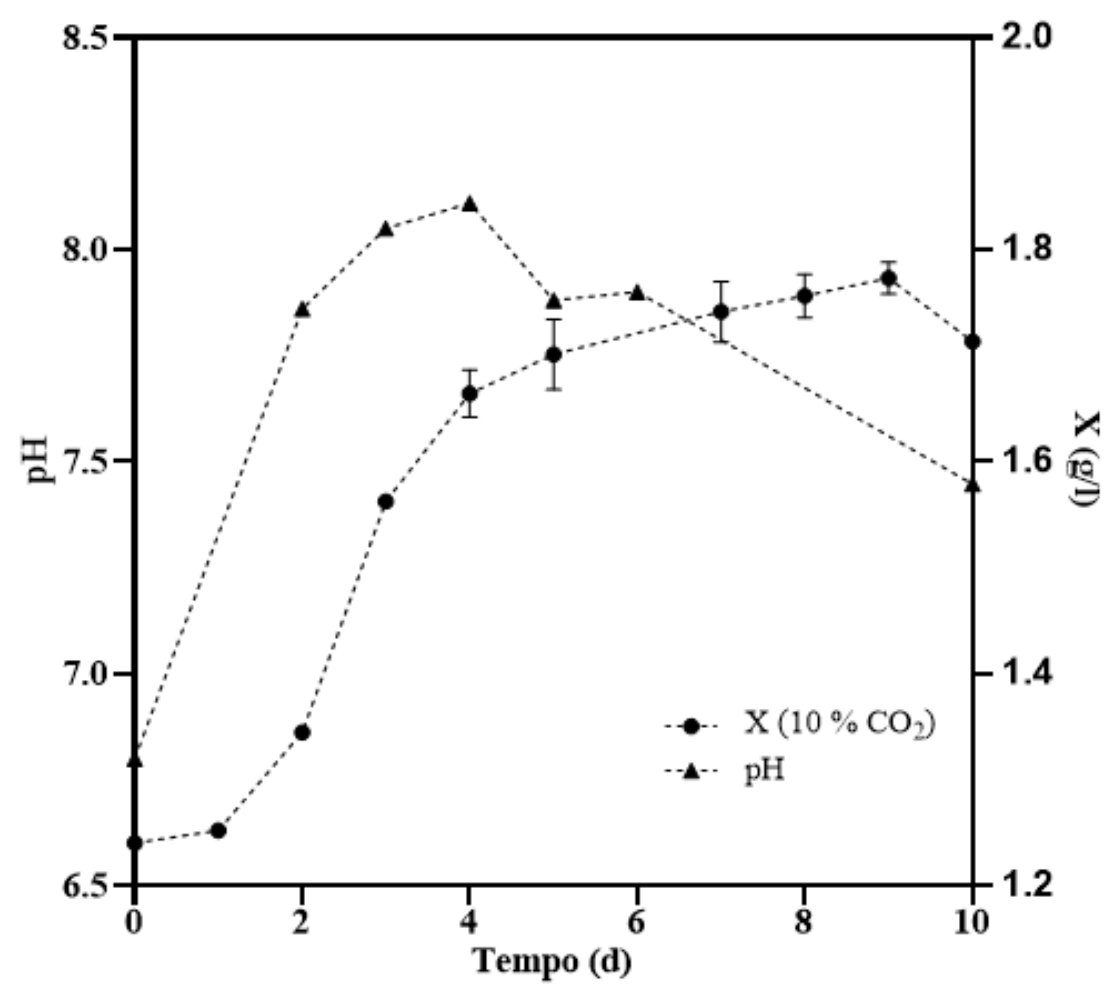


APÊNDICE E - Resultados das análises de concentração de íons $\mathrm{NO}_{3}{ }^{-}{\mathrm{e} \mathrm{NO}_{2}}^{-}$nos cultivos de M1B-S sob $20 \% \mathrm{CO}_{2}$

Figura 48 - Resultados dos testes colorimétricos para a detecção de íons $\mathrm{NO}_{3}{ }^{-}{\mathrm{e} \mathrm{NO}_{2}}^{-}$no meio de cultua da bactéria M1B-S. a) Concentração aproximadamente nula de íons $\mathrm{NO}_{3}{ }^{-}$ao final do $8^{\circ}$ dia de incubação sob $20 \% \mathrm{CO}_{2}$ (concentração inicial de $\mathrm{NO}_{3}{ }^{-}$igual à $1,31 \mathrm{~g} / \mathrm{L}$ ). b) e c) concentração de íons $\mathrm{NO}_{2}{ }^{-}$no $4^{\circ}$ e $5^{\circ}$ dias de incubação sob $20 \% \mathrm{CO}_{2}$ (concentração inicial de $\mathrm{NO}_{2}{ }^{-}$era nula).

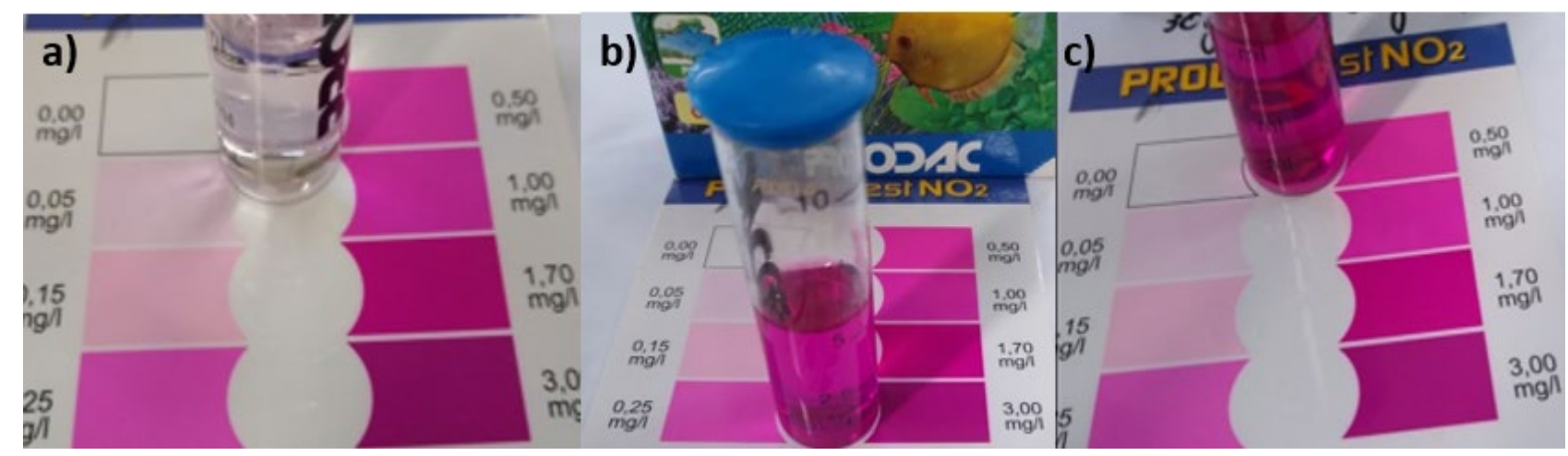


APÊNDICE F - Sequência parcial do gene 16S rRNA (16S rDNA) da cepa M1B-S

TCCTGGCTCAGATTGAACGCTGGCGGCAGGCCTAACACATGCAAGTCGAGCGGAAACGATGGGAGCTTGCTC CCAGGCGTCGAGCGGCGGACGGGTGAGTAACACGTGGGAATCTGCCCATTAGTGGGGGATAACTCGGGGAA ACTCGAGCTAATACCGCATAATCCCTACGGGGGAAAGCAGGGGATCTTCGGACCTTGCGCTGATGGATGAGC CCGCGTCGGATTAGCTTGTTGGTGGGGTAATGGCCCACCAAGGCGACGATCCGTAACTGGTCTGAGAGGATG GCCAGTCACACCGGGACTGAGACACGGCCCGGACTCCTACGGGAGGCAGCAGTGGGGAATCTTGGACAATG GGCGCAAGCCTGATCCAGCCATGCCGCGTGTGTGAAGAAGGCCTTCGGGTTGTAAAGCACTTTCAGTAGGGA GGAAGGCTTTGGGCTAATACCCTGGAGTACTTGACGTTACCTACAGAAGAAGCACCGGCTAATTTCGTGCCAG CAGCCGCGGTAATACGAAAGGTGCGAGCGTTAATCGGAATTACTGGGCGTAAAGCGCGCGTAGGCGGTGTGT TAAGTCGGATGTGAAAGCCCAGGGCTCAACCTTGGAATTGCATCCGATACTGGCACGCTAGAGTGCAGTAGA GGGAGGTGGAATTTCCGGTGTAGCGGTGAAATGCGTAGAGATCGGAAGGAACACCAGTGGCGAAGGCGGCC TCCTGGACTGACACTGACGCTGAGGTGCGAAAGCGTGGGGAGCAAACAGGATTAGATACCCTGGTAGTCCAC GCCGTAAACGATGTCTACTAGCCGTTGGGGTCCTTAGTGACTTTGGTGGCGCAGCTAACGCGATAAGTAGACC GCCTGGGGAGTACGGCCGCAAGGTTAAAACTCAAATGAATTGACGGGGGCCCGCACAAGCGGTGGAGCATG TGGTTTAATTCGATGCAACGCGAAGAACCTTACCAGGCCTTGACATCCTGCGAACTTTCTAGAGATAGATTGGT GCCTTCGGGAGCGCAGTGACAGGTGCTGCATGGCTGTCGTCAGCTCGTGTCGTGAGATGTTGGGTTAAGTCCC GTAACGAGCGCAACCCTTGTCCTTAGTTGCCAGCACTTCGGGTGGGAACTCTAGGGAGACTGCCGGTGACAAA CCGGAGGAAGGTGGGGACGACGTCAAGTCATCATGGCCCTTACGGCCTGGGCTACACACGTGCTACAATGGT TGGTACAGAGGGTTGCGAAGTCGCGAGGCGGAGCTAATCTCTCAAAGCCAATCGTAGTCCGGATTGGAGTCT GCAACTCGACTCCATGAAGTCGGAATCGCTAGTAATCGCGGATCAGAATGCCGCGGTGAATACGTTCCCGGGC CTTGTACACACCGCCCGTCACACCATGGGAGTGGATTGCACCAGAAGTAGTTAGTCTAACCTTCGGGAGGACG ATTACCACGGTGTGGTTCATGACTGGGGTGAAGTCGTAACAAGGTAA 